In cooperation with the Wind River Environmental Quality Commission

\title{
Assessment of the Quality of Groundwater and the Little Wind River in the Area of a Former Uranium Processing Facility on the Wind River Reservation, Wyoming, 1987 through 2010
}

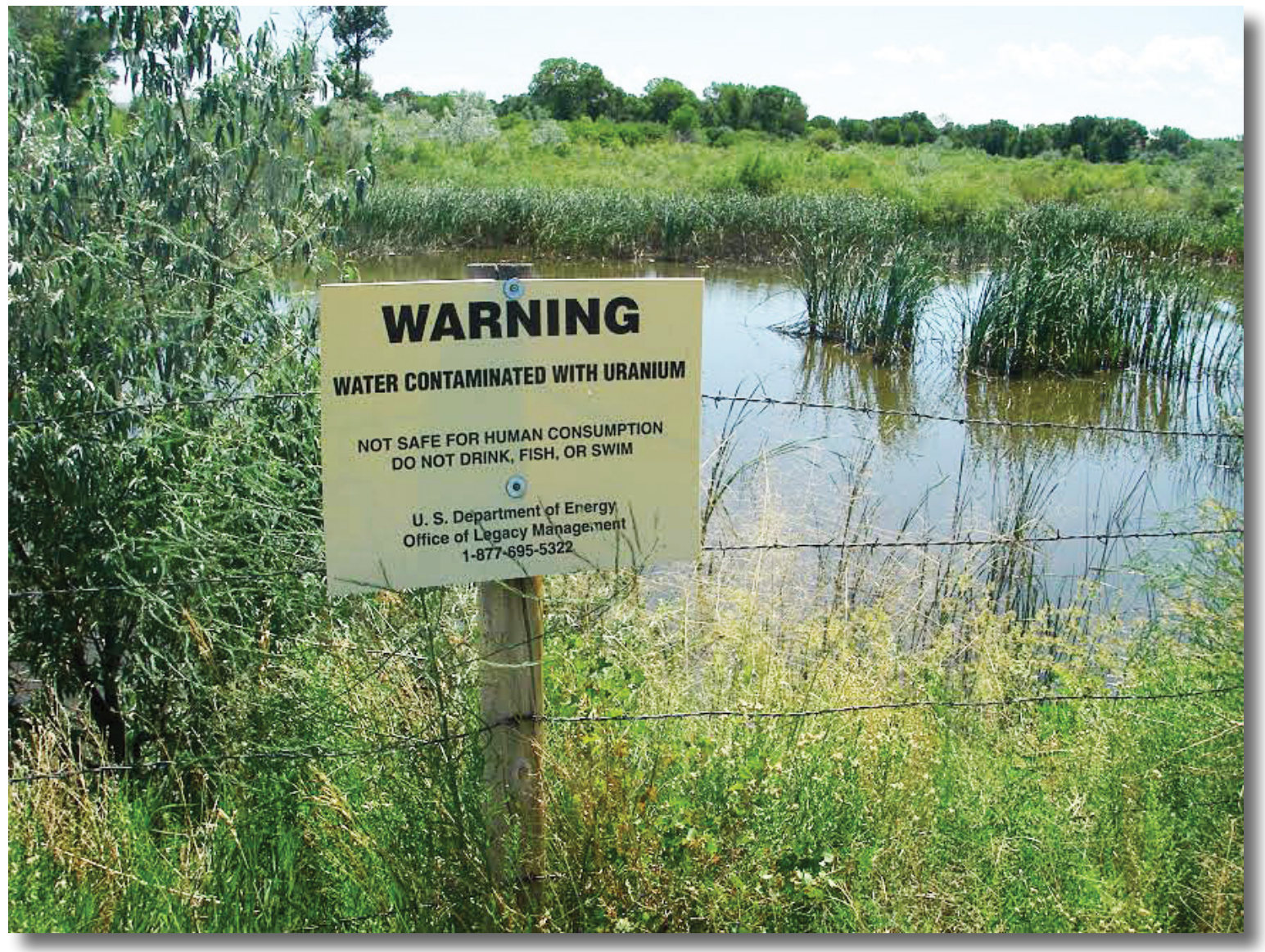

Scientific Investigations Report 2013-5218 
Cover. Oxbow lake on Little Wind River near Riverton, Wyoming. Photo taken by Mike Sweat, Wyoming Water Science Center, in 2012. 


\section{Assessment of the Quality of Groundwater and the Little Wind River in the Area of a Former Uranium Processing Facility on the Wind River Reservation, Wyoming, 1987 through 2010}

By Anthony J. Ranalli and David L. Naftz

In cooperation with the Wind River Environmental Quality Commission

Scientific Investigations Report 2013-5218 


\title{
U.S. Department of the Interior SALLY JEWELL, Secretary
}

\section{U.S. Geological Survey \\ Suzette M. Kimball, Acting Director}

\author{
U.S. Geological Survey, Reston, Virginia: 2014
}

For more information on the USGS - the Federal source for science about the Earth, its natural and living resources, natural hazards, and the environment, visit http://www.usgs.gov or call 1-888-ASK-USGS.

For an overview of USGS information products, including maps, imagery, and publications, visit http://Www.usgs.gov/pubprod

To order this and other USGS information products, visit http://store.usgs.gov

Any use of trade, firm, or product names is for descriptive purposes only and does not imply endorsement by the U.S. Government.

Although this information product, for the most part, is in the public domain, it also may contain copyrighted materials as noted in the text. Permission to reproduce copyrighted items must be secured from the copyright owner.

Suggested citation:

Ranalli, A.J., and Naftz, D.L., 2014, Assessment of the quality of groundwater and the Little Wind River in the area of a former uranium processing facility on the Wind River Reservation, Wyoming, 1987 through 2010: U.S. Geological Survey Scientific Investigations Report 2013-5218, 104 p., http://dx. doi.org/10.3133/sir20135218.

ISSN 2328-0328 (online) 


\section{Contents}

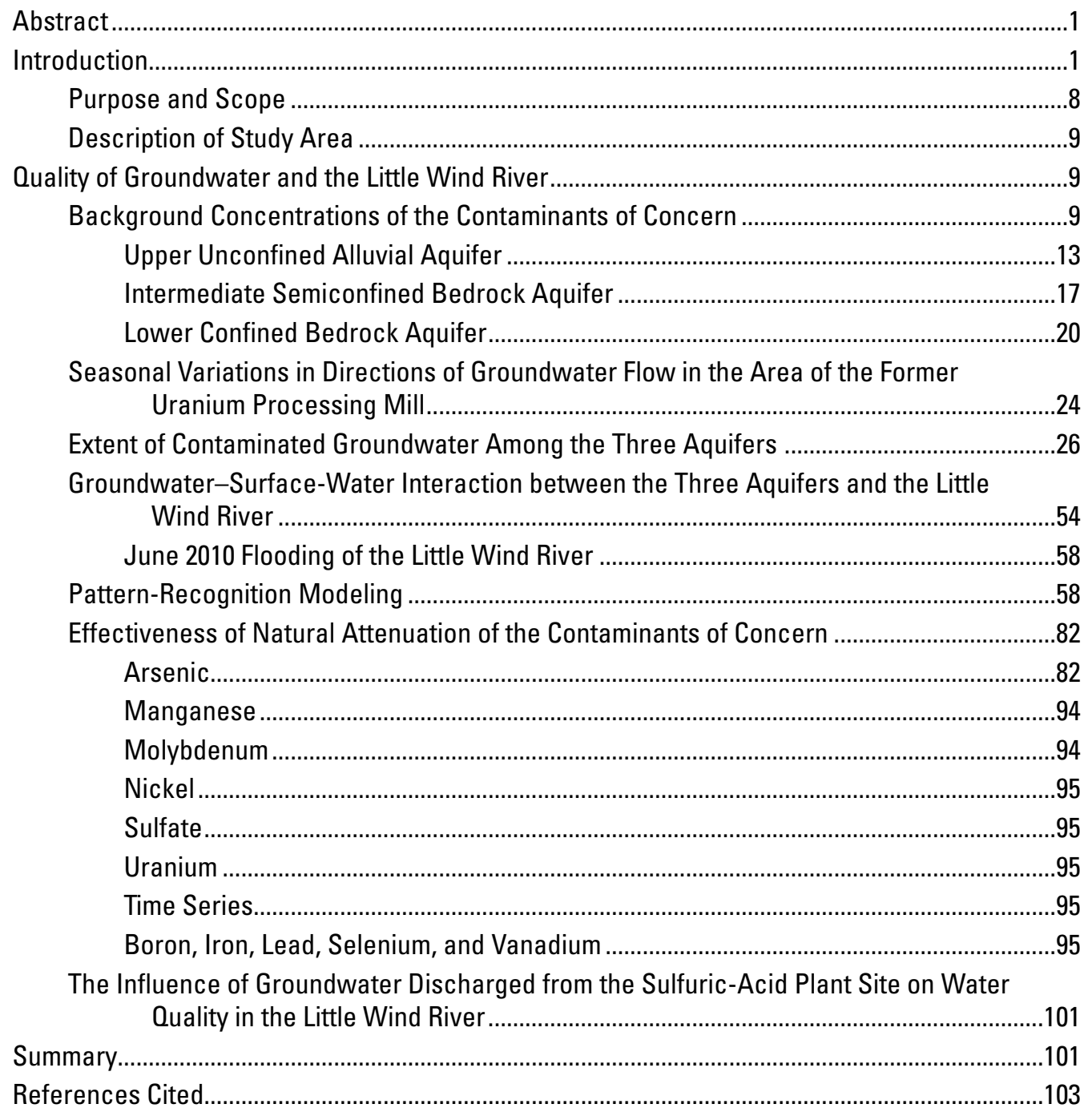




\section{Figures}

1. Location of the Riverton Uranium Mill Tailings Remedial Action site, Riverton, Wyoming.

2. Location of the U.S. Department of Energy groundwater monitoring wells (blue circles); abandoned groundwater monitoring wells (red circles), and surface-water monitoring sites (triangles) on the Uranium Mill Tailings Remedial Action site on the Wind River Indian Reservation, Wyoming

3. Geologic cross section of the Riverton Uranium Mill Tailings Remedial Action site on the Wind River Indian Reservation.

4. Hydraulic-head elevation and generalized flow directions in the upper unconfined alluvial aquifer.

5. Conceptual hydrologic model of the Uranium Mill Tailings Remedial Action site............8

6. Average major ion chemistry in the upper unconfined alluvial aquifer .........................13

7. Boxplots of $A, \mathrm{pH} ; B$, specific conductance; and $C$, sulfate in the upper unconfined

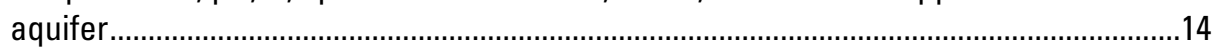

8. Average major ion chemistry in the semiconfined bedrock aquifer..............................17

9. Boxplots of $A, \mathrm{pH} ; B$, specific conductance; and $C$, sulfate in the intermediate semiconfined bedrock aquifer.

10. Average major ion chemistry in the lower confined bedrock aquifer .............................21

11. Boxplots of $A, \mathrm{pH} ; B$, specific conductance; and $C$, sulfate in the lower confined bedrock aquifer...

12. Hydrograph of groundwater elevation for U.S. Department of Energy wells 710, 101, $728,716,722 R$, and 707 for the period of record

13. Boxplots of $A$, dissolved uranium and $B$, sulfate concentrations in U.S. Department of Energy wells 710, 711, and 101 for the period of record

14. Hydrograph of DOE wells $710,101,716,707$, and 789 based on pressure transducer data

15. Hydrographs of groundwater elevation for nested U.S. Department of Energy monitoring wells for the period of record: $A$, Wells $724,725,726,101,111,110,784$, and 732; $B$, Wells 716, 717, 722R, 723, 707,705, and 709; $C$, Wells 706, 735, 718, 719, 729 , and 730 ; and $D$, Wells $720,721,733$, and 734 .

16. Average major ion chemistry for nested U.S. Department of Energy groundwater wells 724,725 , and 726 .

17. Average major ion chemistry for nested U.S. Department of Energy groundwater wells 101, 110, and 111 .

18. Average major ion chemistry for nested U.S. Department of Energy groundwater wells 716 and 717

19. Average major ion chemistry for nested U.S. Department of Energy groundwater wells 707,705 , and 709 .

20. Average major ion chemistry for nested U.S. Department of Energy groundwater wells 706 and 735 ......

21. Average major ion chemistry for nested U.S. Department of Energy groundwater wells 718 and 719

22. Average major ion chemistry for nested U.S. Department of Energy groundwater wells 729 and 730

23. Average major ion chemistry for nested U.S. Department of Energy groundwater wells 720 and 721 
24. Average major ion chemistry for nested U.S. Department of Energy groundwater wells 733 and 734 .....

25. Median concentrations of manganese in nested U.S. Department of Energy groundwater wells.

26. Median concentrations of molybdenum in nested U.S. Department of Energy groundwater wells.

27. Median concentrations of sulfate in nested U.S. Department of Energy groundwater wells.

28. Median concentrations of uranium in nested U.S. Department of Energy groundwater wells.

29. Graphs comparing the response in water elevations from monitoring wells completed in the different aquifers to river stage (discharge) in areas $A$, north and $B$, south of the Little Wind River, Riverton, Wyoming, Uranium Mill Tailings Remedial Action site study area

30. A, Comparison of water elevations in monitor wells completed in the intermediate semiconfined bedrock aquifer to the daily mean discharge in Little Wind River near Riverton, Wyoming. $B$, Schematic diagram of changes in seasonal water-elevation levels (dashed red and blue lines) in the intermediate semiconfined bedrock aquifer.

31. Effects of the June 2010 flooding of the Little Wind River on the concentration of $A$, manganese; $B$, molybdenum; $C$, sulfate; and $D$, uranium in selected U.S.

Department of Energy wells in the upper unconfined alluvial aquifer

32. Loading values and associated chemical constituent for principal-components-analysis $A$, factors 1 and 2 and $B$, factors 1 and 3 , Riverton, Wyoming, Uranium Mill Tailings Remedial Action Project monitoring data.....

33. Scatter plots comparing factor 1 and factor 2 scores determined by principal-components analysis of 529 water samples collected from the Riverton, Wyoming, Uranium Mill Tailings Remedial Action site from April 1993 through November 2011. Factor scores are differentiated by aquifer. $A$, Confined aquifer samples; $B$, unconfined aquifer samples; and $C$, semiconfined aquifer samples. Dashed lines outline samples that likely have a geochemical signature associated with contamination

34. Location of wells completed in the unconfined aquifer with factor 1 scores less than 10 (blue) and factor 2 scores greater than 12 (yellow), Riverton, Wyoming, Uranium Mill Tailings Remedial Action site.

35. Location of wells completed in the semiconfined aquifer with factor 2 scores greater than 12.5 (yellow), Riverton Wyoming, Uranium Mill Tailings Remedial Action site

36. Scatter plots showing temporal trends in factor 1 and factor 2 scores for water samples collected from the unconfined aquifer from 1993 through 2011, Riverton, Wyoming, Uranium Mill Tailings Remedial Action site.

37. $A$, Water elevation in selected wells completed in the unconfined aquifer compared to $B$, annual mean (1993-2011) and mean annual discharge (1941-2011) in the Little Wind River near Riverton, Wyoming, stream gage (USGS 06235500)

38. Scatter plots comparing factor 1 and factor 2 scores determined by principal components analysis for 116 surface-water samples collected from the Riverton, Wyoming, Uranium Mill Tailings Remedial Action site from April 1993 through November 2011. Samples falling inside the dashed line are likely not associated with contamination. Number adjacent to each symbol designates the surface-water sample site 
39. Location of surface-water monitoring sites at the Riverton, Wyoming, Uranium Mill Tailings Remedial Action site.

40. Median concentrations of $A$, arsenic and $B$, comparison of arsenic concentrations in the upper unconfined alluvial aquifer and the intermediate semiconfined bedrock aquifer at two locations

41. Concentrations of $A$, manganese, $B$, molybdenum, $C$, nickel, $D$, sulfate, and $E$, uranium in the upper unconfined alluvial aquifer throughout the UMTRA site ...

42. A, Time-series plots of the concentration of manganese along on an east-west axis through the Uranium Mill Tailings Remedial Action (UMTRA) site. B, Time-series plots of the concentration of molybdenum along on an east-west axis through the UMTRA site. $C$, Time-series plots of the concentration of sulfate along on an east-west axis through the UMTRA site. $D$, Time-series plots of the concentration of uranium along on an east-west axis through the UMTRA site.

43. Time-series plots of the concentration of dissolved manganese, molybdenum, sulfate, and uranium in the Koch drainage ditch and West Side Creek.

\section{Tables}

1. State of Wyoming agricultural and U.S. Environmental Protection Agency groundwater-quality standards

2. Saturation indices for dissolved arsenic, boron, lead, manganese, mercury, molybdenum, nickel, selenium, uranium, and vanadium data in the upper unconfined alluvial aquifer.

3. Summary of dissolved arsenic, boron, lead, manganese, mercury, molybdenum, nickel, selenium, uranium, and vanadium concentration data in the upper unconfined alluvial aquifer.

4. Summary of dissolved arsenic, boron, lead, manganese, mercury, molybdenum, nickel, selenium, uranium, and vanadium concentration data in the intermediate semiconfined bedrock aquifer

5. Summary of dissolved arsenic, boron, lead, manganese, mercury, molybdenum, nickel, selenium, uranium, and vanadium concentration data in the lower confined bedrock aquifer

6. Water-quality data used in pattern-recognition analysis of Riverton, Wyoming, Uranium Mill Tailings Remedial Action (UMTRA) site

7. Concentration of arsenic, molybdenum, nickel, and uranium measured in unfiltered samples collected from domestic well 445

8. Summary of the available iron, lead, selenium, and vanadium concentration data in U.S. Department of Energy wells in the contaminated groundwater plume in the upper unconfined alluvial aquifer

9. Summary of the available iron, lead, selenium, and vanadium concentration data in U.S. Department of Energy wells in the contaminated groundwater plume in the intermediate semiconfined bedrock aquifer. 


\section{Conversion Factors}

Inch/Pound to SI

\begin{tabular}{|c|c|c|}
\hline Multiply & By & To obtain \\
\hline \multicolumn{3}{|c|}{ Length } \\
\hline foot $(\mathrm{ft})$ & 0.3048 & meter $(\mathrm{m})$ \\
\hline mile (mi) & 1.609 & kilometer $(\mathrm{km})$ \\
\hline \multicolumn{3}{|c|}{ Area } \\
\hline acre & & hectare \\
\hline hectare (ha) & 0.003861 & square mile $\left(\mathrm{mi}^{2}\right)$ \\
\hline \multicolumn{3}{|c|}{ Volume } \\
\hline liter $(\mathrm{L})$ & 0.2642 & gallon (gal) \\
\hline cubic yard $\left(\mathrm{yd}^{3}\right)$ & 0.7646 & cubic meter \\
\hline \multicolumn{3}{|c|}{ Flow rate } \\
\hline cubic foot per second $\left(\mathrm{ft}^{3} / \mathrm{s}\right)$ & 0.02832 & cubic meter per second $\left(\mathrm{m}^{3} / \mathrm{s}\right)$ \\
\hline \multicolumn{3}{|c|}{ Mass } \\
\hline kilogram (kg) & 2.205 & pound avoirdupois (lb) \\
\hline
\end{tabular}

Temperature in degrees Celsius $\left({ }^{\circ} \mathrm{C}\right)$ may be converted to degrees Fahrenheit $\left({ }^{\circ} \mathrm{F}\right)$ as follows:

${ }^{\circ} \mathrm{F}=\left(1.8 \times{ }^{\circ} \mathrm{C}\right)+32$

Temperature in degrees Fahrenheit $\left({ }^{\circ} \mathrm{F}\right)$ may be converted to degrees Celsius $\left({ }^{\circ} \mathrm{C}\right)$ as follows:

${ }^{\circ} \mathrm{C}=\left({ }^{\circ} \mathrm{F}-32\right) / 1.8$

Vertical coordinate information is referenced to the North American Vertical Datum of 1988

(NAVD 88)

Horizontal coordinate information is referenced to the North American Datum of 1983 (NAD 83)

In this report "sea level" refers to the National Geodetic Vertical Datum of 1929 (NGVD of 1929)-A geodetic datum derived from a general adjustment of the first-order level nets of both the United States and Canada, formerly called Sea Level Datum of 1929.

Concentrations of chemical constituents in water are given either in milligrams per liter ( $\mathrm{mg} / \mathrm{L}$ ) or micrograms per liter $(\mu \mathrm{g} / \mathrm{L})$.

Specific conductance is given in microsiemens per centimeter at 25 degrees Celsius $(\mu \mathrm{S} / \mathrm{cm}$ at $\left.25^{\circ} \mathrm{C}\right)$.

Water Year (WY) is defined as beginning October 1 and continuing through September 30 of the following year. 


\title{
Acronyms and Initialisms
}

\author{
CFR Code of Federal Regulations \\ COC contaminant of concern \\ COPC contaminant of potential concern \\ DOE U.S. Department of Energy \\ EPA U.S. Environmental Protection Agency \\ GEMS Geospatial Environmental Mapping System \\ LRL lower reporting limit \\ MCL maximum contaminant level \\ ORP oxidation reduction potential \\ PCA principal component analysis \\ TU tritium units \\ UMTRA Uranium Mill Tailings Remedial Action \\ USGS U.S. Geological Survey \\ WREOC Wind River Environmental Quality Commission
}




\title{
Assessment of the Quality of Groundwater and the Little Wind River in the Area of a Former Uranium Processing Facility on the Wind River Reservation, Wyoming, 1987 through 2010
}

\author{
By Anthony J. Ranalli and David L. Naftz
}

\section{Abstract}

In 2010, the U.S Geological Survey (USGS), in cooperation with the Wind River Environmental Quality Commission (WREQC), began an assessment of the effectiveness of the existing monitoring network at the Riverton, Wyoming, Uranium Mill Tailings Remedial Action (UMTRA) site. The USGS used existing data supplied by the U.S. Department of Energy (DOE). The study was to determine (1) seasonal variations in the direction of groundwater flow in the area of the former uranium processing facility toward the Little Wind River, (2) the extent of contaminated groundwater among the aquifers and between the aquifers and the Little Wind River, (3) whether current monitoring is adequate to establish the effectiveness of natural attenuation for the contaminants of concern, and (4) the influence of groundwater discharged from the sulfuric-acid plant on water quality in the Little Wind River.

The analysis of seasonal variations in the direction of groundwater flows determined there is no evidence of groundwater flow from the UMTRA site toward the Wind River.

Groundwater in the lower confined bedrock aquifer does not appear to be vulnerable to contamination from the upper unconfined alluvial aquifer. There is evidence of contaminated groundwater having migrated down into the intermediate semiconfined aquifer in several areas as concentrations of manganese and sulfate above background were measured in two wells (DOE wells 723 and 732), above background for manganese in DOE well 111, above background for molybdenum in DOE well 732, and above background for sulfate in several wells (DOE wells 705, 717, 719, and 735). The concentration of molybdenum (except in DOE well 732) and uranium were never measured above background. In the riparian zone of the Little Wind River, the available waterelevation data indicate that (1) there is a consistent hydraulic gradient from the upper unconfined alluvial aquifer down into the intermediate semiconfined bedrock aquifer on both sides of the river, (2) there is a prevalent hydraulic gradient from the lower confined bedrock aquifer up into the intermediate semiconfined bedrock aquifer on both sides of the river, (3) the hydraulic gradient in the upper unconfined alluvial aquifer on the north side of the river is from northwest to southeast but reverses in the floodplain of the river during high flows associated with snowmelt runoff, and (4) the hydraulic gradient in the intermediate semiconfined bedrock aquifer in the vicinity of the Little Wind River is from the northwest to the southeast but also reverses during high flows associated with snowmelt runoff. The degree of the hydraulic connection between the Little Wind River and the upper unconfined alluvial aquifer and the intermediate semiconfined bedrock aquifer on both sides of the river needs to be determined.

The current monitoring network has adequately delineated the horizontal extent of the occurrences of above-background concentrations of arsenic, manganese, molybdenum, sulfate, and uranium in all three aquifers. Nickel was measured above the detection limit only in DOE wells 707 and 718. Data for boron, iron, lead, selenium, and vanadium were limited but indicate that these contaminants are present at background concentrations throughout each aquifer. Following the flooding of the Little Wind River in June 2010, there were large increases in manganese, molybdenum, sulfate, and uranium concentrations above what had been measured for many years in several wells adjacent to the river.

Data to evaluate the influence of water in the Koch drainage ditch on the Little Wind River were limited. The available data indicate that the water in the Koch drainage ditch is affecting the concentration of sulfate only to any measurable degree in West Side Creek and that sulfate in West Side Creek appears to be diluted as it flows into the Little Wind River.

The major data gaps identified in this study are that the available data do not adequately define the seasonal variability in water elevations, nor the values of field properties, major ions, and trace elements in groundwater and the Little Wind River.

\section{Introduction}

A uranium and vanadium processing mill, which produced yellowcake $\left(\mathrm{U}_{3} \mathrm{O}_{8}\right.$ - used in the preparation of uranium fuel for nuclear reactors) using both acid and alkaline mill circuits, operated on the Wind River Indian Reservation southwest of Riverton, Wyoming, from 1958 to 1963 (fig. 1) 

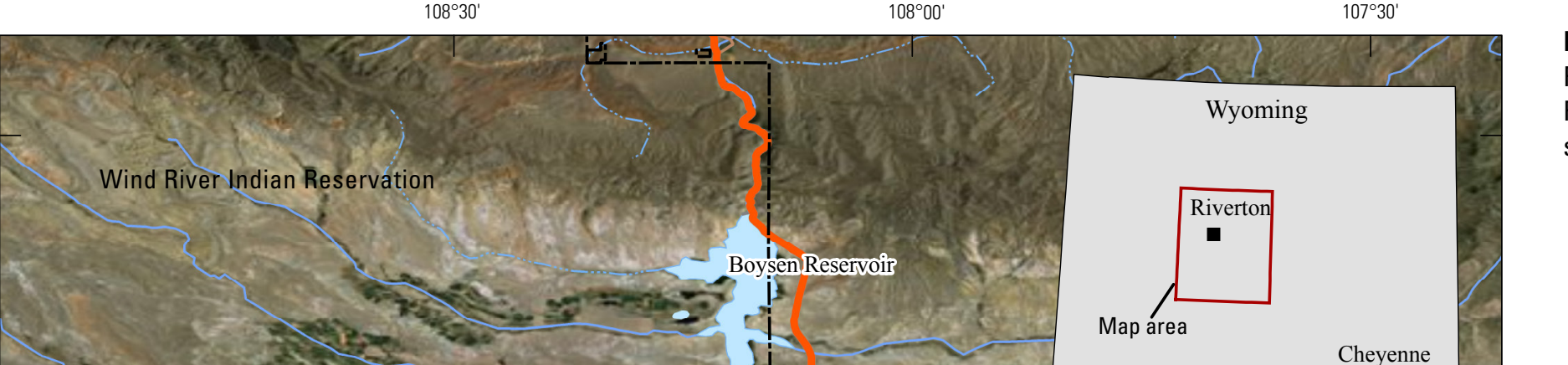

Rerton Uranium Mill Tailings

Remedial Action (UMTRA)

site, Riverton, Wyoming.

$43^{\circ} 00^{\prime}$

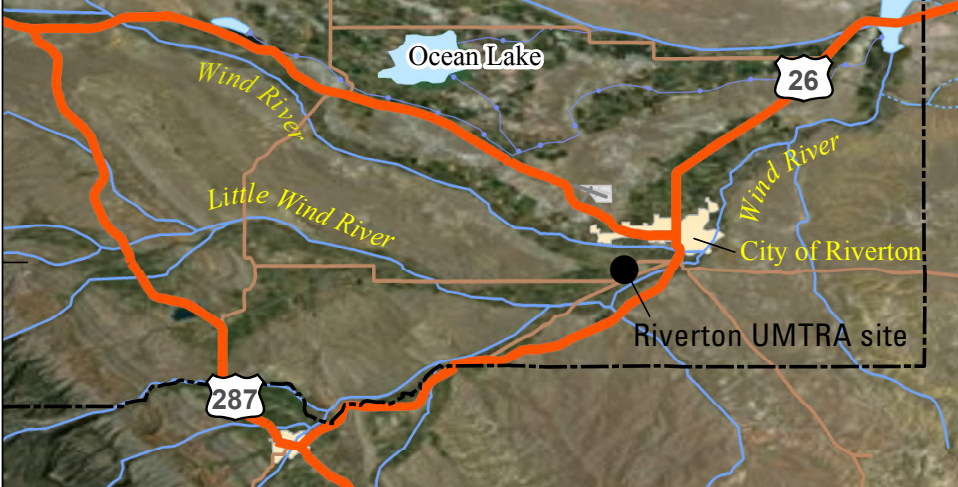

$42^{\circ} 30^{\circ}$

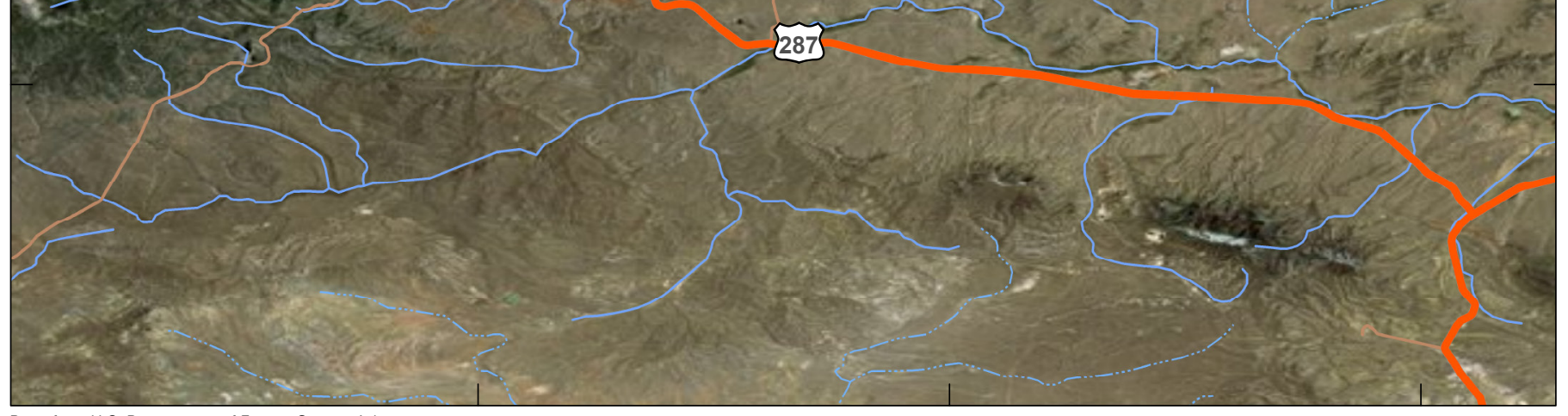

789

Base from U.S. Department of Energy Geospatial

Environmental Mapping Systems (GEMS)

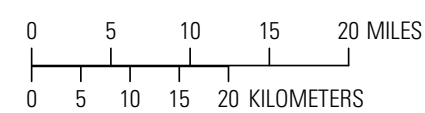

20

Gas Hills disposal site 
(U.S. Department of Energy, 1995). Sulfuric acid for milling operations was produced at an on-site facility that is still in operation today. Approximately 1.8 million cubic yards of contaminated mill tailings were stockpiled on 70 acres southeast of the mill (U.S. Department of Energy, 1995). The U.S. Department of Energy (DOE) was authorized to clean up the site under the Uranium Mill Tailings Radiation Control Act of 1978. The area of the former uranium mill and the area affected by elevated (above background) concentrations of uranium, other trace elements (arsenic, boron, iron, lead, manganese, mercury, molybdenum, nickel, selenium, and vanadium), and sulfate in groundwater, as shown in figure 2, is the Uranium Mill Tailings Remedial Action (UMTRA) Project. It is referred to as the UMTRA site in this report. The DOE (1995) has classified manganese, molybdenum, sulfate, and uranium as contaminants of concern (COCs) and arsenic, boron, iron, lead, mercury, nickel, selenium, and vanadium as contaminants of potential concern (COPCs). During surface remediation, about 1.8 million cubic yards of contaminated material were removed from the UMTRA site and disposed of at the Umetco Gas Hills disposal site (fig. 1), 55 miles eastsoutheast of Riverton. Surface remedial action was completed by the DOE in November 1989.

Since 1989, the DOE has been monitoring groundwater quality in 76 wells completed in three different aquifers (an upper unconfined alluvial aquifer, an intermediate semiconfined bedrock aquifer, and a lower confined bedrock aquifer) and at 9 surface-water sites. A representative cross section of the three aquifers, the direction of groundwater flow in the upper unconfined alluvial aquifer, and a conceptual model of groundwater hydrology at the UMTRA site determined by DOE are shown in figures 3-5.

The DOE reported in the 1995 Baseline Risk Assessment (U.S. Department of Energy, 1995) and the 1998 Groundwater Compliance Action Plan (U.S. Department of Energy, 1998) that groundwater in the upper unconfined alluvial aquifer and the hydraulically connected intermediate semiconfined bedrock aquifer downgradient from the former uranium mill is affected by dissolved uranium and other trace elements and flows southeast from the UMTRA site and discharges to the Little Wind River. The DOE also reported that the water quality in the lower confined bedrock aquifer had not been affected by releases from the uranium mill operations. The affected groundwater is derived from uranium milling operations, waste storage, and infiltration of precipitation through the tailings left in place at the UMTRA site. DOE considers a constituent to be a contaminant of concern if the concentration in the groundwater exceeds the unaffected background concentration (U.S. Department of Energy, 1998). DOE defines the term background as "concentrations of constituents in the uppermost aquifer that were not affected by processing activities" (U.S. Department of Energy, 1998).

The DOE's selected remediation strategy for groundwater at the UMTRA site is to achieve compliance with U.S. Environmental Protection Agency (EPA) groundwater standards in 40 Code of Federal Regulations (CFR) part 192 by natural attenuation with institutional controls and monitoring (U.S. Department of Energy, 1998). Institutional controls, which consist of protocols designed to limit or eliminate the current and future use of the property in an effort to control or eliminate exposure pathways, must effectively protect public health and the environment. Examples of these protocols include water-well-drilling restrictions, deed restrictions on future use of the property, and fencing and signage to keep people off the property. This strategy is acceptable to the EPA provided the cleanup will occur within 100 years. Cleanup, as defined by the DOE, is achieved when the concentration of uranium in groundwater decreases to less than 0.044 milligrams per liter $(\mathrm{mg} / \mathrm{L})$ and molybdenum in groundwater decreases to less than $0.1 \mathrm{mg} / \mathrm{L}$. EPA regulations permit natural attenuation with institutional controls and monitoring to be used in place of active remediation only when DOE is able to ensure that adequate institutional controls can be maintained during the 100 -year remediation period.

In 2010, the U.S Geological Survey, in cooperation with the Wind River Environmental Quality Commission (WREQC), began an assessment of the effectiveness of the existing monitoring network at the Riverton, Wyoming, Uranium Mill Tailings Remedial Action (UMTRA) site. The USGS used existing data supplied by the DOE to address the following objectives:

1. Determine seasonal variations in directions of groundwater flow in the area of the former uranium processing mill. Data collected by the DOE shows that groundwater beneath the site of the former uranium processing mill, where the sulfuric-acid plant exists today, flows from the former mill site southeast to the Little Wind River (fig. 4). The WREQC is concerned that seasonal canal diversions for irrigation (May or June through late July to early September) from the Wind River upgradient from the UMTRA site may affect groundwater-flow directions and that groundwater in the upper unconfined alluvial aquifer with elevated concentrations of uranium may flow north into the Wind River.

2. Determine the extent of contaminated groundwater among the aquifers and the Little Wind River. The WREQC is concerned that the degree of hydraulic connection among the three aquifers and the Little Wind River is not fully characterized, and, thus, the extent of groundwater and surface water containing uranium and other COCs and COPCs at concentrations greater than background is not fully characterized.

3. Determine if current monitoring is adequate to determine the effectiveness of natural attenuation for the contaminants of concern. The WREQC has requested an evaluation of the DOE monitoring network to determine if there are sufficient numbers of wells appropriately located both vertically and horizontally to effectively monitor natural attenuation of all COCs and COPCs. The WREQC is concerned that the previous 


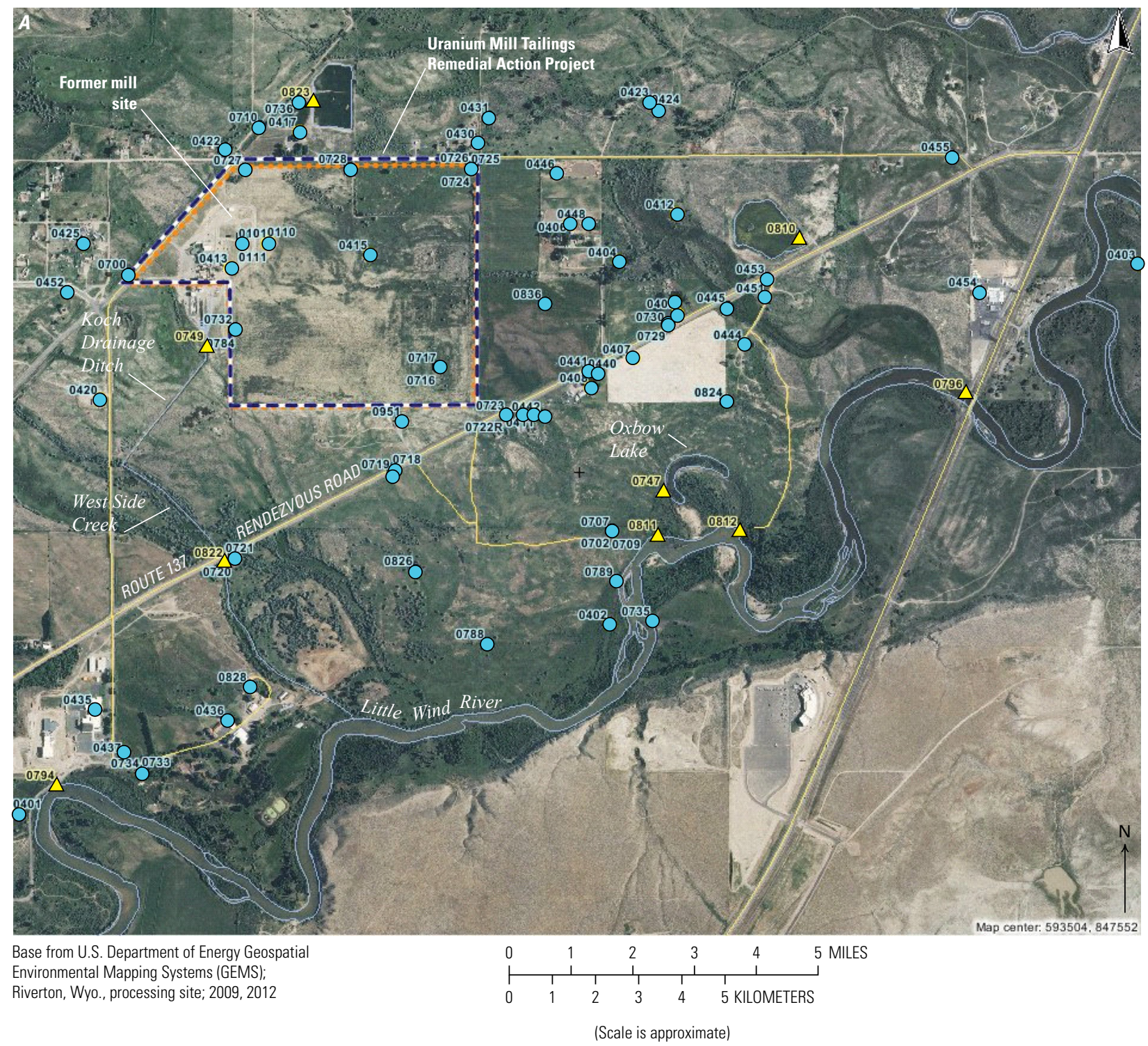

Figure 2. Location of the U.S. Department of Energy groundwater monitoring wells (blue circles); abandoned groundwater monitoring wells (red circles), and surface-water monitoring sites (triangles) on the Uranium Mill Tailings Remedial Action site on the Wind River Indian Reservation, Wyoming. $A$, Existing groundwater monitoring wells and $B$, abandoned groundwater monitoring well. 


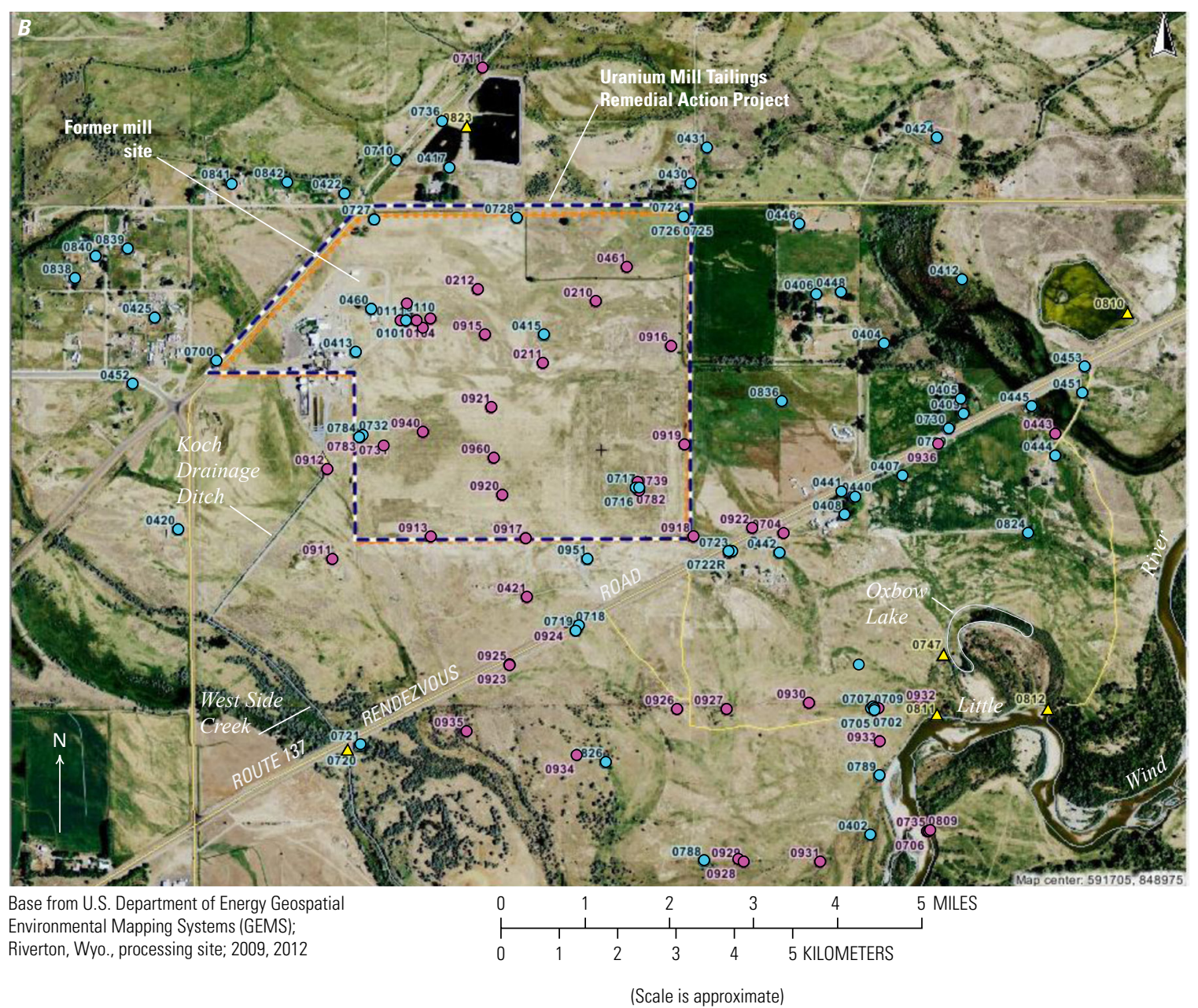

Figure 2. Location of the U.S. Department of Energy groundwater monitoring wells (blue circles); abandoned groundwater monitoring wells (red circles), and surface-water monitoring sites (triangles) on the Uranium Mill Tailings Remedial Action site on the Wind River Indian Reservation, Wyoming. A, Existing groundwater monitoring wells and $B$, abandoned groundwater monitoring well.-Continued 


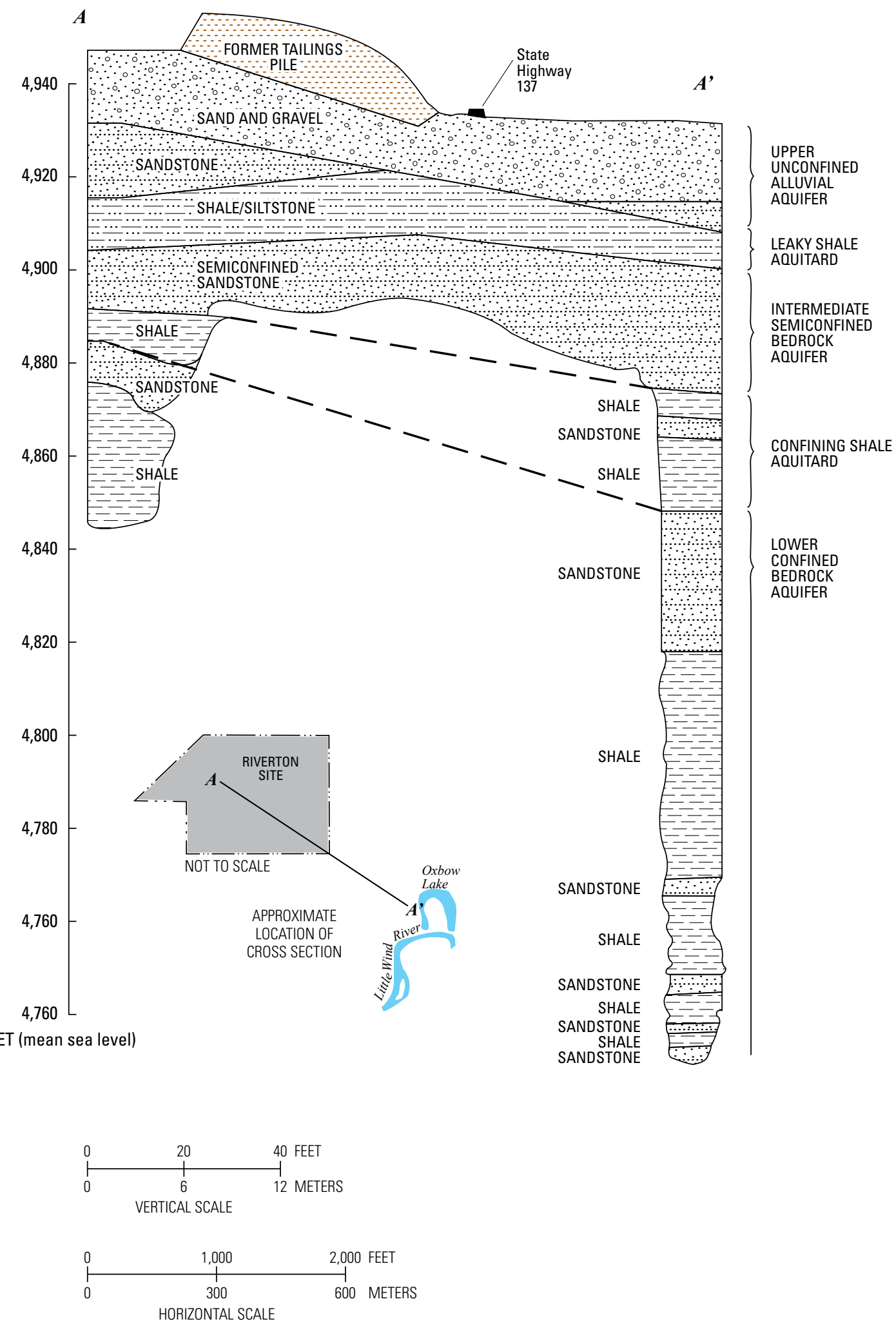

Figure 3. Geologic cross section of the Riverton Uranium Mill Tailings Remedial Action site on the Wind River Indian Reservation. 


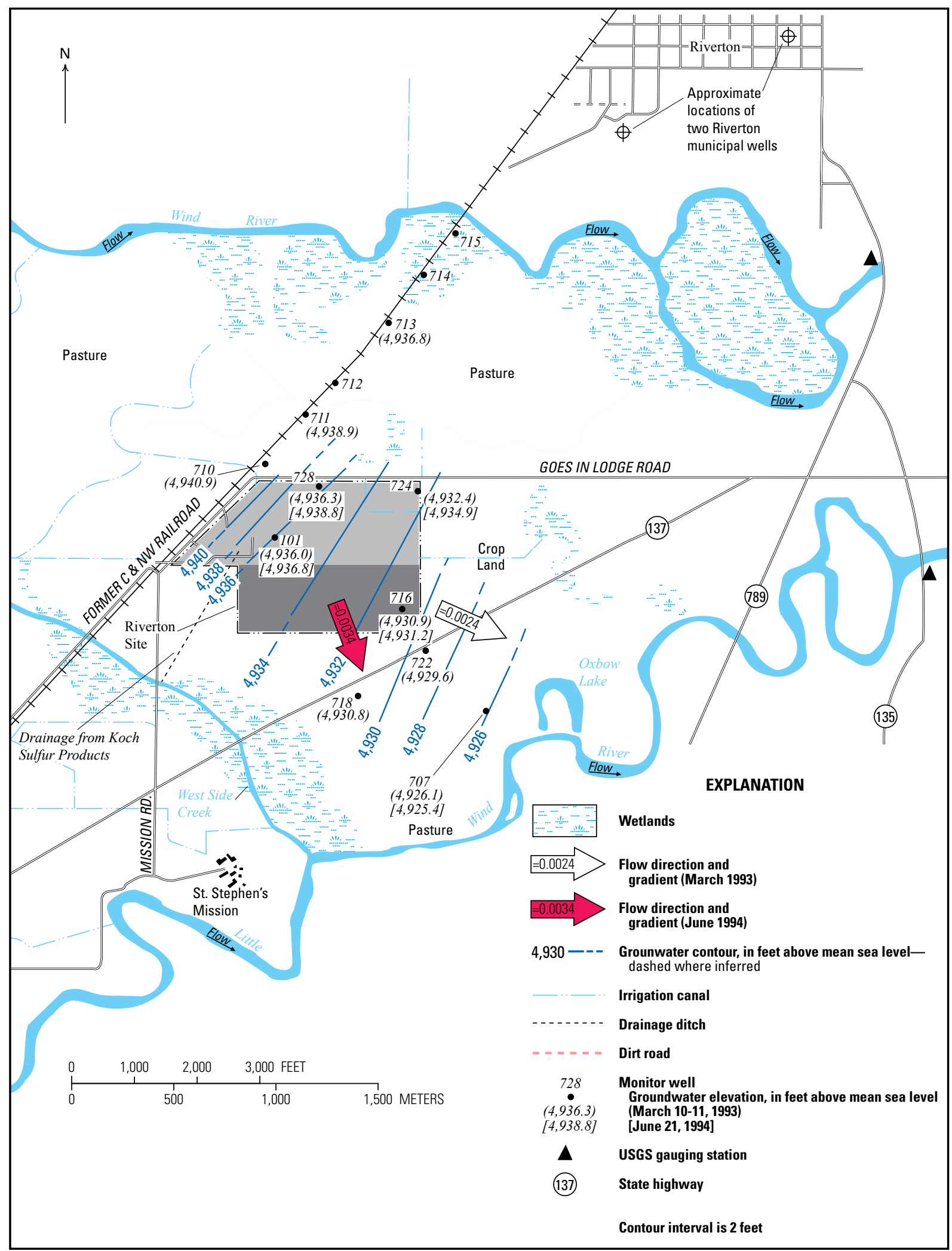

Figure 4. Hydraulic-head elevation and generalized flow directions in the upper unconfined alluvial aquifer. 


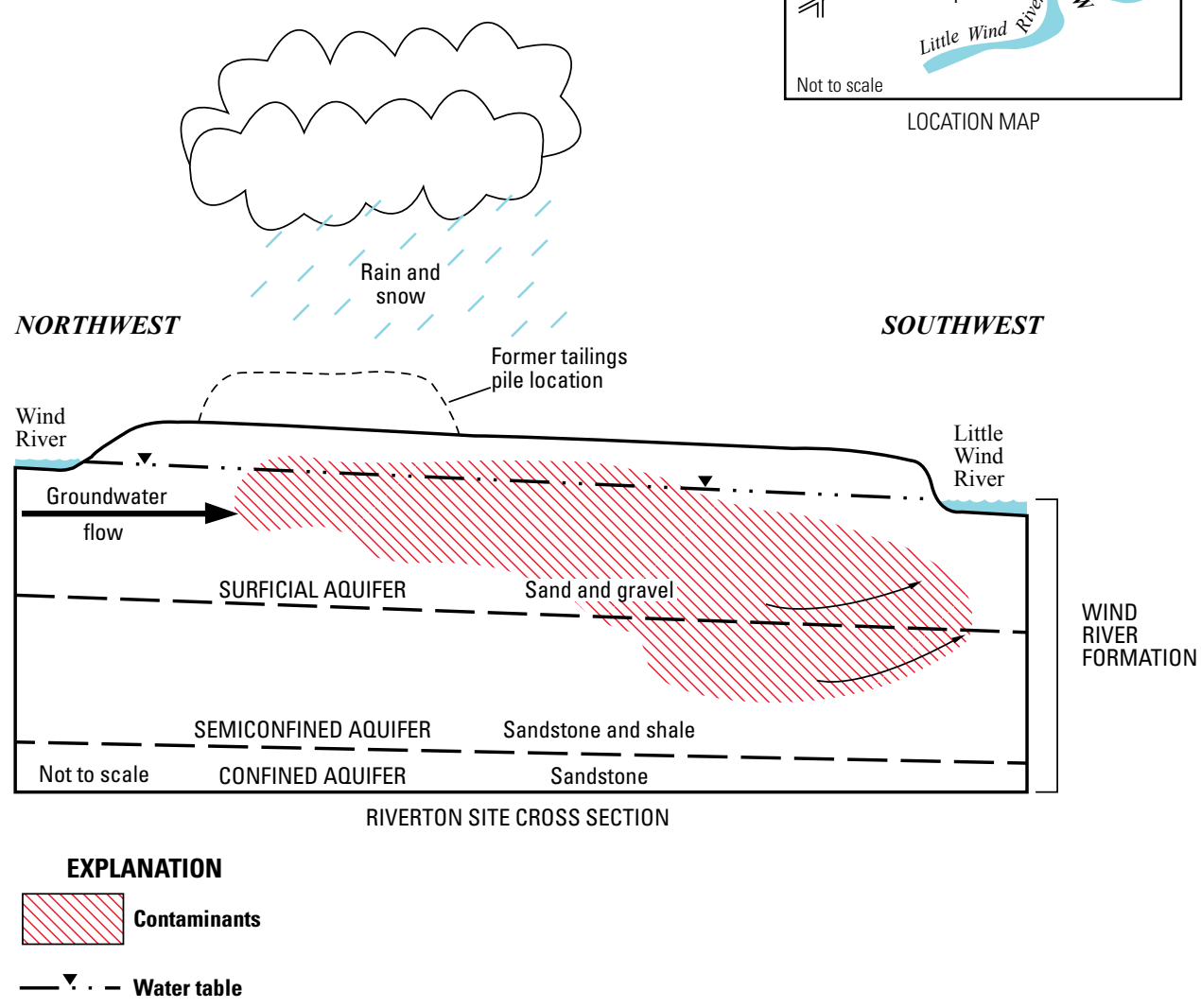

Figure 5. Conceptual hydrologic model of the Uranium Mill Tailings Remedial Action site.

monitoring by the DOE does not adequately address the effectiveness of natural attenuation of uranium and other trace elements including arsenic, boron, iron, lead, manganese, mercury, molybdenum, nickel, selenium, vanadium, and sulfate.

4. Determine the influence of groundwater discharged from the sulfuric-acid plant site on water quality in the Little Wind River. Groundwater is pumped from the lower confined bedrock aquifer near the sulfuricacid plant and is discharged under a National Pollutant Discharge Elimination System (NPDES) permit to a small stream (West Side Creek) that flows into the Little Wind River (fig. 2). The WREQC has requested an assessment of the potential of West Side Creek to affect the water quality of the Little Wind River.

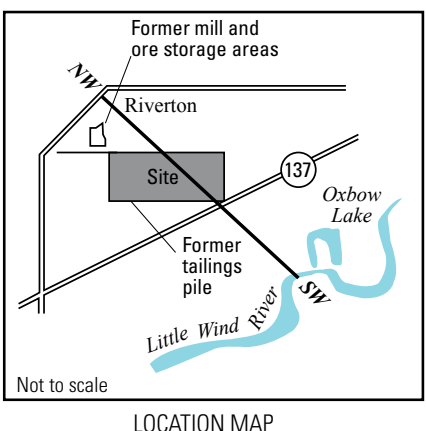

SOUTHWEST 


\section{Description of Study Area}

The Wind River Reservation is located in west-central Wyoming (fig. 1). The UMTRA site is located on a nearly level alluvial terrace about 2.5 miles west of the confluence of the Little Wind River and Wind River (U.S. Department of Energy, 1995). The Little Wind River is located about 3,000 feet to the southeast of the site, and the Wind River is located about 4,000 feet to the north. The land-surface elevation at the site averages about 4,950 feet above mean sea level and slopes at less than 0.5 percent to the southeast. A system of irrigation canals is located along the northern and eastern sides of the property. These canals carry water from the Wind River to the northwest and discharge into the wetlands area east of the site. The irrigation system operates from June to October.

The upper unconfined alluvial aquifer that underlies the UMTRA site consists of unconsolidated deposits of Quaternary age flood-plain alluvium and low terraces (McGreevy and others, 1969). The flood-plain alluvium consists mostly of unconsolidated deposits of silt, sand, gravel, cobbles, and boulders that range from 5 to more than 100 feet in thickness but are generally less than 40 feet thick (Daddow, 1996). The terrace deposits consist of unconsolidated deposits of silt, sand, gravel, cobbles, and boulders and usually appear as bench or steplike features that are usually less than 50 feet but may be as much as 200 feet thick. Groundwater in the upper unconfined alluvial aquifer that underlies the UMTRA site moves to the eastsoutheast and is within 10 feet of land surface (Daddow, 1996). Groundwater-elevation data collected by the DOE also indicate that groundwater moves southeast from the UMTRA site toward the Little Wind River (fig. 4).

The intermediate semiconfined bedrock aquifer and the lower confined bedrock aquifer that underlies the UMTRA site consist of the Wind River Formation (White and others, 1984; U.S. Department of Energy, 1995). The Wind River Formation is a Tertiary age (Eocene) stream deposit composed of erosional debris of mixed sandstone, conglomerate, shale, and mudstone with small quantities of bentonite, tuff, and limestone. Groundwater-elevation data collected by the DOE show that groundwater moves southeast from the UMTRA site toward the Little Wind River in both of these aquifers (U.S. Department of Energy, 1998).

U.S. Department of Energy (1998) asserts that these aquifers are recharged primarily by inflow from the Wind River to the northwest and from excess irrigation water. Discharge of groundwater from the surficial aquifer is presumed to flow into Oxbow Lake and Little Wind River with some discharge occurring to the wetlands southeast of the site, whereas discharge of groundwater from the semiconfined aquifer is presumed to flow into the Little Wind River. White and others (1984) analyzed water samples collected from the Wind River, Little Wind River, and groundwater from the UMTRA site for deuterium $\left({ }^{2} \mathrm{H}\right)$ and oxygen-18 $\left({ }^{18} \mathrm{O}\right)$ isotope ratios in water molecules. They found that the Wind River, Little Wind River, shallow groundwater, and deep groundwater have similar isotopic ratios, which they interpreted as indicating a common hydrologic source. Samples were also collected from several shallow and deep aquifer wells for tritium $\left({ }^{3} \mathrm{H}\right)$. Groundwater in the shallow aquifer had high values of tritium units (65-96 tritium units (TU); $1 \mathrm{TU}=$ one tritium atom in $10^{18}$ atoms of hydrogen) indicating modern recharge (post-1952). Tritium analyses can also be reported in units of picocuries per liter $(\mathrm{pCi} / \mathrm{L})$ where $1 \mathrm{TU}=3.2 \mathrm{pCi} / \mathrm{L}$ ). Tritium concentrations in domestic wells completed in the intermediate semiconfined aquifer and the lower confined bedrock aquifer (referred to as the Wind River aquifer in White and others, 1984) are low (about $1 \mathrm{TU}$ ) indicating negligible recharge since 1952 . White and others (1984) state that this age difference implies a lack of connection among the aquifers and low potential for contamination of the Wind River aquifers.

\section{Quality of Groundwater and the Little Wind River}

\section{Background Concentrations of the Contaminants of Concern}

Background water quality is defined as the naturally occurring water quality in the absence of influence from the former uranium processing facility. In this study, the flow of groundwater is southeast from the former mill site toward the Little Wind River; therefore, background groundwater quality is obtained from groundwater wells located northwest and north of the former mill site (fig. 2). The wells chosen to represent background water-quality conditions are as follows. In the upper unconfined alluvial aquifer, the wells are DOE wells 710, 711 (abandoned), 724, 728, and domestic well 431. In the intermediate semiconfined bedrock aquifer, the wells are DOE wells 725,727 , and 736 . In the lower confined bedrock aquifer, the wells are DOE well 726 and domestic wells 417, 423 , and 430 .

It is necessary to obtain an understanding of background groundwater quality to accomplish the objectives of this study because all of the COCs and COPCs associated with the mill tailings sites also occur naturally. An understanding of concentrations that may occur naturally are necessary to determine the spatial extent of the plume downgradient from the former mill site and the duration of contamination. In other words, by understanding the concentrations of the COCs and COPCs that occur naturally in the area, it may be possible to define the horizontal and vertical extent of the COCs and COPCs and the duration of the contamination (how long it takes the COCs and COPCs to decline to background levels). Also the mobility of uranium and the other COCs and COPCs is a function of the water chemistry of the aquifer they are introduced in and the physical properties of the material composing the aquifer. For example, uranium tends to be most mobile in groundwater when it is exists in solution as $\mathrm{U}^{6+}$ and 
forms soluble phosphate and uranyl-carbonate complexes in oxidizing alkaline water (Zielinski and others, 1997; Sherman and others, 2007). These conditions can occur in near-surface, unconfined aquifers that are open to exchange with the atmosphere and contain sparse organic matter (Zielinski and others, 1997).

In each aquifer the available groundwater-quality data ( $\mathrm{pH}$, specific conductance, major ions, and COCs and COPCs) are summarized to develop a classification of background water quality that will be used to compare with groundwater downgradient from the former mill site. Background water quality may also be evaluated by comparing the concentrations of the COCs and COPCs to the State of Wyoming waterquality standards of groundwater for agricultural (irrigation) and livestock use (Daddow, 1996) and EPA groundwater standards listed in 40 CFR 192.02 Table 1 to Subpart A (http:// www.gpo.gov/fdsys/pkg/CFR-2012-title40-vol26/pdf/ CFR-2012-title40-vol26-part192-subpartA-app1.pdf) (table1). Piper diagrams (Piper, 1944) are used to show average major ion chemistry as percentages of each ion.

The USGS geochemical model PHREEQC (Parkhurst and Appelo, 2010; and http://wwwbrr.cr.usgs.gov/projects/ GWC_coupled/phreeqc/), using the wateq4f.dat and minteq. v4.dat (molybdenum species only) databases, was used to calculate the saturation indices of the commonly occurring minerals calcite $\left(\mathrm{CaCO}_{3}\right)$, dolomite $\left(\mathrm{CaMg}\left(\mathrm{CO}_{3}\right)_{2}\right)$, and gypsum $\left(\mathrm{CaSO}_{4}: 2 \mathrm{H}_{2} \mathrm{O}\right)$, the arsenic-bearing mineral arsenolite $\left(\mathrm{As}_{2} \mathrm{O}_{3}\right)$, the uranium-bearing minerals coffinite $\left(\mathrm{USiO}_{4}\right)$, rutherfordine $\left(\mathrm{UO}_{2} \mathrm{CO}_{3}\right)$, schoepite $\left(\mathrm{UO}_{2}(\mathrm{OH})_{2}: \mathrm{H}_{2} \mathrm{O}\right)$, uraninite $\left(\mathrm{UO}_{2}\right)$, and uranophane $\left(\mathrm{Ca}\left(\mathrm{UO}_{2}\right)_{2}\left(\mathrm{SiO}_{3} \mathrm{OH}\right)_{2}\right)$, and various other solid phases containing the COCs and COPCs in the groundwater within each aquifer. It needs to be noted that PHREEQC will produce a list of potential mineral phases that could potentially dissolve or precipitate out of solution. Mineralogical evidence from the field site is needed to confirm the output from the PHREEQC modeling. PHREEQC also was used to calculate the predominant species of the dissolved COCs and COPCs in each aquifer. This modeling was done because the ionic form of the species that exist in solution will determine the tendency of an ion to remain in solution or sorb to aquifer sediments. The degree to which precipitation and (or) sorption occurs are major factors regulating the mobility of an ion in groundwater. Data for at least one date from one DOE groundwater well in each aquifer (DOE wells 710,725 , and 726) that had a $\mathrm{pH}$ value, an ORP (oxidation reduction potential) reading, concentrations of all major ions, a concentration of silica (to determine saturation with respect to coffinite and uranophane), and a concentration of uranium was selected for input to PHREEQC. Samples containing measurements of dissolved uranium were the priority for input into PHREEQC because uranium is the contaminant of most concern to the WREQC (U.S. Department of Energy, 1998). If concentration data for other COCs and COPCs were available for a chosen sample, then they were also entered into PHREEQC. The values of saturation indices for various minerals in groundwater calculated for all wells discussed throughout the report are presented in table 2. Table 2 also includes data from several surface-water sites on the Little Wind River. The data for the Little Wind River above Arapahoe, Wyo. (USGS site ID 062310000) was accessed from the USGS website at (http://nwis.waterdata.usgs.gov/ wy/nwis/qwdata). The DOE surface-water sites, LWR 794 and LWR 796, are the most upstream and downstream sampling sites on the Little Wind River and are shown in figure 2.

Table 1. State of Wyoming agricultural ${ }^{1}$ and U.S. Environmental Protection Agency (EPA) ${ }^{2}$ groundwater-quality standards.

$[\mathrm{mg} / \mathrm{L}$, milligram per liter; $\mu \mathrm{g} / \mathrm{L}$, microgram per liter; $\mathrm{N}$, nitrogen; --, no standard established]

\begin{tabular}{|c|c|c|c|c|}
\hline \multicolumn{5}{|c|}{ State of Wyoming groundwater-quality standards } \\
\hline & \multicolumn{2}{|c|}{ Irrigation } & \multicolumn{2}{|c|}{ Livestock use } \\
\hline & (mg/L) & ( $\mu \mathrm{g} / \mathrm{L})$ & (mg/L) & ( $\mu \mathrm{g} / \mathrm{L})$ \\
\hline Arsenic & 0.1 & 100 & 0.2 & 200 \\
\hline Boron & 0.75 & 750 & 5.0 & 5,000 \\
\hline Iron & 5.0 & 5,000 & -- & -- \\
\hline Lead & 5.0 & 5,000 & 0.1 & 100 \\
\hline Manganese & 0.2 & 200 & -- & -- \\
\hline Selenium & 0.02 & 20 & 0.05 & 50 \\
\hline Uranium & 5.0 & 5,000 & 5.0 & 5,000 \\
\hline \multicolumn{5}{|c|}{ EPA groundwater-quality standards } \\
\hline & \multicolumn{2}{|c|}{ Maximum } & & \\
\hline & (mg/L) & $(\mu \mathrm{g} / \mathrm{L})$ & & \\
\hline Arsenic & 0.05 & 50 & & \\
\hline Barium & 1.0 & 1,000 & & \\
\hline Cadmium & 0.01 & 10 & & \\
\hline Chromium & 0.05 & 50 & & \\
\hline Lead & 0.05 & 50 & & \\
\hline Mercury & 0.002 & 2 & & \\
\hline Selenium & 0.01 & 10 & & \\
\hline Silver & 0.05 & 50 & & \\
\hline Nitrate (as N) & 10 & 10,000 & & \\
\hline Molybdenum & 0.1 & 100 & & \\
\hline Uranium & 0.044 & 44 & & \\
\hline
\end{tabular}

${ }^{1}$ State of Wyoming standards (Daddow, 1996)

${ }^{2}$ U.S. Environmental Protection Agency groundwater-quality standards, (http://www.gpo.gov/fdsys/pkg/CFR-2012-title40-vol26/pdf) CFR-2012-title40-vol26-part192-subpartA-app1.pdf) 
Table 2. Saturation indices for dissolved arsenic, boron, lead, manganese, mercury, molybdenum, nickel, selenium, uranium, and vanadium data in the upper unconfined alluvial aquifer.

[ORP, oxidation reduction potential in millivolts; LWR, Little Wind River; <, less than; --, no data]

\begin{tabular}{|c|c|c|c|c|c|c|c|c|c|c|c|c|c|c|c|c|c|c|c|c|c|}
\hline \multicolumn{22}{|c|}{ Upper unconfined alluvial aquifer-Upgradient wells } \\
\hline & & & $\begin{array}{c}\text { Arseno- } \\
\text { lite }\end{array}$ & Barite & Calcite & Dolomite & Gypsum & $\begin{array}{l}\text { Hausman- } \\
\text { nite }\end{array}$ & $\begin{array}{l}\text { Manga- } \\
\text { nite }\end{array}$ & Nsutite & $\begin{array}{l}\text { Pyrolu- } \\
\text { site }\end{array}$ & $\begin{array}{l}\text { Rhodo- } \\
\text { chrosite }\end{array}$ & $\begin{array}{c}\text { Cof- } \\
\text { finite }\end{array}$ & $\begin{array}{l}\text { Ruther- } \\
\text { fordine }\end{array}$ & Schoepite & Uraninite & $\begin{array}{l}\text { Urano- } \\
\text { phane }\end{array}$ & & olybdenum & solid phase & \\
\hline Well & Date & ORP & $\mathrm{As}_{2} \mathrm{O}_{3}$ & $\mathrm{BaSO}_{4}$ & $\mathrm{CaCO}_{3}$ & $\mathrm{CaMg}\left(\mathrm{CO}_{3}\right)_{2}$ & $\mathrm{CaSO}_{4}: 2 \mathrm{H}_{2} \mathrm{O}$ & $\mathrm{Mn}_{3} \mathrm{O}_{4}$ & $\mathrm{MnOOH}$ & $\mathrm{MnO}_{2}$ & $\mathrm{MnO}_{2}$ & $\mathrm{MnCO}_{3}$ & $\mathrm{USiO}_{4}$ & $\mathrm{UO}_{2} \mathrm{CO}_{3}$ & $\mathrm{UO}_{2}(\mathrm{OH})_{2}: \mathrm{H}_{2} \mathrm{O}$ & $\mathrm{UO}_{2}$ & $\begin{array}{r}\mathrm{Ca}\left(\mathrm{UO}_{2}\right) \\
\left(\mathrm{SiO}_{3} \mathrm{OH}\right)_{2} \\
\end{array}$ & $\mathrm{CaMoO}_{4}$ & $\mathrm{MgMoO}_{4}$ & $\mathrm{Na}_{2} \mathrm{MoO}_{4}$ & $\mathrm{~K}_{2} \mathrm{MoO}_{4}$ \\
\hline 710 & $3 / 11 / 1993$ & 671 & -- & -- & 0.16 & -0.26 & -1.53 & -- & -- & -- & -- & -- & -25.28 & -7.87 & -7.83 & -24.98 & -15.97 & -- & -- & -- & -- \\
\hline 710 & $5 / 15 / 1998$ & 322 & -35.72 & -- & -0.07 & -0.72 & -1.54 & -16.06 & -4.36 & -8.59 & -10.64 & -1.6 & -12.81 & -7.43 & -7.15 & -12.50 & -14.64 & -- & -- & -- & -- \\
\hline \multicolumn{22}{|c|}{ Intermediate semiconfined bedrock aquifer-Upgradient wells } \\
\hline & & & $\begin{array}{c}\text { Arseno- } \\
\text { lite }\end{array}$ & Barite & Calcite & Dolomite & Gypsum & $\begin{array}{l}\text { Hausman- } \\
\text { nite }\end{array}$ & $\begin{array}{c}\begin{array}{c}\text { Manga- } \\
\text { nite }\end{array} \\
\end{array}$ & Nsutite & $\begin{array}{c}\begin{array}{c}\text { Pyrolu- } \\
\text { site }\end{array} \\
\end{array}$ & $\begin{array}{l}\begin{array}{l}\text { Rhodo- } \\
\text { chrosite }\end{array} \\
\end{array}$ & $\begin{array}{c}\text { Cof- } \\
\text { finite }\end{array}$ & $\begin{array}{l}\text { Ruther- } \\
\text { fordine }\end{array}$ & Schoepite & Uraninite & $\begin{array}{l}\text { Urano- } \\
\text { phane }\end{array}$ & \multicolumn{4}{|c|}{ Molybdenum solid phases } \\
\hline Well & Date & ORP & $\mathrm{As}_{2} \mathrm{O}_{3}$ & $\mathrm{BaSO}_{4}$ & $\mathrm{CaCO}_{3}$ & $\mathrm{CaMg}\left(\mathrm{CO}_{3}\right)_{2}$ & $\mathrm{CaSO}_{4}: 2 \mathrm{H}_{2} \mathrm{O}$ & $\mathrm{Mn}_{3} \mathrm{O}_{4}$ & $\mathrm{MnOOH}$ & $\mathrm{MnO}_{2}$ & $\mathrm{MnO}_{2}$ & $\mathrm{MnCO}_{3}$ & $\mathrm{USiO}_{4}$ & $\mathrm{UO}_{2} \mathrm{CO}_{3}$ & $\mathrm{UO}_{2}(\mathrm{OH})_{2}: \mathrm{H}_{2} \mathrm{O}$ & $\mathrm{UO}_{2}$ & $\begin{array}{c}\mathrm{Ca}\left(\mathrm{UO}_{2}\right) \\
\left(\mathrm{SiO}_{3} \mathrm{OH}\right)_{2}\end{array}$ & $\mathrm{CaMoO}_{4}$ & $\mathrm{MgMoO}_{4}$ & $\mathrm{Na}_{2} \mathrm{MoO}_{4}$ & $\mathrm{~K}_{2} \mathrm{MoO}_{4}$ \\
\hline 725 & 2/7/1997 & 279 & -31.19 & -- & 0.14 & -0.38 & -1.29 & -17.48 & -5.44 & -10.75 & -12.31 & -0.73 & -11.80 & -7.46 & -7.97 & -11.37 & -17.28 & -- & -- & -- & -- \\
\hline 727 & 2/5/1997 & 125 & -23.04 & -- & -0.33 & -1.46 & -1.64 & -20.3 & -7.48 & -15.15 & -16.09 & -1.08 & -6.81 & -7.52 & -7.27 & -6.23 & -16.07 & -- & -- & -- & -- \\
\hline \multicolumn{22}{|c|}{ Lower confined bedrock aquifer-Upgradient wells } \\
\hline & & & $\begin{array}{c}\text { Arseno- } \\
\text { lite }\end{array}$ & Barite & Calcite & Dolomite & Gypsum & $\begin{array}{c}\text { Hausman- } \\
\text { nite }\end{array}$ & $\begin{array}{c}\begin{array}{c}\text { Manga- } \\
\text { nite }\end{array} \\
\end{array}$ & Nsutite & $\begin{array}{c}\begin{array}{c}\text { Pyrolu- } \\
\text { site }\end{array} \\
\end{array}$ & $\begin{array}{l}\begin{array}{l}\text { Rhodo- } \\
\text { chrosite }\end{array} \\
\end{array}$ & $\begin{array}{c}\text { Cof- } \\
\text { finite }\end{array}$ & $\begin{array}{l}\text { Ruther- } \\
\text { fordine }\end{array}$ & Schoepite & Uraninite & $\begin{array}{l}\text { Urano- } \\
\text { phane }\end{array}$ & \multicolumn{4}{|c|}{ Molybdenum solid phases } \\
\hline Well & Date & ORP & $\mathrm{As}_{2} \mathrm{O}_{3}$ & $\mathrm{BaSO}_{4}$ & $\mathrm{CaCO}_{3}$ & $\mathrm{CaMg}\left(\mathrm{CO}_{3}\right)_{2}$ & $\mathrm{CaSO}_{4}: 2 \mathrm{H}_{2} \mathrm{O}$ & $\mathrm{Mn}_{3} \mathrm{O}_{4}$ & $\mathrm{MnOOH}$ & $\mathrm{MnO}_{2}$ & $\mathrm{MnO}_{2}$ & $\mathrm{MnCO}_{3}$ & $\mathrm{USiO}_{4}$ & $\mathrm{UO}_{2} \mathrm{CO}_{3}$ & $\mathrm{UO}_{2}(\mathrm{OH})_{2}: \mathrm{H}_{2} \mathrm{O}$ & $\mathrm{UO}_{2}$ & $\begin{array}{c}\mathrm{Ca}\left(\mathrm{UO}_{2}\right) \\
\left(\mathrm{SiO}_{3} \mathrm{OH}\right)_{2}\end{array}$ & $\mathrm{CaMoO}_{4}$ & $\mathrm{MgMoO}_{4}$ & $\mathrm{Na}_{2} \mathrm{MoO}_{4}$ & $\mathrm{~K}_{2} \mathrm{MoO}_{4}$ \\
\hline 726 & $4 / 19 / 1993$ & 451 & -- & -- & 0.6 & 0.53 & -2.07 & 2.18 & 2.62 & 2.34 & 1.1 & -0.66 & -21.47 & -9.76 & -7.25 & -20.85 & -12.83 & -- & --- & -- & -- \\
\hline 726 & $5 / 14 / 1998$ & 63 & -- & -- & -0.2 & -1.49 & -2.75 & -11.54 & -4.09 & -10.97 & -12.31 & -0.75 & -7.33 & -8.82 & -6.36 & -6.74 & -11.83 & -- & -- & -- & -- \\
\hline \multicolumn{22}{|c|}{ Upper unconfined alluvial aquifer-Plume wells } \\
\hline & & & $\begin{array}{c}\text { Arseno- } \\
\text { lite }\end{array}$ & Barite & Calcite & Dolomite & Gypsum & $\begin{array}{c}\text { Hausman- } \\
\text { nite }\end{array}$ & $\begin{array}{c}\text { Manga- } \\
\text { nite }\end{array}$ & Nsutite & $\begin{array}{c}\text { Pyrolu- } \\
\text { site }\end{array}$ & $\begin{array}{l}\text { Rhodo- } \\
\text { chrosite }\end{array}$ & $\begin{array}{l}\text { Cof- } \\
\text { finite }\end{array}$ & $\begin{array}{l}\text { Ruther- } \\
\text { fordine }\end{array}$ & Schoepite & Uraninite & $\begin{array}{l}\text { Urano- } \\
\text { phane }\end{array}$ & \multicolumn{4}{|c|}{ Molybdenum solid phases } \\
\hline Well & Date & ORP & $\mathrm{As}_{2} \mathrm{O}_{3}$ & $\mathrm{BaSO}_{4}$ & $\mathrm{CaCO}_{3}$ & $\mathrm{CaMg}\left(\mathrm{CO}_{3}\right)_{2}$ & $\mathrm{CaSO}_{4}: 2 \mathrm{H}_{2} \mathrm{O}$ & $\mathrm{Mn}_{3} \mathrm{O}_{4}$ & $\mathrm{MnOOH}$ & $\mathrm{MnO}_{2}$ & $\mathrm{MnO}_{2}$ & $\mathrm{MnCO}_{3}$ & $\mathrm{USiO}_{4}$ & $\mathrm{UO}_{2} \mathrm{CO}_{3}$ & $\mathrm{UO}_{2}(\mathrm{OH})_{2}: \mathrm{H}_{2} \mathrm{O}$ & $\mathrm{UO}_{2}$ & $\begin{array}{c}\mathrm{Ca}\left(\mathrm{UO}_{2}\right) \\
\left(\mathrm{SiO}_{3} \mathrm{OH}\right)_{2}\end{array}$ & $\mathrm{CaMoO}_{4}$ & $\mathrm{MgMoO}_{4}$ & $\mathrm{Na}_{2} \mathrm{MoO}_{4}$ & $\mathrm{~K}_{2} \mathrm{MoO}_{4}$ \\
\hline 716 & 4/1/1993 & 729 & -- & -- & -0.11 & -0.84 & -0.6 & -1.8 & 2.59 & 4.66 & 2.43 & -0.1 & -23.92 & -5.09 & -5.70 & -23.58 & -12.68 & -0.61 & -7.12 & -11.73 & -17.05 \\
\hline 101 & 2/8/1997 & 296 & -32.58 & 0.33 & 0.27 & 0.11 & -0.72 & -14.3 & -4.29 & -9.16 & -10.61 & -0.35 & -11.36 & -6.67 & -6.82 & -11.15 & -14.08 & -1.48 & -7.89 & -12.75 & -17.96 \\
\hline 716 & 2/9/1997 & 270 & -30.10 & -- & -0.21 & -0.98 & -0.61 & -16.61 & -4.93 & -10.5 & -12.66 & -0.21 & -8.29 & -4.94 & -5.32 & -7.94 & -11.82 & -0.69 & -7.14 & -11.63 & -17.10 \\
\hline 707 & 2/18/1996 & 581 & -47.48 & -- & -0.02 & -0.36 & 0.19 & -6.23 & 0.06 & -0.55 & -2.47 & 0.28 & -18.21 & -4.70 & -5.49 & -18.14 & -11.92 & -- & -- & -- & -- \\
\hline 707 & 2/9/1997 & 351 & -20.46 & 0.8 & 0.04 & -0.19 & 0.04 & -12.82 & -3.31 & -7.63 & -9.68 & 0.42 & -3.82 & -4.97 & -5.58 & -3.75 & -11.79 & 0.06 & -6.12 & -9.78 & -15.62 \\
\hline \multicolumn{22}{|c|}{ Intermediate semiconfined bedrock aquifer-Plume wells } \\
\hline & & & $\begin{array}{c}\text { Arseno- } \\
\text { lite }\end{array}$ & Barite & Calcite & mite & Gypsum & $\begin{array}{l}\text { Hausman- } \\
\text { nite }\end{array}$ & $\begin{array}{c}\text { Manga- } \\
\text { nite }\end{array}$ & Nsutite & $\begin{array}{c}\text { Pyrolu- } \\
\text { site }\end{array}$ & $\begin{array}{l}\text { Rhodo- } \\
\text { chrosite }\end{array}$ & $\begin{array}{l}\text { Cof- } \\
\text { finite }\end{array}$ & $\begin{array}{l}\text { Ruther- } \\
\text { fordine }\end{array}$ & oepite & Uraninite & $\begin{array}{l}\text { Urano- } \\
\text { phane }\end{array}$ & \multicolumn{4}{|c|}{ Molybdenum solid phases } \\
\hline Well & Date & ORP & $\mathrm{As}_{2} \mathrm{O}_{3}$ & $\mathrm{BaSO}_{4}$ & $\mathrm{CaCO}_{3}$ & $\mathrm{CaMg}\left(\mathrm{CO}_{3}\right)_{2}$ & $\mathrm{CaSO}_{4}: 2 \mathrm{H}_{2} \mathrm{O}$ & $\mathrm{Mn}_{3} \mathrm{O}_{4}$ & $\mathrm{MnOOH}$ & $\mathrm{MnO}_{2}$ & $\mathrm{MnO}_{2}$ & $\mathrm{MnCO}_{3}$ & $\mathrm{USiO}_{4}$ & $\mathrm{UO}_{2} \mathrm{CO}_{3}$ & $\mathrm{UO}_{2}(\mathrm{OH})_{2}: \mathrm{H}_{2} \mathrm{O}$ & $\mathrm{UO}_{2}$ & $\begin{array}{c}\mathrm{Ca}\left(\mathrm{UO}_{2}\right) \\
\left(\mathrm{SiO}_{3} \mathrm{OH}\right)_{2}\end{array}$ & $\mathrm{CaMoO}_{4}$ & $\mathrm{MgMoO}_{4}$ & $\mathrm{Na}_{2} \mathrm{MoO}_{4}$ & $\mathrm{~K}_{2} \mathrm{MoO}_{4}$ \\
\hline 717 & 4/1/1993 & 550 & -- & -- & 0.00 & -0.9 & -0.8 & -4.03 & 0.53 & 0.08 & -1.21 & -0.26 & -21.37 & -7.83 & -7.67 & -20.93 & -16.25 & -- & -- & -- & -- \\
\hline 717 & 2/9/1997 & 25 & -- & -- & 0.05 & -0.85 & -0.82 & -21.44 & -8.17 & -17.45 & -18.83 & -0.21 & -3.99 & -8.23 & -8.00 & -3.56 & -16.76 & -- & -- & -- & -- \\
\hline
\end{tabular}


Table 2. Saturation indices for dissolved arsenic, boron, lead, manganese, mercury, molybdenum, nickel, selenium, uranium, and vanadium data in the upper unconfined alluvial aquifer.-Continued

[ORP, oxidation reduction potential in millivolts; LWR, Little Wind River; <, less than; --, no data]

\begin{tabular}{|c|c|c|c|c|c|c|c|c|c|c|c|c|c|c|c|c|c|c|c|c|c|}
\hline \multicolumn{22}{|c|}{ Little Wind River } \\
\hline & & & $\begin{array}{l}\text { Arseno- } \\
\text { lite }\end{array}$ & Barite & Calcite & Dolomite & Gypsum & $\begin{array}{l}\text { Hausman- } \\
\text { nite }\end{array}$ & $\begin{array}{l}\text { Manga- } \\
\text { nite }\end{array}$ & Nsutite & $\begin{array}{l}\text { Pyrolu- } \\
\text { site }\end{array}$ & $\begin{array}{l}\text { Rhodo- } \\
\text { chrosite }\end{array}$ & $\begin{array}{c}\text { Cof- } \\
\text { finite }\end{array}$ & $\begin{array}{l}\text { Ruther- } \\
\text { fordine }\end{array}$ & Schoepite & Uraninite & $\begin{array}{l}\text { Urano- } \\
\text { phane }\end{array}$ & & lybdenum & Solid Phase & \\
\hline Well & Date & ORP & $\mathrm{As}_{2} \mathrm{O}_{3}$ & $\mathrm{BaSO}_{4}$ & $\mathrm{CaCO}_{3}$ & $\mathrm{CaMg}\left(\mathrm{CO}_{3}\right)_{2}$ & $\mathrm{CaSO}_{4}: 2 \mathrm{H}_{2} \mathrm{O}$ & $\mathrm{Mn}_{3} \mathrm{O}_{4}$ & $\mathrm{MnOOH}$ & $\mathrm{MnO}_{2}$ & $\mathrm{MnO}_{2}$ & $\mathrm{MnCO}_{3}$ & $\mathrm{USiO}_{4}$ & $\mathrm{UO}_{2} \mathrm{CO}_{3}$ & $\mathrm{UO}_{2}(\mathrm{OH})_{2}: \mathrm{H}_{2} \mathrm{O}$ & $\mathrm{UO}_{2}$ & $\begin{array}{c}\mathrm{Ca}\left(\mathrm{UO}_{2}\right) \\
\left(\mathrm{SiO}_{3} \mathrm{OH}_{2}\right)\end{array}$ & $\mathrm{CaMoO}_{4}$ & $\mathrm{MgMoO}_{4}$ & $\mathrm{Na}_{2} \mathrm{MoO}_{4}$ & $\mathrm{~K}_{2} \mathrm{MoO}_{4}$ \\
\hline $\begin{array}{c}\text { LWR } \\
\text { abv }\end{array}$ & & & & & & & & & & & & & & & & & & & & & \\
\hline $\begin{array}{l}\text { Arapa- } \\
\text { hoe, } \\
\text { Wyo. }\end{array}$ & 6/30/1992 & 7.7 & -73.62 & -0.02 & 0.43 & 0.69 & -1.74 & 7.09 & 4.80 & 8.61 & 8.98 & -1.24 & -28.07 & -6.00 & -4.54 & -27.02 & -10.05 & -- & -- & -- & -- \\
\hline $\begin{array}{c}\text { LWR } \\
794\end{array}$ & $5 / 12 / 1998$ & -- & -- & -- & 0.14 & -0.01 & -1.74 & -- & -- & -- & -- & -- & -- & -6.28 & -5.09 & -28.64 & -- & -- & -- & -- & -- \\
\hline $\begin{array}{l}\text { LWR } \\
796\end{array}$ & $5 / 12 / 1998$ & -- & -- & -- & 0.35 & 0.39 & -1.75 & -- & -- & -- & -- & -- & -- & -6.65 & -5.36 & -28.91 & -- & -- & -- & -- & -- \\
\hline
\end{tabular}




\section{Upper Unconfined Alluvial Aquifer}

In the upper unconfined alluvial aquifer, the major ion chemistry among the wells varies slightly, with domestic well 431 and DOE wells 710 and 711 having a predominantly calcium sulfate-bicarbonate composition and DOE wells 724 and 728 having a predominantly calcium bicarbonate composition (fig. 6). Values of $\mathrm{pH}$, specific conductance, and sulfate are similar among the wells (fig. 7). A summary of the available dissolved concentration data for all COCs and COPCs, except sulfate, is given in table 3. Arsenic and molybdenum were detected in about one-half of the samples collected by DOE. There were no detections of boron. Iron was detected in two of the five wells listed in table 3. DOE well 711 had the only uncensored detection of lead and mercury. There were only two detected values of nickel, both occurring in DOE well 711 at a concentration of 20 micrograms per liter $(\mu \mathrm{g} / \mathrm{L})$. Uranium and manganese were detected in almost all samples. Selenium was detected in one sample each in DOE wells 711 and 728, and a few samples of vanadium were detected in each well except domestic well 431. The EPA groundwater-quality standard for uranium of $44 \mu \mathrm{g} / \mathrm{L}$ was not exceeded in any sample. No other COC or COPC detected in any well exceeded any water-quality standard. The groundwater in this aquifer is well oxygenated. All ORP measurements (total of 38 ) in each well were positive indicating oxidizing conditions. In each well, however, there were only one or two measurements in any given year.

PHREEQC modeling of DOE well 710 was done on samples collected on March 11, 1993 (uranium $=4 \mu \mathrm{g} / \mathrm{L}$ ), and May 15, $1998(\operatorname{arsenic}=2.2 \mu \mathrm{g} / \mathrm{L}$, manganese $=7.5$ $\mu \mathrm{g} / \mathrm{L}$, and uranium $=3.8 \mu \mathrm{g} / \mathrm{L}$ ). On March 11, 1993, the groundwater was slightly supersaturated with respect to calcite, in equilibrium with dolomite, and undersaturated with respect to gypsum. On May 15, 1998, the groundwater was in equilibrium with calcite and undersaturated with respect to dolomite and gypsum. On both dates the groundwater was undersaturated with respect to all uranium-bearing minerals, and on May 15, 1998, the groundwater was undersaturated with respect to arsenolite and various solid-phase manganese compounds such as manganite $(\mathrm{MnOOH})$ and rhodochrosite $\left(\mathrm{MnCO}_{3}\right)$. The dissolved uranium on both dates was completely complexed, occurring primarily as $\mathrm{Ca}_{2} \mathrm{UO}_{2}\left(\mathrm{CO}_{3}\right)_{3}$ and $\mathrm{CaUO}_{2}\left(\mathrm{CO}_{3}\right)_{3}^{2-}$. As a result, uranium introduced into this aquifer from the mill would be mobile because of undersaturation with respect to uranium-bearing minerals and because the uranyl carbonate complexes limit adsorption to minerals in the aquifer (Naftz and others, 2011). Arsenic is also completely complexed, existing in the +5 valence state (referred to as arsenate) primarily as $\mathrm{HAsO}_{4}{ }^{2-}$ and secondarily as $\mathrm{H}_{2} \mathrm{AsO}_{4}^{-}$. The existence of arsenic in these species may inhibit the mobility of arsenic in this aquifer because arsenate

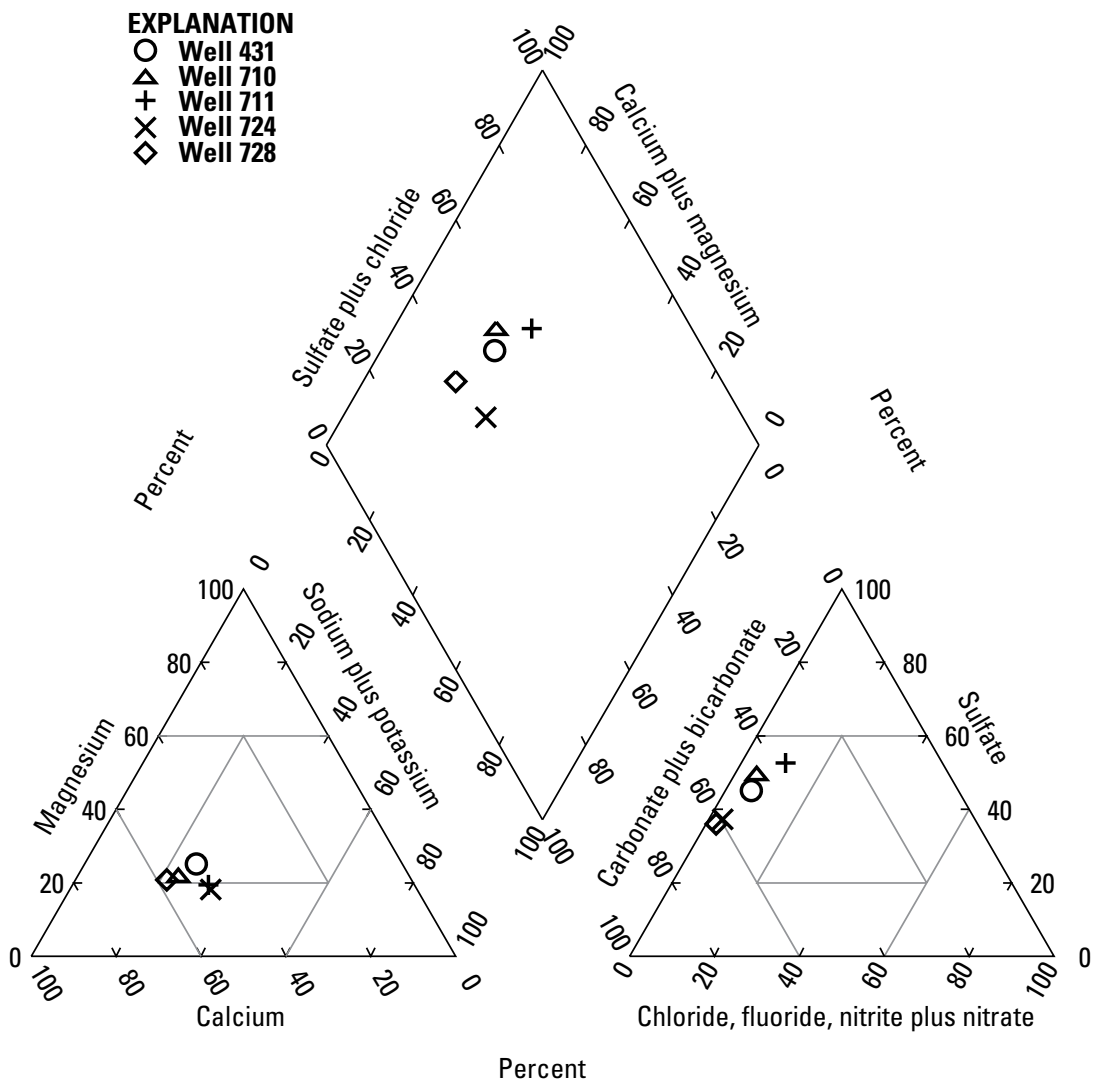

Figure 6. Average major ion chemistry in the upper unconfined alluvial aquifer. 


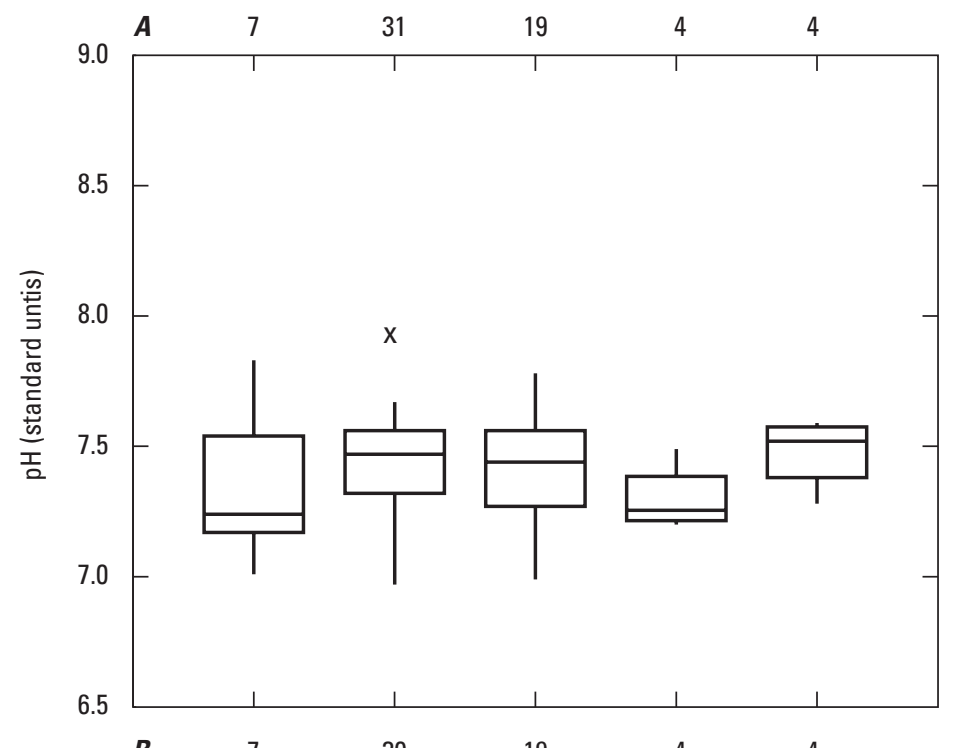

EXPLANATION

Schematic boxplot

30 Number of values

- Upper detached

$x \quad$ Upper outside

Upper adjacent

75th percentile

Median

25th percentile

Lower adjacent

$x$ Lower outside

- Lower detached
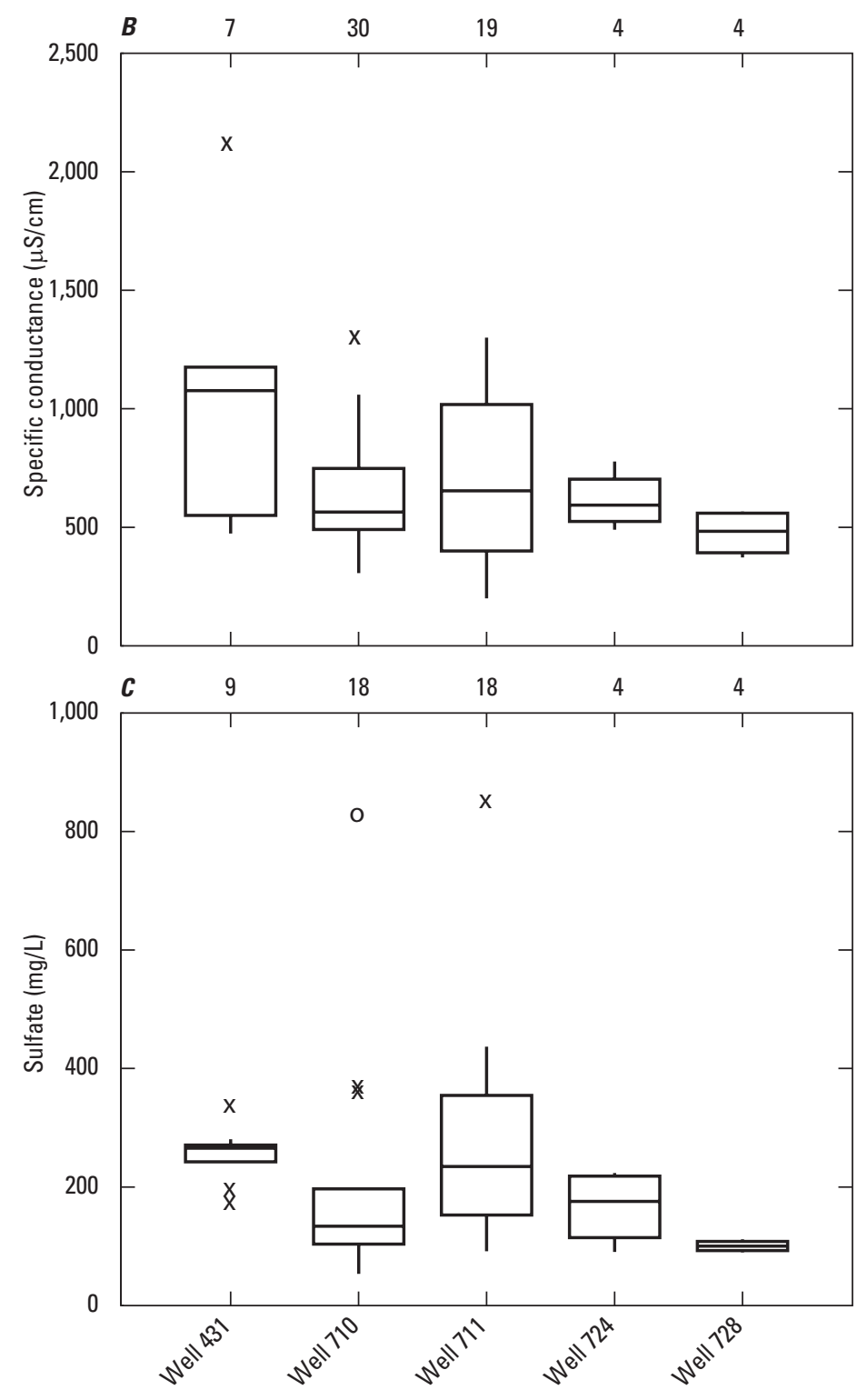

Figure 7. Boxplots of $A, \mathrm{pH} ; B$, specific conductance; and $C$, sulfate in the upper unconfined aquifer. 
Table 3. Summary of dissolved arsenic, boron, lead, manganese, mercury, molybdenum, nickel, selenium, uranium, and vanadium concentration data in the upper unconfined alluvial aquifer.

\begin{tabular}{|c|c|c|c|c|c|c|c|c|c|c|c|}
\hline \multicolumn{12}{|c|}{ Domestic well 431} \\
\hline & Arsenic & Boron & Iron & Lead & Manganese & Mercury & Molybdenum & Nickel & Selenium & Uranium & Vanadium \\
\hline Number of values & 2 & 1 & 2 & 2 & 2 & 2 & 2 & 2 & 2 & 2 & 1 \\
\hline Number of censored values & 2 & 1 & 2 & 2 & 0 & 2 & 2 & 2 & 2 & 0 & 1 \\
\hline (Number of values) detection limits & $(2)<10$ & $(1)<100$ & $(2)<30$ & $(2)<10$ & -- & $(2)<0.2$ & $(2)<10$ & $(2)<40$ & $(2)<5$ & -- & $(1)<10$ \\
\hline Mean & -- & -- & -- & -- & 430 & -- & -- & -- & -- & 9.0 & -- \\
\hline Median & -- & -- & -- & -- & 430 & -- & -- & -- & -- & 9.0 & -- \\
\hline Range of uncensored values & -- & -- & -- & -- & 270 and 590 & -- & -- & -- & -- & 7.7 and 10.3 & -- \\
\hline \multicolumn{12}{|c|}{ DOE well 710} \\
\hline & Arsenic & Boron & Iron & Lead & Manganese & Mercury & Molybdenum & Nickel & Selenium & Uranium & Vanadium \\
\hline Number of values & 16 & 1 & 9 & 7 & 19 & 6 & 19 & 16 & 8 & 19 & 10 \\
\hline Number of censored values & 8 & 1 & 7 & 6 & 10 & 6 & 12 & 16 & 8 & 2 & 6 \\
\hline (Number of values) detection limits & $\begin{array}{l}(5)<5 \\
(3)<10\end{array}$ & $(1)<100$ & $(7)<30$ & $\begin{array}{l}(2)<3 \\
(2)<5 \\
(2)<10\end{array}$ & $\begin{array}{l}\text { (1) }<1.0 \text {; } \\
\text { (1) }<1.1 \text {; } \\
\text { (1) }<1.3 \text {; } \\
\text { (7) }<10.0\end{array}$ & $(6)<0.2$ & $\begin{array}{l}(1)<1.8 \\
(2)<2 \\
(9)<10\end{array}$ & $\begin{array}{c}(1)<0.8 ;(1)<0.9 ; \\
(1)<1 ;(1)<5 ;(1)<7 \text {; } \\
(1)<9 ;(1)<10 ; \\
(1)<10.7 ;(8)<40\end{array}$ & $\begin{array}{l}(1)<2 \text {; } \\
\text { (7) }<5\end{array}$ & $(2)<1$ & $(6)<10$ \\
\hline Mean & 1.99 & -- & -- & -- & 51.5 & -- & 1.78 & -- & -- & 5.8 & 9.8 \\
\hline Median & 1.90 & -- & -- & -- & 1.00 & -- & 1.70 & -- & -- & 4.0 & 5.7 \\
\hline Range of uncensored values & $1.5-3$ & -- & 30 and 30 & 4 & $0.23-910$ & -- & $1.4-2.6$ & -- & -- & $2-15.6$ & $4.5-30$ \\
\hline \multicolumn{12}{|c|}{ DOE well 711} \\
\hline & Arsenic & Boron & Iron & Lead & Manganese & Mercury & Molybdenum & Nickel & Selenium & Uranium & Vanadium \\
\hline Number of values & 17 & 3 & 16 & 15 & 18 & 12 & 18 & 18 & 13 & 17 & 17 \\
\hline Number of censored values & 10 & 3 & 0 & 14 & 0 & 11 & 11 & 16 & 12 & 2 & 13 \\
\hline (Number of values) detection limits & $\begin{array}{l}(4)<5 \text {; } \\
(6)<10\end{array}$ & $(3)<100$ & -- & $\begin{array}{l}(2)<1 \text {; } \\
(2)<3 \text {; } \\
(2)<5 \\
(8)<10\end{array}$ & -- & $\begin{array}{c}(2)<0.1 \\
(9)<0.2\end{array}$ & $(11)<10$ & $\begin{array}{c}(1)<5 ;(1)<7 \text {; } \\
(1)<10 ;(2)<20 \text {; } \\
(11)<40\end{array}$ & $\begin{array}{l}(2)<1 \\
(10)<5\end{array}$ & $\begin{array}{c}(1)<1 \text {; } \\
(1)<3\end{array}$ & $\begin{aligned}(1) & <1 \\
(1) & <4 \\
(11) & <10\end{aligned}$ \\
\hline Mean & 2.54 & -- & 243 & -- & 1,176 & -- & 5.1 & -- & -- & 2.7 & 13.1 \\
\hline Median & 2.0 & -- & 120 & -- & 975 & -- & 3.0 & -- & -- & 2.7 & -- \\
\hline Range of uncensored values & $1.1-7$ & -- & $50-1,560$ & 4 & $520-3,560$ & 0.2 & $1.6-20$ & 20 and 20 & 5 & $0.7-5$ & $20-40$ \\
\hline \multicolumn{12}{|c|}{ DOE well 724} \\
\hline & Arsenic & Boron & Iron & Lead & Manganese & Mercury & Molybdenum & Nickel & Selenium & Uranium & Vanadium \\
\hline Number of values & 4 & -- & 1 & 1 & 4 & -- & 4 & 4 & 1 & 4 & 4 \\
\hline Number of censored values & 2 & -- & 1 & 1 & 0 & -- & 2 & 4 & 1 & 0 & 2 \\
\hline (Number of values) detection limits & $(2)<5$ & -- & $(1)<30$ & $(1)<3$ & -- & -- & $(2)<10$ & $(1)<5$; (1) $<7$; (2) $<40$ & $(1)<5$ & -- & $(2)<10$ \\
\hline Mean & -- & -- & -- & -- & 32.7 & -- & -- & -- & -- & 25.4 & -- \\
\hline Median & 2.9 & -- & -- & -- & 28.5 & -- & 5.45 & -- & -- & 25.4 & 7.65 \\
\hline Range of uncensored values & 2.4 and 3.4 & -- & -- & -- & $3.9-70$ & -- & 4.8 and 6.1 & -- & -- & $19.5-31$ & 7.1 and 8.2 \\
\hline
\end{tabular}


Table 3. Summary of dissolved arsenic, boron, lead, manganese, mercury, molybdenum, nickel, selenium, uranium, and vanadium concentration data in the upper unconfined alluvial aquifer.-Continued

\section{DOE well 728}

\begin{tabular}{|c|c|c|c|c|c|c|c|c|c|c|c|}
\hline & Arsenic & Boron & Iron & Lead & Manganese & Mercury & Molybdenum & Nickel & Selenium & Uranium & Vanadium \\
\hline Number of values & 4 & -- & 1 & 1 & 4 & -- & 4 & 4 & 1 & 4 & 4 \\
\hline Number of censored values & 2 & -- & 1 & 1 & 3 & -- & 2 & 4 & 0 & 0 & 2 \\
\hline (Number of values) detection limits & $(2)<5$ & -- & $(1)<30$ & $(1)<3$ & $(1)<1 ;(2)<10$ & -- & $(2)<10$ & $(1)<5$; (1) $<7$; (2) $<40$ & -- & -- & $(2)<10$ \\
\hline Mean & -- & -- & -- & -- & -- & -- & - & -- & -- & 12.6 & -- \\
\hline Median & 2.40 & -- & -- & -- & 1.45 & -- & 1.9 & -- & -- & 12.6 & 5.5 \\
\hline Range of uncensored values & 2.3 and 2.5 & -- & -- & -- & 1.9 & -- & 1.8 and 2 & -- & 5 & $10.1-15$ & 4.9 and 6.1 \\
\hline
\end{tabular}


sorbs strongly onto iron and aluminum oxyhydroxides and clay minerals (see chaps. 7 and 8 in Frankenberger, 2002). Manganese exists in solution primarily as $\mathrm{Mn}^{2+}$ but also as $\mathrm{MnHCO}_{3}^{+}, \mathrm{MnCO}_{3}$, and $\mathrm{MnSO}_{4}$. At the $\mathrm{pH}$ of the groundwater, the mobility of manganese is controlled more by mineralsolution equilibrium than by sorption reactions, so speciation of manganese is not as important as it is for some of the other COCs and COPCs such as arsenic.

\section{Intermediate Semiconfined Bedrock Aquifer}

Data available for upgradient groundwater wells completed in the intermediate semiconfined bedrock aquifer were limited, but the available data indicate substantial variation among the wells in terms of major ion chemistry, $\mathrm{pH}$, specific conductance, and sulfate concentration. DOE well 725 has a calcium sulfate-bicarbonate composition, DOE well 727 has a sodium sulfate-bicarbonate composition, and DOE well 736 has a calcium sulfate composition (fig. 8). The boxplots of $\mathrm{pH}$, specific conductance, and sulfate concentration include only DOE wells 725 and 727 (fig. 9) because only one sample is available for DOE well 736. This sample had a pH of 7.53, a specific conductance of 852 microsiemens per centimeter $(\mu \mathrm{S} / \mathrm{cm})$, and a sulfate concentration of $368 \mathrm{mg} / \mathrm{L}$.
Concentration data of the COCs and COPCs measured in the wells in this aquifer, other than sulfate, are limited but are similar to each other and to the concentrations measured in the upper unconfined alluvial aquifer (table 4). About onehalf of the samples had measurable amounts of arsenic and molybdenum, but concentrations of arsenic never exceeded $5 \mu \mathrm{g} / \mathrm{L}$, and concentrations of molybdenum never exceeded $3.6 \mu \mathrm{g} / \mathrm{L}$. Mercury was not measured in any sample. Lead, nickel, selenium, and vanadium were never measured above the various detection limits. Uranium was detected in 8 out of 10 samples and did not exceed $9 \mu \mathrm{g} / \mathrm{L}$. The groundwater in this aquifer may become reducing because out of a total of 10 measurements of ORP, one value approached zero $(45 \mathrm{mV})$ and another was negative $(-173 \mathrm{mV})$.

It was not possible to determine the effect of negative redox conditions on the speciation and saturation indices of arsenic and uranium, because major cation data are not available for dates on which the ORP was either negative or close to zero. Therefore, two dates with positive ORP values were selected for input into the model. PHREEQC modeling of DOE well 725 was done on a sample collected on February 7, $1997(\operatorname{arsenic}=1.2 \mu \mathrm{g} / \mathrm{L}$, manganese $=59.8 \mu \mathrm{g} / \mathrm{L}$, and uranium $=8.1 \mu \mathrm{g} / \mathrm{L})$ and DOE well 727 on February 5, $1997($ arsenic $=$ $1.4 \mu \mathrm{g} / \mathrm{L}$, manganese $=27.8 \mu \mathrm{g} / \mathrm{L}$, and uranium $=1 \mu \mathrm{g} / \mathrm{L})$.

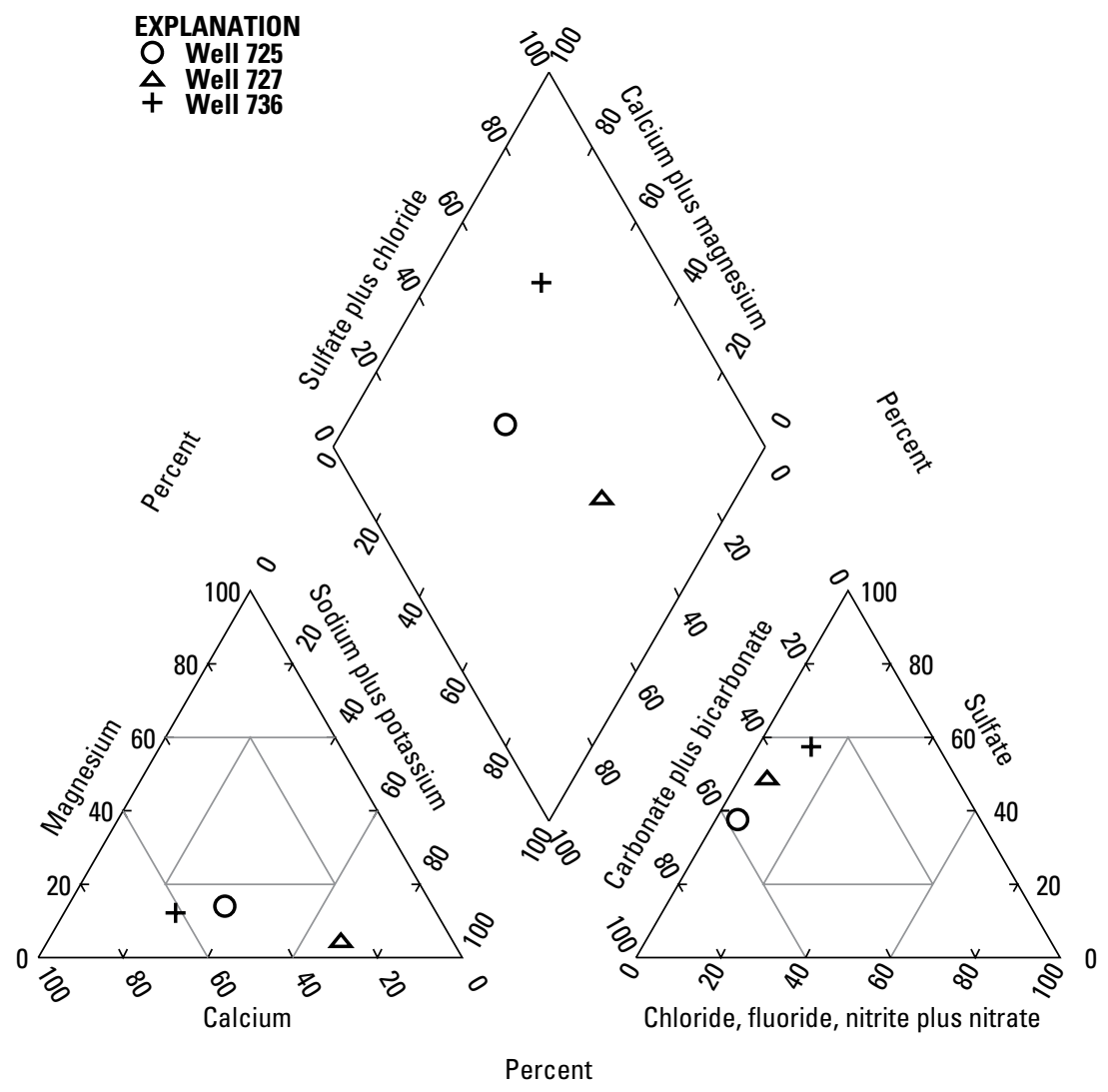

Figure 8. Average major ion chemistry in the semiconfined bedrock aquifer. 


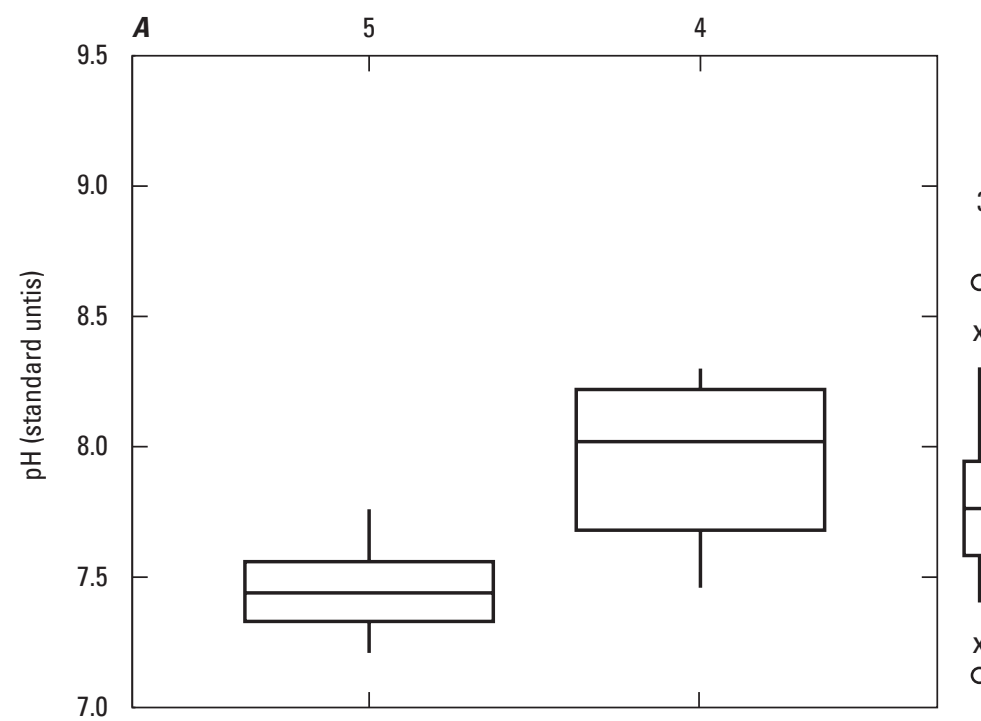

EXPLANATION

Schematic boxplot

30 Number of values

○ Upper detached

$\mathrm{x}$ Upper outside

Upper adjacent

75th percentile

Median

25th percentile

Lower adjacent

$x$ Lower outside

○ Lower detached
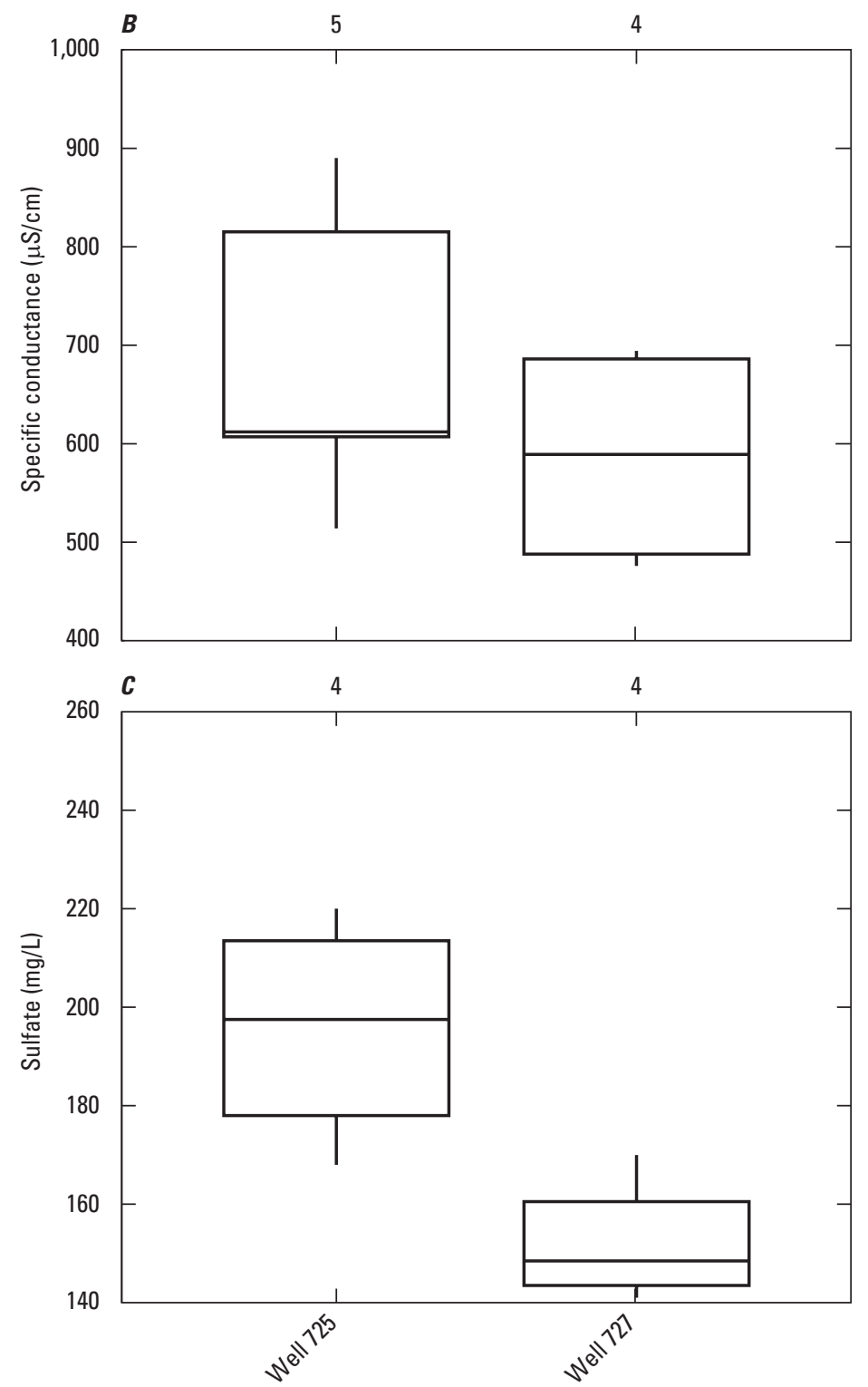

Figure 9. Boxplots of $A, \mathrm{pH} ; B$, specific conductance; and $C$, sulfate in the intermediate semiconfined bedrock aquifer. 
Table 4. Summary of dissolved arsenic, boron, lead, manganese, mercury, molybdenum, nickel, selenium, uranium, and vanadium concentration data in the intermediate semiconfined bedrock aquifer.

\begin{tabular}{|c|c|c|c|c|c|c|c|c|c|c|c|}
\hline \multicolumn{12}{|c|}{ DOE well 725} \\
\hline & Arsenic & Boron & Iron & Lead & Manganese & Mercury & Molybdenum & Nickel & Selenium & Uranium & Vanadium \\
\hline Number of values & 5 & -- & 2 & 1 & 5 & -- & 5 & 5 & 1 & 5 & 5 \\
\hline Number of censored values & 3 & -- & 0 & 1 & 0 & -- & 3 & 5 & 1 & 0 & 5 \\
\hline (Number of values) detection limits & $(3)<5$ & -- & -- & $(1)<3$ & -- & -- & $(3)<10$ & $\begin{array}{l}(1)<5 \\
(1)<7 \\
(3)<40\end{array}$ & $(1)<5$ & -- & $\begin{array}{l}(1)<1 \\
(1)<4 \\
(3)<10\end{array}$ \\
\hline Mean & -- & -- & 55 & -- & 60.3 & -- & - & -- & -- & 7.2 & -- \\
\hline Median & 1.4 & -- & 55 & -- & 60 & -- & 3.6 & -- & -- & 8.0 & -- \\
\hline Range of uncensored values & 1.2 and 1.6 & -- & 40 and 70 & -- & $51.6-70$ & -- & 3.6 and 3.6 & -- & -- & $4.9-9$ & -- \\
\hline \multicolumn{12}{|c|}{ DOE well 727} \\
\hline & Arsenic & Boron & Iron & Lead & Manganese & Mercury & Molybdenum & Nickel & Selenium & Uranium & Vanadium \\
\hline Number of values & 4 & -- & 1 & 1 & 4 & -- & 4 & 4 & 1 & 4 & 4 \\
\hline Number of censored values & 2 & -- & 1 & 1 & 0 & -- & 2 & 4 & 1 & 2 & 4 \\
\hline (Number of values) detection limits & $(2)<5$ & -- & $(1)<30$ & $(1)<3$ & -- & -- & $(2)<10$ & $\begin{array}{l}(1)<5 \\
(1)<7 \\
(2)<40\end{array}$ & $(1)<5$ & $(2)<1$ & $\begin{array}{l}\text { (1) }<1 \\
\text { (1) }<4 \\
\text { (2) }<10\end{array}$ \\
\hline Mean & -- & -- & -- & -- & 19 & -- & -- & -- & -- & -- & -- \\
\hline Median & 1.60 & -- & -- & -- & 20 & -- & 3.5 & -- & -- & 1.0 & -- \\
\hline Range of uncensored values & 1.4 and 1.8 & -- & -- & -- & $8.3-27.8$ & -- & 3.5 and 3.5 & -- & -- & 1 and 2 & -- \\
\hline \multicolumn{12}{|c|}{ DOE well 736} \\
\hline & Arsenic & Boron & Iron & Lead & Manganese & Mercury & Molybdenum & Nickel & Selenium & Uranium & Vanadium \\
\hline Number of values & 1 & -- & 1 & -- & 1 & -- & 1 & 1 & 1 & 1 & 1 \\
\hline Number of censored values & 0 & -- & 0 & -- & 0 & -- & 1 & 1 & 1 & 0 & 1 \\
\hline (Number of values) detection limits & -- & -- & -- & -- & -- & -- & $(1)<10$ & $(1)<40$ & $(1)<5$ & -- & $(1)<10$ \\
\hline Mean & -- & -- & -- & -- & -- & -- & -- & -- & -- & -- & -- \\
\hline Median & -- & -- & -- & -- & -- & -- & -- & -- & -- & -- & -- \\
\hline Range of uncensored values & 5 & -- & 140 & -- & 130 & -- & -- & -- & -- & 5 & -- \\
\hline
\end{tabular}


In both samples the groundwater was slightly undersaturated with respect to dolomite and undersaturated with respect to gypsum, arsenolite, all uranium-bearing minerals, and to various solid-phase manganese compounds such as manganite $(\mathrm{MnOOH})$ and rhodochrosite $\left(\mathrm{MnCO}_{3}\right)$. The only difference in values of saturation indices between the two groundwater wells is that in DOE well 725, the groundwater was slightly saturated with respect to calcite, whereas in DOE well 727 , the groundwater was slightly undersaturated with respect to calcite. In the groundwater sampled from both wells, the dissolved uranium in this aquifer was completely complexed, occurring primarily as $\mathrm{Ca}_{2} \mathrm{UO}_{2}\left(\mathrm{CO}_{3}\right)_{3}$ and secondarily as $\mathrm{CaUO}_{2}\left(\mathrm{CO}_{3}\right)_{3}{ }_{3}^{2-}$. Dissolved arsenic was also completely complexed in the groundwater sampled from both wells, existing in the +5 valence state primarily as $\mathrm{HAsO}_{4}^{2-}$ and secondarily as $\mathrm{H}_{2} \mathrm{AsO}_{4}^{-}$. The existence of arsenic as these species may inhibit the mobility of arsenic in this aquifer as well (Frankenberger, 2002). Dissolved manganese primarily occurred as $\mathrm{Mn}^{2+}$ but also as $\mathrm{MnHCO}_{3}^{+}>\mathrm{MnCO}_{3}>\mathrm{MnSO}_{4}$.

\section{Lower Confined Bedrock Aquifer}

Groundwater in the lower confined bedrock aquifer also exhibited variation among the wells in terms of major ion chemistry (fig. 10), $\mathrm{pH}$, and sulfate concentration (fig. 11) and differed from the groundwater in the intermediate semiconfined bedrock and upper unconfined alluvial aquifers. Values of specific conductance were about equal among the wells in the lower confined bedrock aquifer and in the other two aquifers (fig. 11). The major difference in water quality between this aquifer and the other two was that water in three of the four wells in this aquifer had a sodium sulfate to sodium sulfate-bicarbonate composition, but domestic well 417 had a calcium sulfate-bicarbonate composition. Values of $\mathrm{pH}$ in domestic wells 423 and 430 and DOE well 726 were higher than in groundwater in the other two aquifers. Trace-element data are extremely limited for the wells in the lower confined bedrock aquifer (table 5). No values of arsenic, lead, and selenium were measured above their respective detection limits. Only one value each of mercury and nickel was measured above the detection limit, but the mercury value did not exceed the EPA maximum contaminant level (MCL). Several samples had measurable amounts of molybdenum with the highest concentration being $30 \mu \mathrm{g} / \mathrm{L}$. Vanadium was measured above the detection limit in two wells but did not exceed $20 \mu \mathrm{g} / \mathrm{L}$. Only two concentrations of boron were measured above the detection limit (table 5), but neither value exceeded the State of Wyoming agricultural waterquality standard (table 1). Finally, the majority of samples had measurable amounts of uranium with the highest concentration being $40.5 \mu \mathrm{g} / \mathrm{L}$ in domestic well 417 . The groundwater in this aquifer may also become reducing because one out of six ORP measurements in DOE well 726 was $-268 \mathrm{mV}$ and another had a value of $63 \mathrm{mV}$, but the data were not sufficient to determine if reducing conditions are important. None of the 15 values of ORP measured at domestic well 430 were negative.
PHREEQC modeling of DOE well 726 was done on a sample collected on April 19, 1993 (manganese $=10 \mu \mathrm{g} / \mathrm{L}$ and uranium $=1 \mu \mathrm{g} / \mathrm{L}$ ), and on May 14, 1998 (manganese $=8.8 \mu \mathrm{g} / \mathrm{L}$ and uranium $=1 \mu \mathrm{g} / \mathrm{L}$ ). On both dates the groundwater was undersaturated with respect to gypsum, all uranium-bearing minerals, and various solid-phase manganese compounds such as manganite $(\mathrm{MnOOH})$ and rhodochrosite $\left(\mathrm{MnCO}_{3}\right)$. On April 19, 1993, the groundwater was supersaturated with respect to calcite and dolomite, but on May 14, 1998, the groundwater was slightly undersaturated with respect to these two minerals. On both dates the dissolved uranium was completely complexed, occurring primarily as $\mathrm{CaUO}_{2}\left(\mathrm{CO}_{3}\right)_{3}{ }^{2-}$ but secondarily as $\mathrm{Ca}_{2} \mathrm{UO}_{2}\left(\mathrm{CO}_{3}\right)_{2}$ on April 19 , 1993 , and as $\mathrm{UO}_{2}\left(\mathrm{CO}_{3}\right)_{3}^{4-}$ on May 14, 1998. The speciation of manganese also differed from that in the other two aquifers. On both dates the predominant manganese species was $\mathrm{MnCO}_{3}$, followed by $\mathrm{Mn}^{2+}, \mathrm{MnSO}_{4}$, and $\mathrm{MnHCO}_{3}^{+}$.

Although there is some variability in the major ion composition within and among aquifers, the water quality within each aquifer can be explained on the basis of the weathering reactions of the minerals present in the rocks from which the sediments that make up the Wind River Formation are derived, including calcite, dolomite, gypsum, and quartz (McGreevy and others, 1969). These minerals react with water according to the following equations (Freeze and Cherry, 1979; and Drever, 1988):

Calcite dissolution:

$$
\mathrm{CaCO}_{3}(\mathrm{~s})+\mathrm{CO}_{2}(\mathrm{~g})+\mathrm{H}_{2} \mathrm{O} \leftrightarrow \mathrm{Ca}^{2+}+2 \mathrm{HCO}_{3}^{-}
$$

Dolomite dissolution:

$$
\begin{gathered}
\mathrm{CaMg}\left(\mathrm{CO}_{3}\right)_{2}(\mathrm{~s})+2 \mathrm{CO}_{2}(\mathrm{~g})+2 \mathrm{H}_{2} \mathrm{O} \leftrightarrow \\
\mathrm{Ca}^{2+}+\mathrm{Mg}^{2+}+4 \mathrm{HCO}_{3}^{-}
\end{gathered}
$$

Gypsum dissolution:

$$
\mathrm{CaSO}_{4} \cdot 2 \mathrm{H}_{2} \mathrm{O} \leftrightarrow \mathrm{Ca}^{2+}+\mathrm{SO}_{4}^{2-}+2 \mathrm{H}_{2} \mathrm{O}
$$

Quartz dissolution:

$$
\mathrm{SiO}_{2(\text { quartz) }}+2 \mathrm{H}_{2} \mathrm{O}=\mathrm{H}_{4} \mathrm{SiO}_{4}(\mathrm{aq})
$$

The change in the major ion composition of the groundwater from a calcium bicarbonate-sulfate-water type in the upper unconfined alluvial and intermediate semiconfined bedrock aquifers to a sodium bicarbonate-sulfate-water type in the lower confined bedrock aquifer can be explained, in part, by cation exchange on the surface of clay minerals according to the following equation:

$$
\mathrm{Ca}^{2+}+2 \mathrm{Na} \text { (adsorbed) } \leftrightarrow 2 \mathrm{Na}^{+}+\mathrm{Ca} \text { (adsorbed) }
$$

The reason for the low background concentration of trace elements in the groundwater of each aquifer is not known but may be due to a lack of sulfide minerals relative to the presence of carbonate and sulfate minerals. Sulfide minerals are a major source of trace elements (Drever, 1988), and McGreevy and others (1969) does not mention the presence of sulfide minerals in any of the rocks within the watershed of the Little Wind River. 


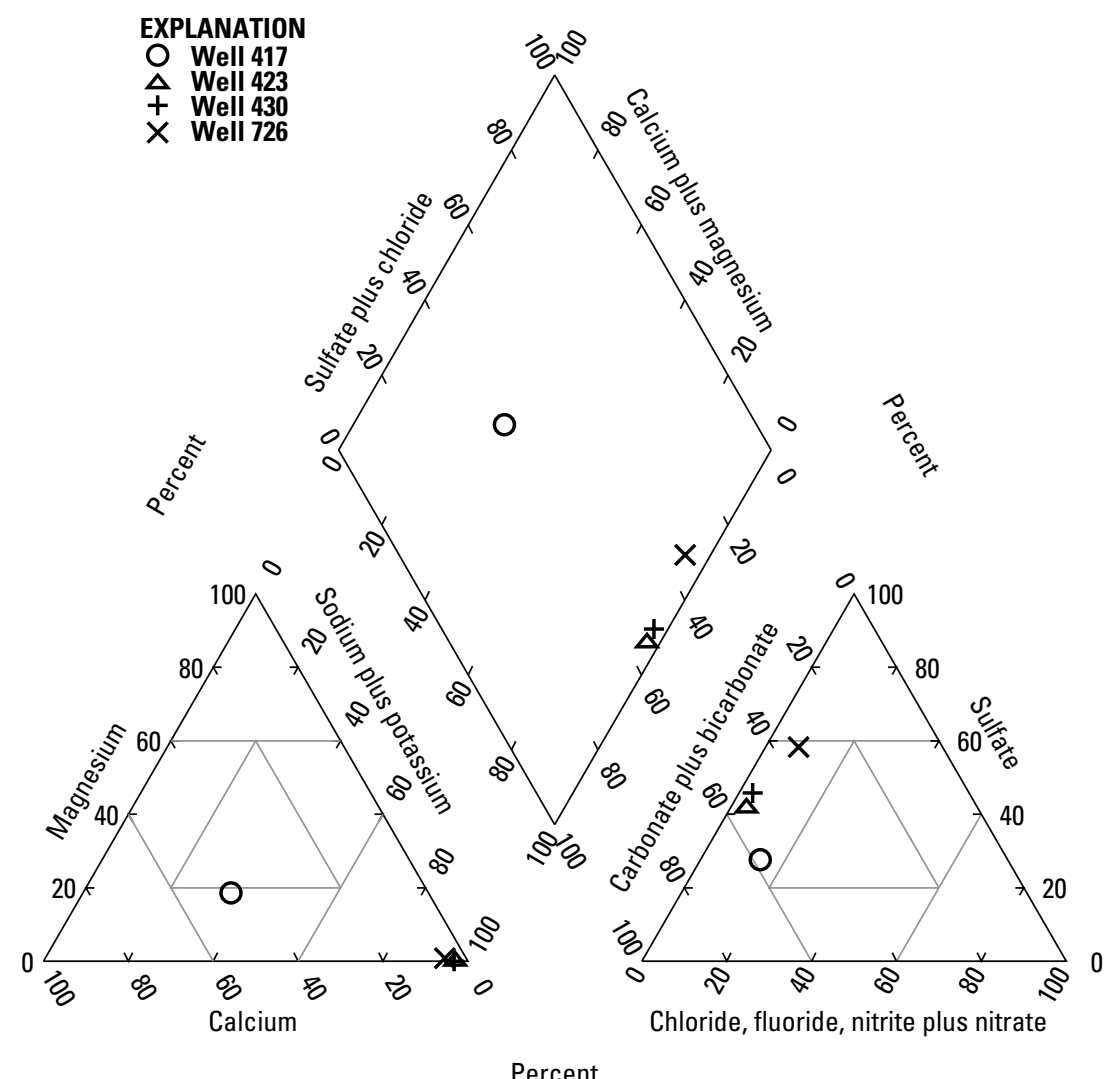

Figure 10. Average major ion chemistry in the lower confined bedrock aquifer.

Groundwater in the upper unconfined alluvial aquifer is oxygenated, and this may be due to the water table being close to the land surface most of the year (within 3-10 feet). Groundwater in the lower two aquifers also seems to be oxygenated, but there were periods when reducing conditions (little to no dissolved oxygen present) may have occurred in each aquifer. The cause of the potential alternating oxidizing and reducing conditions in the lower two aquifers is not known, and there were only one or two redox measurements made each year in each aquifer. More measurements of redox conditions are needed to establish the frequency and duration of reducing conditions. The concentration of all of the COCs and COPCs in groundwater, except for lead and boron, are regulated by redox conditions. Therefore, understanding the frequency, duration, and extent that reducing conditions occur in each aquifer is critical to understanding the fate and transport of the COCs and COPCs. This potential data gap is discussed in more detail in subsequent sections.

Dissolved concentration data for the COCs and COPCs in each aquifer are somewhat limited, but some general conclusions can be made with the available data collected from wells chosen to represent background water-quality conditions. Other than manganese and uranium, all of the other COCs and COPCs were detected in less than one-half of the samples collected in each aquifer. The EPA groundwater-quality standard for uranium of $44 \mu \mathrm{g} / \mathrm{L}$ (http:// www.gpo.gov/fdsys/pkg/CFR-2012-title40-vol26/pdf/CFR2012-title40-vol26-part192-subpartA-app1.pdf) was not exceeded in any sample. No other COC or COPC in any well exceeded any water-quality standard. The mobility of arsenic, manganese, and uranium appears to be similar in each aquifer. Although there was some variability in the degree of saturation with respect to calcite and dolomite within and among aquifers, the groundwater in each aquifer is consistently undersaturated with respect to gypsum and various mineral phases containing arsenic, manganese, and uranium and is saturated with respect to quartz. The speciation in each aquifer is nearly identical, although the major difference is the presence of $\mathrm{MnCO}_{3}$ as the major manganese species in the lower confined bedrock aquifer. The speciation and saturation index data indicate that manganese and uranium introduced into each of the aquifers from the former uranium processing facility would be mobile. Arsenic most likely is not as mobile as manganese and uranium because, although it is undersaturated with respect to arsenolite, it exists in solution primarily in the +5 oxidation state and is likely to sorb to aquifer materials (Frankenberger, 2002). 
22 Assessment of Groundwater and Little Wind River, Wind River Reservation, Wyoming, 1987-2010

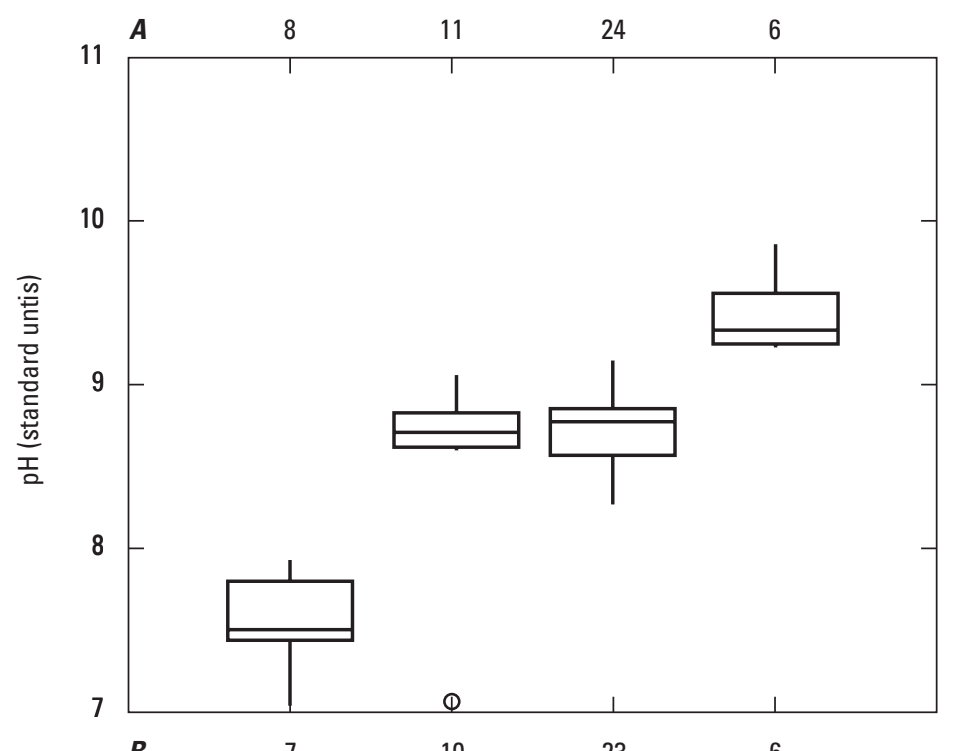

EXPLANATION

Schematic boxplot

30 Number of values

○ Upper detached

$\mathrm{x}$ Upper outside

Upper adjacent

75th percentile

Median

25th percentile

Lower adjacent

$x$ Lower outside

- Lower detached
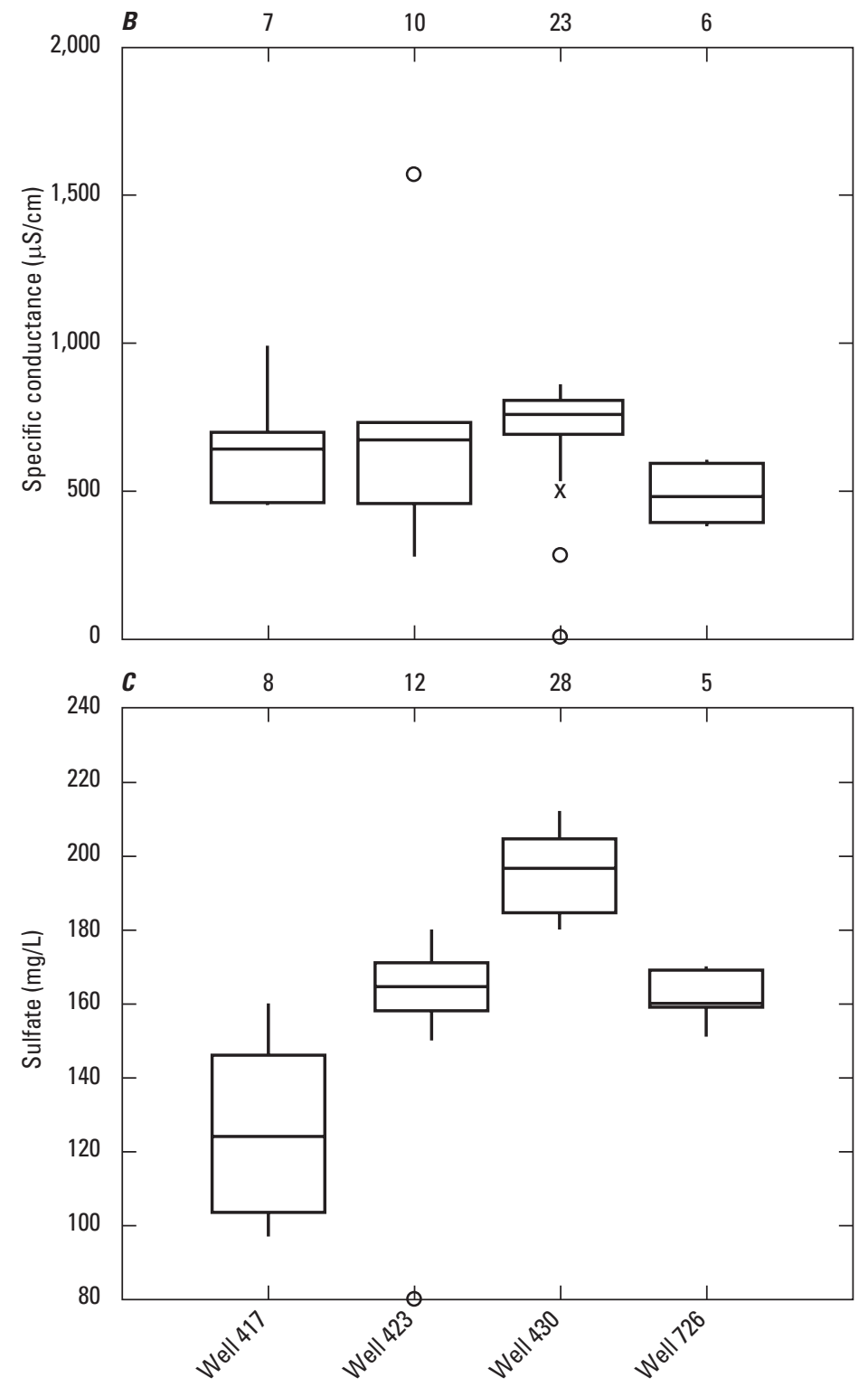

Figure 11. Boxplots of $A, \mathrm{pH} ; B$, specific conductance; and $C$, sulfate in the lower confined bedrock aquifer. 
Table 5. Summary of dissolved arsenic, boron, lead, manganese, mercury, molybdenum, nickel, selenium, uranium, and vanadium concentration data in the lower confined bedrock aquifer.

\begin{tabular}{|c|c|c|c|c|c|c|c|c|c|c|c|}
\hline \multicolumn{12}{|c|}{ Domestic well 417} \\
\hline & Arsenic & Boron & Iron & Lead & Manganese & Mercury & Molybdenum & Nickel & Selenium & Uranium & Vanadium \\
\hline Number of values & 2 & -- & 3 & 2 & 2 & 2 & 2 & 2 & 2 & 2 & 3 \\
\hline Number of censored values & 2 & -- & 0 & 2 & 0 & 2 & 1 & 2 & 2 & 0 & 1 \\
\hline (Number of values) detection limits & $(2)<10$ & -- & - & $(2)<10$ & -- & $(2)<0.2$ & $(1)<10$ & $(2)<40$ & $(2)<5$ & -- & $(1)<10$ \\
\hline Mean & -- & -- & 243 & -- & 105 & -- & -- & -- & -- & 29.8 & -- \\
\hline Median & -- & -- & 270 & -- & 105 & -- & -- & -- & -- & 29.8 & 9 \\
\hline Range of uncensored values & -- & -- & $110-350$ & -- & 80 and 130 & -- & 30 & -- & -- & 19 and 40.5 & 9 and 10 \\
\hline \multicolumn{12}{|c|}{ Domestic well 423} \\
\hline & Arsenic & Boron & Iron & Lead & Manganese & Mercury & Molybdenum & Nickel & Selenium & Uranium & Vanadium \\
\hline Number of values & 5 & 6 & 5 & 5 & 5 & 5 & 5 & 5 & 5 & 5 & 4 \\
\hline Number of censored values & 5 & 6 & 0 & 5 & 5 & 4 & 4 & 5 & 5 & 2 & 3 \\
\hline (Number of values) detection limits & $(5)<10$ & $(6)<100$ & - & $(5)<10$ & $(5)<10$ & $(4)<0.2$ & $(4)<10$ & $(5)<40$ & $(5)<5$ & $(2)<0.3$ & $(3)<10$ \\
\hline Mean & -- & -- & 56 & -- & -- & -- & -- & -- & -- & 1.1 & -- \\
\hline Median & -- & -- & 60 & -- & -- & -- & -- & -- & -- & 0.5 & -- \\
\hline Range of uncensored values & -- & -- & $30-70$ & -- & -- & 0.5 & 10 & -- & -- & $0.5-3$ & 20 \\
\hline \multicolumn{12}{|c|}{ Domestic well 430} \\
\hline & Arsenic & Boron & Iron & Lead & Manganese & Mercury & Molybdenum & Nickel & Selenium & Uranium & Vanadium \\
\hline Number of values & 6 & 2 & 7 & 6 & 6 & 8 & 7 & 6 & 6 & 6 & 5 \\
\hline Number of censored values & 6 & 0 & 2 & 6 & 5 & 8 & 6 & 5 & 6 & 3 & 5 \\
\hline (Number of values) detection limits & $\begin{array}{l}\text { (1) }<1 \text {; } \\
(1)<5 \\
\text { (4) }<10\end{array}$ & -- & $\begin{array}{c}(1)<30 \\
(1)<40\end{array}$ & $(6)<10$ & $(5)<10$ & $(8)<0.2$ & $\begin{array}{l}(1)<1 \text {; (1) }<4 \text {; } \\
(1)<5 \text {; }(3)<10\end{array}$ & $(5)<40$ & $\begin{array}{l}(1)<2 \text {; } \\
(5)<5\end{array}$ & $\begin{array}{l}(2)<0.3 \text {; } \\
\text { (1) }<2\end{array}$ & $\begin{array}{l}(2)<4 \\
(3)<10\end{array}$ \\
\hline Mean & -- & 140 & 123 & -- & -- & -- & -- & -- & -- & 0.8 & -- \\
\hline Median & -- & 140 & 70 & -- & -- & -- & -- & 17 & -- & 0.6 & -- \\
\hline Range of uncensored values & -- & 100 and 180 & $50-530$ & -- & 20 & -- & 10 & 17 & -- & $0.6-2$ & -- \\
\hline \multicolumn{12}{|c|}{ DOE well 726} \\
\hline & Arsenic & Boron & Iron & Lead & Manganese & Mercury & Molybdenum & Nickel & Selenium & Uranium & Vanadium \\
\hline Number of values & 5 & -- & 2 & 1 & 5 & -- & 5 & 5 & 1 & 5 & 5 \\
\hline Number of censored values & 5 & -- & 2 & 1 & 0 & -- & 3 & 5 & 1 & 4 & 5 \\
\hline (Number of values) detection limits & $\begin{array}{c}(1)<0.2 \\
(1)<1 \\
(3)<5\end{array}$ & -- & $(2)<30$ & $(1)<3$ & -- & -- & $(3)<10$ & $\begin{array}{l}(1)<5 \\
(1)<7 \\
(3)<40\end{array}$ & $(1)<5$ & $(4)<1$ & $\begin{array}{l}\text { (1) }<1 \\
\text { (1) }<4 \\
\text { (3) }<10\end{array}$ \\
\hline Mean & -- & -- & -- & -- & 9.6 & -- & -- & -- & -- & -- & -- \\
\hline Median & -- & -- & -- & -- & 10 & -- & 2.8 & -- & -- & -- & -- \\
\hline Range of uncensored values & -- & -- & -- & -- & $8.8-10$ & -- & 2.7 and 2.9 & -- & -- & 1 & -- \\
\hline
\end{tabular}




\section{Seasonal Variations in Directions of Groundwater Flow in the Area of the Former Uranium Processing Mill}

Data collected by the DOE indicate that groundwater beneath the site of the former uranium processing mill, where the sulfuric-acid plant exists today, flows from the former mill site southeast to the Little Wind River (fig. 4). The WREQC is concerned that seasonal canal diversions for irrigation (May or June through late July to early September) from the Wind River upgradient from the UMTRA site may affect groundwater-flow directions and that groundwater in the upper unconfined alluvial aquifer with elevated concentrations of uranium may flow north into the Wind River. A groundwater divide probably exists between the Wind River and the Little Wind River. If the groundwater elevation contours shown in figure 4 extend to the Wind River and Little Wind River, then the groundwater divide lies to the northwest of DOE well 710, and in the area of the UMTRA site, the Wind River is a losing stream and the Little Wind River is a gaining stream. In that case, for a reversal of groundwater flow to induce contaminants to flow from the UMTRA site to the Wind River, the hydraulic gradient would have to reverse all the way from DOE well 710 to the Wind River, and groundwater would have to flow about 3,000 feet northwest of DOE well 710 to enter the Wind River. For this to occur, water elevations in DOE well 710 would have to decline below those in the contaminated wells downgradient from it.

Therefore, the seasonal variation in directions of groundwater flow was evaluated by comparing groundwater elevations in DOE wells 710, 101, 728, 716, 722R, and 707 (fig. 12) and uranium and sulfate concentrations in DOE wells 710,711 , and 101 for the period of record (fig. 13). These wells lie along the axis of the flow path in the upper unconfined alluvial aquifer delineated by the DOE (U.S. Department of Energy, 1995) and with the exception of DOE wells 710 and 711, which are uncontaminated wells upgradient from the site of the former mill tailings pile, all are contaminated with uranium and other COCs and COPCs. Figure 12 indicates a consistent hydraulic gradient from the upgradient well 710 toward the southeast along DOE wells $728,101,722 \mathrm{R}$, and 716 to 707 for the entire period of record. The concentration of uranium and sulfate in upgradient DOE wells 710 and 711 (an abandoned well north of DOE well 710) was compared with the concentration of uranium in the nearest contaminated well, which is DOE well 101 (fig. 13). The concentration of uranium and sulfate in DOE well 101 is greater than that in DOE wells 710 and 711. In the uranium boxplot, all nondetects were censored to the highest detection limit of $3 \mu \mathrm{g} / \mathrm{L}$ and are shown on the plot as this concentration. Both the groundwater elevation and concentration data indicate no evidence of a reversal of groundwater flow from the UMTRA site toward the Wind River.

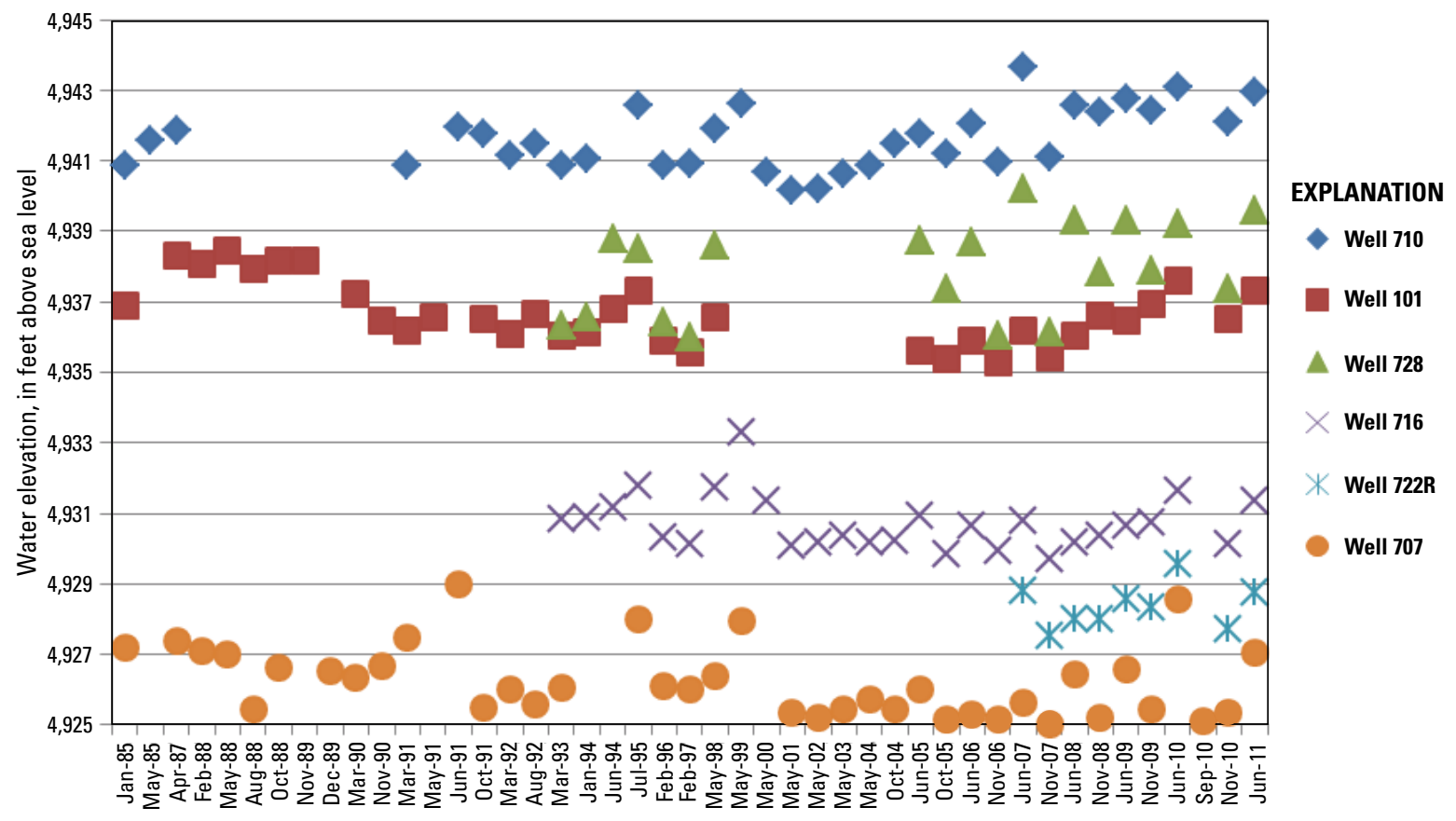

Figure 12. Hydrograph of groundwater elevation for U.S. Department of Energy wells $710,101,728,716,722 \mathrm{R}$, and 707 for the period of record. 


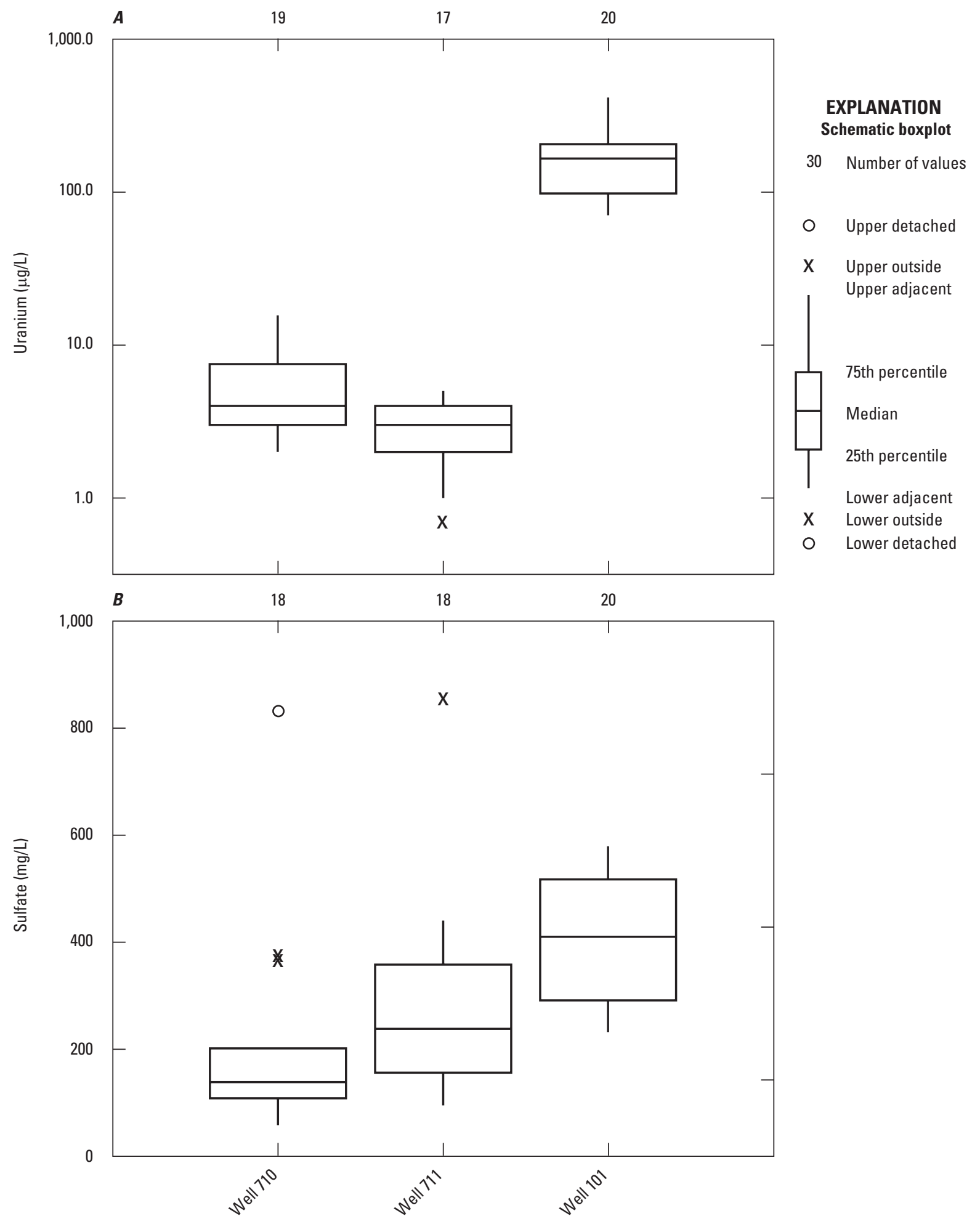

Figure 13. Boxplots of $A$, dissolved uranium and $B$, sulfate concentrations in U.S. Department of Energy wells 710 , 711 , and 101 for the period of record. 


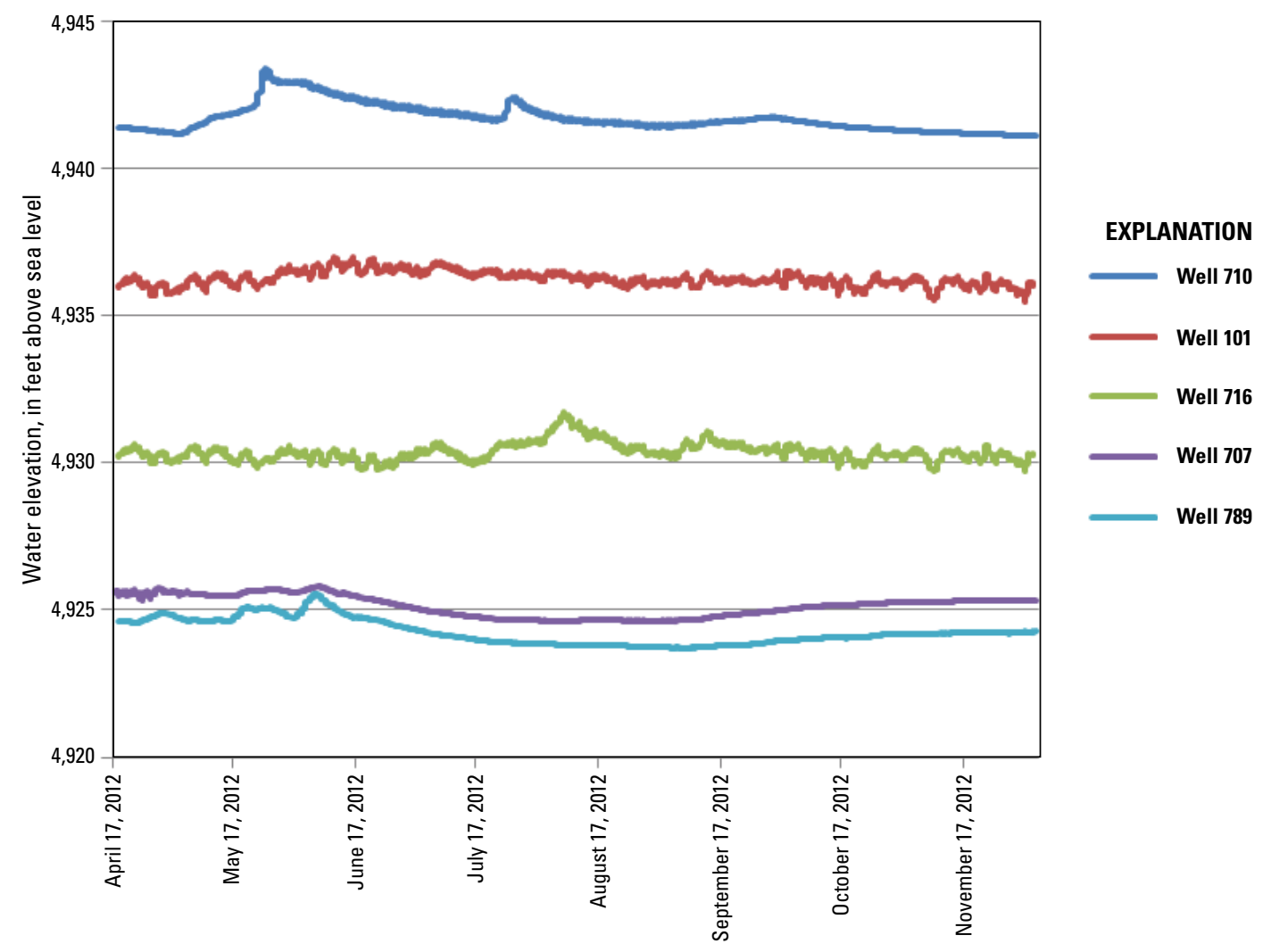

Figure 14. Hydrograph of DOE wells $710,101,716,707$, and 789 based on pressure transducer data

Data reviewed to determine seasonal variations in the direction of flow revealed that groundwater elevations were measured only twice per year, once in June and once in November, for most of the period of record. Therefore, seasonal variability in groundwater elevations are not well defined. The DOE addressed this data gap by installing pressure transducers in wells $710,101,716,707$, and 789 that measured groundwater elevation every 4 hours from April into early December 2012 (William Dam, U.S. Department of Energy, written commun., 2012) (fig. 14). These data clearly indicate a consistent hydraulic gradient from the former mill site toward the southeast.

\section{Extent of Contaminated Groundwater Among the Three Aquifers}

The extent of contaminated groundwater was evaluated by comparing groundwater elevations (fig. 15), major ion chemistry (figs. 16-24), and the median concentrations of manganese, molybdenum, sulfate, and uranium in nested DOE wells (figs. 25-28). DOE groundwater wells shown in figure 2 have leading zeros, which are dropped for expediency in the report. The following 11 groups of nested DOE monitoring wells are used in this evaluation:
- Wells 724 (upper unconfined alluvial aquifer), 725 (intermediate semiconfined bedrock aquifer), and 726 (lower confined bedrock aquifer). These wells are located north of the former tailings pile and are representative of background groundwater quality.

- Wells 101 (upper unconfined alluvial aquifer), 111 (intermediate semiconfined bedrock aquifer), and 110 (lower confined bedrock aquifer). These wells are located at the former mill site and are at the head of the contaminated plume of groundwater.

- Wells 784 (upper unconfined alluvial aquifer) and 732 (intermediate semiconfined bedrock aquifer). These wells are located southwest of DOE wells 101, 111, and 110 adjacent to West Side Creek (fig. 2).

- Wells 716 (upper unconfined alluvial aquifer) and 717 (intermediate semiconfined bedrock aquifer). These wells are located within the contaminated groundwater plume downgradient from DOE wells 101, 111, and 110.

- Wells 722R (upper unconfined alluvial aquifer) and 723 (intermediate semiconfined bedrock aquifer). These wells are located within the contaminated groundwater plume downgradient from DOE wells 716 and 717. 
- Wells 707 (upper unconfined alluvial aquifer), 705 (intermediate semiconfined bedrock aquifer), and 709 (lower confined bedrock aquifer). These wells are located within the contaminated groundwater plume adjacent to the north bank of the Little Wind River.

- Wells 706 (upper unconfined alluvial aquifer) and 735 (intermediate semiconfined bedrock aquifer). These wells are located on the south bank of the Little Wind River south of nested DOE wells 707, 705, and 709.

- Wells 718 (upper unconfined alluvial aquifer) and 719 (intermediate semiconfined bedrock aquifer). These wells are located adjacent to route 137 (Rendezvous Road) west of DOE wells $722 \mathrm{R}$ and 723.

- Wells 729 (upper unconfined alluvial aquifer) and 730 (intermediate semiconfined bedrock aquifer). These wells are located adjacent to route 137 (Rendezvous Road) east of DOE wells 722R and 723.

- Wells 720 (upper unconfined alluvial aquifer) and 721 (intermediate semiconfined bedrock aquifer). These wells are located adjacent to route 137 (Rendezvous Road) west of DOE wells 718 and 719.

- Wells 733 (upper unconfined alluvial aquifer) and 734 (intermediate semiconfined bedrock aquifer). These wells are located at the southwest edge of the UMTRA site adjacent to the north side of the Little Wind River near DOE sampling site 794 on the Little Wind River.

In the following discussion, median values are used for the COCs in figures 25-28 and average values of the major ions are used in the Piper diagrams (figs. 16-24). Median values for the COCs are used because of values recorded below the detection limit in samples collected from many of the groundwater wells. It is possible to calculate a median value with values below the detection limit but not an average value (Helsel and Hirsch, 1992). None of the major ions were recorded as below the detection limit so average values were used. An assessment of whether concentrations of manganese, molybdenum, sulfate, and uranium were above background in a particular well was made by comparing the median concentration of a COC measured in a well against a threshold value that was determined from the data presented in the "Background Concentrations of the Contaminants of Concern" section. Based on that data, it was decided that if the median concentration of manganese, molybdenum, sulfate, and uranium was greater than $400 \mu \mathrm{g} / \mathrm{L}, 20 \mu \mathrm{g} / \mathrm{L}$, $400 \mathrm{mg} / \mathrm{L}$, and $30 \mu \mathrm{g} / \mathrm{L}$, respectively, it was reasonable to conclude that the COC was present at above-background concentrations. In the first sentence of each subsection of this section of the report, a $U$ (upper unconfined alluvial aquifer), I (intermediate semiconfined bedrock aquifer), and L (lower confined bedrock aquifer) was placed adjacent to the appropriate well to make it easier for the reader to keep track of the well location.
DOE wells 724, 725, and 726. The hydrograph for DOE wells 724 (U), 725 (I), and 726 (L), shows that the water elevations in the well completed in the lower confined bedrock aquifer (726) are consistently above the well completed in the intermediate semiconfined bedrock aquifer (725) and in the upper unconfined alluvial aquifer (724) (fig. 15A). This indicates a potential for groundwater to move from the lower confined bedrock aquifer into the upper aquifers, but groundwater in the upper two aquifers cannot flow into the lower aquifer. Conversely, the water elevations for DOE wells 724 and 725 are about equal on each date indicating that no or perhaps limited water exchange can occur between these two aquifers.

These observations are supported by the major ion composition of the groundwater (fig. 16). The composition of the water in DOE wells 724 and 725 is almost identical, whereas the water in DOE well 726 is distinct from the other two wells. The nearly identical major ion composition in DOE wells 724 and 725 could result from identical reactions occurring in each aquifer or as a result of some degree of mixing occurring between these two aquifers at this location. The well logs indicate that the confining layer between the upper unconfined alluvial aquifer and the intermediate semiconfined bedrock aquifer at this location consists of 4 feet of highly weathered shale and clay. So it is plausible that this confining unit is permeable enough to allow mixing of these two aquifers to occur or, perhaps more accurately, it allows these two aquifers to act as one aquifer at this location. Although the hydrograph indicates the potential for water in the lower confined bedrock aquifer to mix with water in the intermediate semiconfined bedrock aquifer, the distinct major ion chemistry of the lower confined bedrock is evidence of a lack of mixing of water in this aquifer with the aquifer above it. The reason for the lack of mixing is the presence of a confining layer between these two aquifers consisting of 37 feet of hard, dark-gray shale.

Finally, the median concentration plots of the COCs indicate relatively low concentrations of manganese, molybdenum, sulfate, and uranium in each aquifer, with the lowest median concentration of each of these COCs consistently occurring in the lower confined bedrock aquifer (figs. 25-28). Therefore, the concentration of these COCs in these wells is considered to be representative of background conditions.

DOE wells 101, 111, and 110. The hydrograph for DOE wells $101(\mathrm{U}), 111(\mathrm{I})$, and $110(\mathrm{~L})$ indicates a more complex situation than at the location of DOE wells 724,725 , and 726 (fig. 15A). On dates when water elevations were measured in all three wells, the water elevations in DOE well 111 are consistently above both wells, and the water elevations in DOE well 101 are consistently above DOE well 110 but below DOE well 111. As a result, there is the potential for groundwater in the intermediate semiconfined bedrock aquifer to flow into the aquifers above and below it, but groundwater in the upper unconfined alluvial aquifer cannot flow into either of the lower two aquifers. The consistently low water elevations in DOE well 110 relative to the DOE wells 101 
$\boldsymbol{A}$

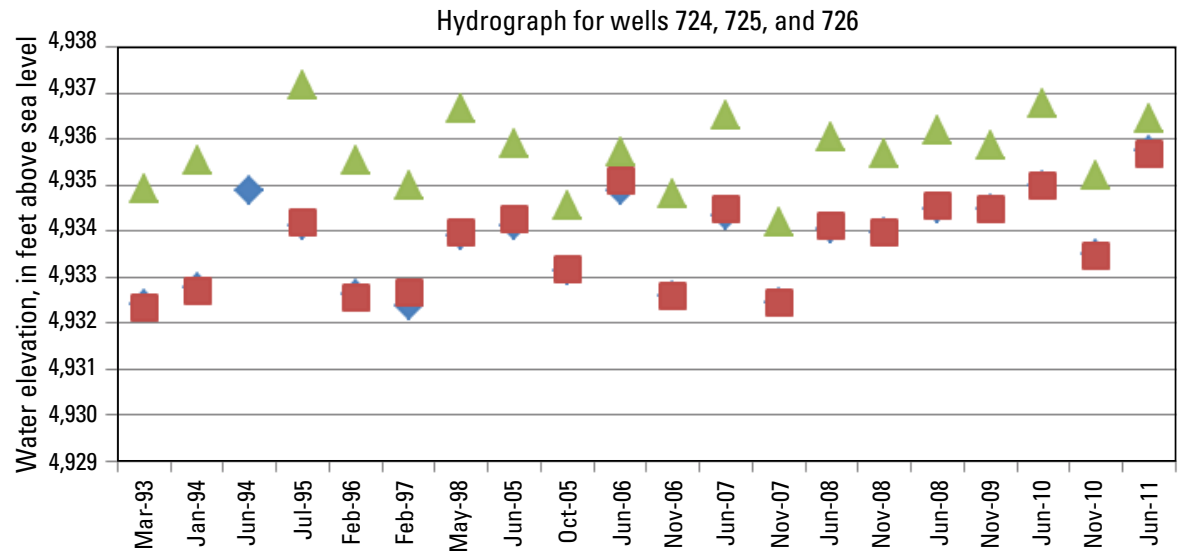

EXPLANATION

Well 724

Well 725

Well 726

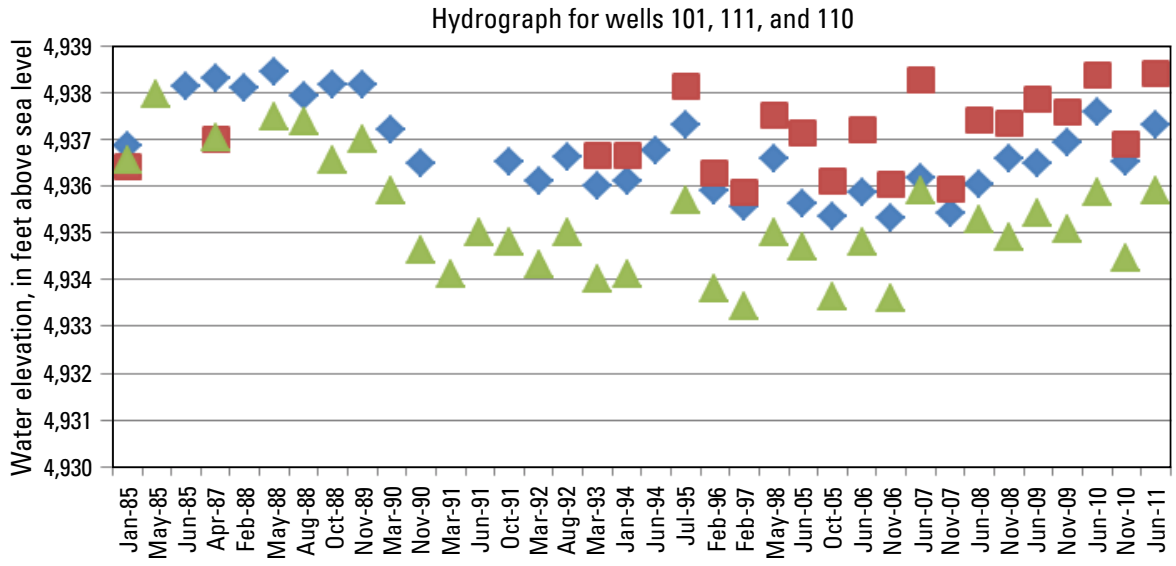

EXPLANATION

$\diamond$ Well 101

Well 111

$\Delta$ Well 110

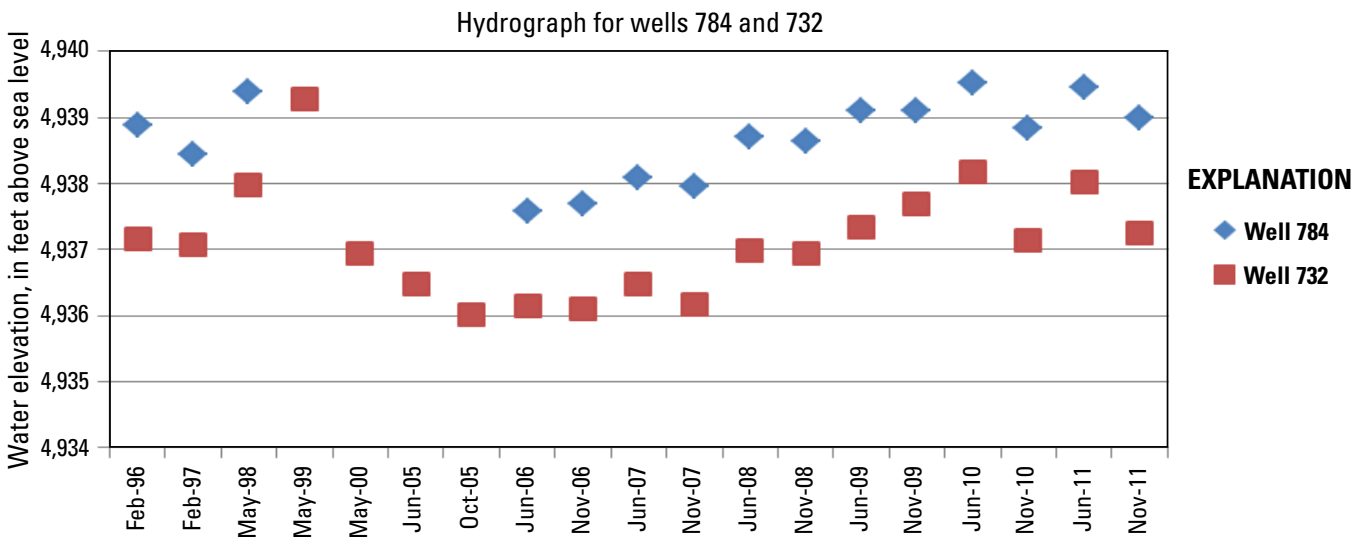

Figure 15. Hydrographs of groundwater elevation for nested U.S. Department of Energy monitoring wells for the period of record: $A$, Wells 724, 725, 726, 101, 111,110, 784, and 732; $B$, Wells 716, 717, 722R, 723, 707,705, and 709; C, Wells 706, 735, 718, 719, 729, and 730; and $D$, Wells 720, 721, 733, and 734. 
B
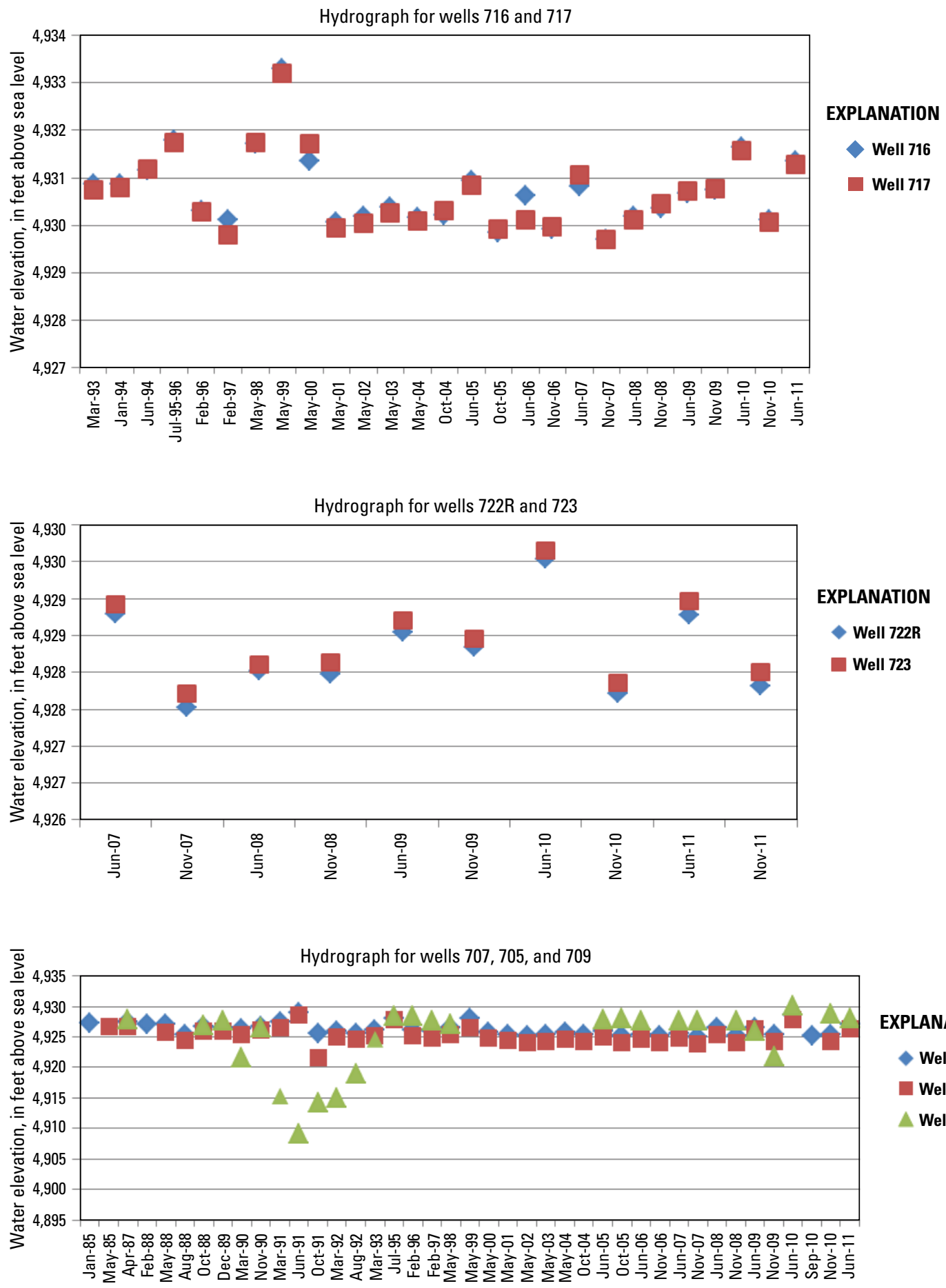

EXPLANATION

$\checkmark$ Well 707

Well 705

$\triangle$ Well 709

Figure 15. Hydrographs of groundwater elevation for nested U.S. Department of Energy monitoring wells for the period of record: $A$, Wells 724, 725, 726, 101, 111,110, 784, and 732; $B$, Wells 716, 717, 722R, 723, 707,705, and 709; $C$, Wells 706, 735, 718, 719, 729, and 730; and $D$, Wells 720, 721, 733, and 734.-Continued 
C

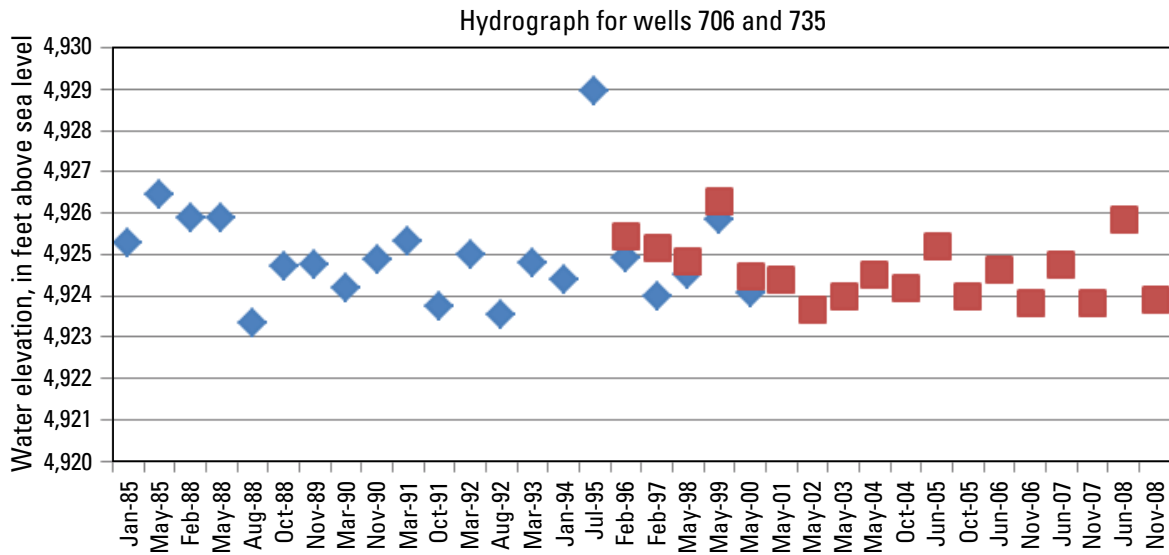

EXPLANATION

Well 706

Well 735

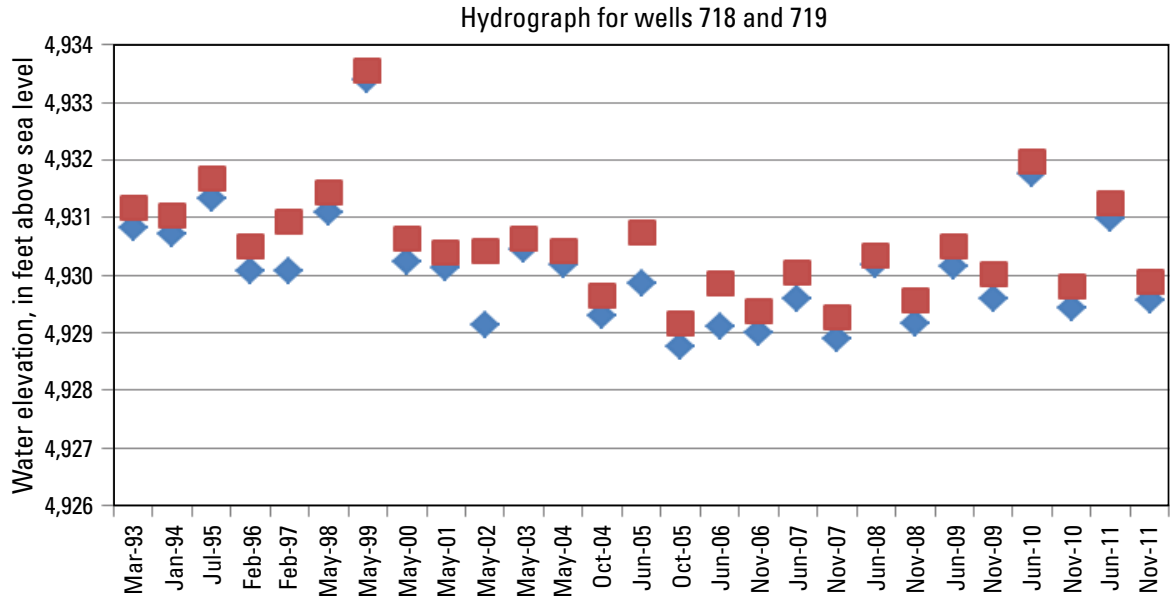

EXPLANATION

Well 718

Well 719

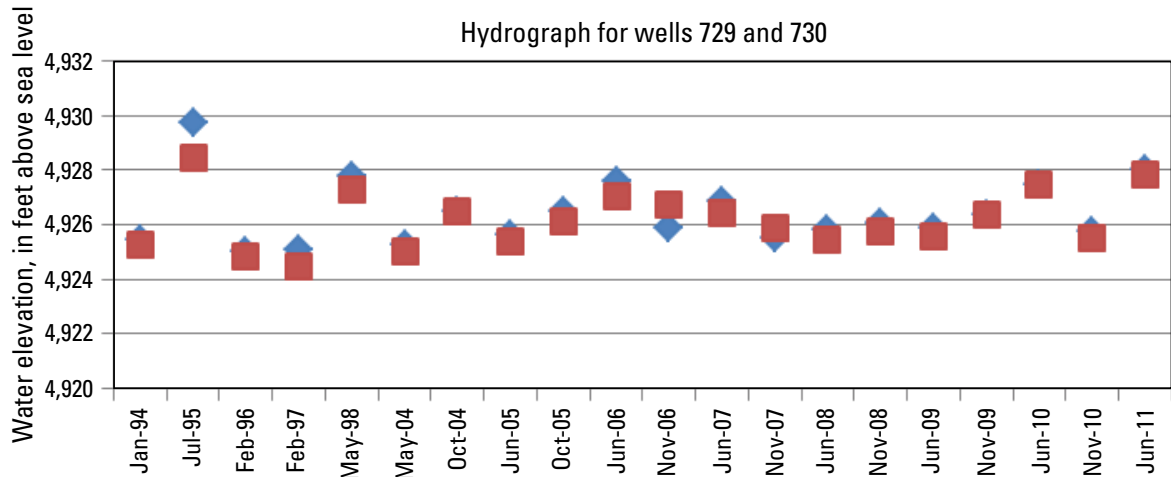

EXPLANATION

Well 729

Well 730

Figure 15. Hydrographs of groundwater elevation for nested U.S. Department of Energy monitoring wells for the period of record: $A$, Wells 724, 725, 726, 101, 111,110, 784, and 732; $B$, Wells 716, 717, 722R, 723,

707,705, and 709; $C$, Wells 706, 735, 718, 719, 729, and 730; and $D$, Wells 720, 721, 733, and 734.-Continued 
D
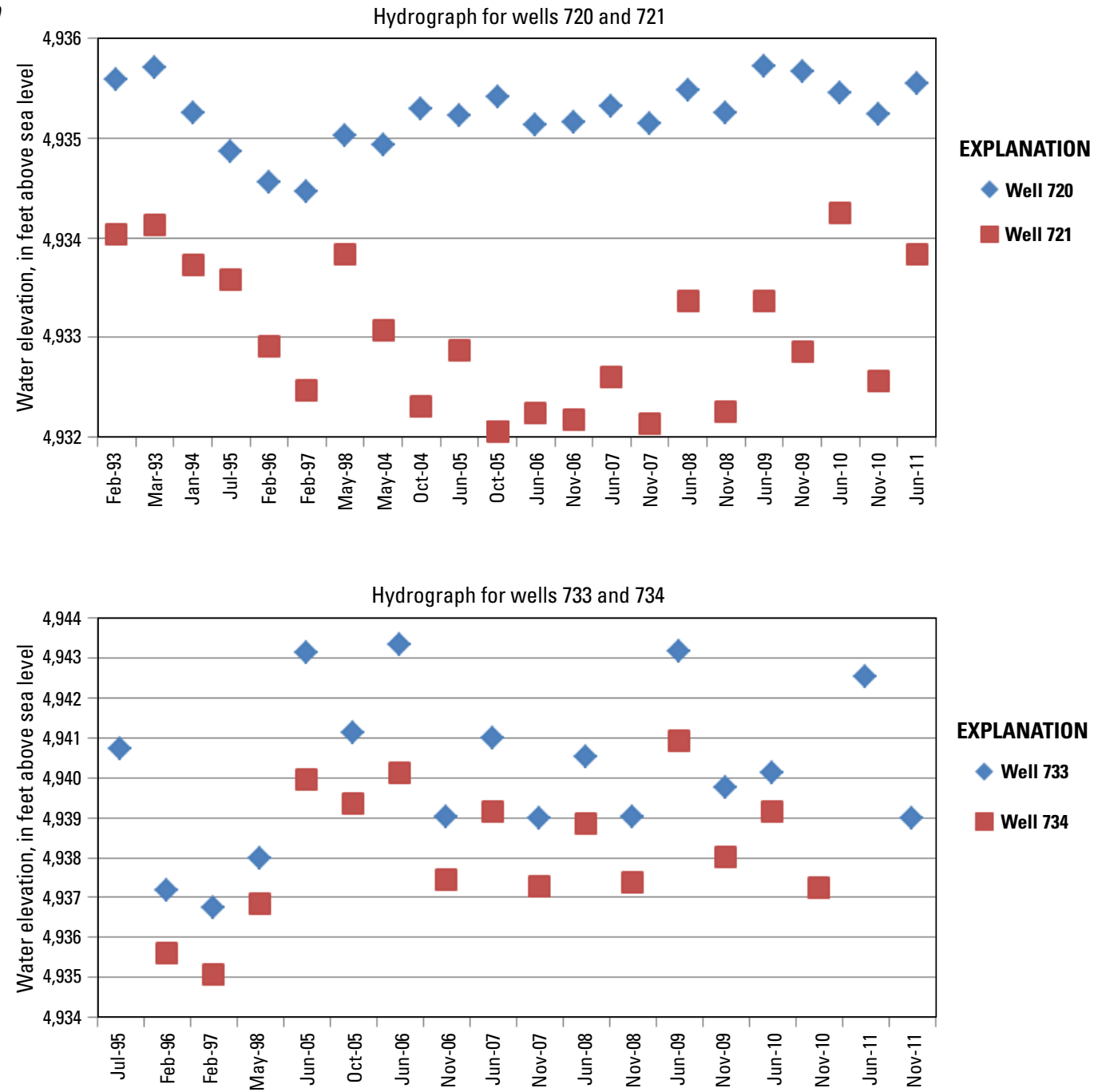

Figure 15. Hydrographs of groundwater elevation for nested U.S. Department of Energy monitoring wells for the period of record: $A$, Wells 724, 725, 726, 101, 111,110, 784, and 732; $B$, Wells 716, 717, 722R, 723, 707,705, and 709; $C$, Wells 706, 735, 718, 719, 729, and 730; and $D$, Wells 720, 721, 733, and 734.-Continued 

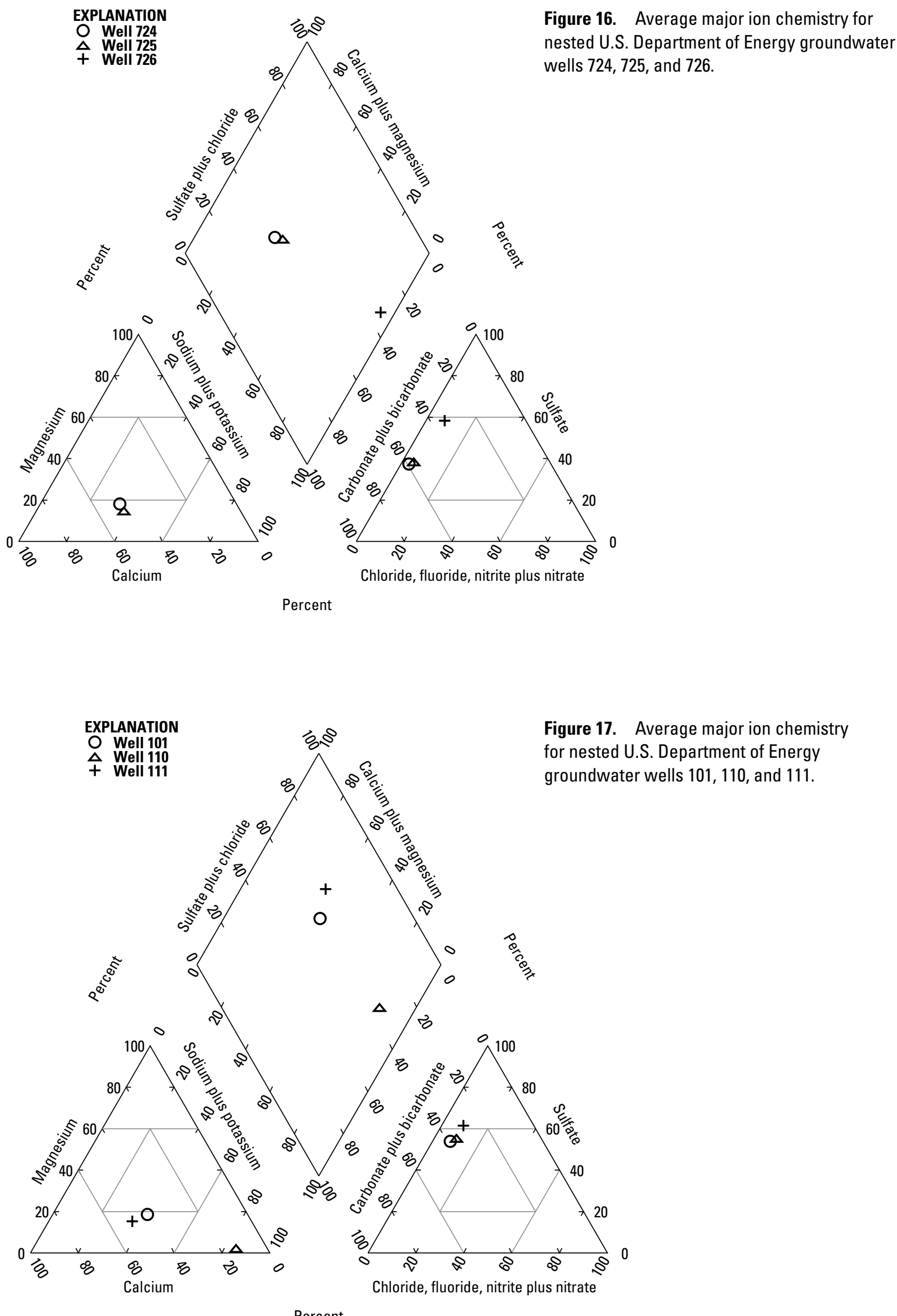

Percent 

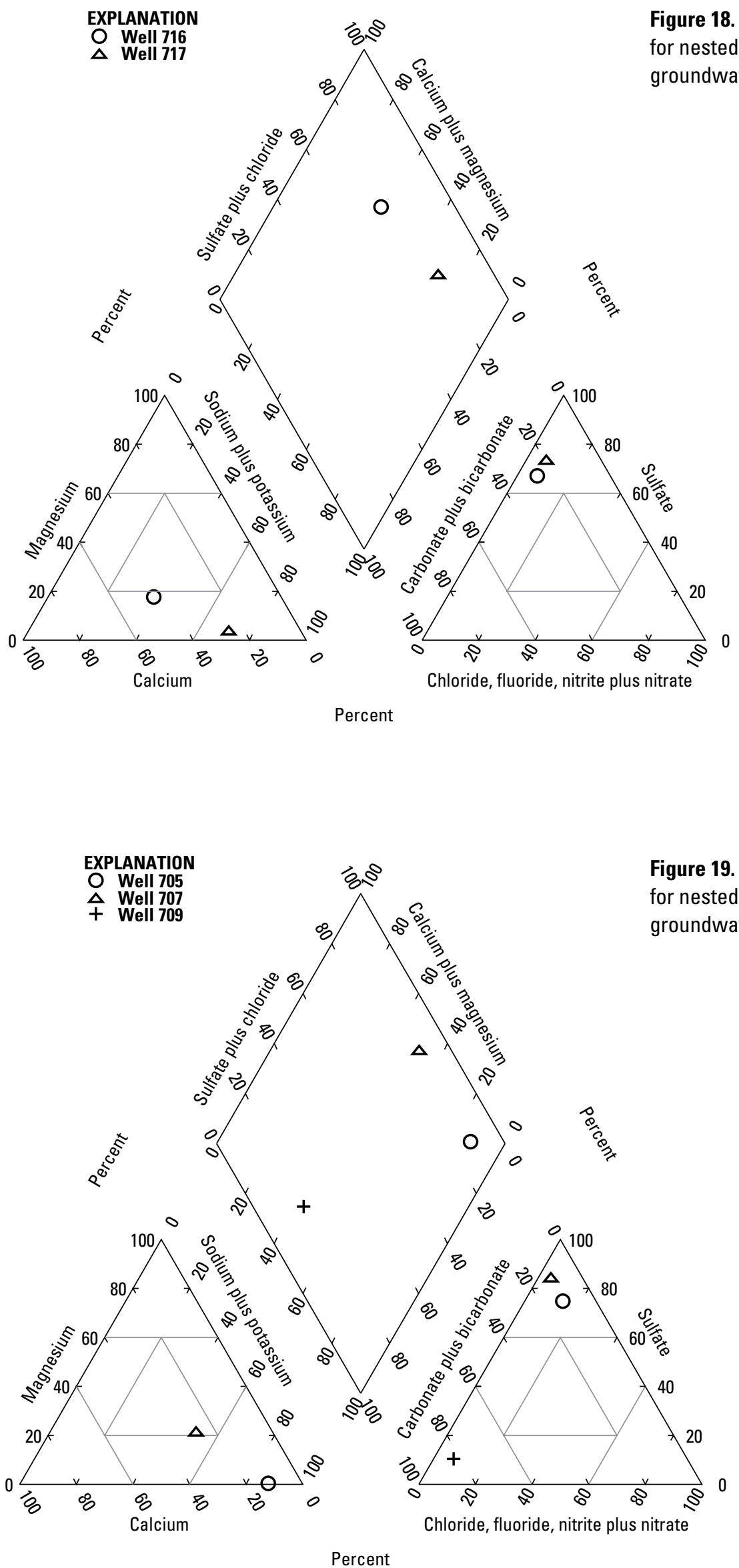

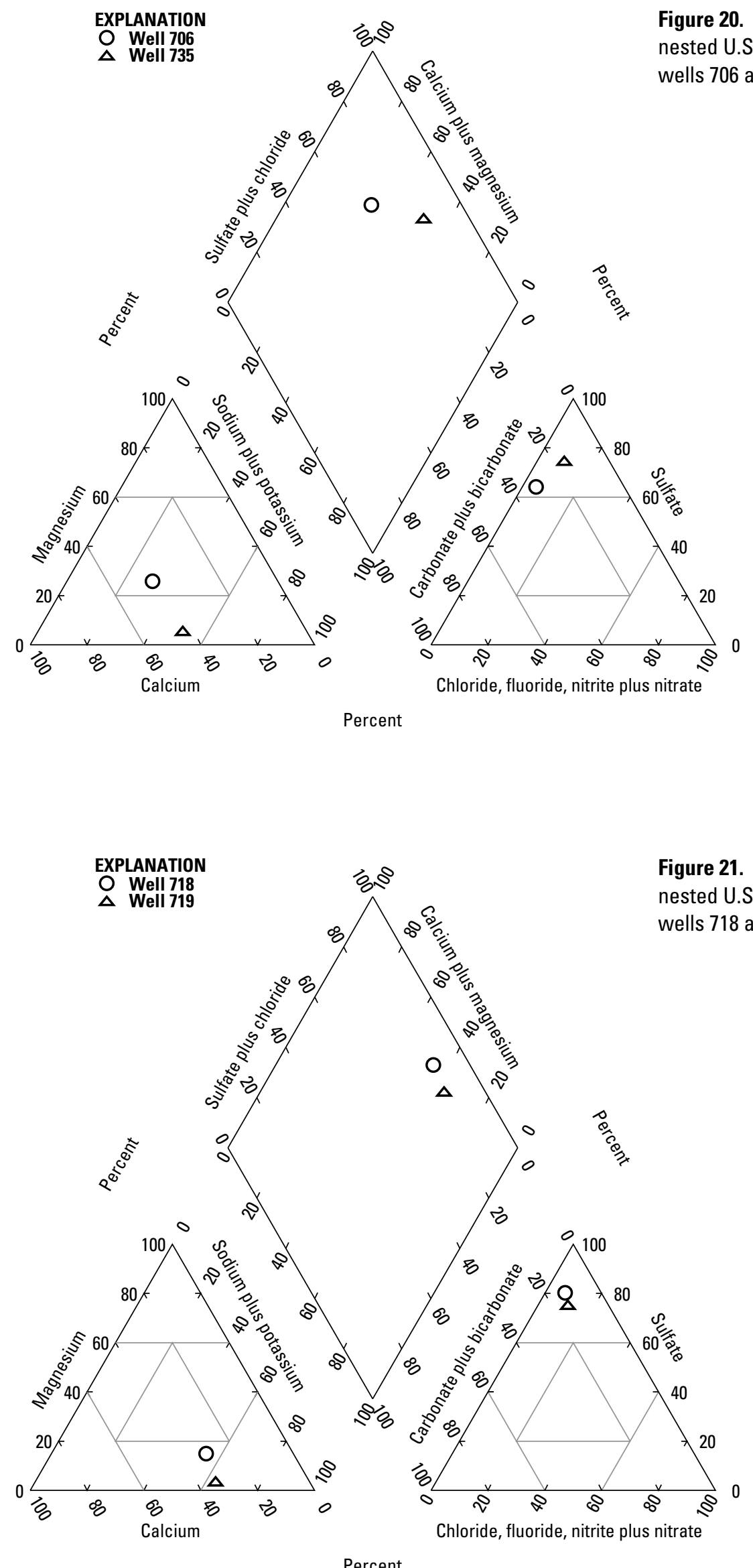

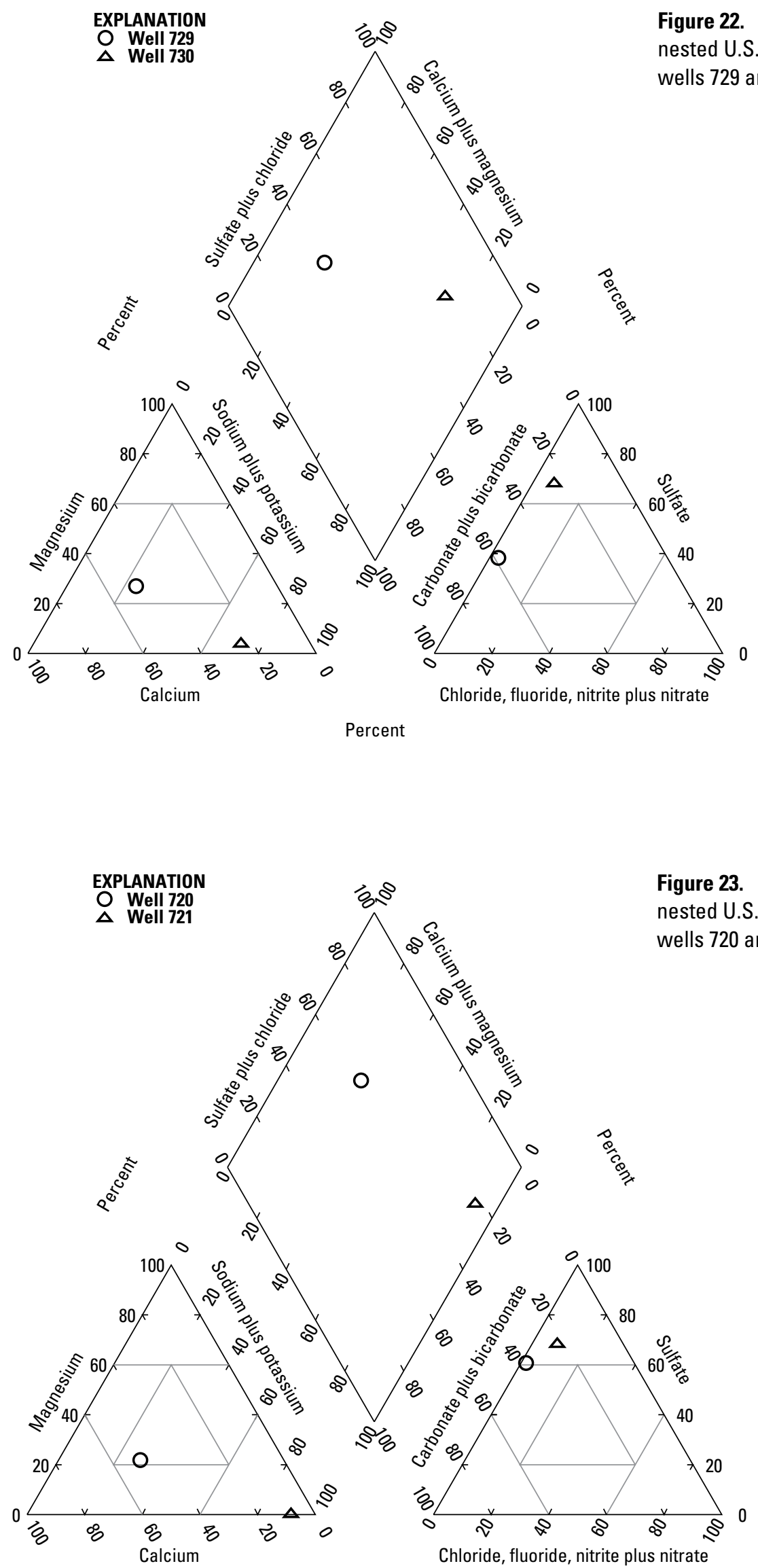

Percent 


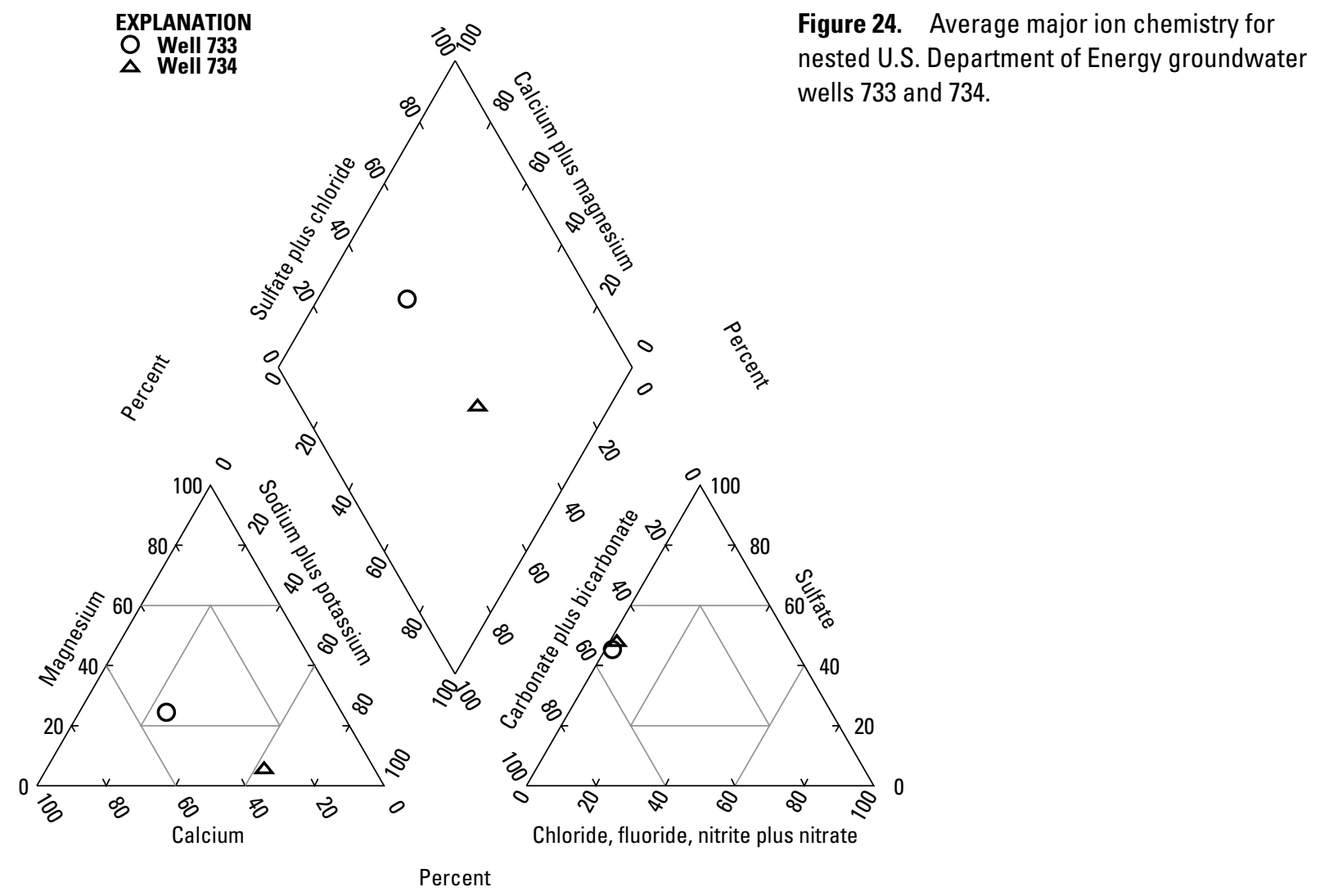

and 111 may be a result of heavy continuous pumping of well 460 in the lower confined bedrock aquifer by the sulfuricacid plant (William Dam, U.S. Department of Energy, oral commun., 2012).

The major ion composition of the groundwater indicates that mixing of groundwater in the intermediate semiconfined bedrock aquifer with groundwater in the upper unconfined alluvial aquifer could occur as the major ion composition of groundwater in both aquifers is similar (fig. 17). The well $\operatorname{logs}$, however, indicate that the similar major ion composition may not be the result of groundwater from the intermediate semiconfined bedrock aquifer mixing with groundwater in the upper unconfined alluvial aquifer. Instead it may be a result of each well sampling groundwater from individual sandstone layers within the Wind River Formation. The screen for DOE well 101 extends from 10.5 to 15.5 feet, which is within the alluvium, but the contact between the alluvium and the Wind River Formation occurs at 15.5 feet. So it is possible that water from this top sandstone layer of the Wind River Formation is introduced into DOE well 101 when it is pumped. The confining layer between the upper unconfined alluvial and the intermediate semiconfined bedrock consists of alternating siltstone and shale layers beginning at a depth of 28 feet and extending to 41 feet. DOE well 111 is screened from 39 to 54 feet in a sandstone layer. The thick layer of alternating siltstone and shale make it unlikely that groundwater from the intermediate semiconfined bedrock aquifer could mix with groundwater in the upper unconfined alluvial aquifer. The major ion composition of groundwater in the lower confined bedrock aquifer is distinct from that in the intermediate semiconfined bedrock aquifer indicating that mixing of groundwater in these two aquifers is not occurring. The confining layer between these two aquifers consists of 5 feet of a thick-bedded, hard, gray sandstone, which may be sufficient to prevent groundwater from the intermediate semiconfined bedrock aquifer migrating down into the lower confined bedrock aquifer despite a favorable hydraulic gradient.

The median concentration plots indicate that groundwater in the upper unconfined alluvial aquifer contains molybdenum, sulfate, and uranium at concentrations above background but not manganese (figs. 25-28). The intermediate semiconfined bedrock aquifer contains manganese at concentrations above background but not molybdenum, sulfate, or uranium. In the lower confined bedrock aquifer, all four of these COCs are present at background concentrations.

DOE wells 784 and 732. The hydrograph for DOE wells 784 (U) and 732 (I) shows that the water elevations in DOE well 784 are consistently greater than those in DOE well 732 by about 2 feet or more indicating a potential for groundwater to migrate down from the upper unconfined alluvial aquifer into the intermediate semiconfined bedrock aquifer (fig. 15A). There were insufficient major ion chemistry data to produce 

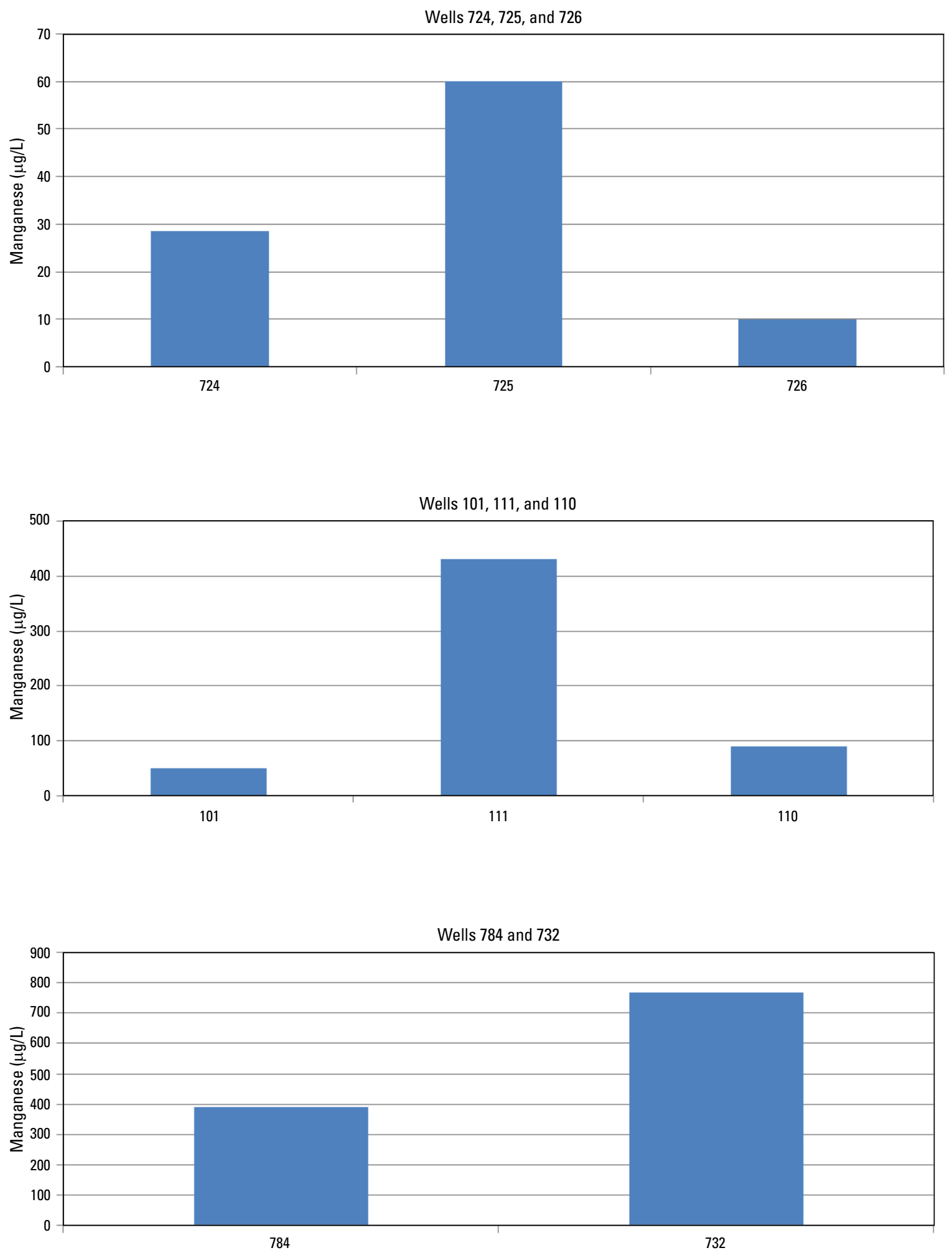

Figure 25. Median concentrations of manganese in nested U.S. Department of Energy groundwater wells. $\mu \mathrm{g} / \mathrm{L}$, micrograms per liter. 

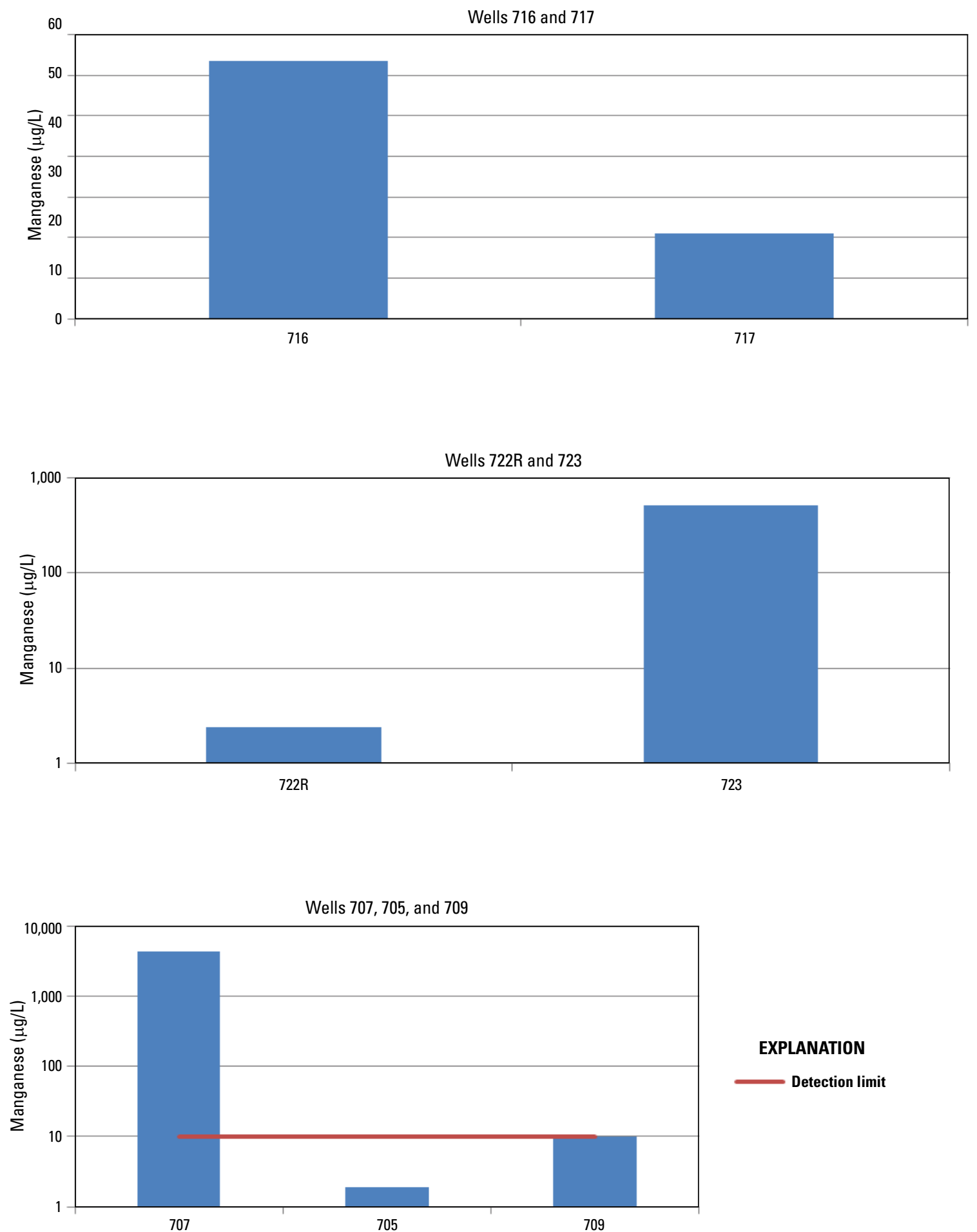

Figure 25. Median concentrations of manganese in nested U.S. Department of Energy groundwater wells. $\mu \mathrm{g} / \mathrm{L}$, micrograms per liter.-Continued 


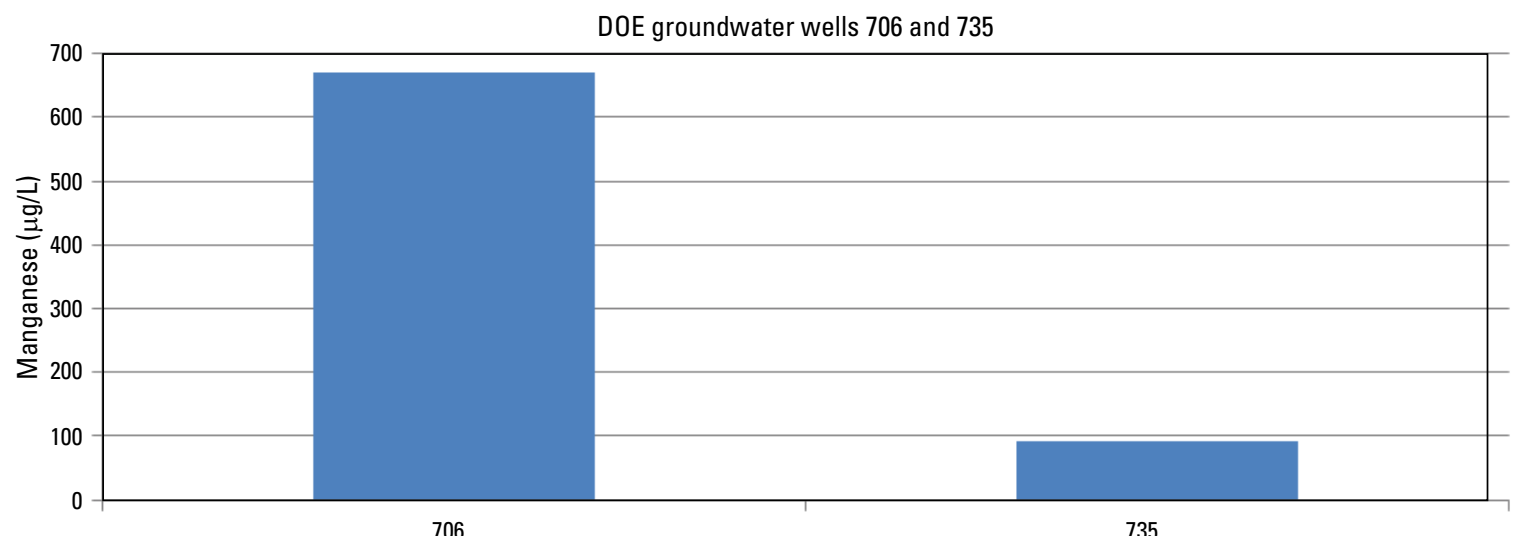

706

735
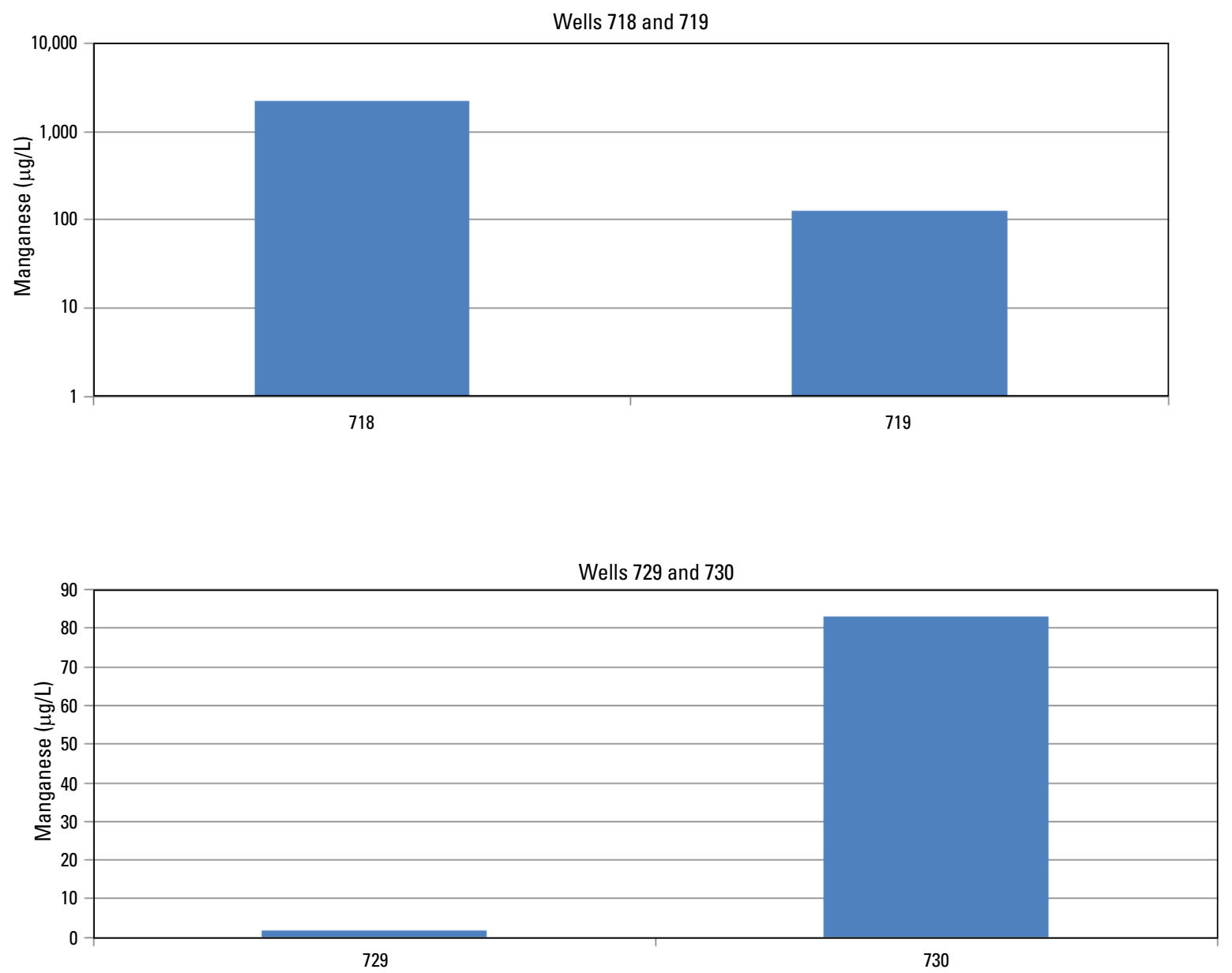

Figure 25. Median concentrations of manganese in nested U.S. Department of Energy groundwater wells. $\mu \mathrm{g} / \mathrm{L}$, micrograms per liter.-Continued 


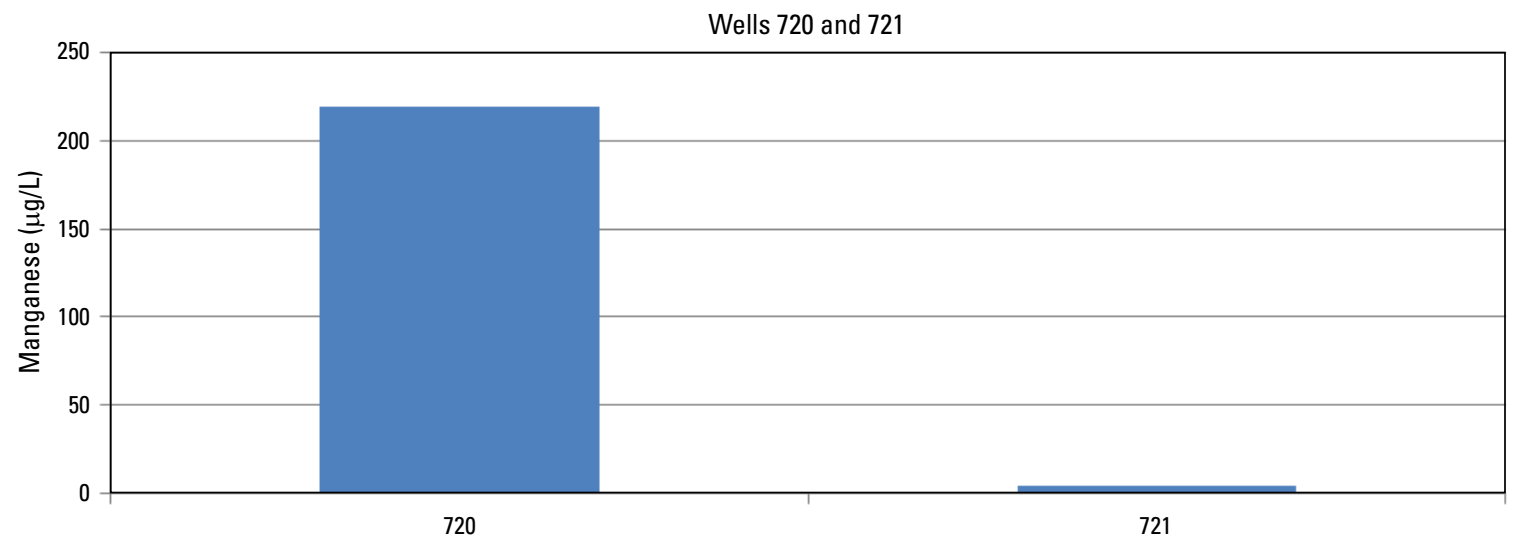

Figure 25. Median concentrations of manganese in nested U.S. Department of Energy groundwater wells. $\mu \mathrm{g} / \mathrm{L}$, micrograms per liter.-Continued

a Piper diagram, but the well logs indicate that the confining layer between the upper unconfined alluvial aquifer and the intermediate semiconfined bedrock aquifer consists of 3 feet of weathered shale. The median concentration plots indicate that groundwater in the upper unconfined alluvial aquifer and in the intermediate semiconfined bedrock aquifer contains concentrations of manganese that are near or above background and sulfate that is above background (figs. 25-28). The concentration of molybdenum was above background only in DOE well 732, so perhaps groundwater can migrate from the upper unconfined alluvial aquifer down into the intermediate semiconfined bedrock aquifer in this area. The concentration of uranium was within background conditions in both aquifers. It needs to be noted that the median concentration plots were based on only two dissolved samples collected from DOE well 732 on July 18, 1995, and May 6, 1999, and nine unfiltered (total) samples collected from DOE well 784 from 2006 through 2010.

DOE wells 716 and 717. The hydrograph for DOE wells 716 (U) and 717 (I) shows that the water elevations are about equal in both wells on each date indicating little to no potential for mixing between these aquifers (fig. 15B). The major ion composition of each aquifer is distinct also indicating that mixing is most likely not occurring (fig. 18). The confining layer between the upper unconfined alluvial aquifer and the intermediate semiconfined bedrock aquifer consists of 3 feet of highly weathered clay and shale and 6 feet of hard, dark-gray shale; therefore, mixing between the aquifers seems unlikely. The median concentration plots indicate that groundwater in the upper unconfined alluvial aquifer contains concentrations of manganese, molybdenum, sulfate, and uranium above background, but groundwater in the intermediate semiconfined bedrock aquifer contains concentrations of sulfate only above background (figs. 25-28).
DOE wells 722R and 723. The hydrograph for DOE wells 722R (U) and 723 (I) indicates a slight hydraulic gradient exists upward from the intermediate semiconfined bedrock aquifer into the upper unconfined alluvial aquifer (fig. 15B). There were insufficient major ion chemistry data to produce a Piper diagram, but the well logs indicate that the confining layer between the upper unconfined alluvial aquifer and the intermediate semiconfined bedrock aquifer consists of 3 feet of weathered shale. The median concentration plots indicate that groundwater in the upper unconfined alluvial aquifer contains concentrations of molybdenum, sulfate (unfiltered samples only), and uranium that are above background, but manganese is not (figs. 25-28). Groundwater in the intermediate semiconfined bedrock aquifer contains concentrations of manganese and sulfate that are above background. The small hydraulic gradient and the presence of only 3 feet of weathered shale indicate that it is possible for groundwater in the intermediate semiconfined bedrock aquifer to flow upward into the upper unconfined alluvial aquifer. This direction of groundwater flow, however, does not explain the presence of high concentrations of manganese and sulfate in the intermediate semiconfined bedrock aquifer.

DOE wells 707, 705, and 709. The hydrograph for DOE wells 707 (U), 705 (I), and 709 (L) (fig. 15B), except for the years 1991 and 1992, exhibits a similar pattern to that observed in DOE wells 724, 725, and 726 (fig. 15A). The greater elevation of water levels in DOE well 709 relative to the other two wells for most of the period of record indicates that groundwater from the lower confined bedrock aquifer could flow upward into the intermediate semiconfined bedrock aquifer, but groundwater from the upper two aquifers could not flow downward into the lower confined bedrock aquifer. Groundwater in the upper two aquifers could mix, however, because the groundwater-elevation data indicate that a slight 

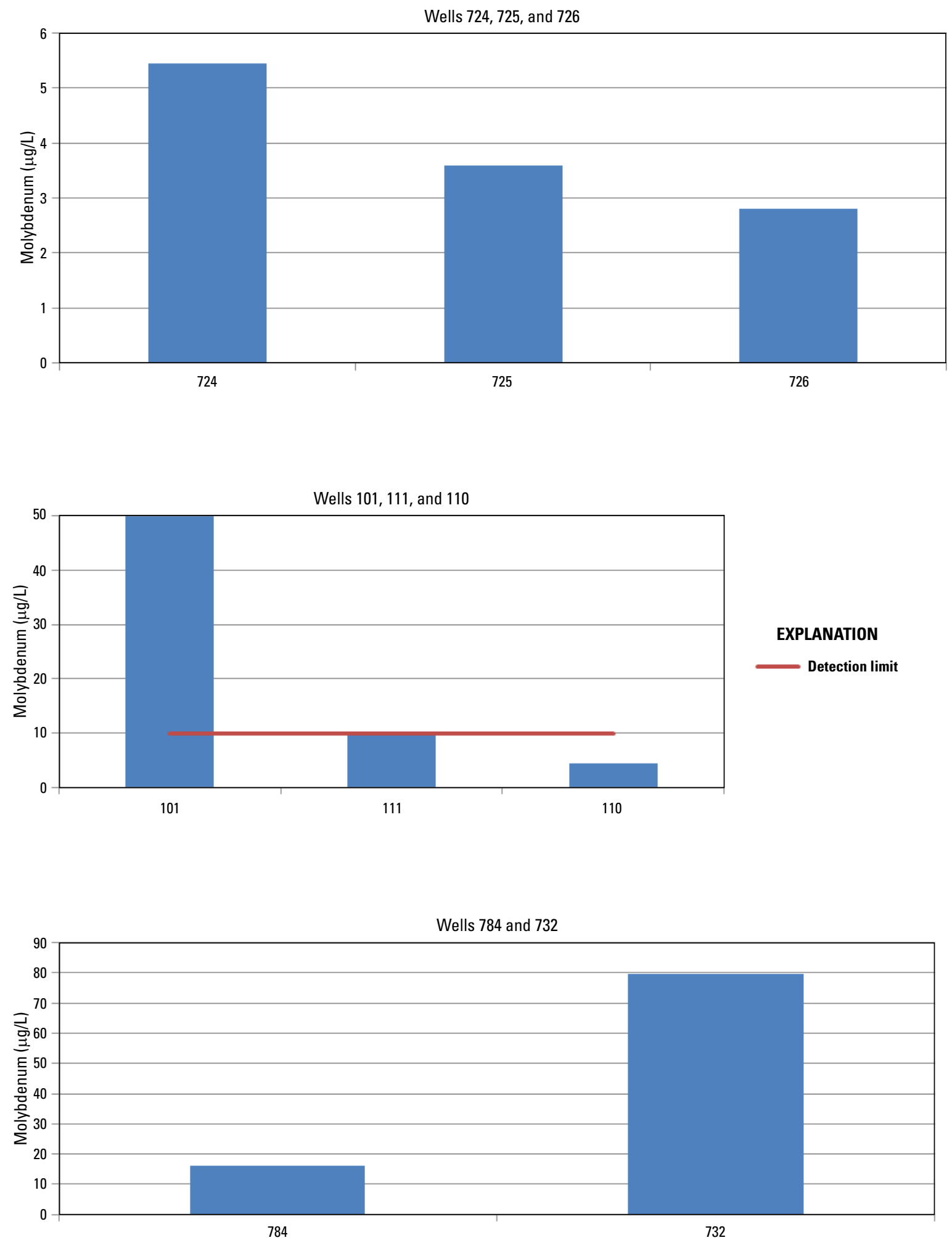

Figure 26. Median concentrations of molybdenum in nested U.S. Department of Energy groundwater wells. $\mu \mathrm{g} / \mathrm{L}$, micrograms per liter. 

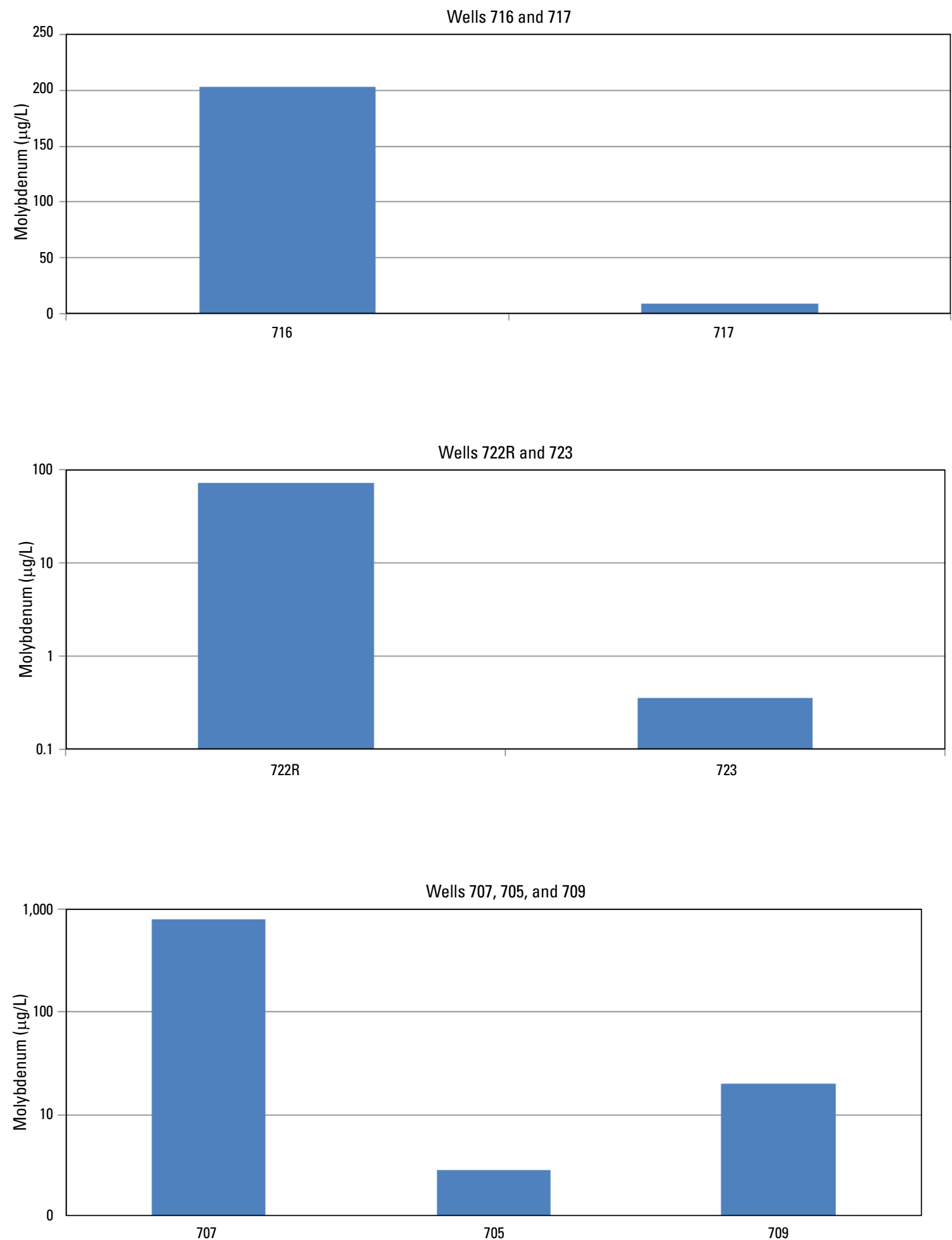

Figure 26. Median concentrations of molybdenum in nested U.S. Department of Energy groundwater wells. $\mu \mathrm{g} / \mathrm{L}$, micrograms per liter.-Continued 

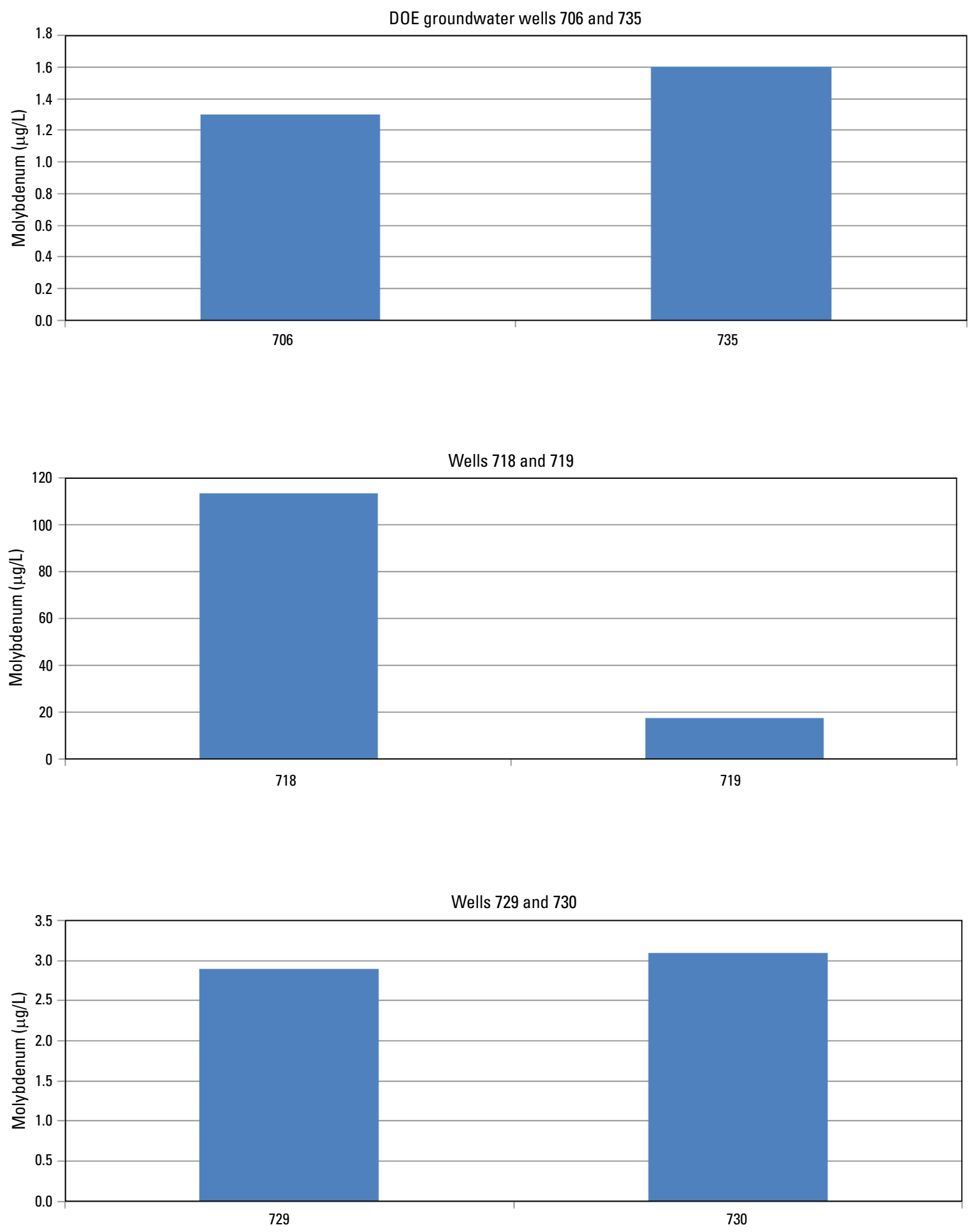

Figure 26. Median concentrations of molybdenum in nested U.S. Department of Energy groundwater wells. $\mu \mathrm{g} / \mathrm{L}$, micrograms per liter.-Continued 


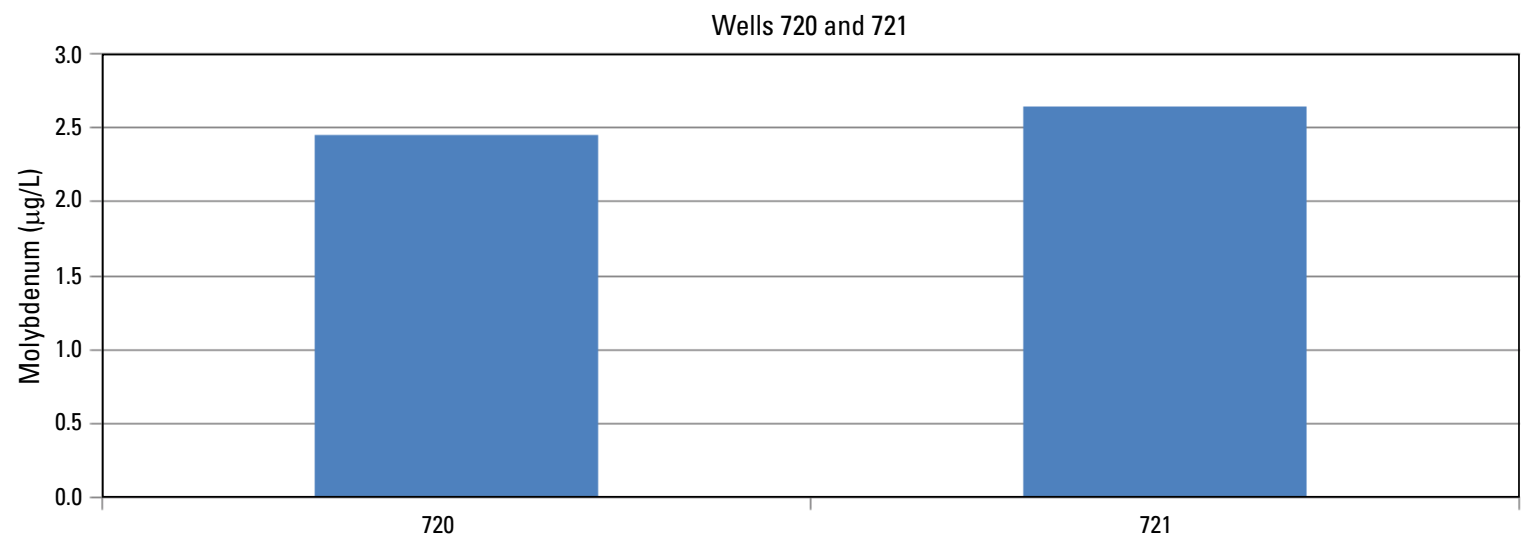

Figure 26. Median concentrations of molybdenum in nested U.S. Department of Energy groundwater wells. $\mu \mathrm{g} / \mathrm{L}$, micrograms per liter.-Continued

hydraulic gradient exists from the upper unconfined alluvial aquifer down into the intermediate semiconfined bedrock aquifer. The major ion composition of the three wells, however, indicates that mixing of groundwater among the three aquifers is most likely not occurring because the major ion composition of the groundwater in each aquifer is distinct from each other (fig. 19). The reason for the lack of mixing is the presence of a confining layer consisting of 14 feet of a hard, dark-gray claystone between the upper unconfined alluvial aquifer and the intermediate semiconfined bedrock aquifer and 33 feet of a hard, dark-gray claystone between the intermediate semiconfined bedrock and the lower confined bedrock aquifer. The median concentration data of manganese, molybdenum, sulfate, and uranium indicate that these COCs are present in concentrations above background in the upper unconfined alluvial aquifer and that only concentrations of sulfate are above background in the intermediate semiconfined bedrock aquifer (figs. 25-28).

DOE wells 706 and 735. For nested DOE wells 706 (U) and 735 (I), there is little water-elevation data for each well at the same time. The five concurrent measurements for DOE wells 706 and 735 (one in each of the years 1996, 1997, 1998, 1999, and 2000) indicate that a slight hydraulic gradient exists from the intermediate semiconfined bedrock aquifer upward into the upper unconfined alluvial aquifer (fig. 15C). The major ion chemistry data indicate that mixing between the unconfined alluvial aquifer and the intermediate semiconfined aquifer is probably not occurring to a large degree (fig. 20). Although it should be noted that the point on the Piper diagram for DOE well 735 is based on one sample, whereas the point for DOE well 706 is an average of 20 samples. The confining layer between the upper unconfined alluvial aquifer and the intermediate semiconfined bedrock aquifer at this location consists of 3 feet of clay, so this may be sufficient to inhibit mixing of groundwater in the two aquifers.
The median concentration data indicate that the concentration of molybdenum and uranium is at background levels for both wells (figs. 25-28). The concentration of manganese is well above background in DOE well 706 but is at background in DOE well 735. The concentration of sulfate is below background in DOE well 706 but above background in DOE well 735.

DOE wells 718 and 719. The hydrograph for DOE wells 718 (U) and 719 (I) shows that groundwater elevations in DOE well 719 are consistently slightly greater than in DOE well 718 indicating a potential for groundwater in the intermediate semiconfined aquifer to migrate upward into the upper unconfined alluvial aquifer (fig. 15C). The major ion composition of groundwater in each aquifer is similar indicating that mixing of groundwater between the two aquifers may be occurring (fig. 21). The confining layer between the two aquifers at this location consists of 3 feet of a highly weathered silty clay and shale. So it is possible that groundwater from the intermediate semiconfined aquifer does migrate upward into the upper unconfined alluvial aquifer. The median concentration of each of the COCs is above background in DOE well 718 but is at background in DOE well 719, except for sulfate, which is above background (figs. 25-28).

DOE wells 729 and 730 . The hydrograph for DOE wells 729 (U) and 730 (I) shows that the water elevations in DOE well 729 are slightly greater than those in DOE well 730 on almost all dates indicating a potential for groundwater to migrate down from the upper unconfined alluvial aquifer into the intermediate semiconfined bedrock aquifer (fig. 15C). The major ion chemistry data indicate that mixing between the unconfined alluvial aquifer and the intermediate semiconfined aquifer is probably not occurring, because the major ion composition of groundwater in each aquifer is substantially different (fig. 22). The confining layer 

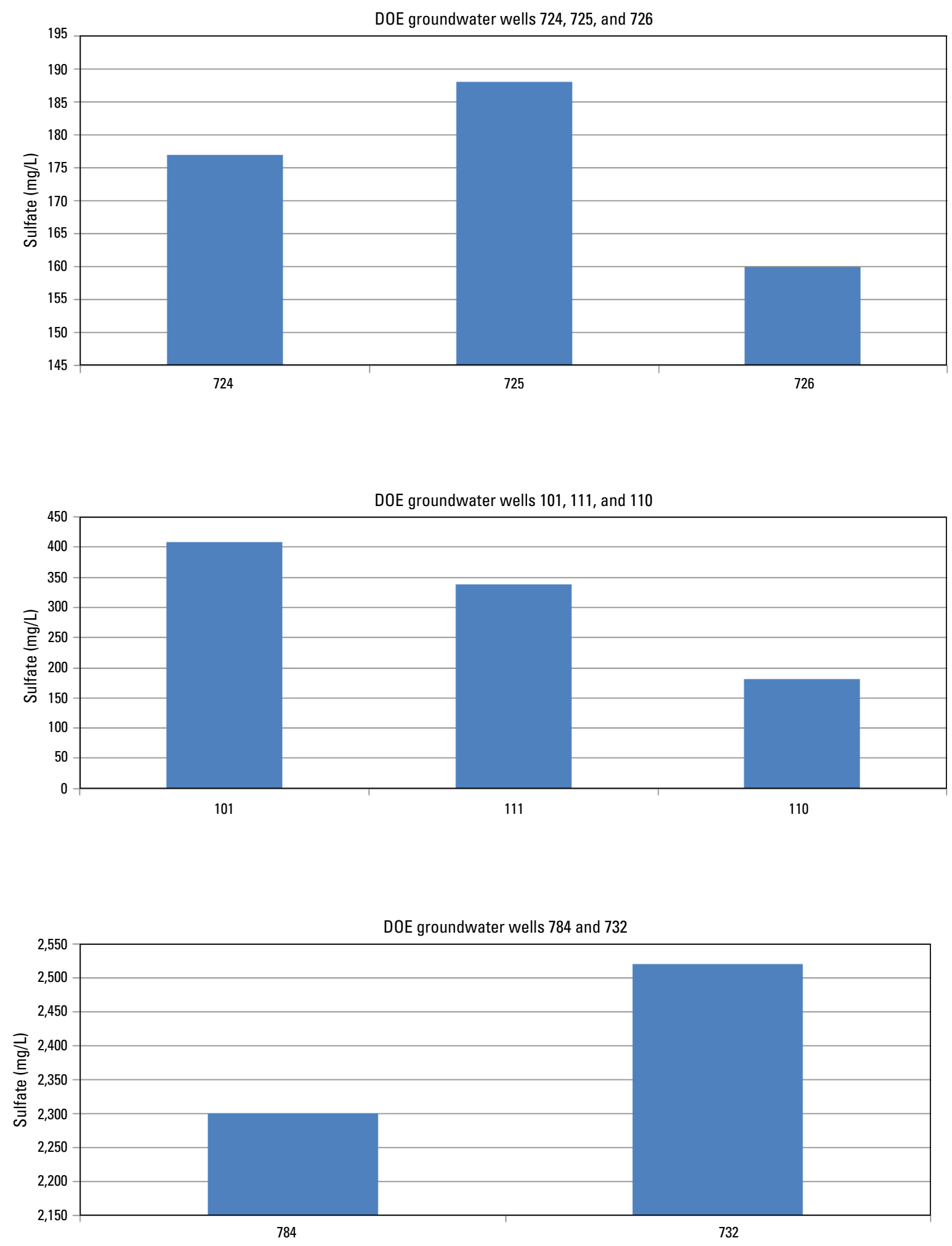

Figure 27. Median concentrations of sulfate in nested U.S. Department of Energy groundwater wells. mg/L, milligrams per liter. 

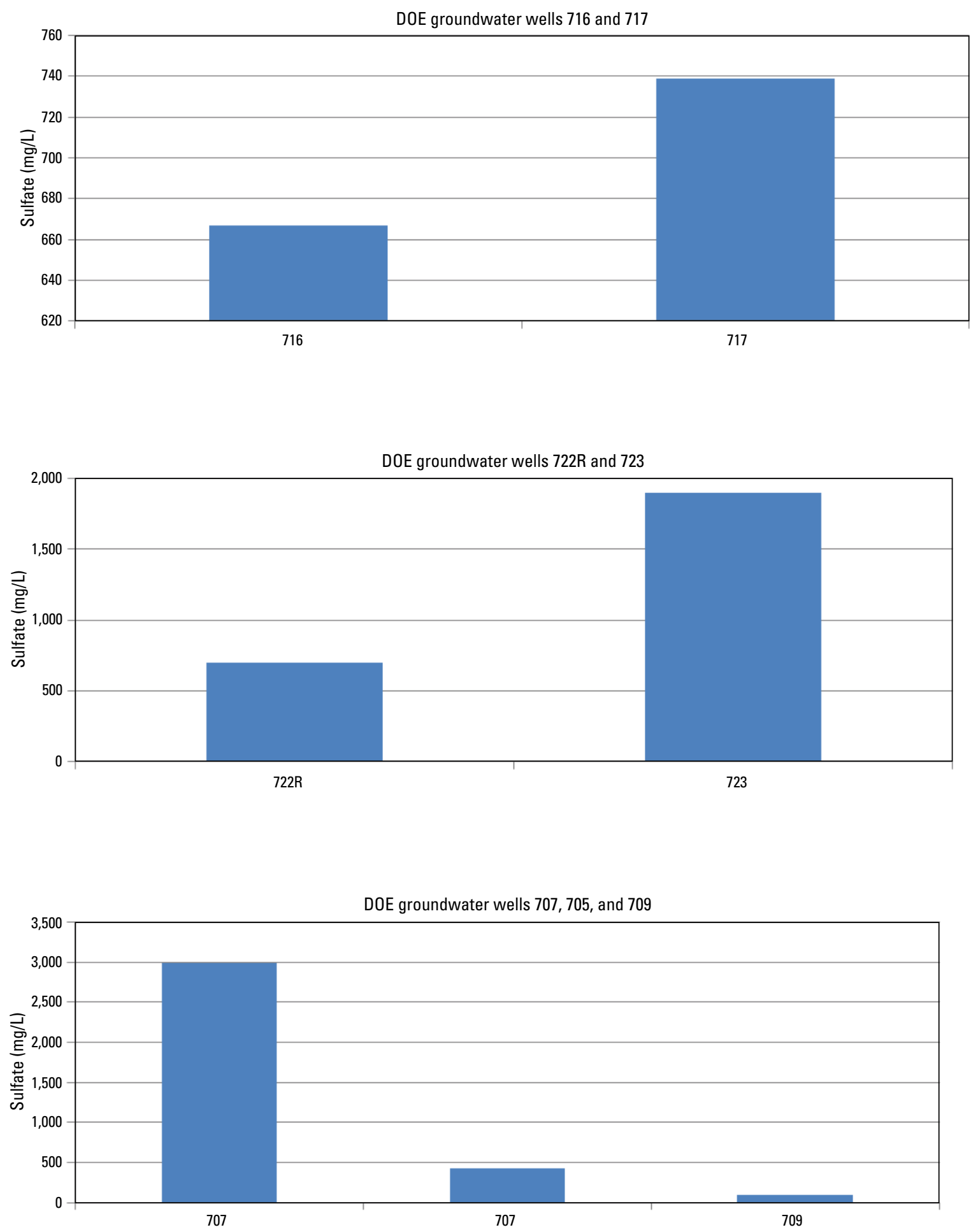

Figure 27. Median concentrations of sulfate in nested U.S. Department of Energy groundwater wells. mg/L, milligrams per liter.-Continued 

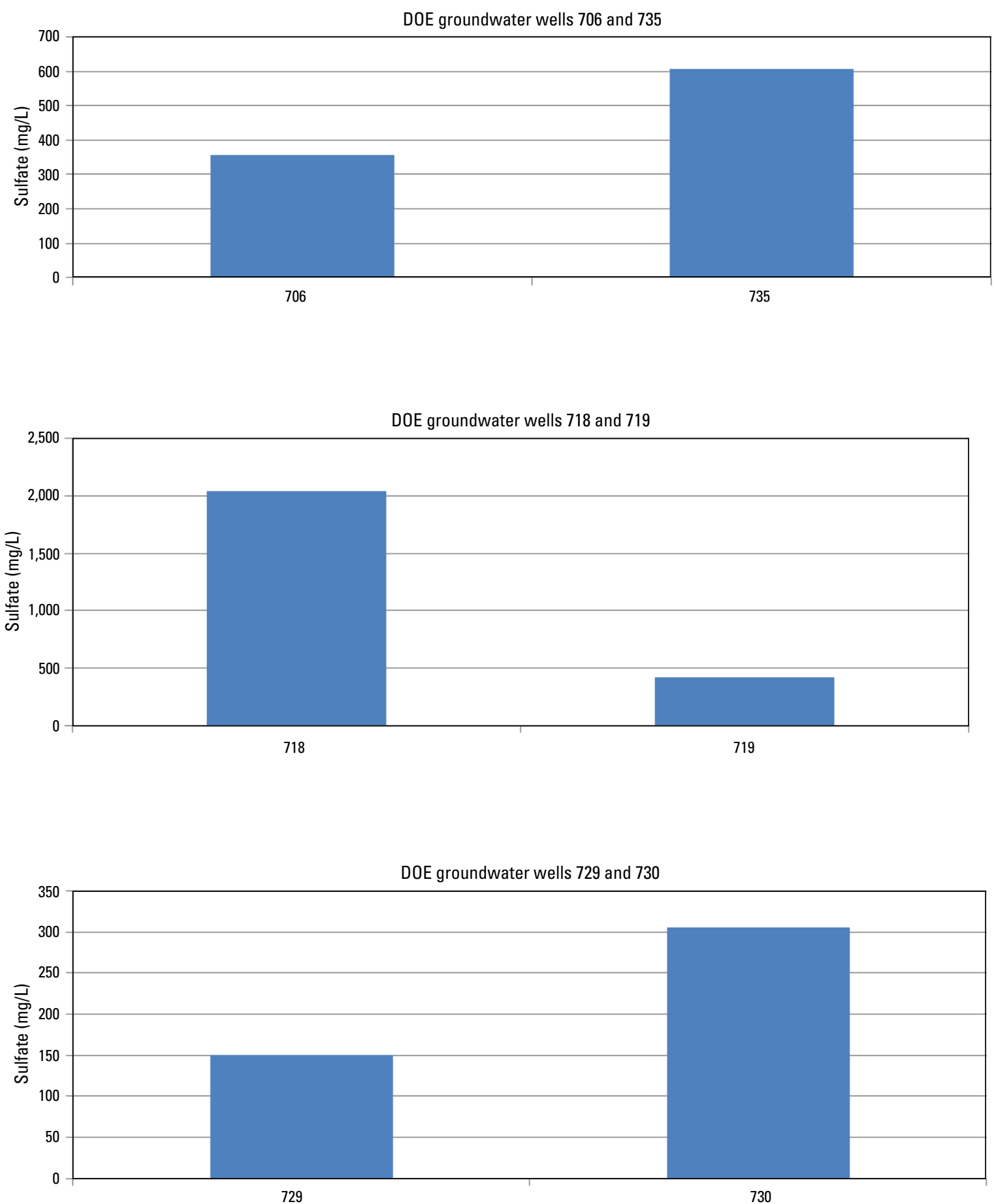

Figure 27. Median concentrations of sulfate in nested U.S. Department of Energy groundwater wells. $\mathrm{mg} / \mathrm{L}$, milligrams per liter-Continued 


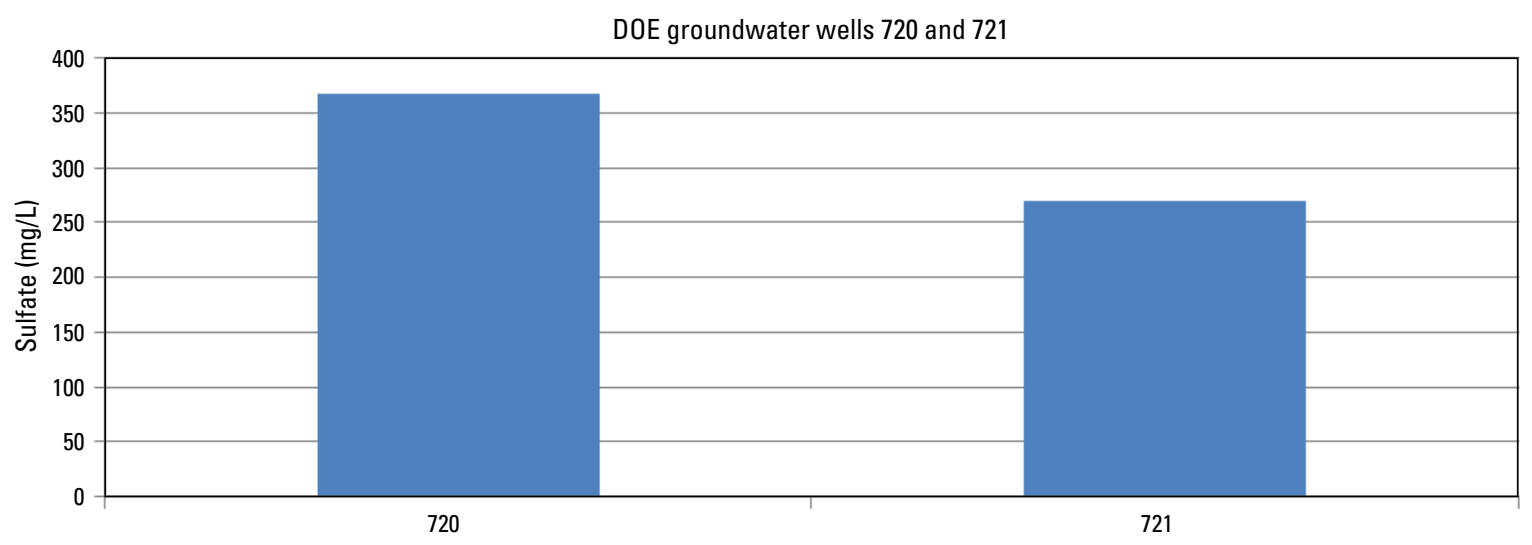

Figure 27. Median concentrations of sulfate in nested U.S. Department of Energy groundwater wells. $\mathrm{mg} / \mathrm{L}$, milligrams per liter.-Continued

between the two aquifers at this location consists of 4 feet of clay and shale, which could inhibit groundwater from the upper unconfined alluvial aquifer migrating down into the intermediate semiconfined bedrock aquifer despite a favorable hydraulic gradient. The median concentration of manganese, molybdenum, and uranium are similar in each well and are within background (figs. 25-28). The median concentration of sulfate in DOE well 730 is greater than in DOE well 729 but is within background for both wells.

DOE wells 720 and 721. The hydrograph for DOE wells 720 (U) and 721 (I) shows that the water elevations in DOE well 720 are consistently greater than those in DOE well 721 by about 2 feet or more indicating a potential for groundwater to migrate down from the upper unconfined alluvial aquifer into the intermediate semiconfined bedrock aquifer (fig. 15D). The major ion chemistry data indicate that mixing between the unconfined alluvial aquifer and the intermediate semiconfined aquifer is probably not occurring, however, because the major ion composition of groundwater in each aquifer is substantially different (fig. 23). As was the situation at the location of DOE wells 729 and 730, the presence of a confining layer consisting of 3 feet of clay and shale may be sufficient to prevent the mixing of groundwater despite a favorable hydraulic gradient. The median concentrations of manganese, sulfate, and uranium are higher in DOE well 720 but are within background, and the concentration of molybdenum is similar in the two aquifers and within background (figs. 25-28).

DOE wells 733 and 734. The hydrograph for DOE wells 733 (U) and 734 (I) shows that the water elevations in DOE well 733 are consistently greater than those in DOE well 734 by about 1 foot or more indicating a potential for groundwater to migrate down from the upper unconfined alluvial aquifer into the intermediate semiconfined bedrock aquifer (fig. 15D). The major ion chemistry data indicate that mixing between the unconfined alluvial aquifer and the intermediate semiconfined aquifer is probably not occurring, however, because the major ion composition of groundwater in each aquifer is substantially different (fig. 24). The chemistry data available for each well, however, are very limited and no well logs were available. Only two samples were collected from DOE well 733 (collected on July 18, 1995, and May 6, 1999) and one sample from DOE well 734 (collected on February 17, 1996). The concentrations of manganese, molybdenum, sulfate, and uranium were within background for each of the three samples.

In summary, it appears that groundwater in the lower confined bedrock aquifer is not vulnerable to contamination from the upper unconfined alluvial aquifer. The hydrostatic pressure in the lower confined bedrock aquifer in the area of nested DOE wells 724 (U), 725 (I), and 726 (L) and nested DOE wells $707(\mathrm{U}), 705(\mathrm{I})$, and $709(\mathrm{~L})$ is great enough to prevent water from the upper two aquifers from migrating downward into it. In the area of nested DOE wells $101(\mathrm{U})$, 111 (I), and 110 (L) there is a hydraulic gradient from the upper two aquifers down into the lower confined bedrock aquifer. The greater hydrostatic pressure in the intermediate semiconfined bedrock aquifer relative to the upper unconfined alluvial aquifer, however, would prevent the migration of contaminants from the upper unconfined alluvial aquifer downward. The chemistry data support the interpretation of the water-elevation data. The major ion composition of the groundwater in the lower confined bedrock aquifer is distinct from that of the upper two aquifers in each set of nested wells. The median concentration of manganese, molybdenum, sulfate, and uranium in DOE wells 110 and 709 is within the range measured in the upgradient background well (DOE well $726)$ in the lower confined bedrock aquifer. Also in the area of DOE wells 722R (U) and 723 (I), 718 (U) and 719 (I), and possibly $706(\mathrm{U})$ and $735(\mathrm{I})$, the greater hydrostatic pressure in the intermediate semiconfined bedrock aquifer relative to that in the upper unconfined alluvial aquifer would prevent groundwater from the upper unconfined alluvial aquifer from migrating down into the lower confined bedrock aquifer. 

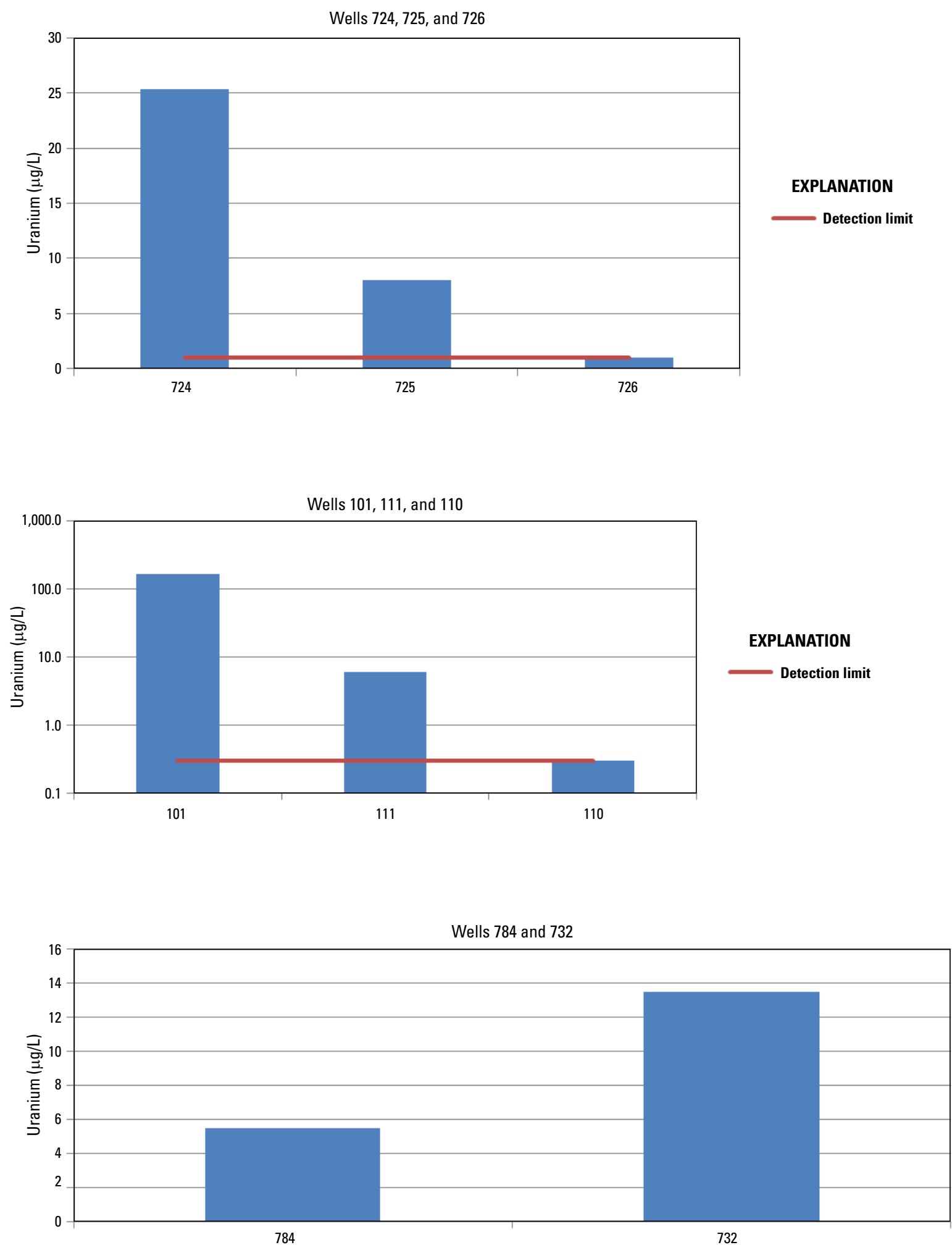

Figure 28. Median concentrations of uranium in nested U.S. Department of Energy groundwater wells. $\mu \mathrm{g} / \mathrm{L}$, micrograms per liter. 

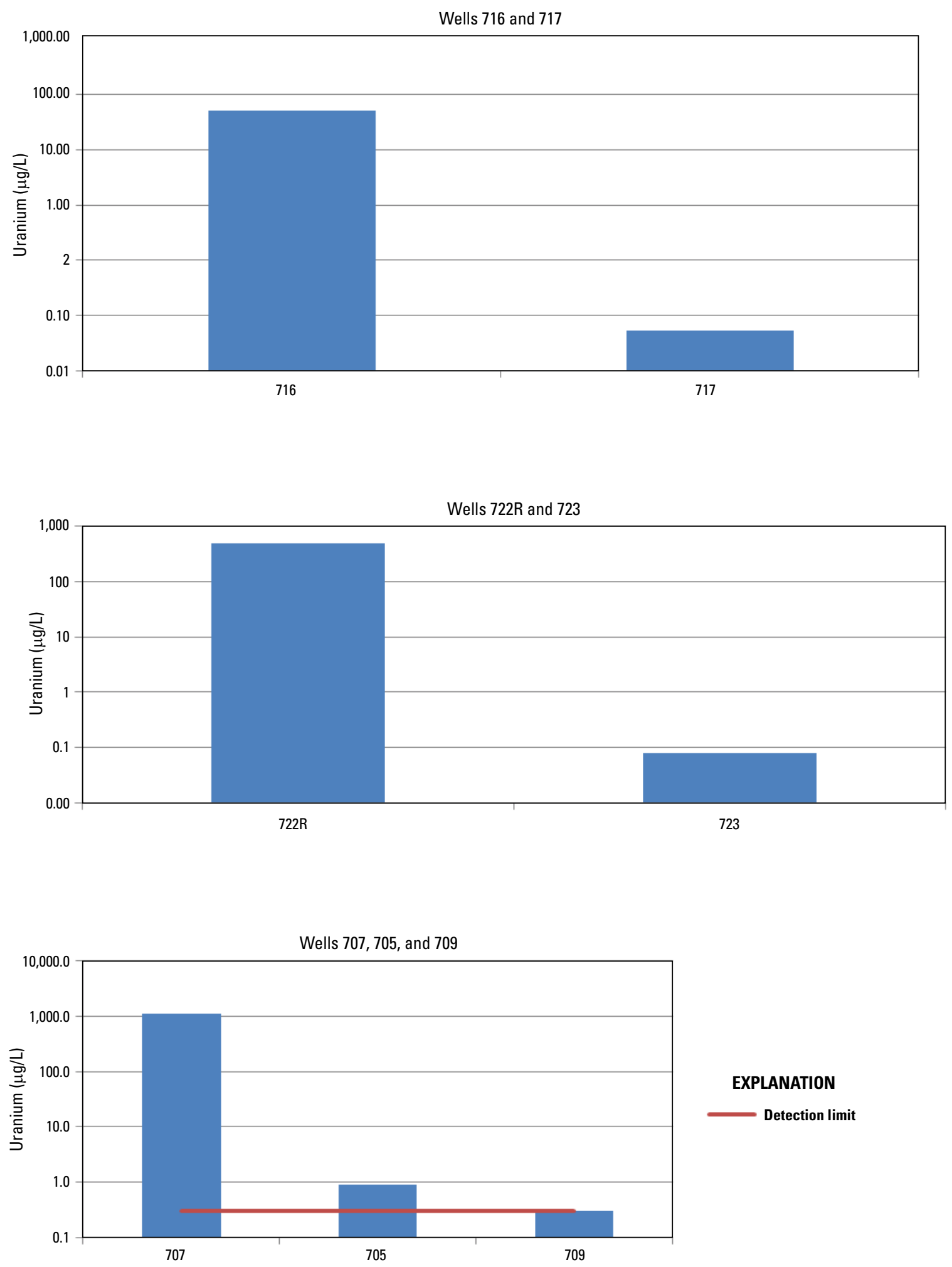

Figure 28. Median concentrations of uranium in nested U.S. Department of Energy groundwater wells. $\mu \mathrm{g} / \mathrm{L}$, micrograms per liter.-Continued 

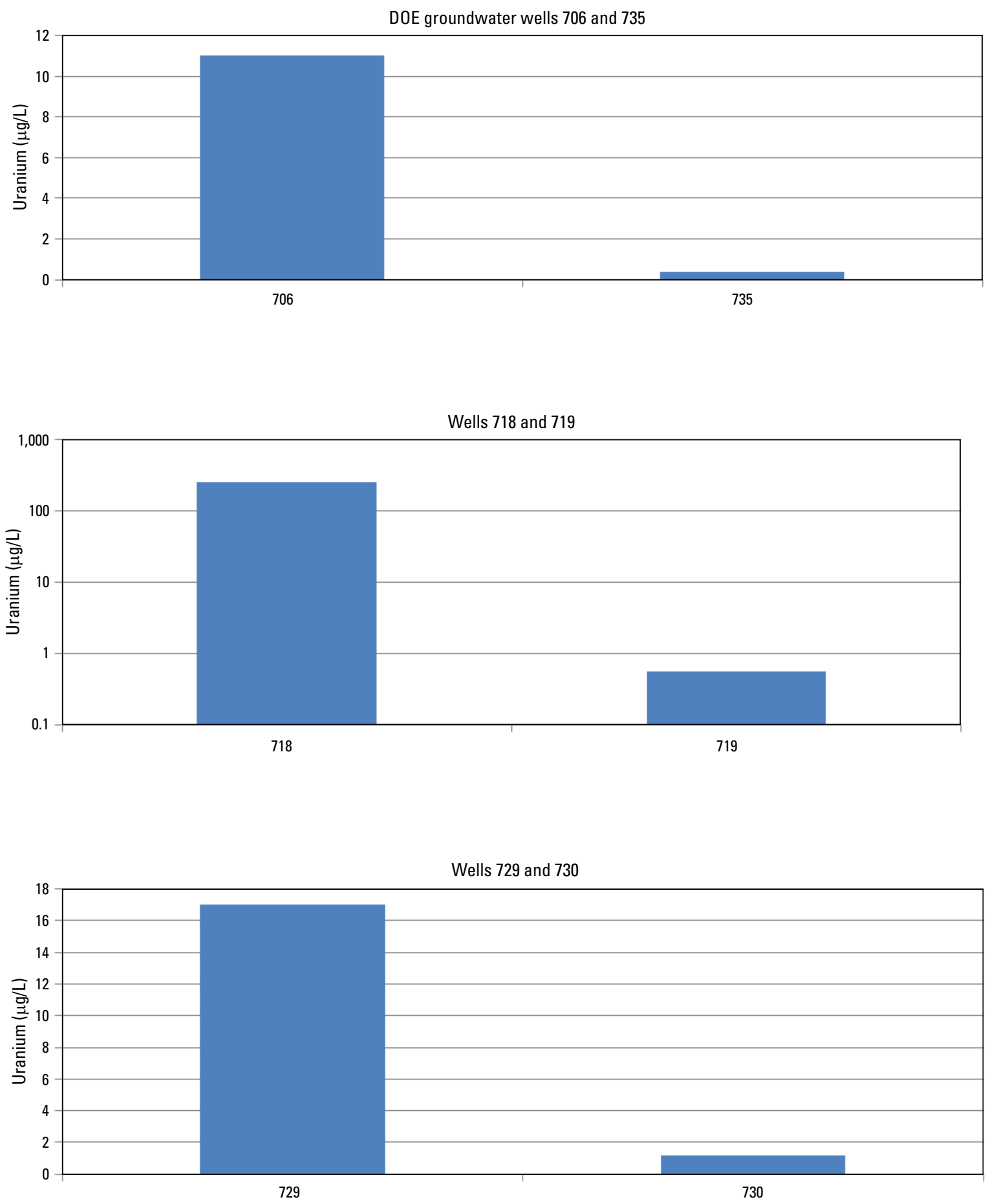

Figure 28. Median concentrations of uranium in nested U.S. Department of Energy groundwater wells. $\mu \mathrm{g} / \mathrm{L}$, micrograms per liter.-Continued 


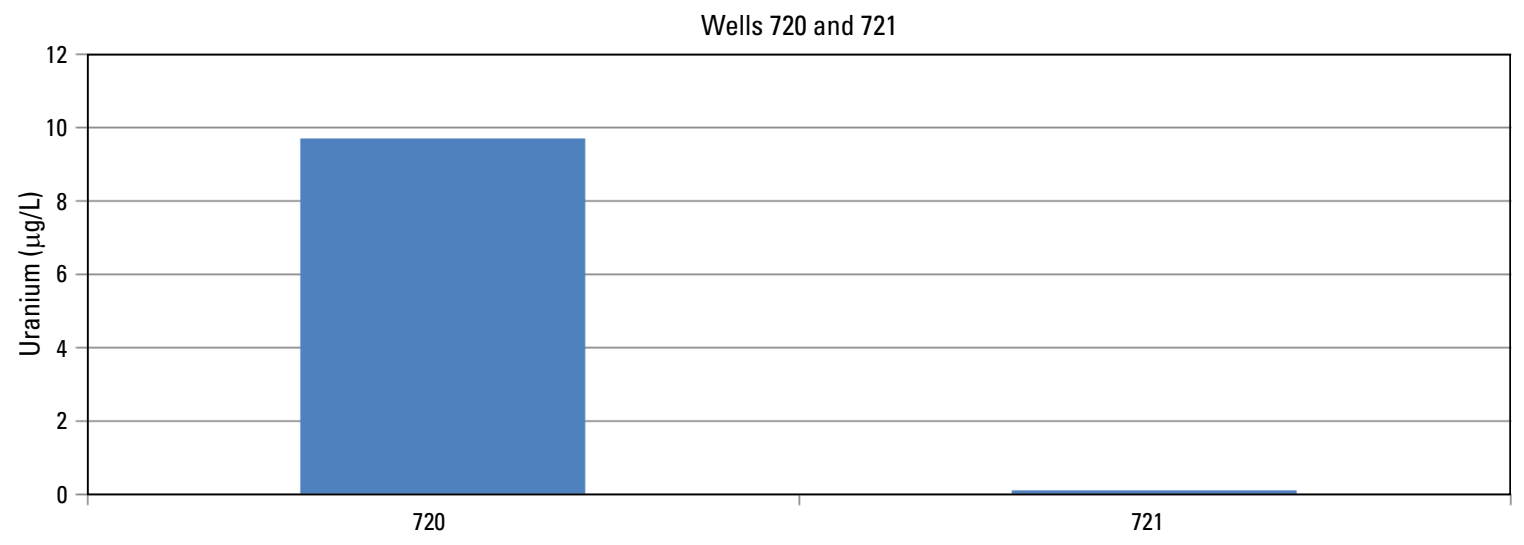

Figure 28. Median concentrations of uranium in nested U.S. Department of Energy groundwater wells. $\mu \mathrm{g} / \mathrm{L}$, micrograms per liter.-Continued

Based on differences in groundwater elevations, there does appear to be a potential for the exchange of groundwater between the upper unconfined alluvial aquifer and the intermediate semiconfined aquifer in some areas of the UMTRA site. There is a hydraulic gradient greater than 1 foot from the intermediate semiconfined bedrock aquifer upward into the upper unconfined alluvial aquifer in the area of nested DOE wells $101(\mathrm{U}), 111$ (I), and 110 (L) and less than 1 foot in DOE wells 722R (U) and 723 (I), 718 (U) and 719 (I), and possibly in the area of 706 (U) and 735 (I). There is a hydraulic gradient of 1 foot or more downward from the upper unconfined alluvial aquifer into the intermediate semiconfined bedrock aquifer in the area of nested DOE wells 784 (U) and 732 (I), 720 (U) and 721 (I), and 733 (U) and 734 (I), and a hydraulic gradient of less than 1 foot downward from the upper unconfined alluvial aquifer into the intermediate semiconfined aquifer in the area of nested DOE wells 707 (U), 705 (I), and 709 (L) and 729 (U) and 730 (I). In the area of nested DOE wells $724(\mathrm{U}), 725(\mathrm{I})$, and $726(\mathrm{~L})$ and nested DOE wells 716 (U) and 717 (I), the water elevations in the upper unconfined alluvial aquifer and the intermediate semiconfined aquifer are about equal indicating little to no potential for groundwater mixing between aquifers.

Despite the presence of favorable hydraulic gradients in several locations, the chemical and geological data (well logs) indicate that mixing of groundwater between the upper unconfined alluvial aquifer and the intermediate semiconfined bedrock aquifer occurs only in a few areas. Movement of groundwater from the upper unconfined alluvial aquifer to the intermediate semiconfined bedrock aquifer could only occur in the area of DOE wells 784 (U) and 732 (I). Movement of groundwater from the intermediate semiconfined bedrock aquifer to the upper unconfined alluvial aquifer could occur in the area of DOE wells $718(\mathrm{U})$ and $719(\mathrm{I}), 722 \mathrm{R}(\mathrm{U})$ and 723 (I), and possibly 101 (U) and 111 (I).

Above-background concentrations of manganese and sulfate occur in the intermediate semiconfined bedrock aquifer in the area of DOE wells 723 and 732; molybdenum in well 732 is also above background and sulfate only in DOE wells $705,717,719$, and 735 . The mechanism by which COCs may have migrated down into intermediate semiconfined aquifer, however, is not clear. It is also not clear why molybdenum (except in DOE well 732) and uranium were never measured at concentrations above background in the intermediate semiconfined aquifer.

There are several hypotheses to explain the presence of COCs in the intermediate semiconfined bedrock aquifer. The DOE states that when the mill was in operation, drainage from the tailings pile would have mounded groundwater in the unconfined alluvial aquifer resulting in a downward vertical hydraulic gradient (U.S. Department of Energy, 1998). So perhaps when the tailings pile was present at the mill it created a hydraulic gradient from the upper unconfined alluvial aquifer down into the intermediate semiconfined aquifer, which allowed contamination to migrate down into this aquifer. As a result, the presence of these COCs throughout the intermediate semiconfined aquifer is a result of lateral migration downgradient from the former mill site. Or perhaps in the area around DOE well 784 the plume would have migrated or still is migrating down into the intermediate semiconfined bedrock aquifer. The available water-elevation and geologic data indicate that the area at DOE wells 784 and 732 is the only location within the upper unconfined alluvial aquifer where the potential for groundwater to migrate down into the intermediate semiconfined bedrock aquifer exists. Another possibility is that the hydraulic gradient in the area of DOE wells $722 \mathrm{R}$ and 723 and 718 and 719 varies at other 
times of the year as to allow for a downward migration of groundwater from the upper unconfined alluvial aquifer into the intermediate semiconfined bedrock aquifer.

An understanding of the mechanism by which COCs have entered the intermediate semiconfined aquifer is needed to better evaluate their fate in this aquifer and in the upper unconfined alluvial aquifer. If the COCs entered into the intermediate semiconfined bedrock aquifer only as a result of the presence of the tailings pile, then no further addition of COCs into this aquifer has occurred since the tailings piles were removed in 1989. The amount of time it will take for the COCs to reach background concentrations is then dependent upon the rate at which the hydrologic and geochemical processes in this aquifer can diminish the original amount of COCs introduced into the aquifer. If, however, COCs have been migrating into the intermediate semiconfined aquifer from the upper unconfined alluvial aquifer since 1989, then this represents a loss of COCs from the upper unconfined alluvial aquifer and a gain to the intermediate semiconfined bedrock aquifer. A continuous introduction of COC's from the upper unconfined alluvial aquifer into the intermediate semiconfined bedrock aquifer would most likely result in a different amount of time needed to reach background concentrations in each aquifer than if the introduction of COCs into the intermediate semiconfined bedrock aquifer ceased after 1989.

None of the hypotheses described above can explain why uranium and molybdenum exist only at background concentrations in the intermediate semiconfined bedrock aquifer if COCs are migrating into it. The reason why these two COCs are not detected in measurable amounts may be a result of the controls on solubility as a result of changing redox conditions (mostly for uranium) and (or) dilution. An understanding of the processes controlling the concentrations of uranium and molybdenum is needed to understand the fate of these COCs in this aquifer. For example, if these COCs are precipitating out of solution when reducing conditions occur, then they can be dissolved when oxygenated conditions occur. A cyclical pattern of precipitation and dissolution would be a major influence of the fate of these COCs; however, if dilution is occurring, the concentrations will always remain at background levels.

Because the solubility of uranium is redox dependent, perhaps it is precipitating out of solution if reducing conditions occur in the intermediate semiconfined bedrock aquifer. An indication that uranium could possibly precipitate out of solution in the intermediate semiconfined bedrock aquifer is shown by comparing the saturation indices for coffinite and uraninite in DOE well 717 on April 1, 1993, and February 9, 1997 (table 2). The saturation index calculated on April 1, 1993, for coffinite was -21.37 and for uraninite was -20.93 , but on February 9, 1997, when the groundwater approached reducing conditions, the saturation index for coffinite was -3.99 and for uraninite it was -3.56 . Although still well undersaturated, these calculations indicate that as the concentration of dissolved oxygen decreases, the groundwater approaches saturation with respect to these two minerals. Thus, it is possible that uranium could precipitate out of solution in the intermediate semiconfined aquifer under reducing conditions. This same pattern of groundwater approaching equilibrium with respect to these two minerals with a change in redox conditions was observed also in DOE well 726 (lower semiconfined bedrock aquifer) (table 2). Thus, if the groundwater in the intermediate semiconfined aquifer experiences reducing conditions to a greater degree and more frequently than in the upper unconfined alluvial aquifer, then it is plausible that precipitation of some uranium minerals could possibly occur and contribute to the low concentrations of uranium in this aquifer.

The solubility of molybdenum may be controlled more by the concentration of calcium than dissolved oxygen (Hem, 1985). Saturation indices for several solid phase molybdenum species $\left(\mathrm{CaMoO}_{4}, \mathrm{MgMoO}_{4}, \mathrm{Na}_{2} \mathrm{MoO}_{4}\right.$, and $\mathrm{K}_{2} \mathrm{MoO}_{4}$ ) for groundwater samples collected from DOE wells 101 (February 8, 1997), 707 (February 9, 1997), 716 (April 1, 1993), and 717 (February 9, 1997) are presented in table 2. The groundwater in each sample is well oxygenated except for DOE well 717 on February 9, 1997, and undersaturated with respect to each of these molybdenum compounds except for $\mathrm{CaMoO}_{4}$ in DOE well 707 on February 9, 1997. The groundwater in this sample was in equilibrium with $\mathrm{CaMoO}_{4}$, and the major difference between these samples was the much higher concentration of calcium in DOE well 707 relative to the other samples. The concentration of calcium was $456 \mathrm{mg} / \mathrm{L}$ in DOE well 707, $178 \mathrm{mg} / \mathrm{L}$ in DOE well 101, $194 \mathrm{mg} / \mathrm{L}$ in DOE well 716 on February 9, 1997, and 199 mg/L in DOE well 716 on April 1, 1993, and 107 mg/L in DOE well 717. Only in the sample with a relatively high concentration of calcium did the groundwater achieve equilibrium with a solid phase molybdenum compound. Another control on molybdenum mobility is the species of molybdenum in solution. Molybdenum is in solution exclusively as $\mathrm{MoO}_{4}{ }^{2-}$ in each sample. Molybdenum, therefore, is mobile in groundwater in each aquifer because there is little tendency for molybdenum to precipitate out of solution and $\mathrm{MoO}_{4}{ }^{2-}$ does not sorb readily to aquifer sediments. However, it has been reported that molybdenum could sorb to amorphous ferric oxyhydroxide (Hem, 1985).

A potential problem with the hypothesis that the occurrence of reducing conditions is the mechanism by which low concentrations of uranium occur is that the concentration of sulfate can also decrease under reducing conditions by conversion to sulfide (Drever, 1988). What may be happening is that if reducing conditions occur in the intermediate semiconfined bedrock aquifer, then the precipitation of uranium may be occurring before redox conditions reach the level needed for sulfate reduction. In other words, under reducing conditions, uranium precipitation may occur before sulfate reduction does, perhaps concurrently with nitrate, iron, or manganese reduction. So perhaps if reducing conditions occur, it is sufficient to induce uranium precipitation but not sulfate reduction. 
Another possibility is that dilution has a relatively greater effect on the concentration of molybdenum and uranium than the concentration of manganese and sulfate. If manganese and sulfate derived from the mill were present at concentrations up to several orders of magnitude greater than molybdenum and uranium, then it is possible that molybdenum and uranium could be diluted to background concentrations. For example, suppose sulfate was introduced into the upper unconfined alluvial aquifer at a concentration of $50,000 \mathrm{mg} / \mathrm{L}$ and uranium was introduced into the aquifer at a concentration of $1,000 \mu \mathrm{g} / \mathrm{L}$. If this plume of contaminated groundwater was diluted by a factor of 100 by upgradient groundwater, then the concentration of sulfate would be $500 \mathrm{mg} / \mathrm{L}$, which is above background, and the concentration of uranium would be $10 \mu \mathrm{g} / \mathrm{L}$, which is representative of background concentrations.

The hypotheses to explain the source of manganese and sulfate and the mechanism by which manganese and sulfate may have migrated down into the intermediate semiconfined alluvial aquifer but not molybdenum and uranium could be evaluated with the collection of the following data:

1. The direction and magnitude of the hydraulic gradient between the upper unconfined alluvial aquifer and the intermediate semiconfined bedrock aquifer is variable in space, but the variability in time is not well defined. The water-elevation data presented in figure 15 are limited, consisting of only a couple of measurements per year. Thus, in the area of DOE wells 722R and 723 and 718 and 719 , where the chemistry and geologic data indicate that an exchange of groundwater between the upper two aquifers occurs, a reversal in the hydraulic gradient, if it occurs at other times of the year, could allow COCs to migrate down into the intermediate semiconfined bedrock aquifer. More frequent water-elevation measurements, perhaps weekly or monthly for several years to account for a range of hydrologic conditions such as periods of drought or flood in nested wells $722 \mathrm{R}$ and 723 and 718 and 719 as well as 784 and 732,101 and 111, 706 and 735 , and 716 and 717 could be made to determine if a reversal in the hydraulic gradient occurs.

2. The more frequent water-elevation measurements indicated for DOE wells listed in number 1 above could be supplemented with quarterly to monthly water-quality sampling. The water-quality samples should be analyzed for field properties $(\mathrm{pH}$, specific conductance, dissolved oxygen, and water temperature), dissolved major ions $\left(\mathrm{Ca}^{2+}, \mathrm{Mg}^{2+}, \mathrm{Na}^{+}, \mathrm{K}^{+}, \mathrm{HCO}_{3}^{-}\right.$, and $\left.\mathrm{Cl}^{-}\right)$, silica, and total and dissolved manganese, molybdenum, sulfate, and uranium. In addition, if the concentration of dissolved oxygen is zero, then an additional measurement of redox potential such as oxidation reduction potential or a redox couple such as nitrate/ammonia or $\mathrm{Fe}^{+2} / \mathrm{Fe}^{+3}$ should be made.

3. One-time sampling of all of the wells discussed in this section for the analysis of $\delta^{18} \mathrm{O}_{\text {sulfate }}$ and $\delta^{34} \mathrm{~S}_{\text {sulfate }}$ and
${ }^{234} \mathrm{U} /{ }^{238} \mathrm{U}$ could be done. Because sulfuric acid was used in ore processing in the mill, the isotopic compositions of both $\delta^{18} \mathrm{O}_{\text {sulfate }}$ and $\delta^{34} \mathrm{~S}_{\text {sulfate }}$ can provide a unique isotopic fingerprint of groundwater contamination derived from mill sources (Naftz and others, 2011). The ${ }^{234} \mathrm{U} /{ }^{238} \mathrm{U}$ ratio of uranium derived from ore is distinct from uranium derived from the weathering of soil and rock that has been exposed to oxidizing conditions (Naftz and others, 2011). Analyzing the value of these isotopic pairs among the wells would help determine the source of uranium and sulfate in groundwater and may also help determine the importance of dilution and precipitation in controlling the concentration of sulfate and uranium in each aquifer. Collection of major ion and trace-element data concurrently can support the interpretation of the isotopic data in determining the importance of precipitation and dilution. For example, if only dilution is occurring, then the constituents of interest ( $\mathrm{U}$ and $\mathrm{SO}_{4}{ }^{2-}$ ) should vary together along a flow path, such as from DOE well 101 to 717 to $722 \mathrm{R}$ to 707 . If precipitation is occurring, then the elements involved in the precipitating phase would vary while others remain constant.

\section{Groundwater-Surface-Water Interaction between the Three Aquifers and the Little Wind River}

The groundwater-surface-water interaction between the three aquifers and the Little Wind River was evaluated by comparing water-elevation data measured by the DOE in several wells adjacent to the Little Wind River with discharge measured in the Little Wind River at Riverton (USGS ID 06235500) by the USGS (http://waterdata.usgs.gov/wy/nwis/ $s w)$. The DOE wells discussed in this section were chosen because of their location adjacent to the Little Wind River and because they had pressure transducers installed in them that allowed for frequent monitoring of groundwater elevation. The groundwater levels were compared to discharge in the Little Wind River and not staff gage height because the USGS gaging station on the Little Wind River is located near the confluence of the Wind River, which is east of the wells discussed in this section and is not shown on figure 2. It was thought that because the USGS gaging station is located at such a distance from these wells comparing groundwater elevation with river stage would not be appropriate.

Figure 29 shows water elevations measured in DOE wells 707,702 , and 709, which are in the upper unconfined alluvial aquifer, the intermediate semiconfined bedrock aquifer, and the lower confined bedrock aquifer, respectively, on the north side of the river; DOE wells 809 and 735, which are in the upper unconfined alluvial aquifer and the intermediate semiconfined bedrock aquifer on the south side of the river; and discharge in the Little Wind River. Also shown on figure $29 A$ is DOE well 789 , which is screened in the upper unconfined alluvial aquifer on the north bank of 

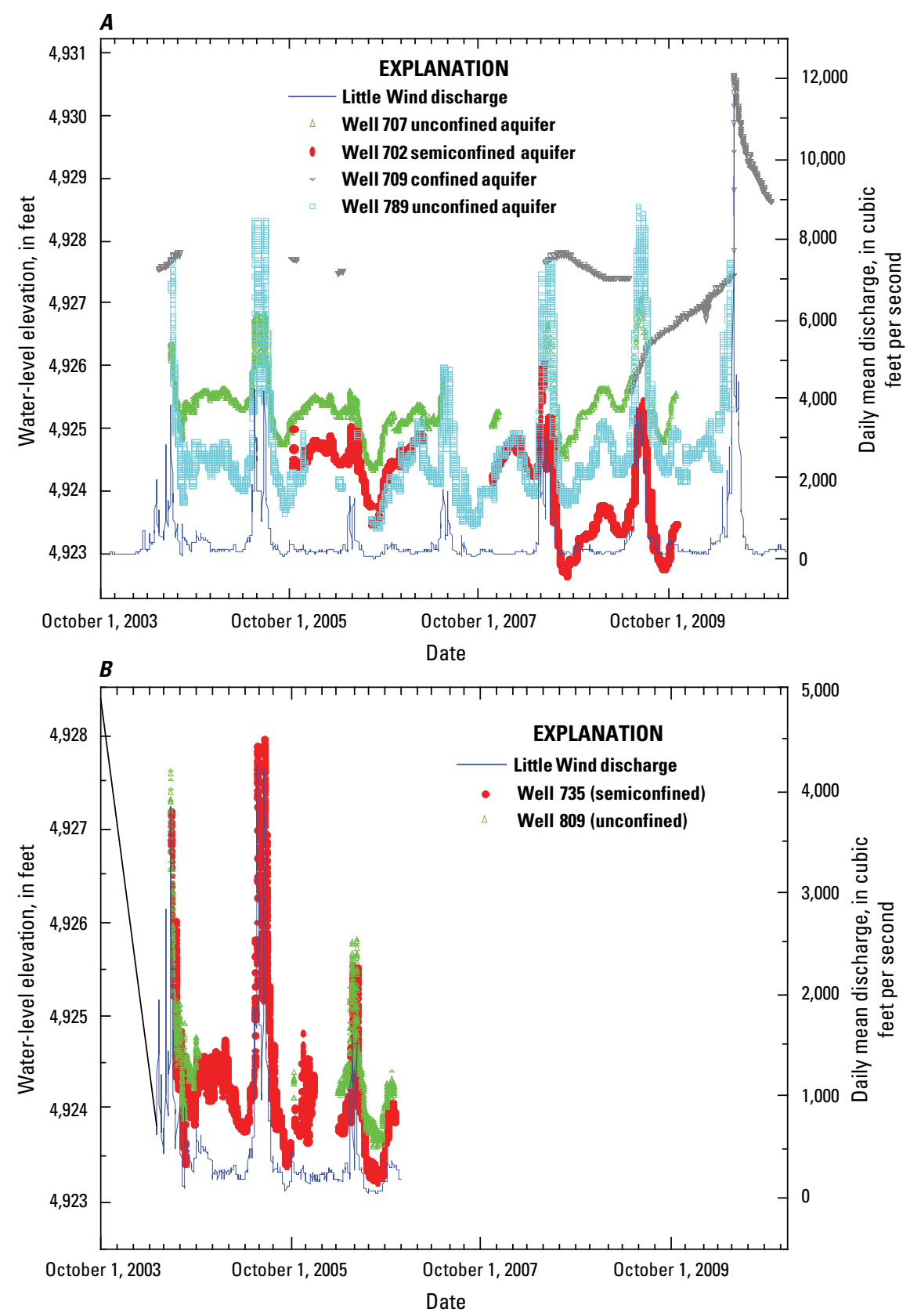

Figure 29. Graphs comparing the response in water elevations from monitoring wells completed in the different aquifers to river stage (discharge) in areas $A$, north and $B$, south of the Little Wind River, Riverton, Wyoming, Uranium Mill Tailings Remedial Action site study area. 
the Little Wind River directly south of DOE well 707. The water elevations in wells in the unconfined and intermediate semiconfined bedrock aquifers respond in a similar manner to changes in discharge in the Little Wind River. This relation indicates that these aquifers on both sides of the river are in hydraulic connection with the Little Wind River. On the north side of the river, the hydraulic head is consistently higher in the upper unconfined alluvial aquifer (DOE well 707) relative to the intermediate semiconfined bedrock aquifer (DOE well 702) indicating a potential for groundwater in the upper unconfined alluvial aquifer to flow down into the intermediate semiconfined bedrock aquifer. Also on the north side of the river, the limited data collected from DOE well 709 show that the hydraulic head is consistently higher in the lower confined bedrock aquifer relative to the two aquifers above it indicating no potential for groundwater to flow into it from the aquifers above it. On the south side of the river, the hydraulic head also appears to be consistently higher in the upper unconfined alluvial aquifer (DOE well 809) relative to the intermediate semiconfined bedrock aquifer (DOE well 735) indicating a potential for groundwater in the upper unconfined alluvial aquifer to flow down into the intermediate semiconfined bedrock aquifer.

A comparison of water elevations measured in the two wells screened in the upper unconfined alluvial aquifer north of the river indicates that during low flows in the Little Wind River, the water elevations in DOE well 707 are higher than in DOE well 789 indicating that groundwater is flowing toward the Little Wind River and has the potential to flow into it. During high flows in the Little Wind River associated with snowmelt, however, the water elevations in DOE well 789 are higher than in DOE well 707 indicating that groundwater from the upper unconfined alluvial aquifer cannot flow into the Little Wind River. A similar relation is observed with the more recent data measured by pressure transducers shown in figure 14. During most of the period of record (AprilNovember 2012), the water elevation in DOE well 707 is higher than in DOE well 789. In early June, however, during snowmelt runoff, the water elevations in the two wells are just about equal. This shows that, similar to the groundwaterelevation data presented in figure 29, groundwater in the upper unconfined alluvial aquifer has the potential to flow into the Little Wind River during low flows but not during high flows. The implication of this is that contaminant movement into the river from the upper unconfined alluvial aquifer may be occurring but that it could be seasonal.

Figure 30 shows the relation between water elevations measured in two wells in the intermediate semiconfined bedrock aquifer on opposite sides of the Little Wind River and discharge in the Little Wind River. Water elevations in both wells respond in a similar manner to changes in discharge in the Little Wind River indicating that this aquifer may be in hydraulic connection with the Little Wind River. What is interesting about this relation, however, is that during low flows, the water elevations in DOE well 702 are higher than those in DOE well 735 indicating a potential for groundwater to flow from the north side of the river to the south side of the river. During high flows caused by snowmelt the reverse can occur. In other words, the direction of groundwater flow in the intermediate semiconfined bedrock aquifer may vary seasonally.

In summary, the degree of hydraulic connection between the Little Wind River and the upper unconfined alluvial aquifer and the intermediate semiconfined bedrock aquifer on both sides of the river needs to be determined. The available water-elevation data indicate that, in the upper unconfined alluvial aquifer on the north side of the river, the hydraulic gradient during low flows in the Little Wind River is from the northwest to southeast toward the Little Wind River but reverses in the flood plain of the river during high flows associated with snowmelt runoff. If there is reversal in groundwater-flow direction, migration of the COCs and COPCs beneath or into the Little Wind River may occur seasonally instead of year round. This could have a major effect on the time it takes for the COCs to flow from the UMTRA site. The hydraulic gradient in the intermediate semiconfined bedrock aquifer during low flows in the Little Wind River is from north to south but also reverses during high flows associated with snowmelt runoff. The available water-quality data indicate that the contaminated groundwater plume is not affecting the water quality of the Little Wind River because the concentration of uranium measured at all DOE sampling sites on the Little Wind River, except for one value of $14.8 \mu \mathrm{g} / \mathrm{L}$ (site 796 on $9 / 8 / 1997$ ) has consistently been below $10 \mu \mathrm{g} / \mathrm{L}$. However, water-quality samples in groundwater and the Little Wind River are only collected twice a year, and concurrent samples collected from the groundwater and the river are limited.

The data gaps in amount of water-quality data available and the nature of the hydraulic connection between the upper unconfined alluvial aquifer and the intermediate semiconfined bedrock aquifer and between these two aquifers and the Little Wind River makes a quantitative understanding of the fate of the COCs in the riparian zone of the Little Wind River impossible. The following sampling schedule is suggested to better understand the hydraulic connection between the upper two aquifers and the Little Wind River and to determine if the COCs are migrating across the Little Wind River: quarterly to monthly groundwater-elevation and water-quality data (field properties, dissolved major ions, silica, and total and dissolved manganese, molybdenum, sulfate, and uranium) need to be collected from nested DOE wells 707, 702, and 709, located on the north side of the Little Wind River; nested DOE wells 706 and 735, located on the south side of the Little Wind River; and from the Little Wind River upstream and downstream from these groundwater wells. The groundwater-elevation data need to be compared with river-stage data measured in the Little Wind River near these groundwater wells. 


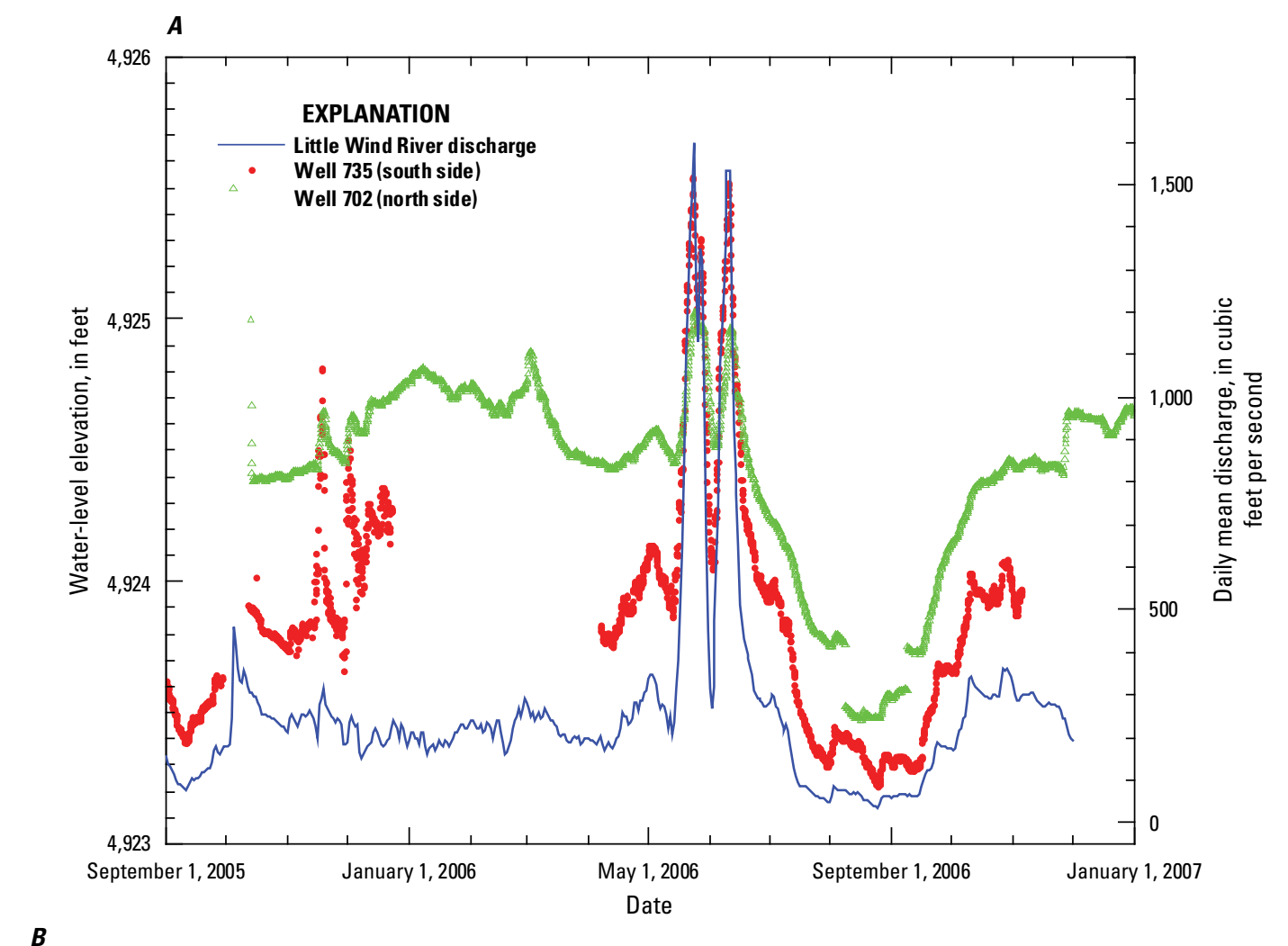

NORTH
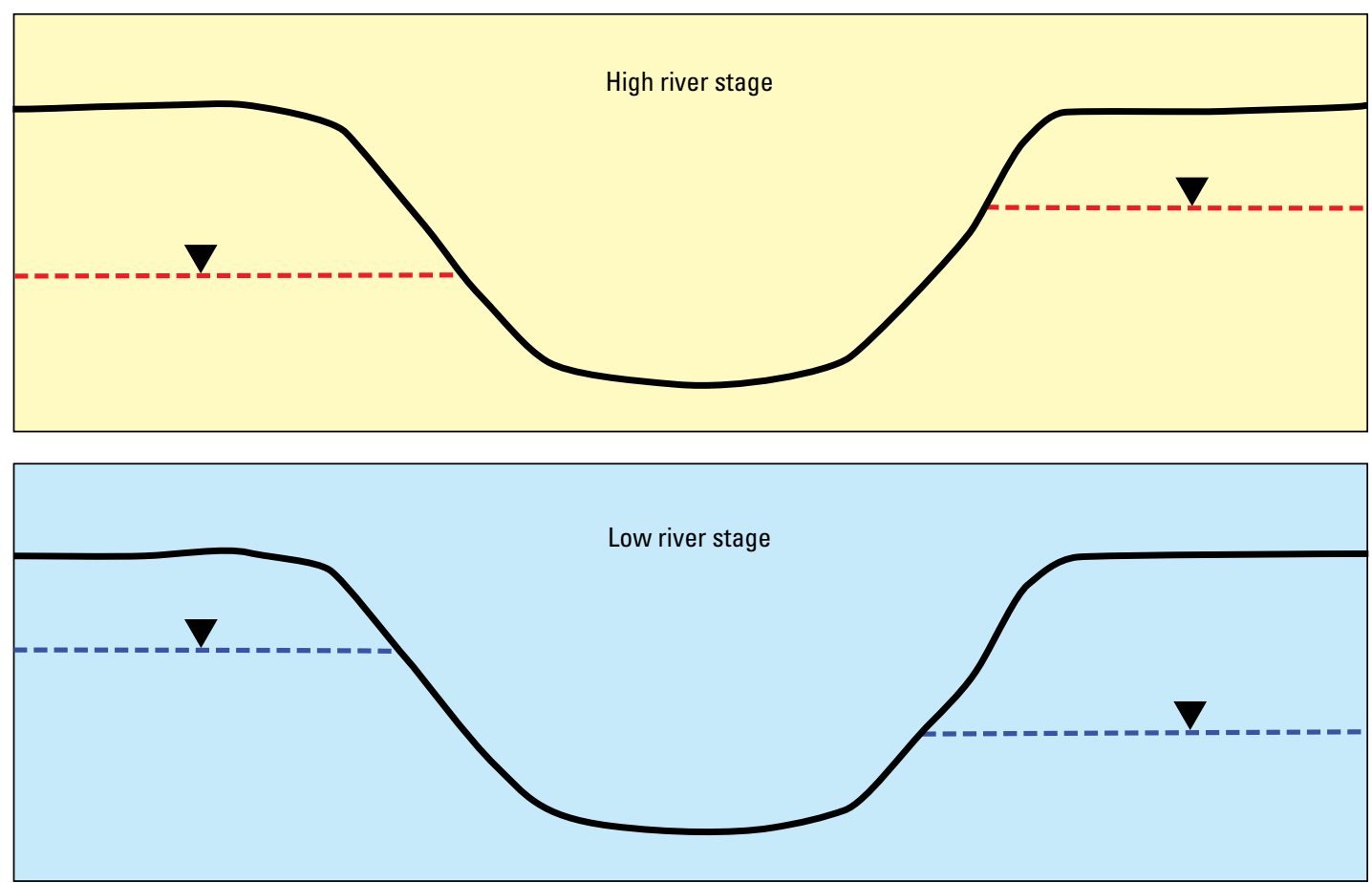

Figure 30. A, Comparison of water elevations in monitor wells completed in the intermediate semiconfined bedrock aquifer to the daily mean discharge in Little Wind River near Riverton, Wyoming. $B$, Schematic diagram of changes in seasonal water-elevation levels (dashed red and blue lines) in the intermediate semiconfined bedrock aquifer. 


\section{June 2010 Flooding of the Little Wind River}

Flooding of the Little Wind River in June 2010 resulted in large increases in the concentrations of manganese, molybdenum, sulfate, and uranium in DOE wells 826,788 , 707, and 789 (fig. 31). All of these wells are in the upper unconfined surficial aquifer, and this increase in concentration was not observed in any other wells. Data collected from DOE well 828 are included on these plots to define the horizontal extent of the increase in these COCs. These plots indicate that high concentrations of each COC still existed in each well by the end of the year. The reason for this increase is not known, but the results of the saturation-index calculations (table 2) and the fact that these wells are in the area of the contaminated plume suggests three, not necessarily unrelated, mechanisms for the cause of the post-flood increase in the concentrations of the COCs. In other words, multiple mechanisms could be responsible for the increase in concentration of the COCs.

One possible mechanism for the increase in COCs is the dissolution of precipitated minerals in the upper unconfined alluvial aquifer. The groundwater in the area of DOE well 707 on February 18, 1996, and February 9, 1997, was saturated with respect to or in equilibrium with barite, gypsum, rhodochrosite, and manganite (manganite only on February 18, 1996), whereas water in the Little Wind River is undersaturated with respect to these minerals. So it is possible that as water from the Little Wind River infiltrated into the groundwater adjacent to the river, the minerals that may have precipitated out of groundwater would be dissolved by infiltrating river water.

The second possible mechanism for the increase in COCs is that perhaps at some point in the past similar flooding occurred and caused the water table to rise up to or near the surface. As the water table declined to the elevations measured during the years preceding the June 2010 flooding, due in part to evaporation, minerals (efflorescent crusts or salts) containing the COCs could have precipitated as evaporation proceeded. The rising water table that occurred during the June 2010 flooding would then have dissolved the minerals formed in the upper soil profile.

A third possible mechanism is that soils in the flooded area may contain high concentrations of COCs in solid phases due to wind deposition of particles from the ore storage pads. Sediment samples collected from West Side Creek and Oxbow Lake by a consultant hired by the WREQC (D. Haire, U.S. Department of Energy, written commun., 2011) and soil samples collected from the top 5 centimeters (almost 2 inches) of the soil profile at various locations around the UMTRA site (Smith and Sweat, 2012) and analyzed for the COCs indicated that the concentration of COCs in these samples was within the range for soils found throughout the State of Wyoming. Therefore, this is not a likely mechanism for the high concentrations following the June 2010 flooding.

In summary, the cause of the large increase in the concentration of manganese, molybdenum, sulfate, and uranium in DOE wells $707,826,788$, and 789 following the flooding of the
Little Wind River in June 2010 needs to be determined. How long will these increased concentrations last? Will this increase happen again when flooding of this magnitude occurs at some point in the future? Related to the last question, is this actually flushing the COCs from the aquifer or is there a reservoir of COCs in the soil that will always cause an increase when flooding occurs? The cause of this increase needs to be determined because it has relevance to the frequency of sampling needed.

It is suggested that quarterly to monthly sampling for field properties $(\mathrm{pH}$, specific conductance, dissolved oxygen, and water temperature), dissolved major ions $\left(\mathrm{Ca}^{2+}, \mathrm{Mg}^{2+}, \mathrm{Na}^{+}\right.$, $\mathrm{K}^{+}, \mathrm{HCO}_{3}^{-}$, and $\mathrm{Cl}^{-}$), silica, and total and dissolved manganese, molybdenum, sulfate, and uranium be done in DOE wells $702,706,707,709,735,788,789$, and 809 . In addition, if the concentration of dissolved oxygen is zero, then an additional measurement of redox potential, or a redox couple such as nitrate/ammonia or $\mathrm{Fe}^{+2} / \mathrm{Fe}^{+3}$, should be made. Modeling of this data with PHREEQC could help determine if seasonal changes in either the speciation of the COCs occur (important for determining if sorption occurs) and (or) precipitation/ dissolution of minerals containing the COCs occur. Depth profiles of soil at 1-foot increments could also be collected adjacent to these wells down to the water table and analyzed for their minerals content to determine if any of the solid phases that the PHREEQC modeling indicates could form actually exist.

A better understanding of the distribution of COCs in vegetation is needed because vegetation adjacent to the Little Wind River is harvested by tribal members for various cultural uses (Travis Shakespeare, WREQC, oral commun., 2012). Sampling of vegetation adjacent to the Little Wind River with root depths that could intercept the water table and remobilized COCs could be done. Samples would be analyzed for COCs and associated trace elements.

\section{Pattern-Recognition Modeling}

The extent of contaminated groundwater among the three aquifers, the groundwater-surface water interaction between the three aquifers and the Little Wind River, and the June 2010 flooding of the Little Wind River were also evaluated using pattern-recognition modeling software (Infometrix, 2010). Long-term water-quality monitoring at selected UMTRA sites can generate large, multivariate datasets that can be accessed through DOE's Geospatial Environmental Mapping System (GEMS; http://gems.lm.doe.gov/imf/imf.jsp? site=rivertonpr ocessing\&title=Riverton). The dominant use of these waterquality datasets is for compliance monitoring, particularly when natural attenuation and groundwater flushing is the approved remediation action.

Although compliance monitoring is an important role for the COC data, multivariate data analysis of the entire dataset can be used to extract patterns that may be important to understanding the progress of natural attenuation process(es) and (or) geochemical fingerprints at a particular UMTRA site. This additional information can be used in conjunction 
A
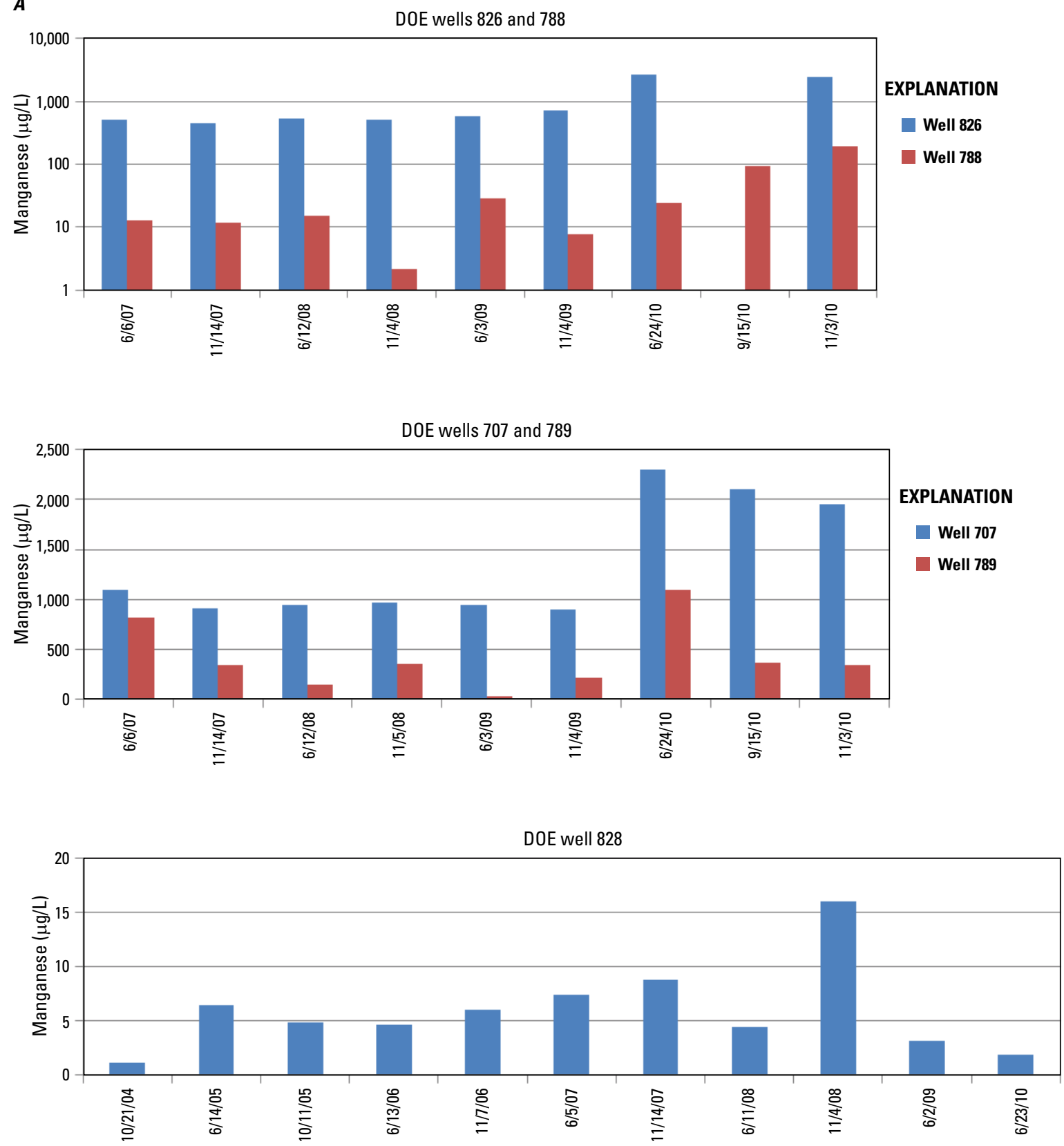

Figure 31. Effects of the June 2010 flooding of the Little Wind River on the concentration of $A$, manganese; $B$, molybdenum; $C$, sulfate; and $D$, uranium in selected U.S. Department of Energy wells in the upper unconfined alluvial aquifer. $\mu \mathrm{g} / \mathrm{L}$, micrograms per liter. 

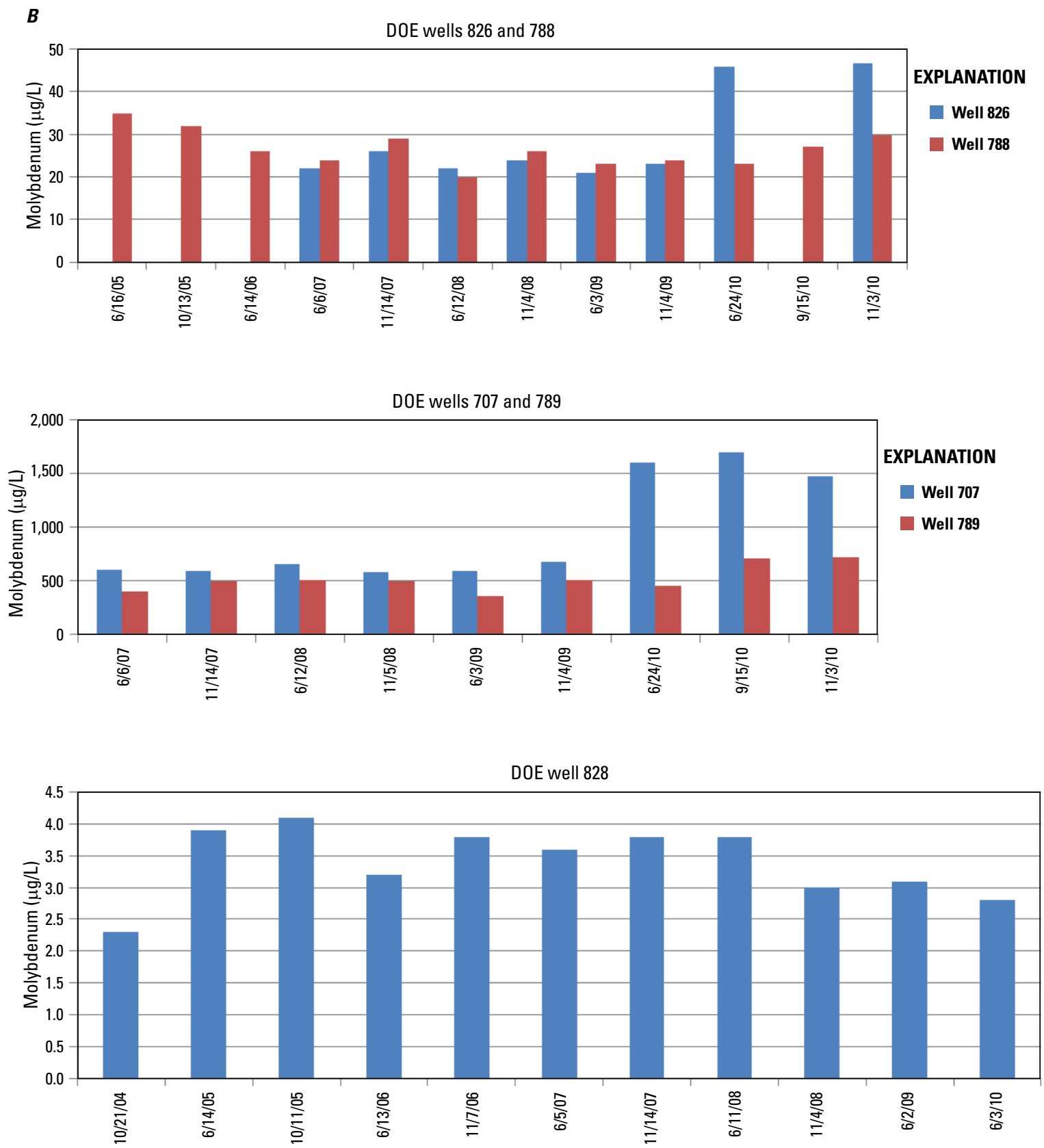

Figure 31. Effects of the June 2010 flooding of the Little Wind River on the concentration of $A$, manganese; $B$, molybdenum; $C$, sulfate; and $D$, uranium in selected U.S. Department of Energy wells in the upper unconfined alluvial aquifer. $\mu \mathrm{g} / \mathrm{L}$, micrograms per liter.-Continued 

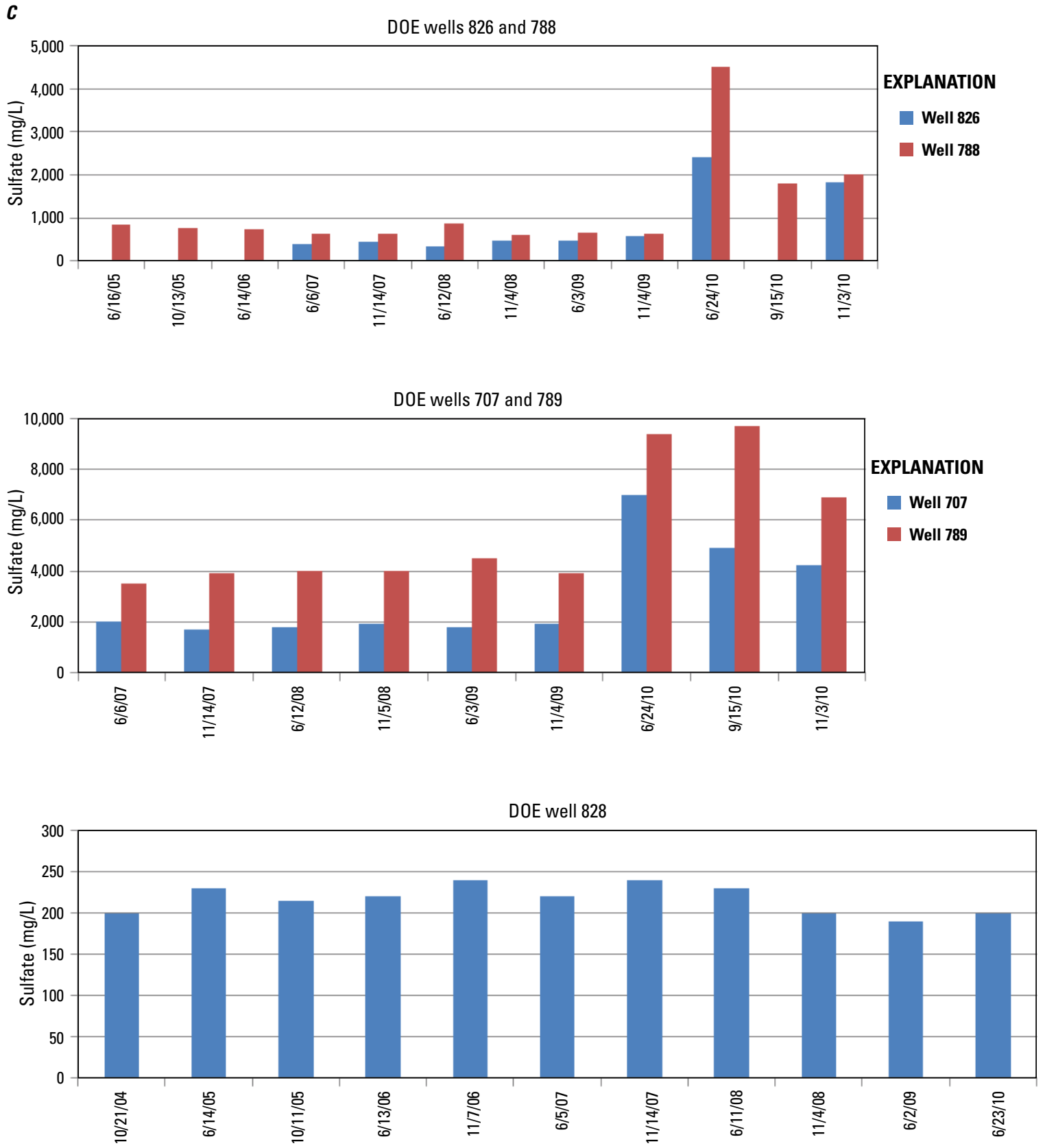

Figure 31. Effects of the June 2010 flooding of the Little Wind River on the concentration of $A$, manganese; $B$, molybdenum; $C$, sulfate; and $D$, uranium in selected U.S. Department of Energy wells in the upper unconfined alluvial aquifer. $\mathrm{mg} / \mathrm{L}$, milligrams per liter.-Continued 

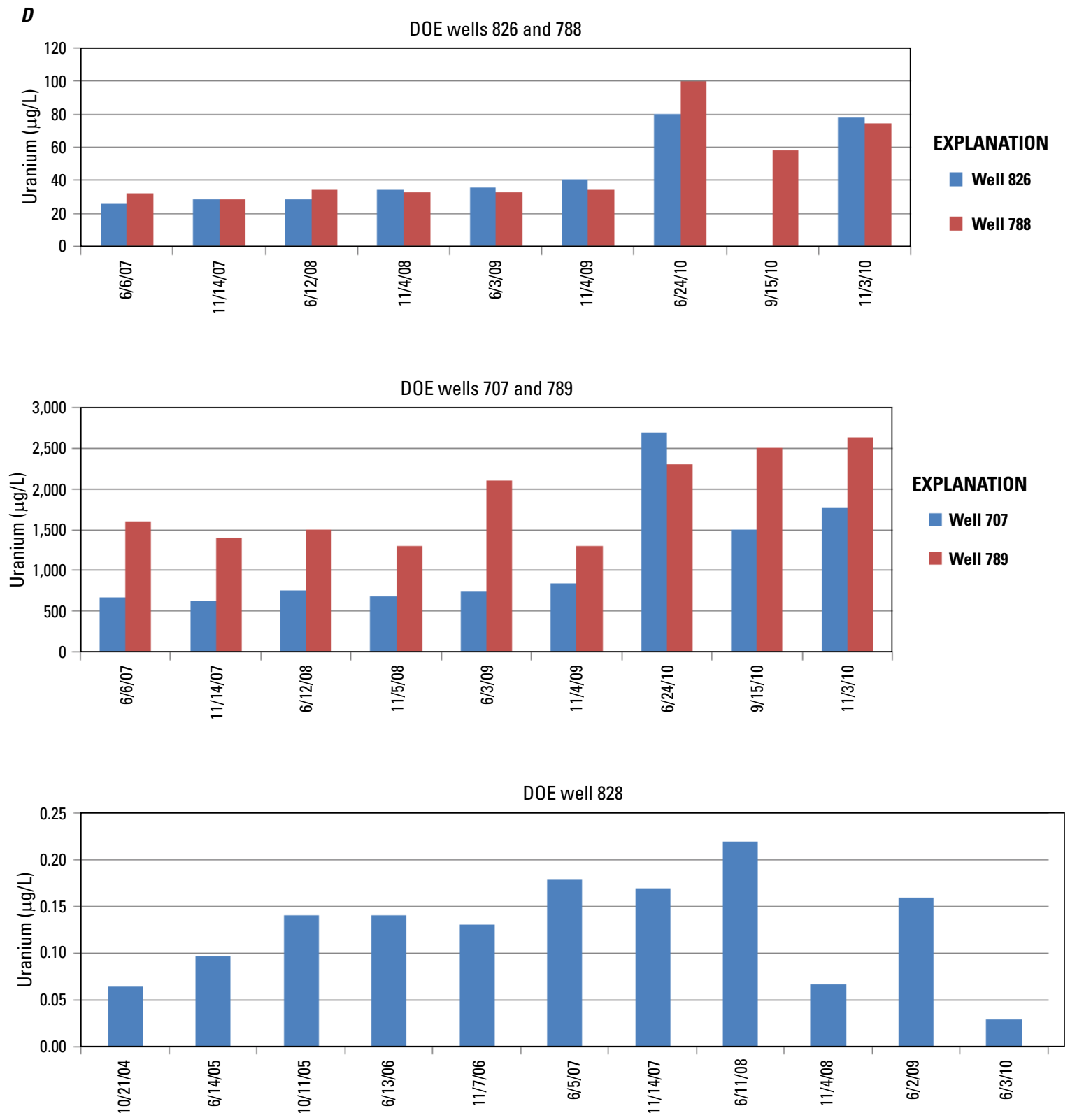

Figure 31. Effects of the June 2010 flooding of the Little Wind River on the concentration of $A$, manganese; $B$, molybdenum; $C$, sulfate; and $D$, uranium in selected U.S. Department of Energy wells in the upper unconfined alluvial aquifer. $\mu \mathrm{g} / \mathrm{L}$, micrograms per liter.-Continued 
with $\mathrm{COC}$ monitoring to provide more insightful legacy management decisions and performance assessments. Questions answered by multivariate data analysis might include (1) What are the important geochemical processes controlling the COCs in the contaminated aquifer(s), and do these processes change on a seasonal or annual basis? (2) Do other potential sources of contamination exist on the site that could have similar COCs? (3) Do different aquifers of a site (that is confined compared to unconfined) display different geochemical processes, and do these processes support hydraulic isolation or seasonal mixing? (4) Do surface-water monitoring sites indicate any long-term or seasonal influence from groundwater discharge that may not be evident from just COC monitoring? (5) Do long-term changes in multiple geochemical characteristics at a particular monitoring site indicate a return to baseline geochemical processes in the previously contaminated aquifer?

Pattern-recognition modeling techniques have been used in a variety of environmental applications where multivariate chemical databases required interpretation in the context of multiple environmental processes (for example, differentiating between natural and anthropogenic trace-metal signatures). Naftz (1996a,b) applied pattern-recognition modeling techniques to a large chemical database generated from the U.S. Department of the Interior's National Irrigation Water Quality Program to identify water that could pose a selenium hazard to waterfowl. Pattern-recognition techniques have been used for geochemical interpretation of organic biomarker signals (Christie and others, 1984). Archeological studies have used pattern-recognition techniques to discriminate marble sources (Mello and others, 1988) and classify ancient ceramics using major- and trace-element data (Heydorn and Thuesen, 1989). Pyrolysis-mass spectrometry analyses coupled with pattern-recognition techniques were useful in differentiating the origin of smoke aerosols (Voorhees and Tsao, 1985) and humic materials (MacCarthy and others, 1985). Also, patternrecognition techniques applied to the elemental composition of oils have been used to determine spill-source identification in an oceanic setting (Duewer and others, 1975). In a hydrologic application, pattern-recognition techniques have been used to optimize multi-element groundwater-quality monitoring programs at an oil-shale retort site (Meglen and Erickson, 1983). More recently, pattern-recognition modeling has been applied to an UMTRA site in western Colorado to identify geochemical and hydrologic footprints controlling uranium removal (U.S. Department of Energy, 2001) and to an active uranium mill in southeastern Utah to investigate off-site migration of ore material (Naftz and others, 2011).

Monitoring data for the time period of April 1993 through November 2011 were downloaded from the DOE GEMS database. This dataset included samples from the three aquifers (19 wells in the confined aquifer, 12 wells in the semiconfined aquifer, and 19 wells in the unconfined aquifer) and 9 surface-water monitoring sites in the study area. Chemical constituents included in the database were total alkalinity, manganese, molybdenum, oxidation-reduction potential, specific conductance, sulfate, water temperature, uranium, and $\mathrm{pH}$. A total of 529 samples were included in this multivariate database, and the raw data can be found in table 6. Concentrations less than the lower reporting limit were assigned a value 0.75 of the lower reporting limit (LRL). If the LRL varied over time, the highest LRL was used. Based on visual inspection of histograms constructed for each variable, $\log _{10}$ transformation was applied to manganese, molybdenum, specific conductance, sulfate, and uranium data to achieve a more normal data distribution prior to pattern recognition modeling.

Principal component analysis (PCA) was applied to the Riverton UMTRA database (table 6). Variance scale preprocessing (dividing each constituent value by the constituent standard deviation) was applied prior to PCA to normalize the different measurement units (for example, microsiemens per centimeter or milligrams per liter). A threefactor model was selected and explained greater than 90 percent of the total variance. The varimax rotated loadings for the three factors are shown in figure 32 with loading values (unitless) $\geq 0.15$ or $\leq-0.15$ considered significant. Significant positive loadings associated with factor 1 include $\mathrm{pH}$, water temperature (T), and specific conductance (SC), and negative loadings include alkalinity (ALK), molybdenum (Mo), manganese (Mn), and uranium (U) (fig. 32A). The chemical elements associated with factor 1 were interpreted to be associated with noncontaminated surface-water and groundwater samples. This classification is primarily due to the negative loadings associated with primary COCs previously identified at the site, including molybdenum, manganese, and uranium. Significant loadings associated with factor 2 include $\mathrm{pH}$, manganese, alkalinity, sulfate, specific conductance, and uranium (fig. 32A). The chemical elements associated with factor 2 were interpreted to identify slightly contaminated, suboxic groundwater, likely reflecting mixing between the unconfined aquifer and the two deeper aquifers (semiconfined and confined). Significant loadings associated with factor 3 include the constituents uranium, $\mathrm{pH}$, and ORP (fig. 32B). The positive loading for uranium in factor 3 was interpreted to identify groundwater contaminated by uranium. The inclusion of significant positive loadings for $\mathrm{pH}$ and ORP in factor 3 indicates that uranium would be highly mobile under these conditions, as well.

The scores for the first two factors were plotted (fig. 33) to evaluate the occurrence of distinct clusters in the data that could provide insight into the potential hydraulic connection and resulting mixing between the three aquifers within the study area. The majority of water samples collected from confined aquifers at the Riverton UMTRA site contain high factor 1 scores and low factor 2 scores (fig. 33A) indicating little or no hydraulic connection between the confined aquifer and the contaminated (semiconfined and unconfined) aquifers at the site. Seven water samples plot outside of the dominant group of confined aquifer samples. Only two of these samples have slightly elevated factor 2 scores indicating possible contamination. These samples were collected from wells 441 
Table 6. Water-quality data used in pattern-recognition analysis of Riverton, Wyoming, Uranium Mill Tailings Remedial Action (UMTRA) site.

[mg/L, milligram per liter; $\mathrm{mV}$, millivolt; $\mu \mathrm{S} / \mathrm{cm}$, microsiemens per centimeter]

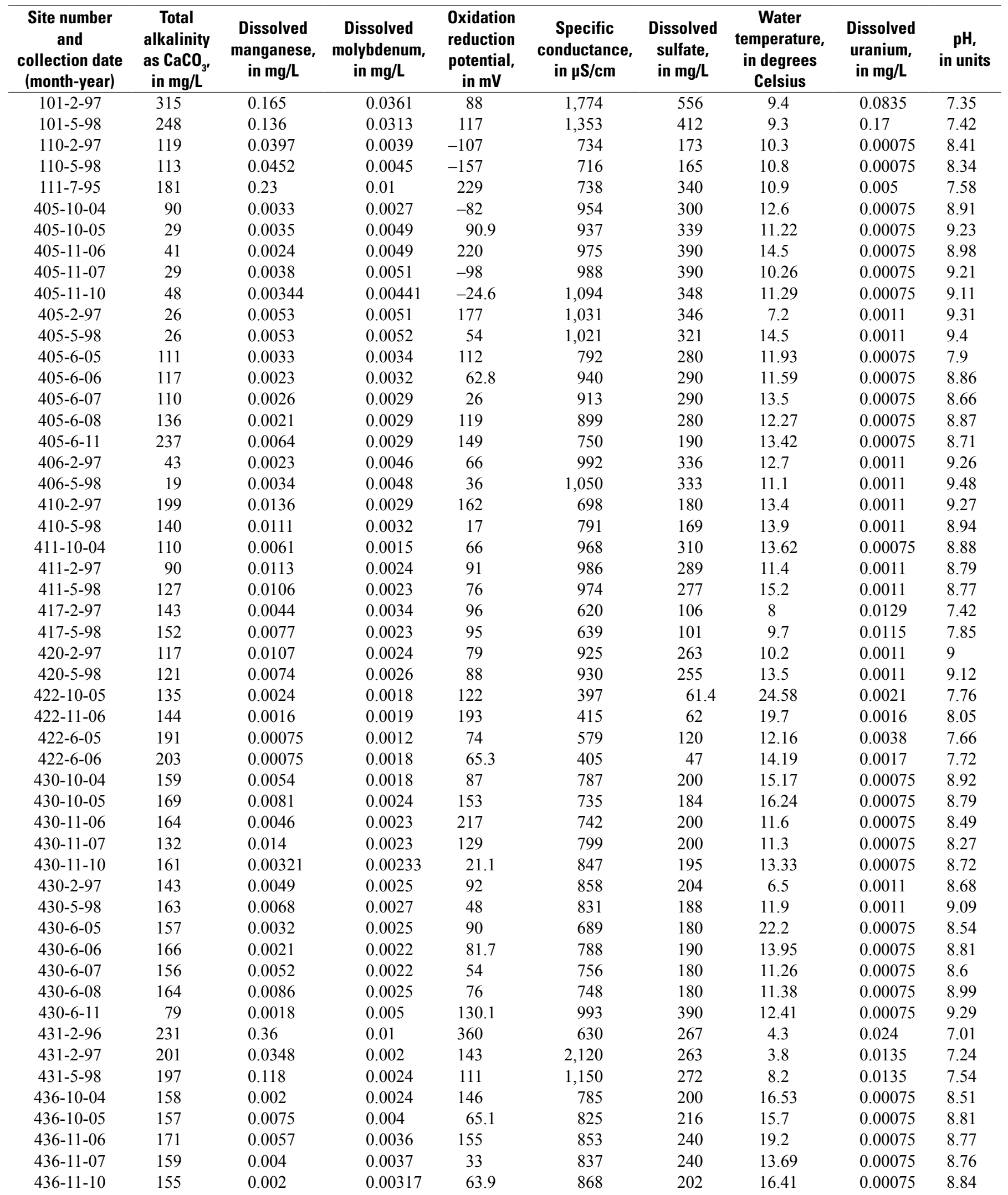


Table 6. Water-quality data used in pattern-recognition analysis of Riverton, Wyoming, Uranium Mill Tailings Remedial Action (UMTRA) site.-Continued

[mg/L, milligram per liter; $\mathrm{mV}$, millivolt; $\mu \mathrm{S} / \mathrm{cm}$, microsiemens per centimeter]

\begin{tabular}{|c|c|c|c|c|c|c|c|c|c|}
\hline $\begin{array}{l}\text { Site number } \\
\text { and } \\
\text { collection date } \\
\text { (month-year) }\end{array}$ & $\begin{array}{c}\text { Total } \\
\text { alkalinity } \\
\text { as } \mathrm{CaCO}_{3^{\prime}} \\
\text { in } \mathrm{mg} / \mathrm{L}\end{array}$ & $\begin{array}{c}\text { Dissolved } \\
\text { manganese, } \\
\text { in } \mathrm{mg} / \mathrm{L}\end{array}$ & $\begin{array}{c}\text { Dissolved } \\
\text { molybdenum, } \\
\text { in } \mathrm{mg} / \mathrm{L}\end{array}$ & $\begin{array}{c}\text { Oxidation } \\
\text { reduction } \\
\text { potential, } \\
\text { in } \mathrm{mV}\end{array}$ & $\begin{array}{c}\text { Specific } \\
\text { conductance, } \\
\text { in } \mu \mathrm{S} / \mathrm{cm}\end{array}$ & $\begin{array}{l}\text { Dissolved } \\
\text { sulfate, } \\
\text { in } \mathrm{mg} / \mathrm{L}\end{array}$ & $\begin{array}{c}\text { Water } \\
\text { temperature, } \\
\text { in degrees } \\
\text { Celsius }\end{array}$ & $\begin{array}{l}\text { Dissolved } \\
\text { uranium, } \\
\text { in } \mathrm{mg} / \mathrm{L}\end{array}$ & $\begin{array}{c}\text { pH, } \\
\text { in units }\end{array}$ \\
\hline $436-6-06$ & 174 & 0.005 & 0.0032 & 152.2 & 912 & 230 & 23.54 & 0.00075 & 8.76 \\
\hline $436-6-07$ & 160 & 0.0055 & 0.0039 & 75 & 855 & 230 & 21.97 & 0.00075 & 8.57 \\
\hline $436-6-08$ & 156 & 0.012 & 0.004 & 76 & 857 & 230 & 27.49 & 0.00075 & 8.77 \\
\hline $440-5-98$ & 84 & 0.0107 & 0.0083 & 71 & 975 & 280 & 9.6 & 0.0011 & 7.14 \\
\hline $441-5-98$ & 256 & 0.24 & 0.002 & 85 & 1,907 & 656 & 9.7 & 0.0203 & 7.37 \\
\hline $442-2-97$ & 102 & 0.0233 & 0.0026 & 182 & 943 & 290 & 9.1 & 0.0011 & 9.46 \\
\hline $442-5-98$ & 134 & 0.0191 & 0.0022 & 83 & 986 & 274 & 11.5 & 0.0011 & 8.97 \\
\hline $444-2-97$ & 156 & 0.0041 & 0.0034 & 177 & 894 & 226 & 8.2 & 0.0011 & 8.85 \\
\hline 446-10-05 & 163 & 0.005 & 0.0025 & 162.4 & 643 & 136 & 13.28 & 0.00075 & 8.42 \\
\hline $446-2-97$ & 195 & 0.005 & 0.0026 & 90 & 679 & 145 & 7.6 & 0.0011 & 8.83 \\
\hline $446-5-98$ & 156 & 0.002 & 0.003 & 31 & 712 & 135 & 9.9 & 0.0011 & 9.14 \\
\hline $446-6-05$ & 158 & 0.0026 & 0.0028 & 138 & 630 & 140 & 11.86 & 0.00075 & 8.34 \\
\hline $448-2-97$ & 259 & 0.0082 & 0.0033 & 90 & 787 & 187 & 4.5 & 0.0011 & 8.88 \\
\hline $448-5-98$ & 151 & 0.0117 & 0.0036 & 53 & 805 & 179 & 13 & 0.0011 & 9.08 \\
\hline $451-2-97$ & 143 & 0.0136 & 0.0031 & 184 & 840 & 223 & 6.4 & 0.0011 & 8.84 \\
\hline $452-2-97$ & 158 & 0.0518 & 0.003 & -1 & 1,207 & 330 & 7.4 & 0.0011 & 8.18 \\
\hline $452-5-98$ & 133 & 0.104 & 0.0034 & -85 & 1,254 & 362 & 14.2 & 0.0011 & 8.44 \\
\hline $453-2-97$ & 135 & 0.0048 & 0.0029 & 197 & 482 & 229 & 6.4 & 0.0011 & 8.7 \\
\hline $453-5-98$ & 157 & 0.0051 & 0.0031 & 50 & 946 & 223 & 11.9 & 0.0011 & 9.06 \\
\hline $460-11-06$ & 165 & 0.00075 & 0.0031 & 36 & 702 & 170 & 27.4 & 0.00075 & 8.76 \\
\hline $460-11-07$ & 194 & 0.00075 & 0.0031 & -10 & 716 & 170 & 20.4 & 0.00075 & 8.89 \\
\hline $460-11-10$ & 157 & 0.002 & 0.00285 & 99.4 & 807 & 181 & 22.89 & 0.00075 & 8.9 \\
\hline $460-6-05$ & 158 & 0.00075 & 0.0034 & 87 & 612 & 160 & 20.06 & 0.00075 & 8.76 \\
\hline $460-6-06$ & 174 & 0.00075 & 0.0028 & 59 & 726 & 160 & 24.62 & 0.00075 & 8.79 \\
\hline $460-6-07$ & 165 & 0.0016 & 0.0025 & 27 & 704 & 160 & 21.38 & 0.00075 & 8.41 \\
\hline $460-6-08$ & 169 & 0.0015 & 0.003 & 69.6 & 701 & 160 & 17.79 & 0.00075 & 8.07 \\
\hline $460-6-11$ & 175 & 0.00075 & 0.0029 & 203.6 & 715 & 170 & 18.19 & 0.00075 & 8.77 \\
\hline $700-2-96$ & 279 & 0.05 & 0.01 & 284 & 757 & 436 & 5.2 & 0.025 & 7.2 \\
\hline $700-2-97$ & 277 & 0.0049 & 0.0042 & 83 & 1,534 & 453 & 6.6 & 0.0094 & 7.35 \\
\hline $700-5-98$ & 267 & 0.00075 & 0.0037 & 75 & 1,622 & 450 & 6.3 & 0.0135 & 7.29 \\
\hline $705-10-04$ & 62 & 0.00075 & 0.0031 & 220 & 1,319 & 450 & 10.47 & 0.00075 & 8.26 \\
\hline $705-10-05$ & 58 & 0.005 & 0.0027 & 83.7 & 1,202 & 422 & 9.86 & 0.00075 & 8.42 \\
\hline $705-11-06$ & 62 & 0.043 & 0.0029 & 29 & 1,240 & 480 & 11.72 & 0.00075 & 8.27 \\
\hline $705-11-07$ & 59 & 0.0078 & 0.0027 & -73 & 1,246 & 470 & 9.3 & 0.00075 & 8.21 \\
\hline $705-11-10$ & 51 & 0.0303 & 0.00287 & 27.8 & 1,349 & 414 & 7.96 & 0.00075 & 8.37 \\
\hline $705-2-96$ & 80 & 0.01 & 0.01 & 371 & 881 & 442 & 9.2 & 0.007 & 8.75 \\
\hline $705-4-93$ & 64 & 0.02 & 0.01 & 433 & 846 & 369 & 8.3 & 0.00075 & 8.81 \\
\hline
\end{tabular}


Table 6. Water-quality data used in pattern-recognition analysis of Riverton, Wyoming, Uranium Mill Tailings Remedial Action (UMTRA) site.-Continued

[mg/L, milligram per liter; $\mathrm{mV}$, millivolt; $\mu \mathrm{S} / \mathrm{cm}$, microsiemens per centimeter]

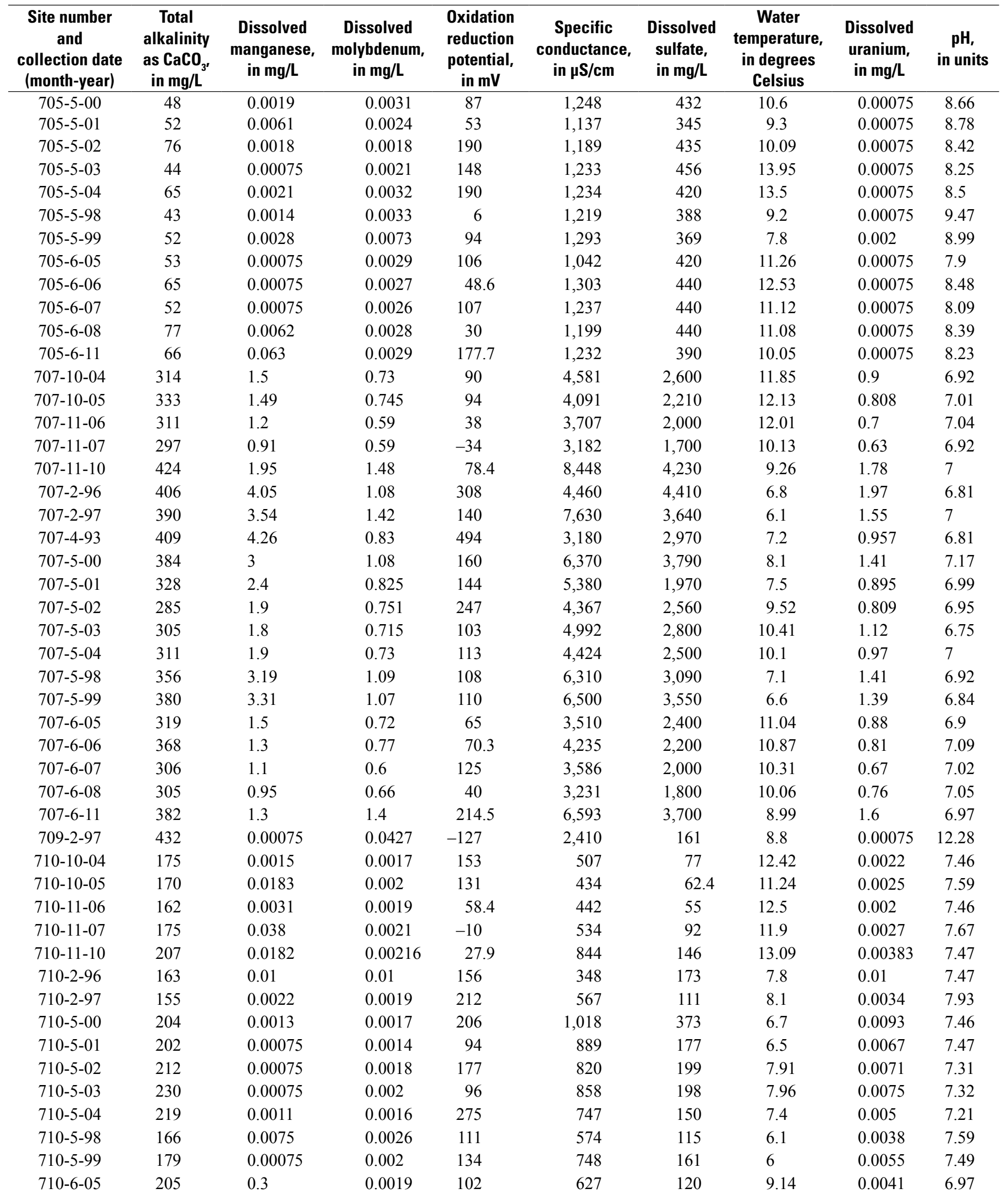


Table 6. Water-quality data used in pattern-recognition analysis of Riverton, Wyoming, Uranium Mill Tailings Remedial Action (UMTRA) site.-Continued

[mg/L, milligram per liter; $\mathrm{mV}$, millivolt; $\mu \mathrm{S} / \mathrm{cm}$, microsiemens per centimeter $]$

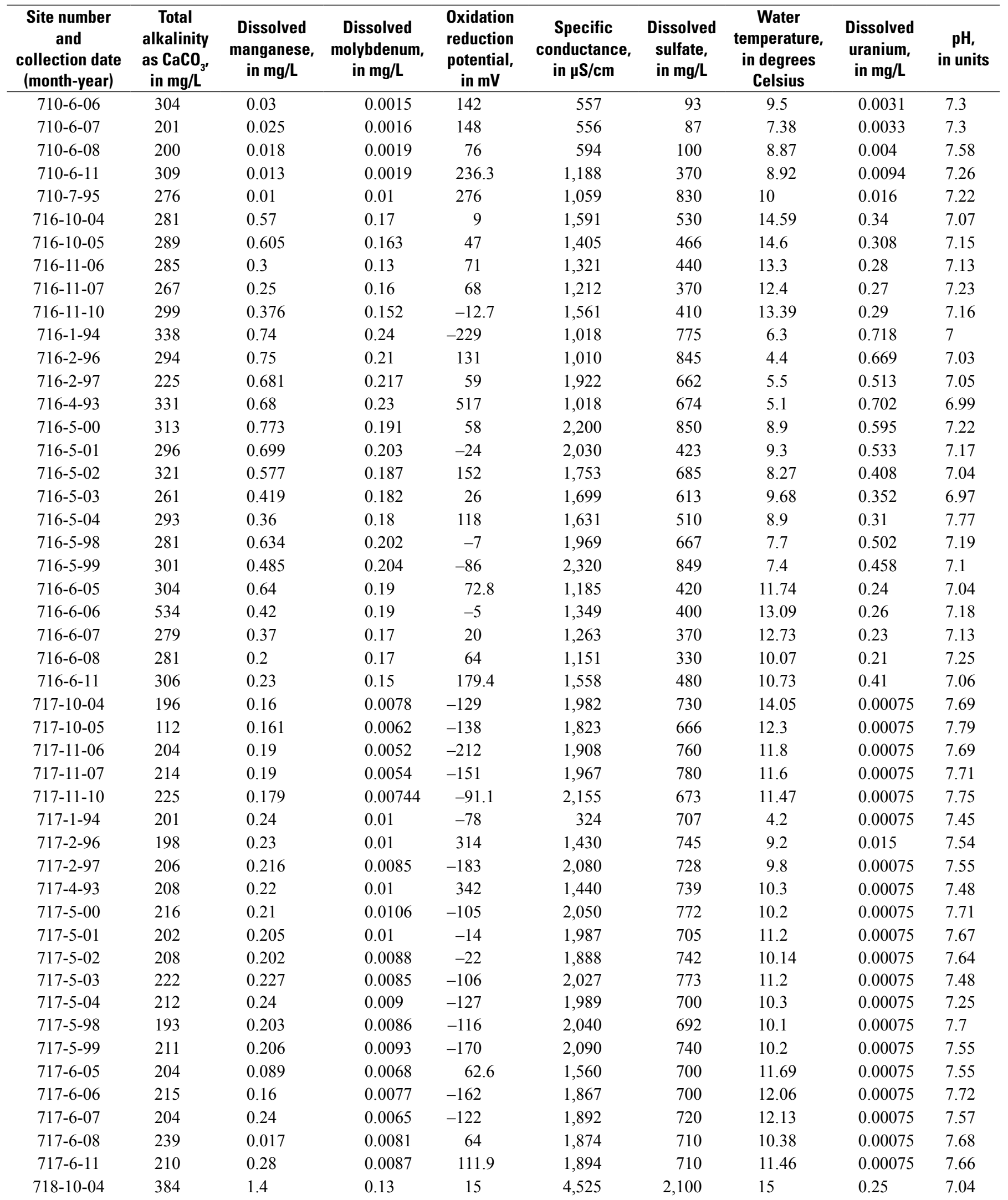


Table 6. Water-quality data used in pattern-recognition analysis of Riverton, Wyoming, Uranium Mill Tailings Remedial Action (UMTRA) site.-Continued

[mg/L, milligram per liter; $\mathrm{mV}$, millivolt; $\mu \mathrm{S} / \mathrm{cm}$, microsiemens per centimeter]

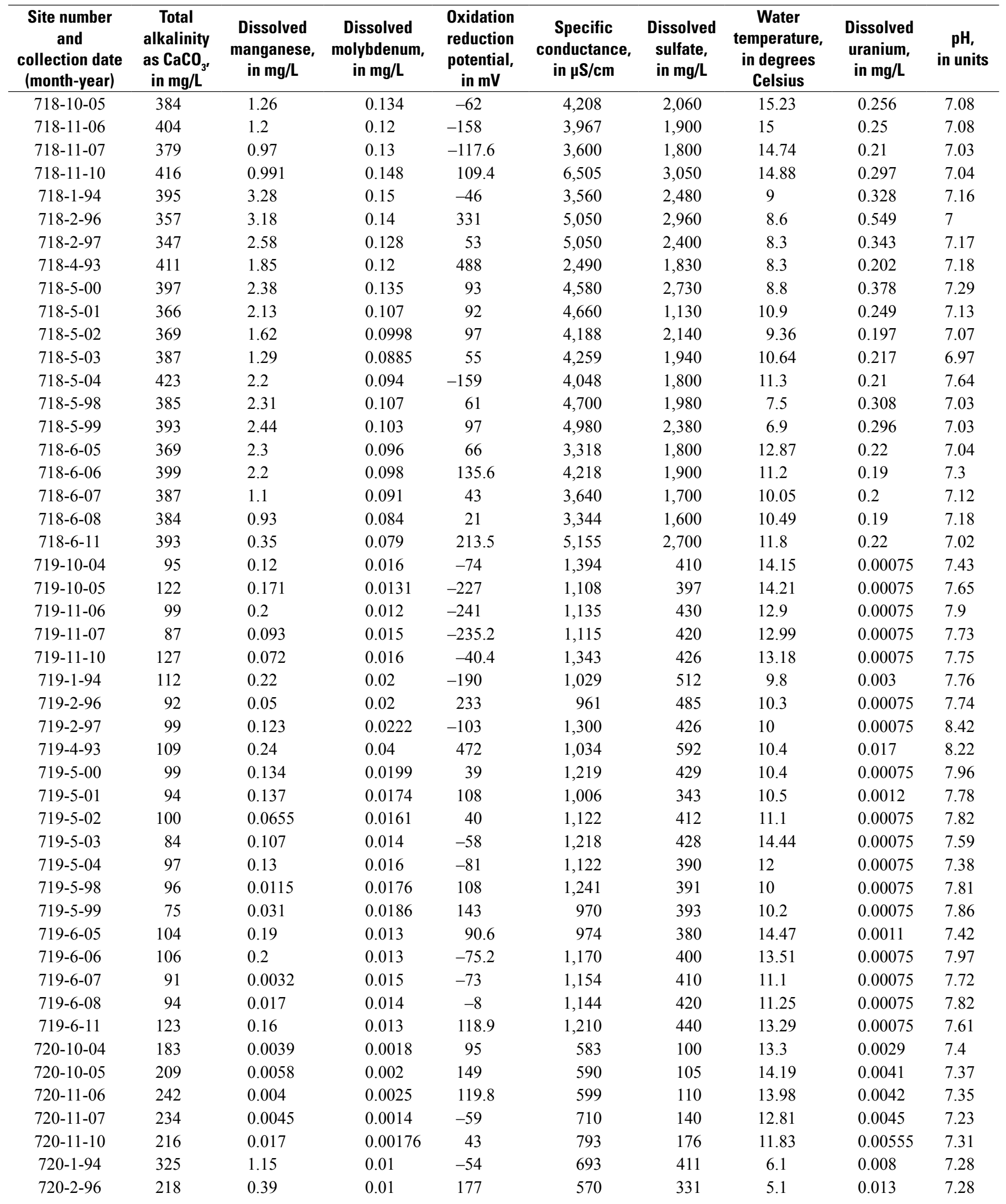


Table 6. Water-quality data used in pattern-recognition analysis of Riverton, Wyoming, Uranium Mill Tailings Remedial Action (UMTRA) site.-Continued

[mg/L, milligram per liter; $\mathrm{mV}$, millivolt; $\mu \mathrm{S} / \mathrm{cm}$, microsiemens per centimeter]

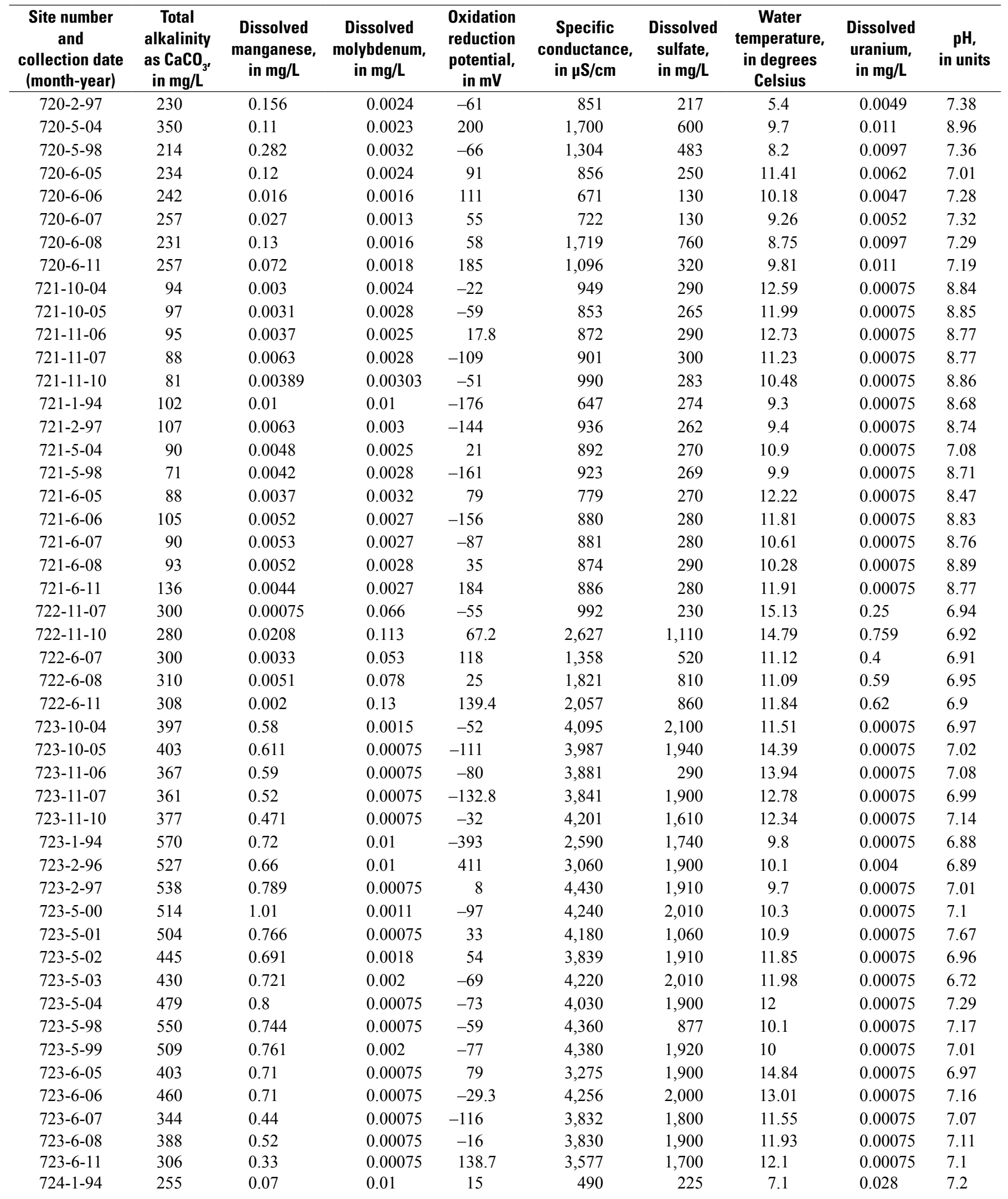


Table 6. Water-quality data used in pattern-recognition analysis of Riverton, Wyoming, Uranium Mill Tailings Remedial Action (UMTRA) site.-Continued

[mg/L, milligram per liter; $\mathrm{mV}$, millivolt; $\mu \mathrm{S} / \mathrm{cm}$, microsiemens per centimeter]

\begin{tabular}{|c|c|c|c|c|c|c|c|c|c|}
\hline $\begin{array}{l}\text { Site number } \\
\text { and } \\
\text { collection date } \\
\text { (month-year) }\end{array}$ & $\begin{array}{c}\text { Total } \\
\text { alkalinity } \\
\text { as } \mathrm{CaCO}_{3^{\prime}} \\
\text { in } \mathrm{mg} / \mathrm{L}\end{array}$ & $\begin{array}{c}\text { Dissolved } \\
\text { manganese, } \\
\text { in } \mathrm{mg} / \mathrm{L}\end{array}$ & $\begin{array}{c}\text { Dissolved } \\
\text { molybdenum, } \\
\text { in } \mathrm{mg} / \mathrm{L}\end{array}$ & $\begin{array}{c}\text { Oxidation } \\
\text { reduction } \\
\text { potential, } \\
\text { in } \mathrm{mV}\end{array}$ & $\begin{array}{c}\text { Specific } \\
\text { conductance, } \\
\text { in } \mu S / c m\end{array}$ & $\begin{array}{l}\text { Dissolved } \\
\text { sulfate, } \\
\text { in } \mathrm{mg} / \mathrm{L}\end{array}$ & $\begin{array}{c}\text { Water } \\
\text { temperature, } \\
\text { in degrees } \\
\text { Celsius }\end{array}$ & $\begin{array}{c}\text { Dissolved } \\
\text { uranium, } \\
\text { in } \mathrm{mg} / \mathrm{L}\end{array}$ & $\begin{array}{c}\text { pH, } \\
\text { in units }\end{array}$ \\
\hline $724-4-93$ & 298 & 0.03 & 0.01 & 478 & 559 & 214 & 5.3 & 0.031 & 7.23 \\
\hline $724-5-98$ & 208 & 0.0039 & 0.0061 & 131 & 628 & 91.8 & 6.9 & 0.0195 & 7.49 \\
\hline $725-1-94$ & 243 & 0.06 & 0.01 & -164 & 514 & 207 & 8.4 & 0.009 & 7.33 \\
\hline $725-7-95$ & 232 & 0.07 & 0.01 & 269 & 607 & 220 & 9.2 & 0.006 & 7.44 \\
\hline $726-1-94$ & 74 & 0.01 & 0.01 & -476 & 391 & 159 & 9.2 & 0.00075 & 9.33 \\
\hline $726-2-97$ & 154 & 0.0093 & 0.0027 & -90 & 603 & 160 & 9.4 & 0.00075 & 9.56 \\
\hline $726-4-93$ & 91 & 0.01 & 0.01 & 244 & 508 & 162 & 10.6 & 0.00075 & 9.34 \\
\hline $726-5-98$ & 67 & 0.0088 & 0.0029 & -145 & 591 & 151 & 10 & 0.00075 & 9.25 \\
\hline $727-5-98$ & 150 & 0.0083 & 0.0035 & 6 & 678 & 146 & 12.5 & 0.00075 & 8.14 \\
\hline $728-1-94$ & 201 & 0.01 & 0.01 & 50 & 413 & 97 & 9.8 & 0.014 & 7.28 \\
\hline $728-2-97$ & 166 & 0.0044 & 0.0019 & 42 & 566 & 114 & 9.1 & 0.0103 & 7.59 \\
\hline $728-4-93$ & 215 & 0.01 & 0.01 & 466 & 373 & 106 & 7.8 & 0.015 & 7.48 \\
\hline $728-5-98$ & 170 & 0.00075 & 0.0018 & 113 & 553 & 91.3 & 9.6 & 0.0113 & 7.56 \\
\hline $729-10-04$ & 293 & 0.00075 & 0.0034 & 115 & 726 & 86 & 14.14 & 0.0073 & 7.18 \\
\hline $729-10-05$ & 291 & 0.005 & 0.0037 & 5 & 680 & 71.3 & 15.7 & 0.007 & 7.16 \\
\hline 729-11-06 & 390 & 0.0023 & 0.0031 & -110 & 771 & 83 & 14 & 0.01 & 7.16 \\
\hline 729-11-07 & 321 & 0.0037 & 0.0036 & 77.6 & 809 & 110 & 14.03 & 0.0094 & 7.1 \\
\hline 729-11-10 & 263 & 0.00423 & 0.00378 & 143.4 & 775 & 132 & 13.92 & 0.00599 & 7.17 \\
\hline 729-1-94 & 377 & 0.01 & 0.01 & -47 & 532 & 143 & 9 & 0.018 & 7.06 \\
\hline $729-6-11$ & 272 & 0.067 & 0.0035 & 198.2 & 710 & 100 & 10.55 & 0.0077 & 7.17 \\
\hline $730-10-04$ & 346 & 0.089 & 0.00075 & -145 & 1,037 & 190 & 13.43 & 0.0036 & 7.42 \\
\hline $730-10-05$ & 256 & 0.0822 & 0.003 & -177 & 966 & 188 & 14.42 & 0.0075 & 7.46 \\
\hline 730-11-06 & 408 & 0.064 & 0.0033 & -236 & 978 & 190 & 12.9 & 0.0066 & 7.48 \\
\hline $730-11-07$ & 370 & 0.057 & 0.0047 & -226 & 974 & 190 & 13.76 & 0.0042 & 7.41 \\
\hline $730-11-10$ & 336 & 0.0504 & 0.00547 & -35.6 & 1,063 & 174 & 13.44 & 0.00942 & 7.47 \\
\hline $730-1-94$ & 194 & 0.11 & 0.01 & -362 & 861 & 364 & 10.4 & 0.00075 & 7.66 \\
\hline $730-4-93$ & 148 & 0.04 & 0.01 & 418 & 811 & 400 & 10 & 0.00075 & 8.03 \\
\hline $730-5-04$ & 156 & 0.096 & 0.0029 & -150 & 1,033 & 300 & 11.4 & 0.00075 & 7.67 \\
\hline $730-6-05$ & 317 & 0.12 & 0.0011 & 74 & 797 & 170 & 14.65 & 0.0033 & 7.15 \\
\hline 730-6-06 & 211 & 0.077 & 0.0049 & -69.4 & 1,089 & 310 & 12.86 & 0.0014 & 7.87 \\
\hline $730-6-07$ & 352 & 0.057 & 0.0048 & -134 & 979 & 190 & 13.11 & 0.0067 & 7.43 \\
\hline 730-6-08 & 345 & 0.12 & 0.0045 & 20 & 982 & 190 & 11.51 & 0.0032 & 7.6 \\
\hline $730-6-11$ & 345 & 0.18 & 0.0047 & 164 & 957 & 160 & 11.06 & 0.0083 & 7.36 \\
\hline $732-5-99$ & 399 & 0.857 & 0.0592 & -97 & 3,940 & 2,040 & 9.3 & 0.011 & 7.08 \\
\hline $732-7-95$ & 344 & 0.68 & 0.1 & 309 & 2,810 & 3,000 & 13.2 & 0.016 & 7.11 \\
\hline $733-5-98$ & 193 & 0.0447 & 0.0053 & 139 & 868 & 185 & 13.3 & 0.0065 & 7.34 \\
\hline $733-7-95$ & 281 & 0.32 & 0.01 & 363 & 492 & 210 & 20 & 0.005 & 7.47 \\
\hline
\end{tabular}


Table 6. Water-quality data used in pattern-recognition analysis of Riverton, Wyoming, Uranium Mill Tailings Remedial Action (UMTRA) site.-Continued

[mg/L, milligram per liter; $\mathrm{mV}$, millivolt; $\mu \mathrm{S} / \mathrm{cm}$, microsiemens per centimeter $]$

\begin{tabular}{|c|c|c|c|c|c|c|c|c|c|}
\hline $\begin{array}{l}\text { Site number } \\
\text { and } \\
\text { collection date } \\
\text { (month-year) }\end{array}$ & $\begin{array}{c}\text { Total } \\
\text { alkalinity } \\
\text { as } \mathrm{CaCO}_{3^{\prime}} \\
\text { in } \mathrm{mg} / \mathrm{L}^{\prime}\end{array}$ & $\begin{array}{c}\text { Dissolved } \\
\text { manganese, } \\
\text { in mg/L }\end{array}$ & $\begin{array}{c}\text { Dissolved } \\
\text { molybdenum, } \\
\text { in } \mathrm{mg} / \mathrm{L}\end{array}$ & $\begin{array}{c}\text { Oxidation } \\
\text { reduction } \\
\text { potential, } \\
\text { in } \mathrm{mV}\end{array}$ & $\begin{array}{c}\text { Specific } \\
\text { conductance, } \\
\text { in } \mu \mathrm{S} / \mathrm{cm}\end{array}$ & $\begin{array}{l}\text { Dissolved } \\
\text { sulfate, } \\
\text { in } \mathrm{mg} / \mathrm{L}\end{array}$ & $\begin{array}{c}\text { Water } \\
\text { temperature, } \\
\text { in degrees } \\
\text { Celsius }\end{array}$ & $\begin{array}{c}\text { Dissolved } \\
\text { uranium, } \\
\text { in } \mathrm{mg} / \mathrm{L}\end{array}$ & $\begin{array}{c}\text { pH, } \\
\text { in units }\end{array}$ \\
\hline $735-10-04$ & 139 & 0.011 & 0.0021 & 152 & 1,625 & 630 & 12.19 & 0.00075 & 7.54 \\
\hline $735-10-05$ & 60 & 0.0216 & 0.0025 & 89 & 1,480 & 545 & 16.46 & 0.00075 & 7.73 \\
\hline $735-11-06$ & 161 & 0.11 & 0.0023 & 82 & 1,569 & 630 & 13.01 & 0.00075 & 7.69 \\
\hline $735-5-00$ & 126 & 0.12 & 0.0016 & -201 & 1,573 & 595 & 8.5 & 0.00075 & 7.95 \\
\hline $735-5-01$ & 178 & 0.122 & 0.00075 & 16 & 1,538 & 390 & 8.2 & 0.00075 & 7.94 \\
\hline $735-5-02$ & 137 & 0.0267 & 0.0018 & 146 & 1,427 & 552 & 8.35 & 0.00075 & 7.78 \\
\hline $735-5-03$ & 178 & 0.0091 & 0.0027 & 212 & 1,654 & 612 & 7.99 & 0.00075 & 7.62 \\
\hline $735-5-04$ & 144 & 0.015 & 0.0024 & 205 & 1,668 & 610 & 8.61 & 0.00075 & 9.21 \\
\hline $735-6-08$ & 156 & 0.022 & 0.0015 & 104 & 1,418 & 550 & 9.75 & 0.00075 & 7.7 \\
\hline $736-2-96$ & 199 & 0.13 & 0.01 & 118 & 852 & 368 & 9.2 & 0.005 & 7.53 \\
\hline 784-11-06 & 393 & 0.38 & 0.015 & 143 & 5,079 & 2,500 & 14.1 & 0.0065 & 7.9 \\
\hline 784-11-07 & 303 & 0.3 & 0.012 & -158 & 4,617 & 2,300 & 13.7 & 0.0056 & 7.97 \\
\hline 784-11-10 & 139 & 0.839 & 0.0144 & -45.5 & 4,859 & 2,180 & 15.07 & 0.0043 & 7.55 \\
\hline 784-6-06 & 453 & 0.31 & 0.016 & 67 & 4,863 & 2,100 & 13.88 & 0.0094 & 7.83 \\
\hline 784-6-07 & 333 & 0.52 & 0.012 & -23 & 4,790 & 2,200 & 13.24 & 0.0055 & 7.83 \\
\hline 784-6-08 & 242 & 0.54 & 0.023 & 6 & 4,983 & 2,400 & 11.72 & 0.0055 & 8.09 \\
\hline $784-6-11$ & 142 & 0.6 & 0.024 & 168.1 & 4,157 & 2,300 & 13.08 & 0.016 & 7.45 \\
\hline $788-10-04$ & 377 & 0.047 & 0.037 & 59 & 2,315 & 850 & 11.33 & 0.041 & 7.26 \\
\hline $788-10-05$ & 376 & 0.357 & 0.032 & 42 & 2,096 & 761 & 11.66 & 0.0372 & 7.4 \\
\hline $788-6-08$ & 404 & 0.015 & 0.02 & 48 & 2,228 & 880 & 9.38 & 0.034 & 7.38 \\
\hline $788-6-11$ & 475 & 0.38 & 0.025 & 207.3 & 4,797 & 2,500 & 9.98 & 0.091 & 7.1 \\
\hline 789-11-06 & 448 & 0.5 & 0.38 & 141.6 & 6,622 & 3,800 & 12.44 & 1.7 & 7.03 \\
\hline 789-11-07 & 425 & 0.34 & 0.5 & -61 & 6,210 & 3,800 & 11.12 & 1.4 & 7.01 \\
\hline 789-11-10 & 543 & 0.347 & 0.723 & 44.8 & 13,744 & 6,890 & 11.66 & 2.64 & 7.12 \\
\hline 789-6-07 & 419 & 0.82 & 0.4 & 121 & 6,351 & 3,500 & 9.47 & 1.6 & 6.99 \\
\hline 789-6-08 & 313 & 0.15 & 0.51 & 65 & 6,570 & 4,000 & 9.69 & 1.5 & 7.2 \\
\hline $789-6-11$ & 519 & 0.54 & 0.56 & 217.3 & 10,763 & 6,300 & 9.38 & 2.3 & 7.04 \\
\hline $824-11-07$ & 325 & 0.0048 & 0.0048 & 97 & 870 & 130 & 10.69 & 0.016 & 7.2 \\
\hline 824-11-10 & 342 & 0.00534 & 0.00503 & 56.9 & 1,013 & 169 & 12.89 & 0.0178 & 7.21 \\
\hline $824-6-07$ & 279 & 0.0069 & 0.0037 & 55 & 758 & 110 & 9.45 & 0.015 & 7.26 \\
\hline 824-6-08 & 340 & 0.007 & 0.0041 & 88 & 862 & 140 & 9.45 & 0.02 & 7.31 \\
\hline $824-6-11$ & 207 & 0.0083 & 0.0064 & 161 & 568 & 65 & 13.91 & 0.0086 & 7.31 \\
\hline $826-11-07$ & 335 & 0.45 & 0.026 & -66 & 1,422 & 430 & 10.3 & 0.029 & 7.32 \\
\hline $826-11-10$ & 472 & 2.47 & 0.0468 & 30.3 & 4,519 & 1,820 & 11.5 & 0.0784 & 7.13 \\
\hline $826-6-07$ & 346 & 0.51 & 0.022 & -65 & 1,408 & 380 & 9 & 0.026 & 7.35 \\
\hline $826-6-08$ & 349 & 0.53 & 0.022 & -0.3 & 1,298 & 340 & 8.97 & 0.029 & 7.48 \\
\hline $826-6-11$ & 446 & 2.2 & 0.031 & 194.1 & 3,247 & 1,400 & 9.97 & 0.058 & 7.09 \\
\hline
\end{tabular}


Table 6. Water-quality data used in pattern-recognition analysis of Riverton, Wyoming, Uranium Mill Tailings Remedial Action (UMTRA) site.-Continued

[mg/L, milligram per liter; $\mathrm{mV}$, millivolt; $\mu \mathrm{S} / \mathrm{cm}$, microsiemens per centimeter]

\begin{tabular}{|c|c|c|c|c|c|c|c|c|c|}
\hline $\begin{array}{l}\text { Site number } \\
\text { and } \\
\text { collection date } \\
\text { (month-year) }\end{array}$ & $\begin{array}{c}\text { Total } \\
\text { alkalinity } \\
\text { as } \mathrm{CaCO}_{3^{\prime}} \\
\text { in } \mathrm{mg} / \mathrm{L}\end{array}$ & $\begin{array}{c}\text { Dissolved } \\
\text { manganese, } \\
\text { in } \mathrm{mg} / \mathrm{L}\end{array}$ & $\begin{array}{c}\text { Dissolved } \\
\text { molybdenum, } \\
\text { in } \mathrm{mg} / \mathrm{L}\end{array}$ & $\begin{array}{c}\text { Oxidation } \\
\text { reduction } \\
\text { potential, } \\
\text { in } \mathrm{mV}\end{array}$ & $\begin{array}{c}\text { Specific } \\
\text { conductance, } \\
\text { in } \mu \mathrm{S} / \mathrm{cm}\end{array}$ & $\begin{array}{l}\text { Dissolved } \\
\text { sulfate, } \\
\text { in } \mathrm{mg} / \mathrm{L}\end{array}$ & $\begin{array}{c}\text { Water } \\
\text { temperature, } \\
\text { in degrees } \\
\text { Celsius }\end{array}$ & $\begin{array}{c}\text { Dissolved } \\
\text { uranium, } \\
\text { in } \mathrm{mg} / \mathrm{L}\end{array}$ & $\begin{array}{c}\text { pH, } \\
\text { in units }\end{array}$ \\
\hline $828-10-05$ & 146 & 0.0049 & 0.0041 & 116.8 & 817 & 215 & 15.69 & 0.00075 & 8.83 \\
\hline $828-11-06$ & 147 & 0.006 & 0.0038 & 154 & 858 & 240 & 12.4 & 0.00075 & 8.83 \\
\hline $828-11-07$ & 168 & 0.0088 & 0.0038 & 15 & 833 & 240 & 11.07 & 0.00075 & 8.8 \\
\hline $828-6-07$ & 152 & 0.0074 & 0.0036 & 65 & 848 & 220 & 15.83 & 0.00075 & 8.69 \\
\hline 828-6-08 & 164 & 0.0044 & 0.0038 & 68 & 840 & 230 & 13.98 & 0.00075 & 8.88 \\
\hline $828-6-11$ & 182 & 0.0013 & 0.0031 & 215.8 & 795 & 210 & 14.65 & 0.00075 & 8.75 \\
\hline $951-10-05$ & 102 & 0.0062 & 0.0024 & 43 & 847 & 259 & 12.56 & 0.00075 & 8.83 \\
\hline $951-11-06$ & 111 & 0.0059 & 0.0022 & 160 & 860 & 290 & 14.5 & 0.00075 & 8.84 \\
\hline 747SW-7-97 & 120 & 0.88 & 0.0155 & 142 & 1,747 & 656 & 27.1 & 0.217 & 8.23 \\
\hline 796SW-5-98 & 107 & 0.0516 & 0.0337 & 169 & 463 & 1,270 & 24.6 & 0.0017 & 8.34 \\
\hline 794SW-5-98 & 95 & 0.0051 & 0.00075 & 111 & 454 & 109 & 10.5 & 0.0017 & 7.3 \\
\hline 749SW-5-98 & 401 & 0.0052 & 0.00075 & 111 & 3,590 & 109 & 10.4 & 0.00075 & 8.18 \\
\hline 747SW-5-98 & 222 & 0.855 & 0.0228 & 64 & 2,220 & 824 & 15.5 & 0.408 & 8.57 \\
\hline 796SW-05-99 & 160 & 0.0139 & 0.002 & 166 & 780 & 227 & 8.1 & 0.0054 & 8.14 \\
\hline 794SW-05-99 & 148 & 0.0105 & 0.002 & 207 & 794 & 232 & 7.6 & 0.0058 & 8.15 \\
\hline 749SW-05-99 & 192 & 1.13 & 0.025 & 209 & 980 & 249 & 8.2 & 0.151 & 8.6 \\
\hline 747SW-05-99 & 218 & 0.0083 & 0.008 & 207 & 1,628 & 591 & 15.4 & 0.00075 & 7.36 \\
\hline 747SW-05-00 & 272 & 1.78 & 0.0277 & 175 & 442 & 111 & 12.1 & 0.0029 & 7.77 \\
\hline 796SW-05-00 & 92 & 0.0139 & 0.0012 & 140 & 3,680 & 1,920 & 14.9 & 0.662 & 8.3 \\
\hline 796SW-05-02 & 148 & 0.0326 & 0.0035 & -47 & 1,106 & 1,670 & 19.87 & 0.00075 & 7.3 \\
\hline 749SW-05-02 & 916 & 0.039 & 0.0018 & 80 & 4,436 & 421 & 19.5 & 0.0088 & 8.54 \\
\hline 794SW-05-03 & 187 & 0.0211 & 0.002 & 203.7 & 981 & 363 & 18.18 & 0.0077 & 8.64 \\
\hline 796SW-05-03 & 153 & 0.0257 & 0.002 & 211 & 667 & 375 & 18.43 & 0.0072 & 8.7 \\
\hline 747SW-05-03 & 266 & 0.528 & 0.0195 & 98 & 1,657 & 668 & 12.73 & 0.321 & 7.55 \\
\hline 749SW-05-03 & 139 & 0.0273 & 0.0022 & 174 & 585 & 226 & 15.33 & 0.00075 & 8.84 \\
\hline 810SW-05-04 & 293 & 0.032 & 0.0048 & 144 & 3,734 & 290 & 24.6 & 0.0033 & 9.02 \\
\hline 822SW-05-04 & 344 & 0.038 & 0.0018 & 202 & 1,116 & 1,500 & 20.5 & 0.0076 & 7.87 \\
\hline 811SW-05-04 & 91 & 0.014 & 0.00075 & 213 & 406 & 97 & 20.1 & 0.0025 & 8.41 \\
\hline 794SW-05-04 & 101 & 0.021 & 0.00075 & 187 & 410 & 98 & 19.7 & 0.0022 & 8.46 \\
\hline 796SW-05-04 & 84 & 0.012 & 0.00075 & 73 & 1,442 & 2,300 & 24.7 & 0.0019 & 8.33 \\
\hline 749SW-05-04 & 451 & 0.01 & 0.00075 & 41 & 326 & 83 & 14.3 & 0.00075 & 7.13 \\
\hline 812SW-05-04 & 84 & 0.014 & 0.0073 & 41 & 366 & 84 & 16.9 & 0.42 & 6.91 \\
\hline 747SW-05-04 & 352 & 2.1 & 0.032 & 70 & 5,320 & 670 & 17.8 & 0.0022 & 8.28 \\
\hline 796SW-10-04 & 140 & 0.0079 & 0.0028 & 121 & 805 & 190 & 5.4 & 0.0065 & 7.27 \\
\hline 822SW-10-04 & 430 & 0.0019 & 0.0034 & 179 & 641 & 1,200 & 10.72 & 0.0034 & 8.25 \\
\hline 794SW-10-04 & 137 & 0.008 & 0.00075 & 114 & 634 & 180 & 11.32 & 0.0073 & 8.29 \\
\hline 823SW-10-04 & 117 & 0.048 & 0.0011 & 142 & 1,606 & 560 & 10.07 & 0.0041 & 8.41 \\
\hline
\end{tabular}


Table 6. Water-quality data used in pattern-recognition analysis of Riverton, Wyoming, Uranium Mill Tailings Remedial Action (UMTRA) site.-Continued

[mg/L, milligram per liter; $\mathrm{mV}$, millivolt; $\mu \mathrm{S} / \mathrm{cm}$, microsiemens per centimeter $]$

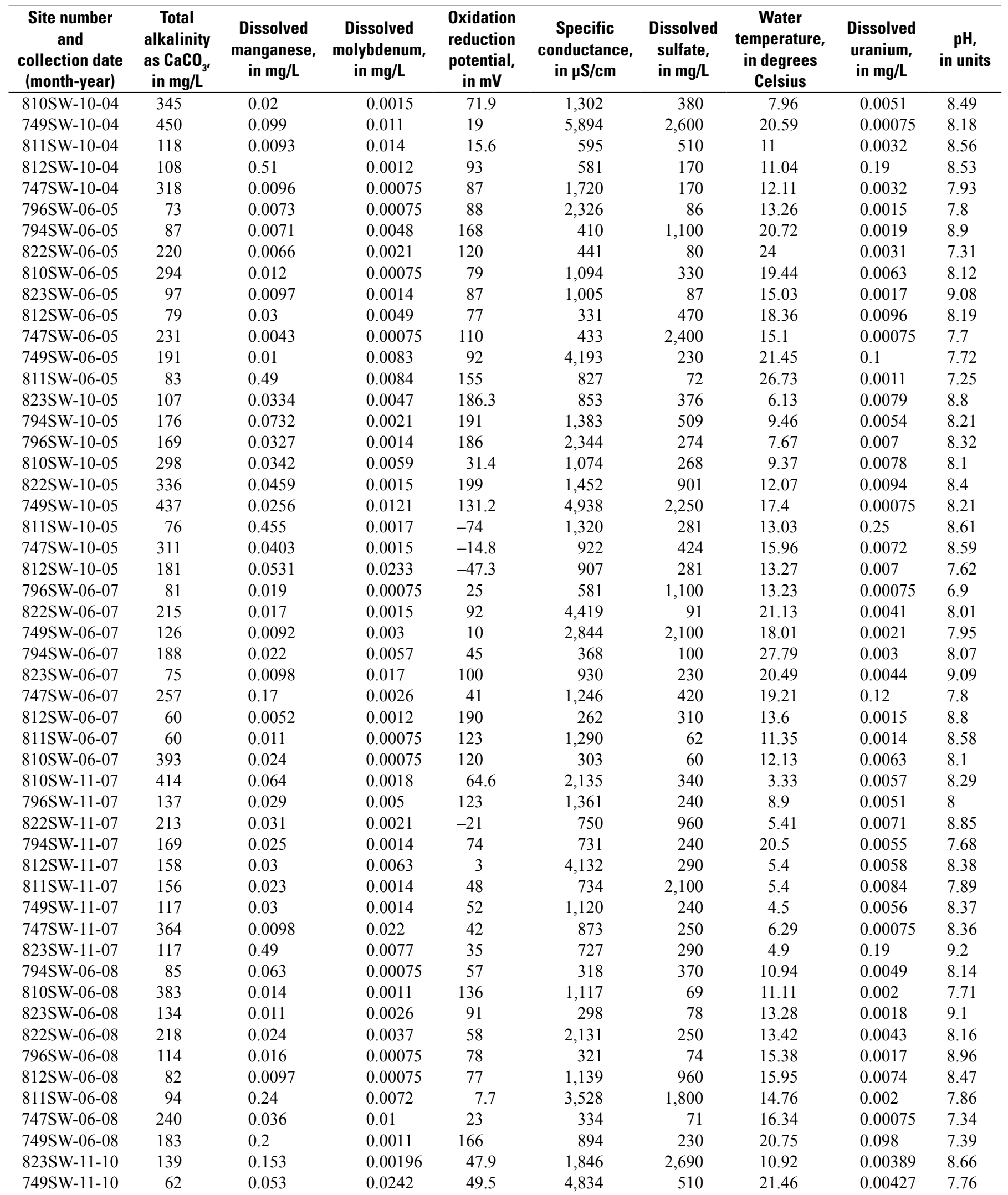




\section{Assessment of Groundwater and Little Wind River, Wind River Reservation, Wyoming, 1987-2010}

Table 6. Water-quality data used in pattern-recognition analysis of Riverton, Wyoming, Uranium Mill Tailings Remedial Action (UMTRA) site.-Continued

[mg/L, milligram per liter; $\mathrm{mV}$, millivolt; $\mu \mathrm{S} / \mathrm{cm}$, microsiemens per centimeter]

\begin{tabular}{|c|c|c|c|c|c|c|c|c|c|}
\hline $\begin{array}{c}\text { Site number } \\
\text { and } \\
\text { collection date } \\
\text { (month-year) }\end{array}$ & $\begin{array}{c}\text { Total } \\
\text { alkalinity } \\
\text { as } \mathrm{CaCO}_{3^{\prime}} \\
\text { in } \mathrm{mg} / \mathrm{L}\end{array}$ & $\begin{array}{c}\text { Dissolved } \\
\text { manganese, } \\
\text { in } \mathrm{mg} / \mathrm{L}\end{array}$ & $\begin{array}{c}\text { Dissolved } \\
\text { molybdenum, } \\
\text { in } \mathrm{mg} / \mathrm{L}\end{array}$ & $\begin{array}{c}\text { Oxidation } \\
\text { reduction } \\
\text { potential, } \\
\text { in } \mathrm{mV}\end{array}$ & $\begin{array}{c}\text { Specific } \\
\text { conductance, } \\
\text { in } \mu S / \mathrm{cm}\end{array}$ & $\begin{array}{l}\text { Dissolved } \\
\text { sulfate, } \\
\text { in } \mathrm{mg} / \mathrm{L}\end{array}$ & $\begin{array}{c}\text { Water } \\
\text { temperature, } \\
\text { in degrees } \\
\text { Celsius }\end{array}$ & $\begin{array}{c}\text { Dissolved } \\
\text { uranium, } \\
\text { in } \mathrm{mg} / \mathrm{L}\end{array}$ & $\begin{array}{c}\mathrm{pH}, \\
\text { in units }\end{array}$ \\
\hline $811 \mathrm{SW}-11-10$ & 208 & 0.0426 & 0.00196 & 109 & 2,594 & 308 & 8.63 & 0.543 & 7.87 \\
\hline 822SW-11-10 & 197 & 0.0405 & 0.0251 & 113.3 & 4,868 & 307 & 9.86 & 0.00826 & 8.1 \\
\hline $747 \mathrm{SW}-11-10$ & 377 & 0.0351 & 0.00168 & 68.2 & 1,060 & 2,080 & 10.86 & 0.00831 & 8.41 \\
\hline 796SW-11-10 & 190 & 0.0448 & 0.00272 & 97.4 & 1,139 & 329 & 9.09 & 0.00765 & 8.43 \\
\hline 794SW-06-11 & 117 & 0.051 & 0.0041 & 231.9 & 3,344 & 59 & 11.94 & 0.0018 & 8.82 \\
\hline 810SW-06-11 & 396 & 0.0037 & 0.009 & 185.3 & 251 & 980 & 24.8 & 0.0024 & 8.44 \\
\hline 749SW-06-11 & 95 & 0.054 & 0.0015 & 177.2 & 1,819 & 330 & 13.16 & 0.0014 & 8.17 \\
\hline 796SW-06-11 & 98 & 0.0067 & 0.003 & 222.3 & 2,052 & 650 & 19.35 & 0.0054 & 7.74 \\
\hline 812SW-06-11 & 65 & 0.0067 & 0.0026 & 167.5 & 430 & 56 & 19.38 & 0.028 & 7.98 \\
\hline 823SW-11-11 & 109 & 0.033 & 0.0016 & 27.8 & 958 & 290 & 3.16 & 0.0062 & 6.96 \\
\hline 796SW-11-11 & 187 & 0.046 & 0.0013 & 174.1 & 3,267 & 1,800 & 1 & 0.0045 & 8.33 \\
\hline 749SW-11-11 & 21 & 0.042 & 0.0014 & 271.9 & 2,408 & 290 & 0.72 & 0.0013 & 7.77 \\
\hline 794SW-11-11 & 177 & 0.041 & 0.0088 & 223.1 & 919 & 920 & 16.6 & 0.0069 & 8.26 \\
\hline 811SW-11-11 & 182 & 0.035 & 0.0016 & 96.6 & 899 & 290 & 1.48 & 0.23 & 7.84 \\
\hline 747SW-11-11 & 296 & 0.62 & 0.0054 & 32.9 & 2,363 & 900 & 4.74 & 0.0097 & 7.54 \\
\hline 822SW-11-11 & 204 & 0.099 & 0.013 & 80.9 & 1,963 & 1,000 & 2.14 & 0.0066 & 8.58 \\
\hline 810SW-11-11 & 461 & 0.072 & 0.0013 & 31.3 & 1,755 & 300 & 1.9 & 0.0097 & 8.5 \\
\hline 812SW-11-11 & 186 & 0.34 & 0.0019 & -34.9 & 947 & 450 & 2.79 & 0.0067 & 8.55 \\
\hline
\end{tabular}



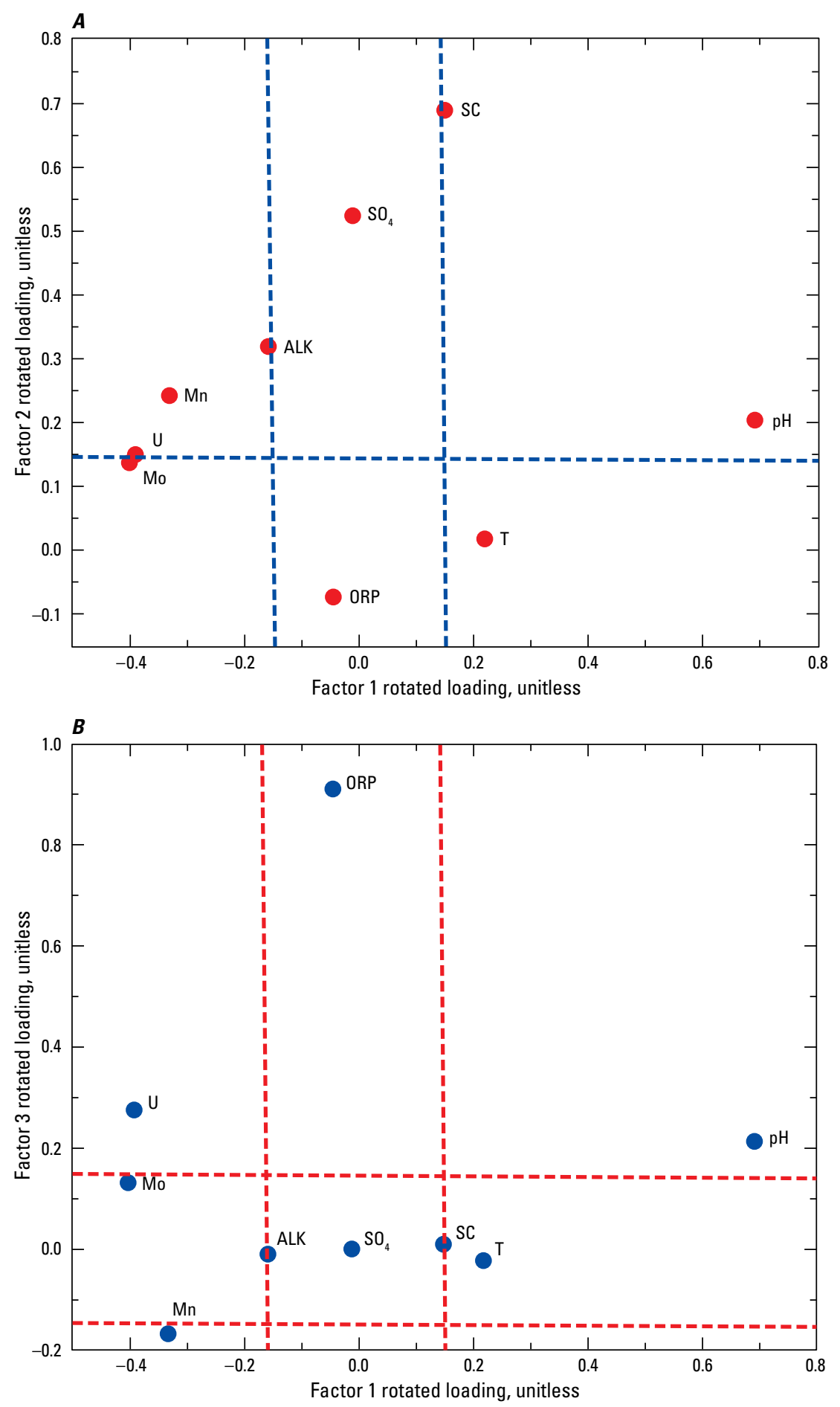

Figure 32. Loading values and associated chemical constituent for principalcomponents-analysis $A$, factors 1 and 2 and $B$, factors 1 and 3 , Riverton, Wyoming, Uranium Mill Tailings Remedial Action Project monitoring data. SC, specific conductance; ALK, alkanity; T, water tempetature; ORP, oxidation reduction potential. 

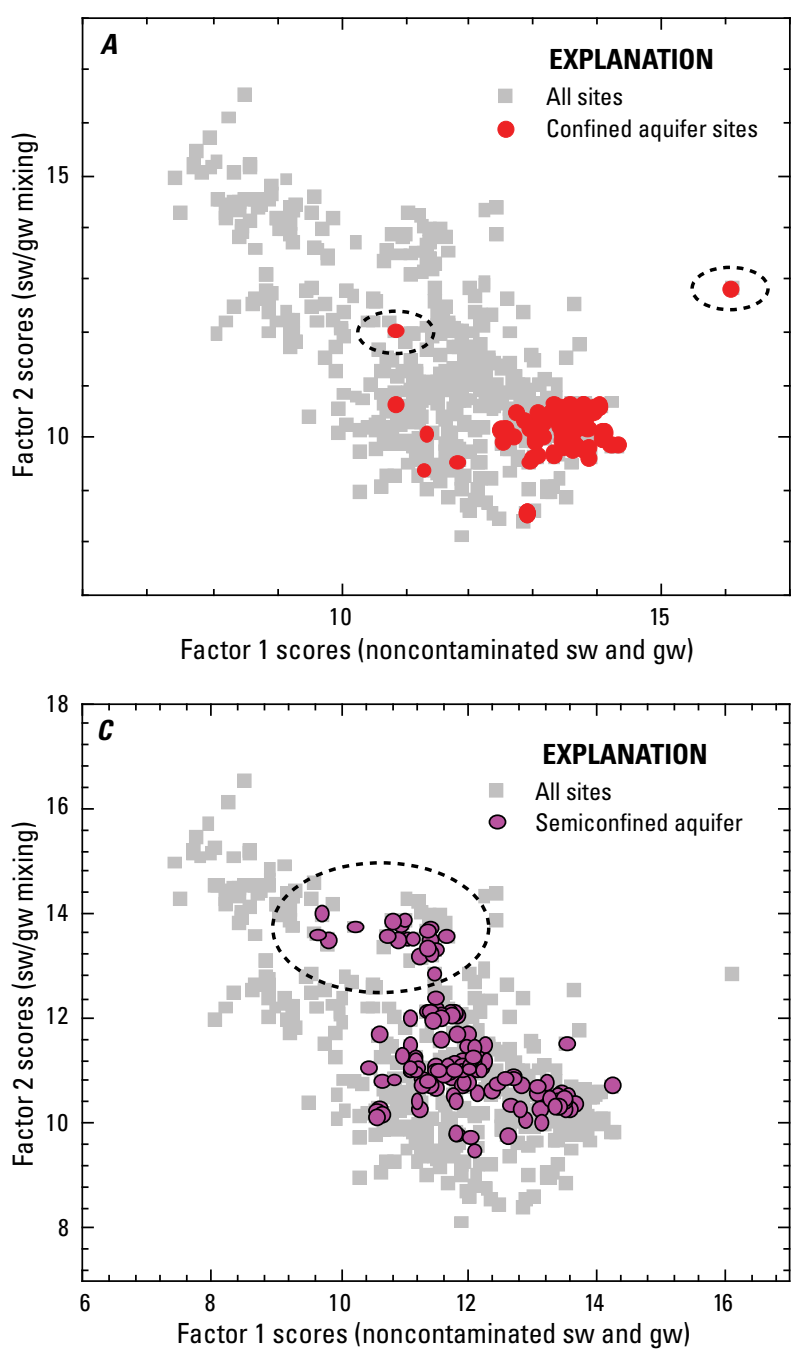

and 709 during May 1998 and January 1997, respectively. This was the only time that these wells were sampled.

About 50 percent of the water samples collected from the unconfined aquifer contain low factor 1 scores and high factor 2 scores (fig. 33B) indicating that this aquifer contains contaminated water. Figure 34 shows the location of wells completed in the unconfined aquifer that contain factor 2 scores greater than 12 and factor 1 scores less than 10. The seven wells shown on the map include wells $707,716,718$, $722 \mathrm{R}, 788,789$, and 826 and are all located downgradient from the reclaimed mill site.

The factor scores associated with the majority of water samples collected from the semiconfined aquifer do not indicate any influence of contamination (high factor 1 scores and low factor 2 scores) (fig. $33 \mathrm{C}$ ). A subgrouping of samples collected from the semiconfined aquifer has elevated (greater than 12.5) factor 2 scores indicating some influence from contaminant sources. The majority (19 out of 21) of water samples from the semiconfined aquifer with elevated factor 2 scores were limited to monitoring well 723, and the other two samples were collected from monitoring well 732. Well 723 is in the same location as well $722 \mathrm{R}$, which

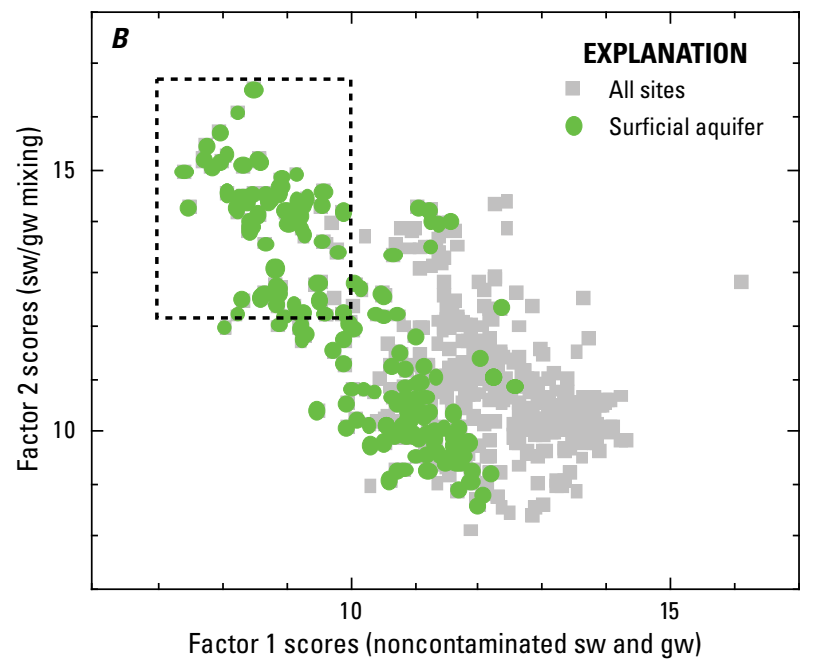

Figure 33. Scatter plots comparing factor 1 and factor 2 scores determined by principal-components analysis of 529 water samples collected from the Riverton, Wyoming, Uranium Mill Tailings Remedial Action site from April 1993 through November 2011. Factor scores are differentiated by aquifer. $A$, Confined aquifer samples; $B$, unconfined aquifer samples; and $C$, semiconfined aquifer samples. Dashed lines outline samples that likely have a geochemical signature associated with contamination. sw, surface water; gw, groundwater.

was completed in the unconfined aquifer and contained a large number of water samples with elevated factor 2 scores (figs. 34 and 35).

Temporal trends of factor 1 and 2 scores associated with water samples collected in the unconfined aquifer were used to identify monitoring periods when conditions in the unconfined aquifer may have reflected consistently less contaminated conditions (high factor 1 and low factor 2 scores) or more contaminated conditions (low factor 1 scores and high factor 2 scores) (fig. 36). During the monitoring period from mid-2004 through mid-2008 (calendar year), numerous samples from the unconfined aquifer displayed high factor 1 scores and low factor 2 scores (fig. 36) indicative of "less contaminated" conditions. The groundwater samples displaying these trends from 2004 through 2008 were collected from four monitoring wells $(716,722 \mathrm{R}, 788$, and 826). The locations of these four wells are not in close proximity to each other with locations ranging from an upgradient well (716) within the historic mill tailings boundary to a downgradient well (788) near the Little Wind River (fig. 34).

The changes in water elevations measured in the four monitoring wells (fig. 37A) were compared with the annual 


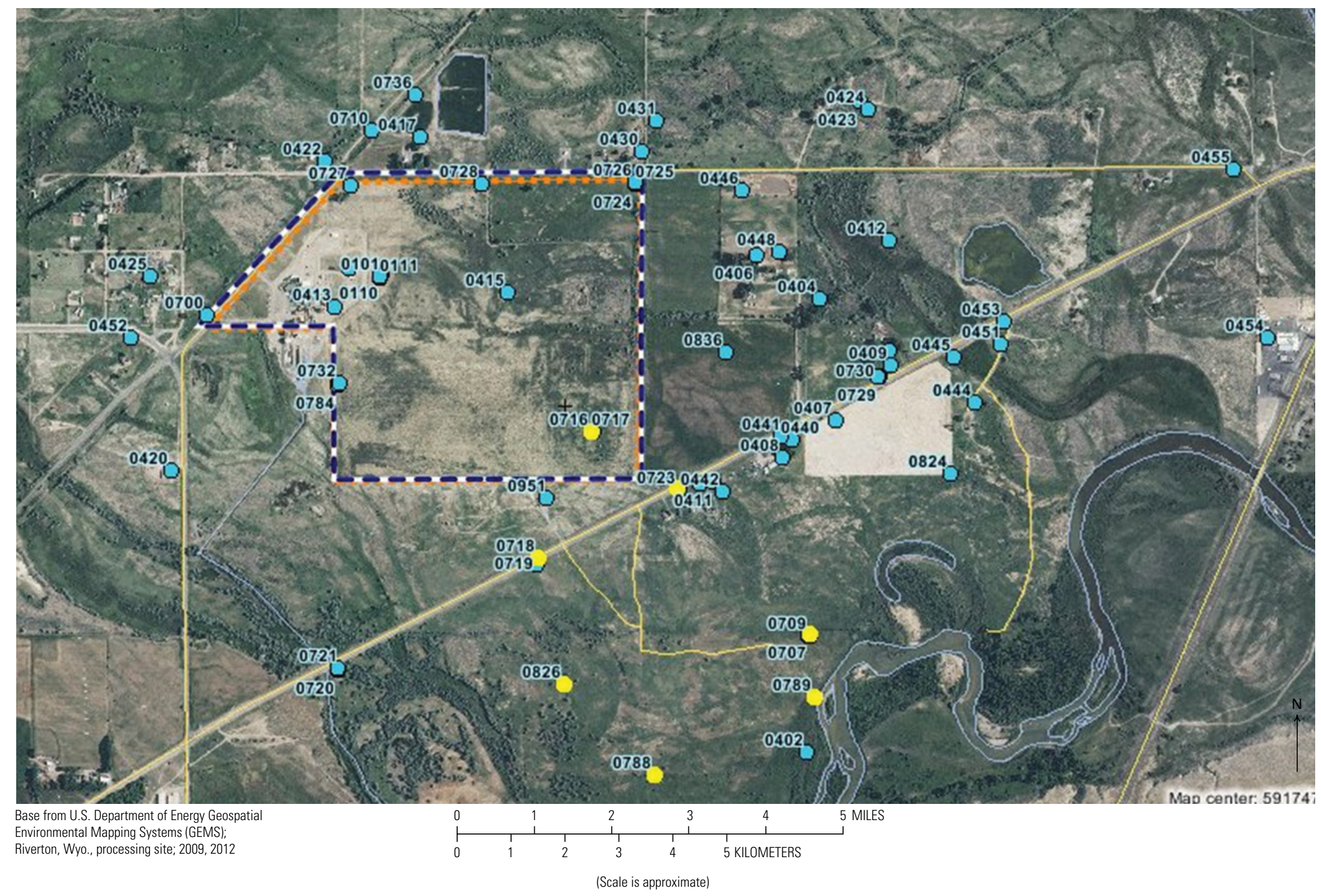

Figure 34. Location of wells completed in the unconfined aquifer with factor 1 scores less than 10 (blue) and factor 2 scores greater than 12 (yellow), Riverton, Wyoming, Uranium Mill Tailings Remedial Action site. 


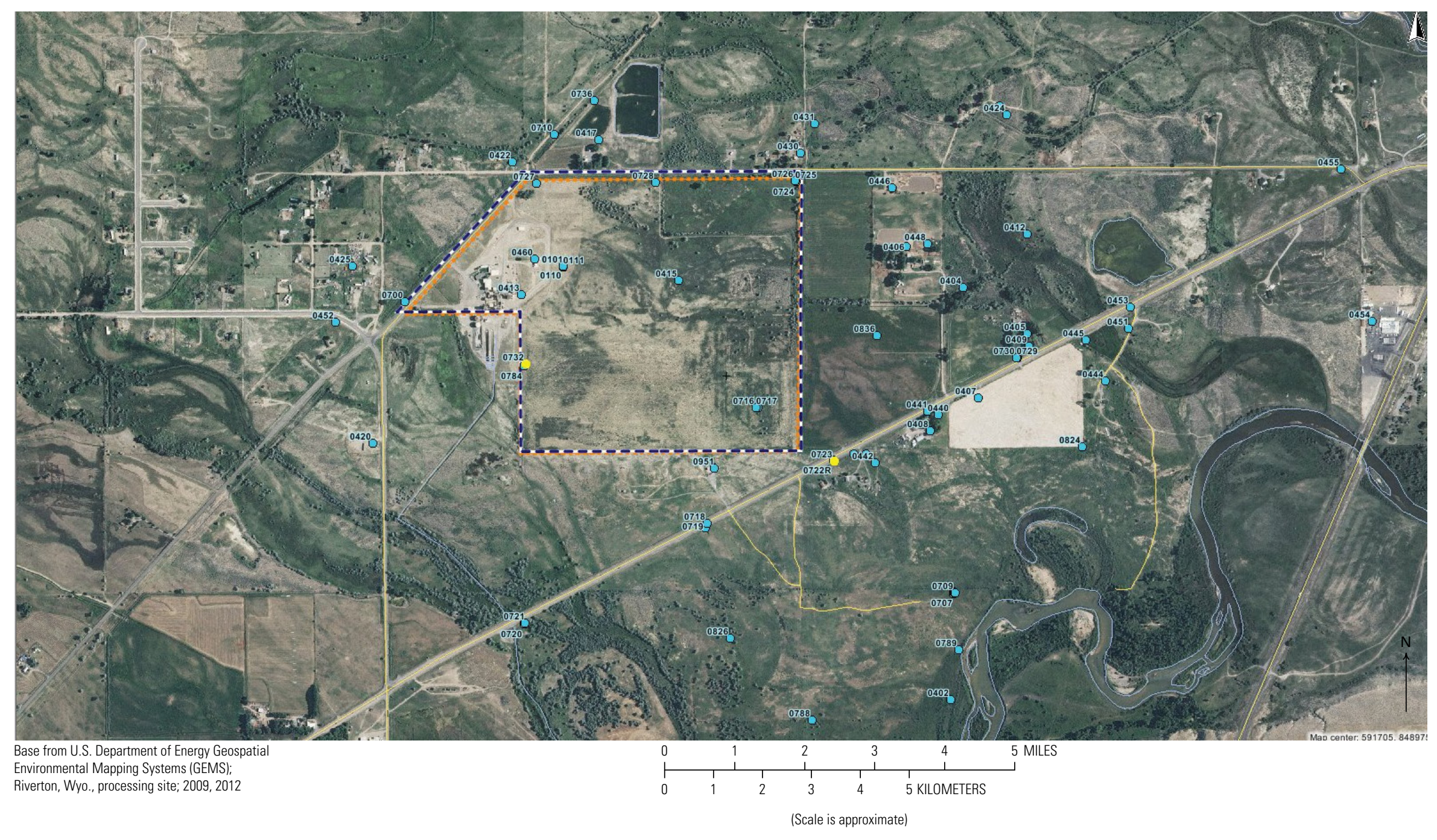

Figure 35. Location of wells completed in the semiconfined aquifer with factor 2 scores greater than 12.5 (yellow), Riverton Wyoming, Uranium Mill Tailings Remedial Action site. 


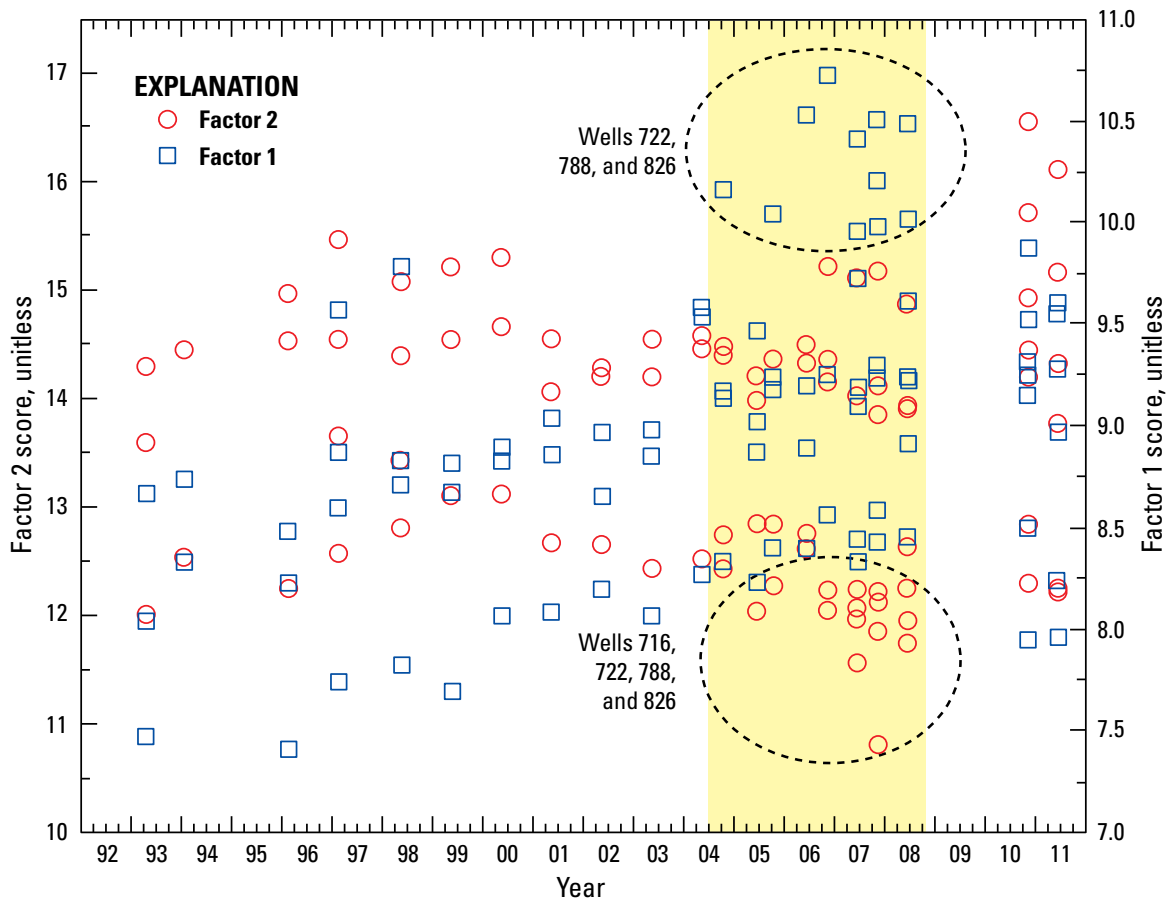

Figure 36. Scatter plots showing temporal trends in factor 1 and factor 2 scores for water samples collected from the unconfined aquifer from 1993 through 2011, Riverton, Wyoming, Uranium Mill Tailings Remedial Action site.
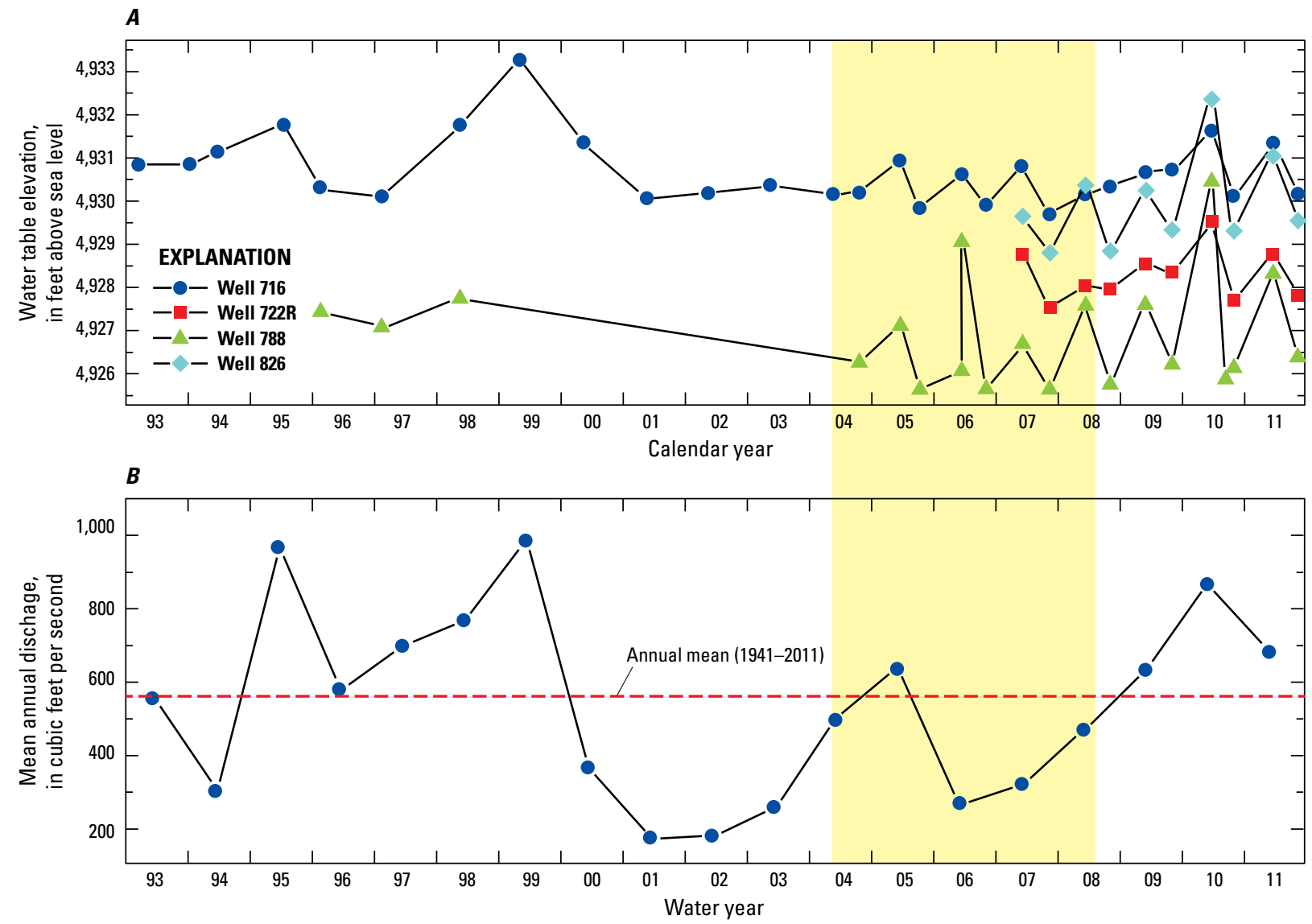

Figure 37. $A$, Water elevation in selected wells completed in the unconfined aquifer compared to $B$, annual mean (1993-2011) and mean annual discharge (1941-2011) in the Little Wind River near Riverton, Wyoming, streamgage (USGS 06235500). 
mean discharge in the Little Wind River from water years 1993 through 2011 and the mean annual discharge for 19412011 (U.S. Geological Survey, 2013) (fig. 37B). The time scale used for this comparison is slightly offset because the waterelevation data are plotted by the date of measurement, and the annual mean discharge data are plotted by water year. With the exception of water year 2005, the annual mean discharge in the Little Wind River was below the mean annual discharge (1941 to 2011) during the period of anomalous factor 1 and 2 scores (2004-2008). Water levels in the four wells of interest during this same time period displayed relatively stable elevations over an annual cycle combined with small seasonal increases during spring water-elevation measurements. Unfortunately, there is a 2-year data gap from mid-2008 to mid-2010 (fig. 36); however, water samples collected during 2010 and 2011 do not display the clustering of low factor 2 scores and high factor 1 scores displayed in water samples collected from mid-2004 through mid-2008.

The disappearance of distinct clustering of low factor 2 and high factor 1 scores is likely due to the increasing water elevations beginning in mid-2008 and continuing through mid2010. Increasing groundwater elevations beginning in 2008 were likely driven by the higher annual discharge in the Little Wind River during water years 2009 and 2010 (fig. 37B). The increasing water elevations in the unconfined aquifer likely resaturated previously dry aquifer material. This resaturation process likely dissolved or desorbed contaminants that were deposited during previous high-water levels in the 1990s, which would be consistent with decreasing the factor 1 scores associated with noncontaminated groundwater and increasing factor 2 scores associated with contaminated groundwater.

Figure 38 compares the factor 1 and 2 scores for surfacewater samples collected from the Riverton UMTRA site from April 1993 through November 2011. The factor 1 and 2 scores for the majority of surface-water samples plot in the same region of noncontaminated groundwater samples from the three different aquifers in the study area discussed previously (fig. 33). Eight surface-water samples contain a combination of either an elevated factor 2 score or a relatively low factor 1 score combined with an elevated factor 2 score and were classified with a contamination signature (fig. 38).

All of the surface-water samples considered to have a contamination signature were associated with three surfacewater sampling sites $(747,749$, and 796). Sample site 796 is on the main channel of the Little Wind River (fig. 39) and only has one sample with a contamination signature. It is likely that this one occurrence is an anomaly and does not represent a contamination issue in the main channel of the Little Wind River. In contrast, multiple samples from surface-water sample sites 747 and 749 have a contamination signature (fig. 38).

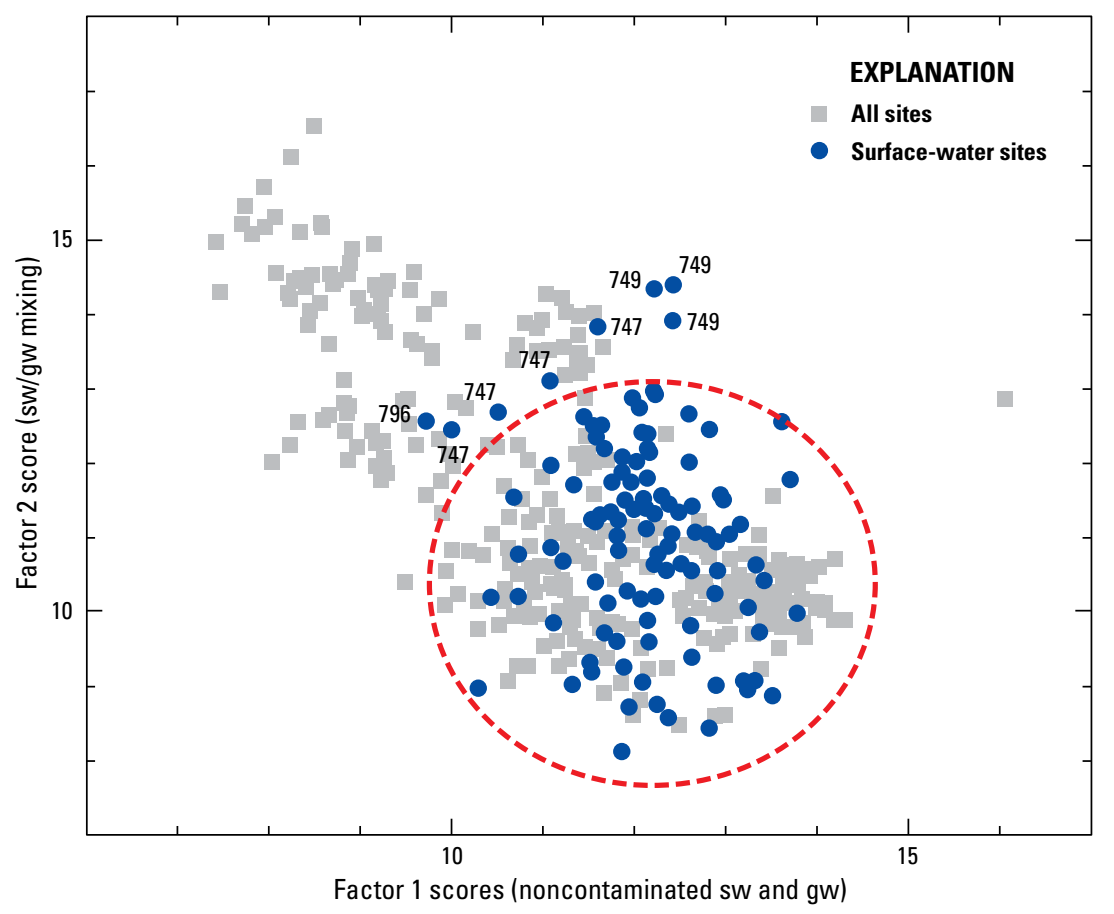

Figure 38. Scatter plots comparing factor 1 and factor 2 scores determined by principal components analysis for 116 surface-water samples collected from the Riverton, Wyoming, Uranium Mill Tailings Remedial Action site from April 1993 through November 2011. Samples falling inside the dashed line are likely not associated with contamination. Number adjacent to each symbol designates the surface-water sample site. sw, surface water; gw, groundwater. 


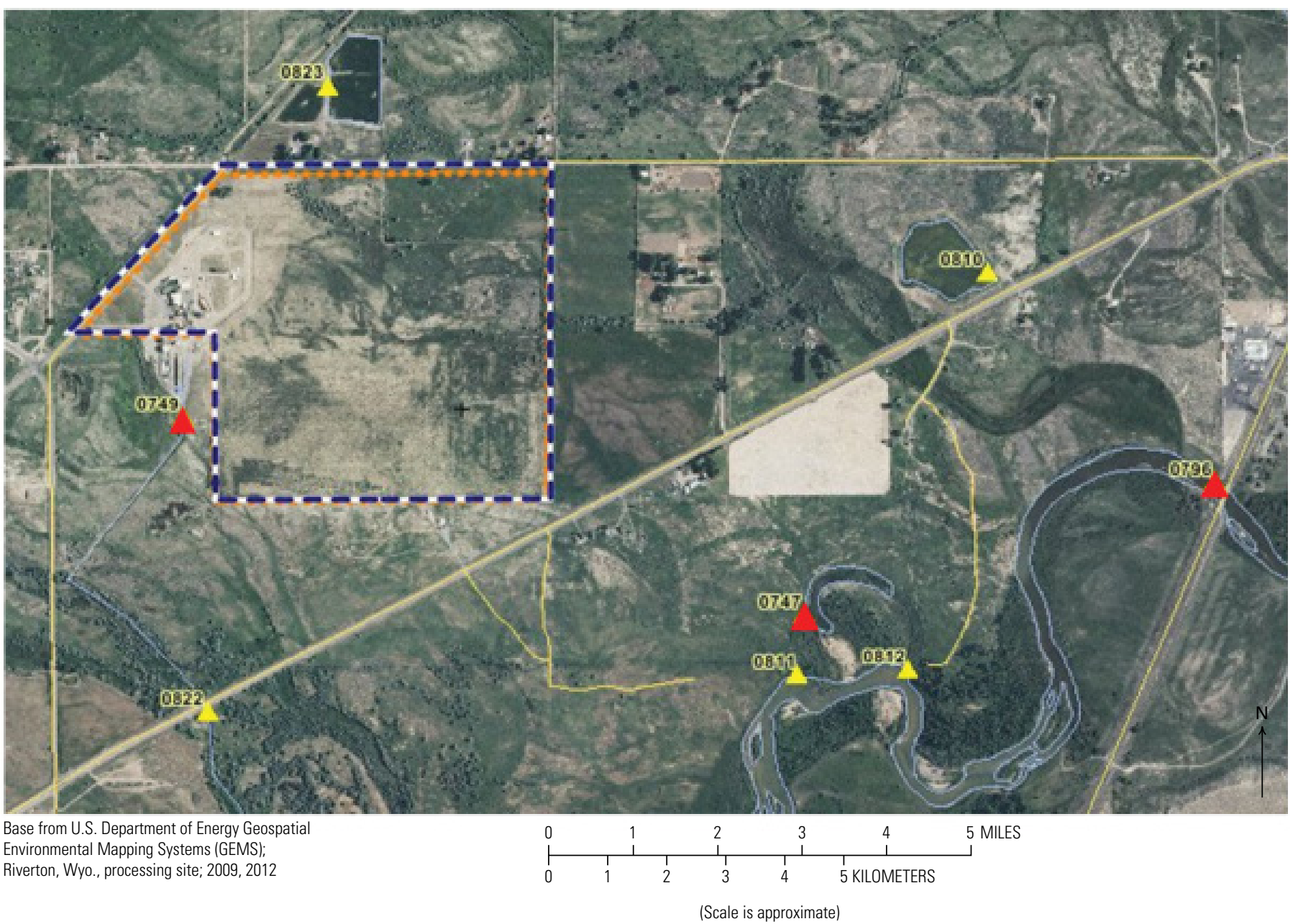

Figure 39. Location of surface-water monitoring sites at the Riverton, Wyoming, Uranium Mill Tailings Remedial Action site. Red triangle indicates an elevated factor 2 score. Yellow triangle indicates a low or non-elevated factor 2 score.

Surface-water site 747 is located at Oxbow Lake (fig. 39) and has factor 1 and 2 scores that are similar to the contaminated samples associated with the unconfined and semiconfined aquifers (fig. 33). As noted in the Site Observational Work Plan (U.S. Department of Energy, 1998, p. 4-11), groundwater from the unconfined and semiconfined aquifers are likely recharge sources to Oxbow Lake, which has been isolated from the Little Wind River during the monitoring period. The third surface-water location with multiple samples indicating a contaminant signature is site 749 (fig. 38). Site 749 is located directly in the drainage ditch immediately downstream from the sulfuric-acid plant.

This statistical analysis supports the hypotheses described in previous sections, which are the following: (1) there is no evidence of contamination in the lower confined bedrock aquifer, (2) there is evidence of contamination in the intermediate semiconfined bedrock aquifer at a few locations, mainly at DOE wells 723 and 732, (3) contaminated groundwater is discharging into Oxbow Lake, and (4) the increased concentrations of COCs measured in several DOE wells following the flooding of the Little Wind River in June 2010 most likely are a result of the increase in the groundwater table dissolving or desorbing contaminants that were deposited in the upper soil layers during previous high-water elevations in the 1990s. The analyses described in previous sections indicated that other DOE wells screened in the intermediate semiconfined bedrock aquifer also had evidence of contamination. These were DOE wells 111 (on the basis of high concentrations of manganese) and 705, 717, 719 , and 735 (on the basis of high concentrations of sulfate only). Why the PCA did not identify these wells as being contaminated is not known; perhaps the high concentration of sulfate in these wells is from natural sources. 


\section{Effectiveness of Natural Attenuation of the Contaminants of Concern}

The effectiveness of natural attenuation for the COCs was evaluated by determining (1) the spatial distribution of the concentration of the COCs in the upper unconfined alluvial aquifer throughout the UMTRA site, (2) how the mobility of the COCs in the upper unconfined alluvial aquifer throughout the UMTRA site may be affected by temporal and spatial changes in groundwater chemistry, and (3) temporal variation of the COCs between the upper unconfined alluvial aquifer and the intermediate semiconfined bedrock aquifer, where possible. Potential temporal and spatial changes in the mobility of arsenic, manganese, molybdenum, sulfate, and uranium in the upper unconfined alluvial aquifer was done by using PHREEQC to determine the complexes and the saturation indices with respect to commonly occurring solid phases for each of the above mentioned COCs in nested wells within the groundwater plume. Although there is some overlap with the analysis in this section and that presented in the "Extent of Contaminated Groundwater Among the Three Aquifers" section, the analysis in this section will give the reader a clearer understanding of spatial and temporal variations in the COCs in the upper unconfined alluvial and the intermediate semiconfined bedrock aquifers.

The distribution of the concentration of arsenic, manganese, molybdenum, nickel, sulfate, and uranium throughout the UMTRA site in the upper unconfined alluvial aquifer and in the Little Wind River is shown in figures 40 and 41. Median concentrations of arsenic only are plotted because it was not possible to construct boxplots for arsenic due to the large number of values reported below the detection limit. To further evaluate the east-west extent of the contaminated groundwater plume in the upper unconfined alluvial aquifer and in the intermediate semiconfined aquifer, and changes over time, time-series plots of the concentrations of manganese, molybdenum, sulfate, and uranium in five sets of nested DOE wells on an east-west axis along route 137 were compared (fig. 42). The sampling sites depicted in these plots are shown in figure 2, but a brief description of their location and their west to east orientation will be given here. LWR 794 is the most upstream site on the Little Wind River and is located in the southwest corner of figure 2. DOE well 720 is adjacent to route 137 (the road that runs diagonally across figure 2) on the west side of figure 2. DOE well 718 is also adjacent to route 137 east of well 720 . DOE wells 710 , $101,716,722 \mathrm{R}$, and 707 are located in the central axis of the plume starting with DOE well 710 at the northwest end of the plume extending to DOE well 707 at the southeast end of the plume adjacent to the Little Wind River. DOE well 706 is due south of well 707 adjacent to the south bank of the Little Wind River. DOE well 729 is adjacent to route 137 east of well 722R. The DOE sampling sites on the Little Wind River, LWR 811, LWR 812, and LWR 796, are east of well 707.

Water-quality data collected from two other wells in the upper unconfined alluvial aquifer, domestic well 445 and
DOE well 789, were not shown in figures 40 and 41 , because of limited data available for each of these wells. Only three unfiltered samples exist for domestic well 445 (east of DOE well 729) (table 7). A few unfiltered samples analyzed for sulfate, molybdenum, and uranium were collected from DOE well 789 located on the north side of the Little Wind River directly south of DOE well 707. Nine samples collected from DOE well 789 between June 6, 2007, and November 3, 2010 , had a median sulfate concentration of $4,000 \mathrm{mg} / \mathrm{L}$ and a median molybdenum concentration of $500 \mu \mathrm{g} / \mathrm{L}$. Ten samples collected from DOE well 789 between March 21, 2007, and November 3, 2010, had a median uranium concentration of $1,600 \mu \mathrm{g} / \mathrm{L}$.

\section{Arsenic}

Dissolved arsenic is distributed fairly uniformly across the UMTRA site in the upper confined alluvial aquifer, with the highest median concentration occurring in DOE well 101 (fig. 40). There were no arsenic concentration data available for DOE well 722R. Although the highest median concentration was in DOE well 101, concentrations measured in individual samples collected from DOE well 707 were greater than in DOE well 101 in the past. In DOE well 707, the highest dissolved arsenic concentrations were measured in three samples collected on November 21, $1987(19 \mu \mathrm{g} / \mathrm{L})$, February 20, $1988(13 \mu \mathrm{g} / \mathrm{L})$, and May 16, $1988(32 \mu \mathrm{g} / \mathrm{L})$. Between September 1, 1988, and May 13, 2003, the highest reported concentration was $1.5 \mu \mathrm{g} / \mathrm{L}$.

Arsenic concentration data in DOE wells screened in the intermediate semiconfined bedrock aquifer were limited. Enough data for a comparison between the upper unconfined alluvial aquifer and the intermediate semiconfined bedrock aquifer were only available for DOE wells 716 and 717 and 718 and 719 (fig. 40). In the few samples available for each of the other DOE wells screened in the intermediate semiconfined bedrock aquifer $(111,702,735,721$, and 730 ), the concentration was either less than 10 or less than $5 \mu \mathrm{g} / \mathrm{L}$. There were five samples with measurable amounts of dissolved arsenic in DOE well 735, but the highest concentration was $1.6 \mu \mathrm{g} / \mathrm{L}$. Due to the number of samples with concentrations less than the multiple detection limits in

Table 7. Concentration of arsenic, molybdenum, nickel, and uranium measured in unfiltered samples collected from domestic well 445.

[Concentration in $\mu \mathrm{g} / \mathrm{L}$, micrograms per liter; $<$, less than]

\begin{tabular}{ccccc}
\hline Date & Arsenic & Molybdenum & Nickel & Uranium \\
\hline $1 / 7 / 1994$ & 8 & $<10$ & $<40$ & 16 \\
$2 / 10 / 1997$ & 4.5 & 2.5 & $<7.8$ & 12.3 \\
$5 / 15 / 1998$ & 4.4 & 2.6 & $<5.6$ & 12.5 \\
\hline
\end{tabular}



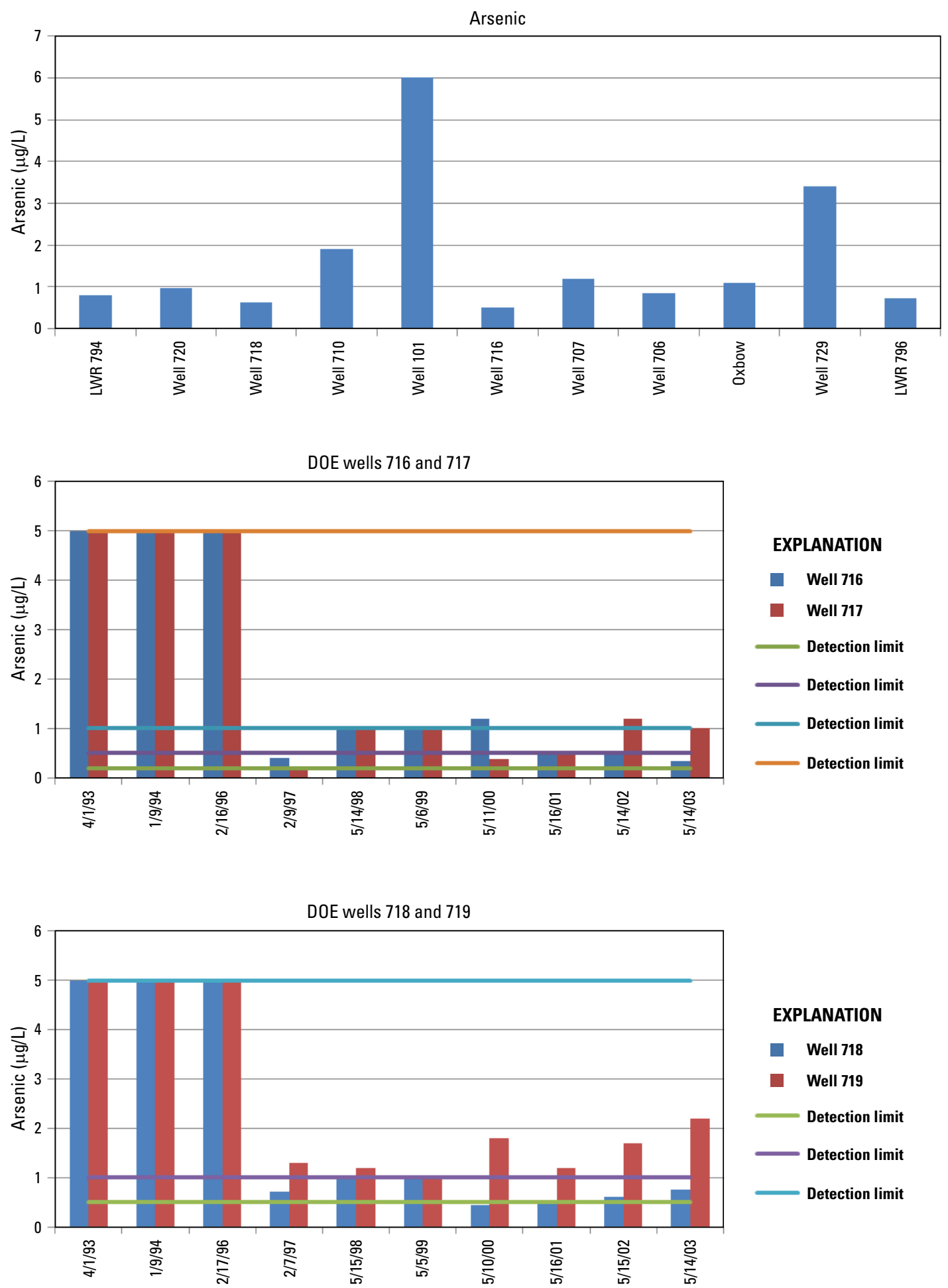

Figure 40. Median concentrations of $A$, arsenic and $B$, comparison of arsenic concentrations in the upper unconfined alluvial aquifer and the intermediate semiconfined bedrock aquifer at two locations. $\mu \mathrm{g} / \mathrm{L}$, micrograms per liter. 
A
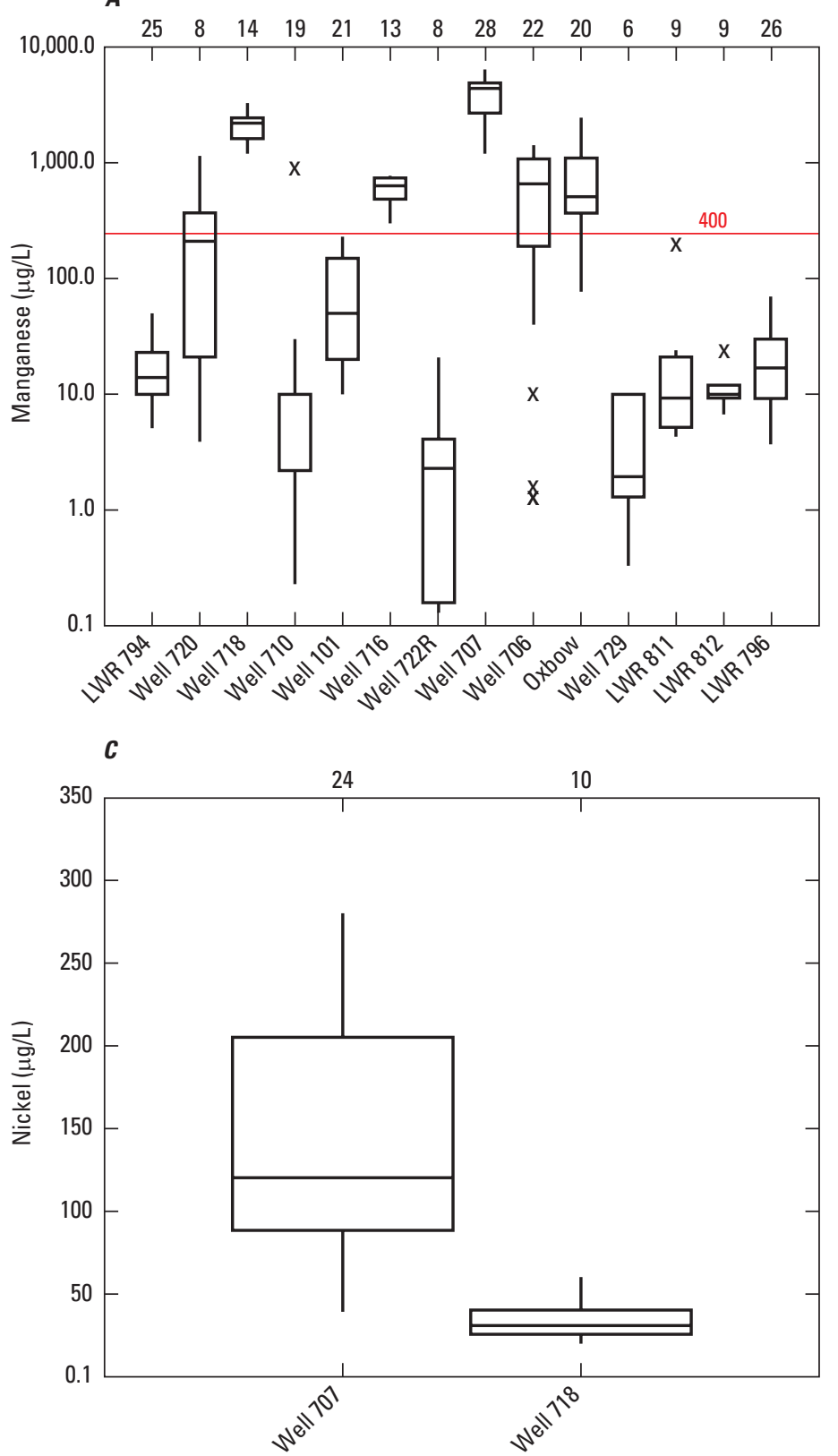

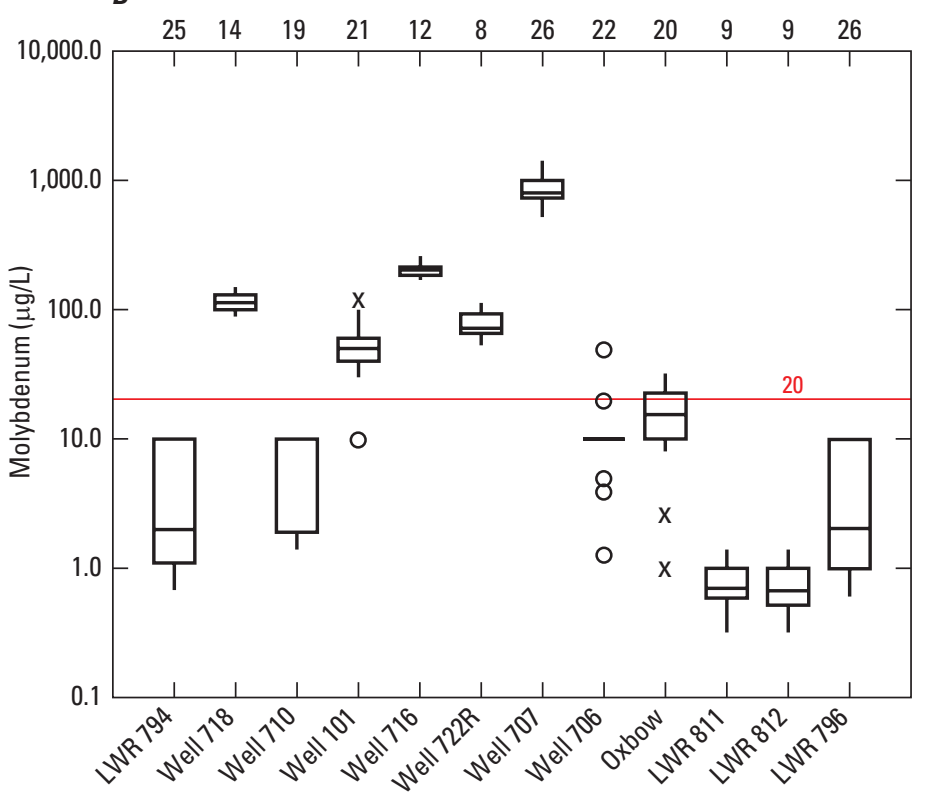

\section{EXPLANATION}

Schematic boxplot

30 Number of values

- Upper detached

$x \quad$ Upper outside

Upper adjacent

75th percentile

Median

25th percentile

Lower adjacent

Lower outside

Lower detached

400 Concentration above

which background is

thought to be exceede

in groundwater

Figure 41. Concentrations of $A$, manganese; $B$, molybdenum; $C$, nickel; $D$, sulfate; and $E$, uranium in the upper unconfined alluvial aquifer throughout the UMTRA site. $\mu \mathrm{g} / \mathrm{L}$, micrograms per liter. 


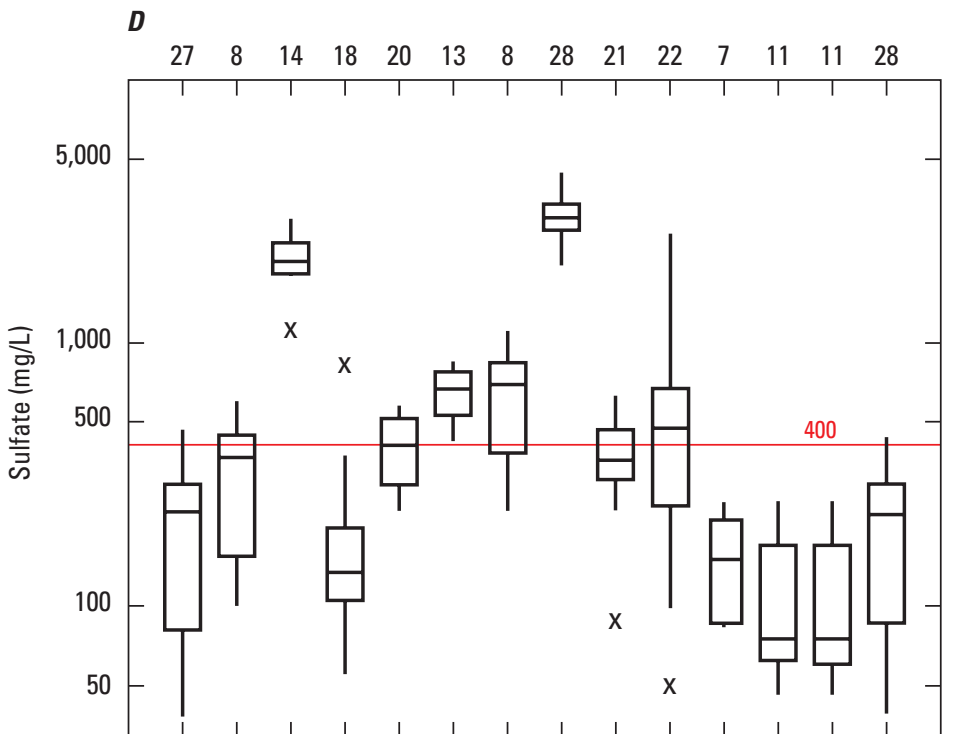

$E$

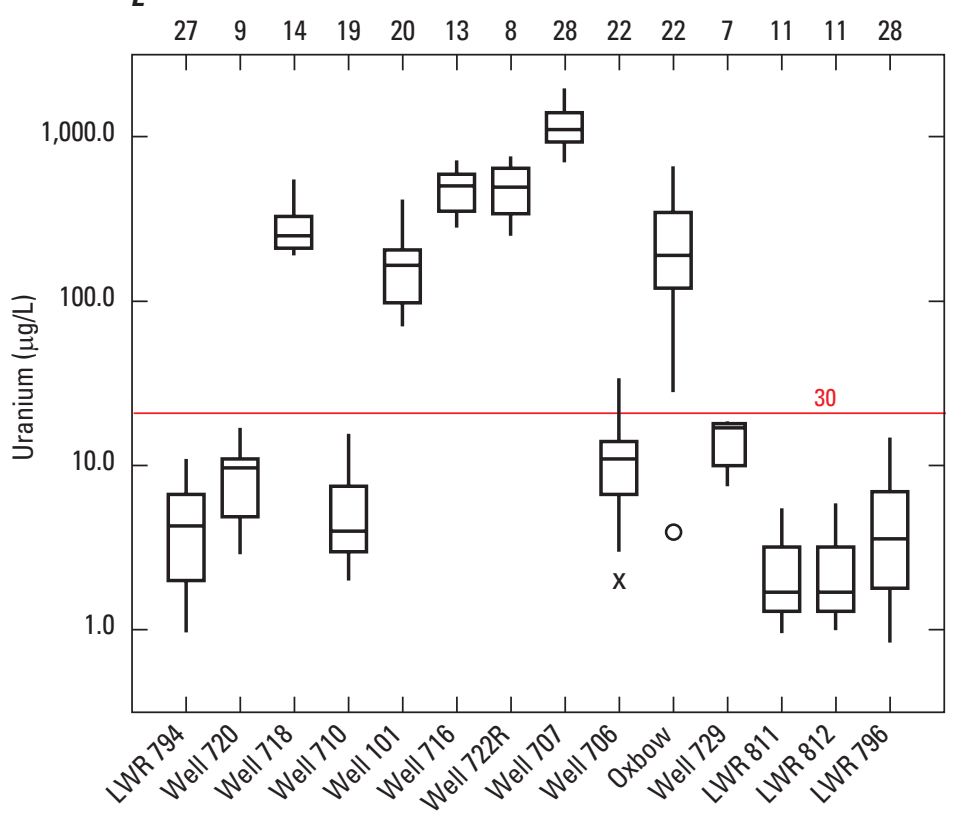

EXPLANATION

Schematic boxplot

30 Number of values

○ Upper detached

X Upper outside Upper adjacent

75th percentile

Median

25th percentile

Lower adjacent

Lower outside

Lower detached

400

Concentration above which background is

thought to be exceeded

in groundwater

Figure 41. Concentrations of $A$, manganese; $B$, molybdenum; $C$, nickel; $D$, sulfate; and $E$, uranium in the upper unconfined alluvial aquifer throughout the UMTRA site. $\mu \mathrm{g} / \mathrm{L}$, micrograms per liter; $\mathrm{mg} / \mathrm{L}$, milligrams per liter.-Continued 
A

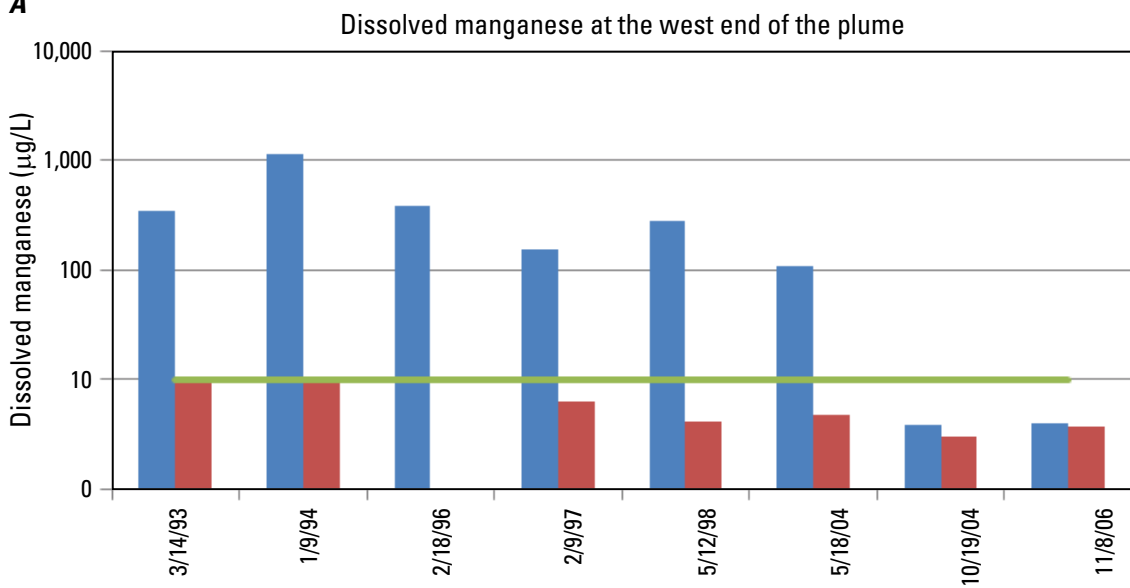

\section{EXPLANATION}

- Well 720

- Well 721

Detection limit
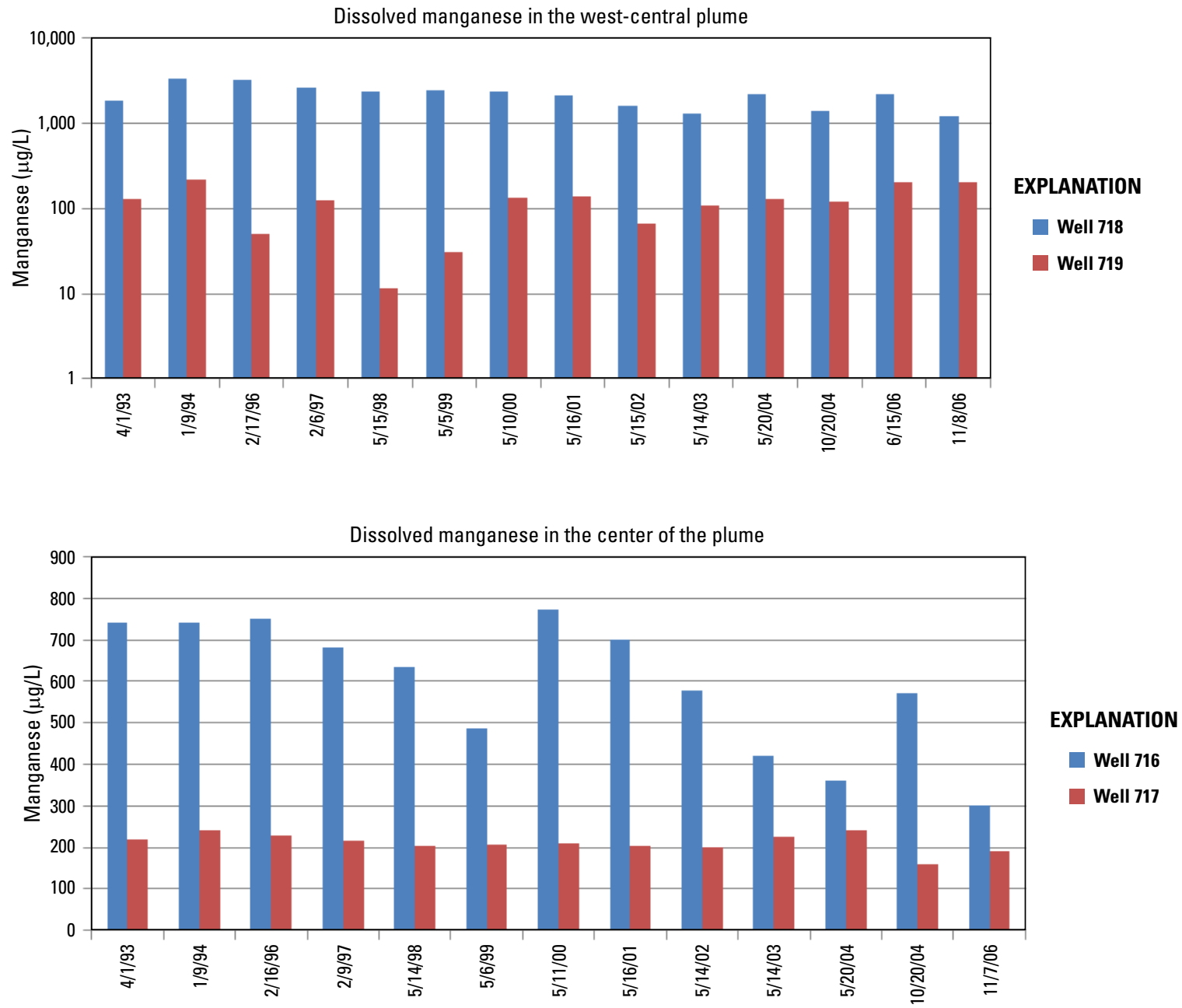

Figure 42. A, Time-series plots of the concentration of manganese along on an east-west axis through the Uranium Mill Tailings Remedial Action (UMTRA) site. $B$, Time-series plots of the concentration of molybdenum along on an east-west axis through the UMTRA site. $C$, Time-series plots of the concentration of sulfate along on an east-west axis through the UMTRA site. $D$, Time-series plots of the concentration of uranium along on an east-west axis through the UMTRA site. $\mu \mathrm{g} / \mathrm{L}$, micrograms per liter. 
$\boldsymbol{A}$
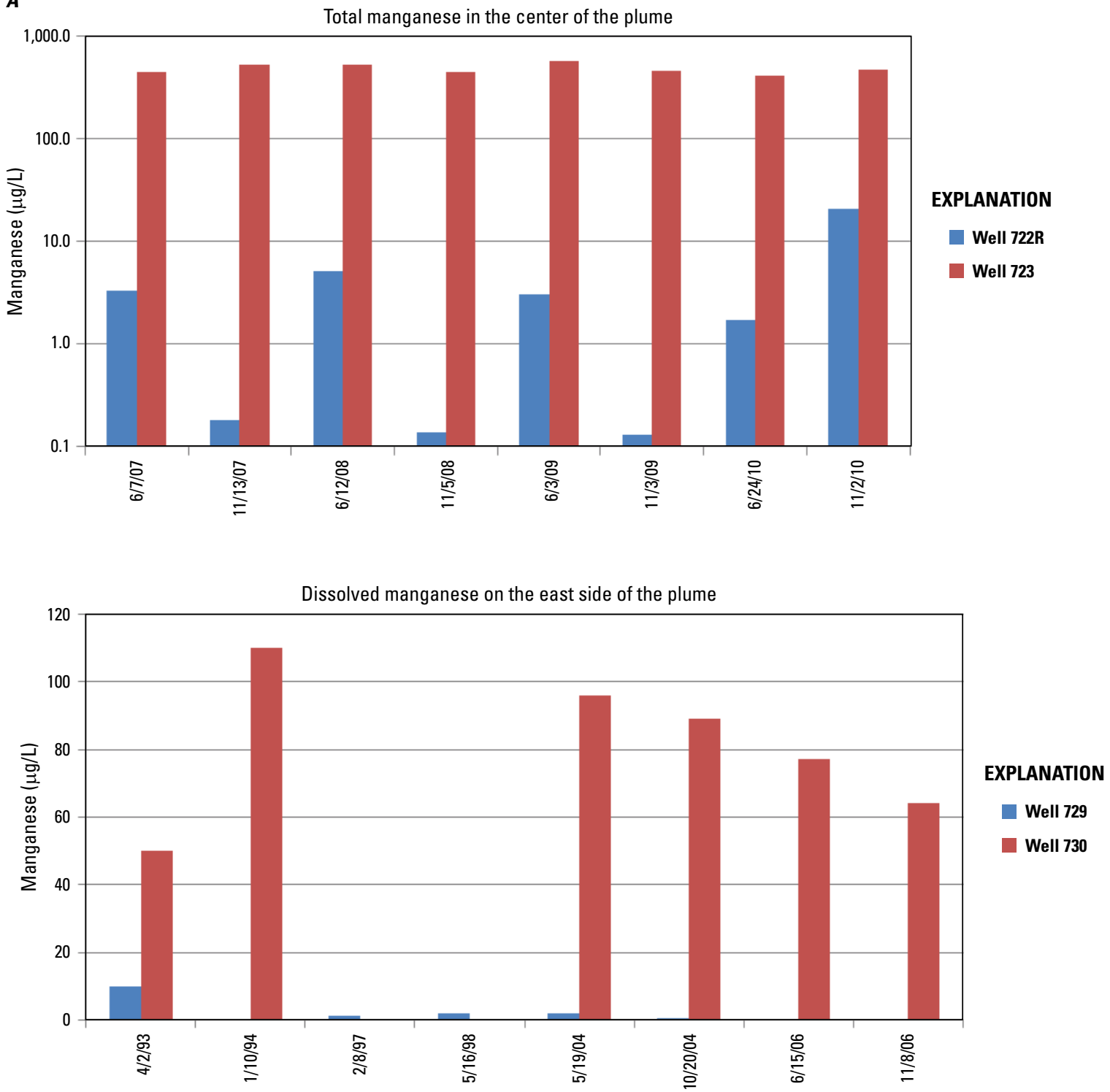

Figure 42. A, Time-series plots of the concentration of manganese along on an east-west axis through the Uranium Mill Tailings Remedial Action (UMTRA) site. $B$, Time-series plots of the concentration of molybdenum along on an east-west axis through the UMTRA site. $C$, Time-series plots of the concentration of sulfate along on an east-west axis through the UMTRA site. $D$, Time-series plots of the concentration of uranium along on an east-west axis through the UMTRA site. $\mu \mathrm{g} / \mathrm{L}$, micrograms per liter-Continued 
B
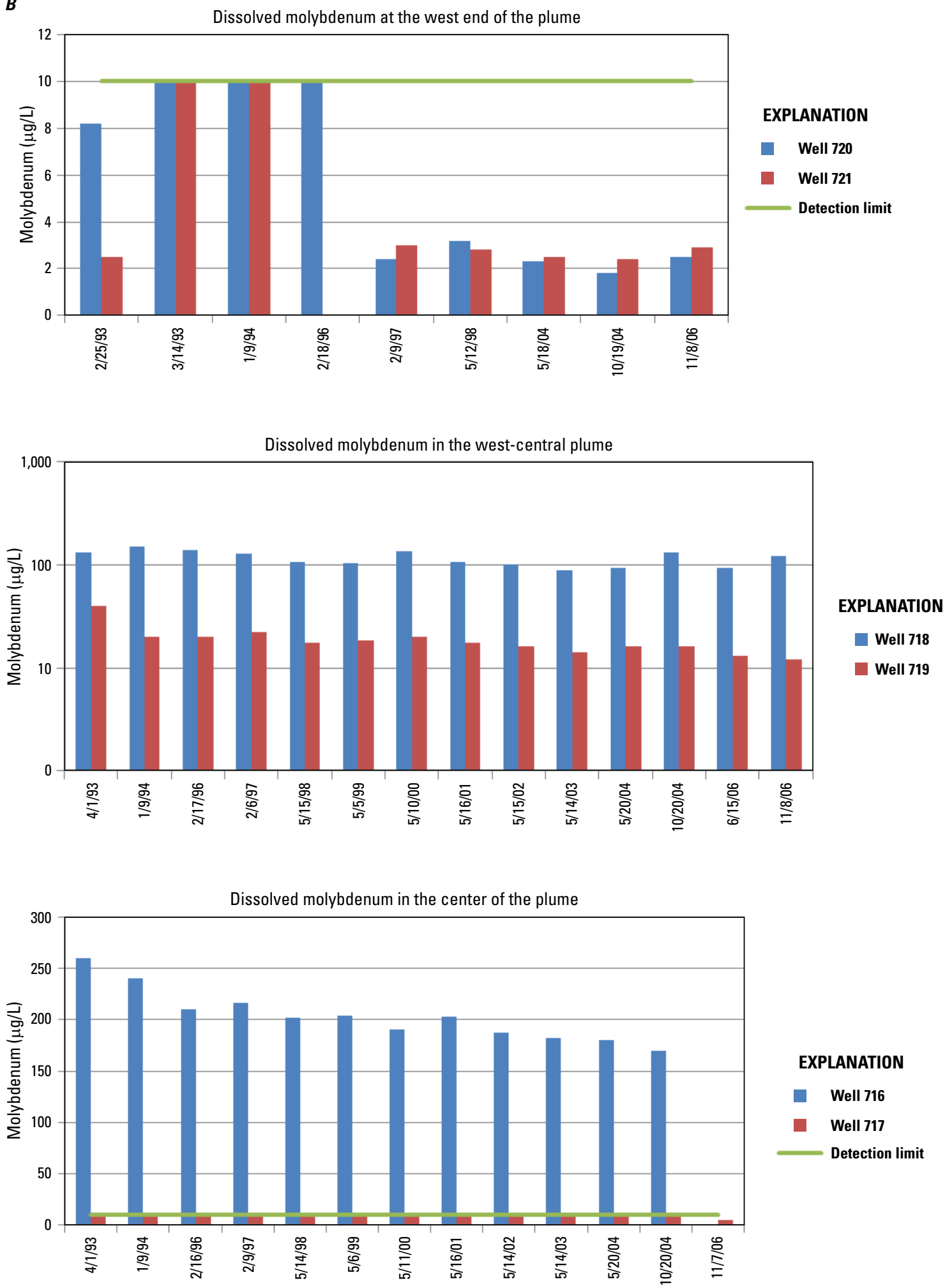

Figure 42. $A$, Time-series plots of the concentration of manganese along on an east-west axis through the Uranium Mill Tailings Remedial Action (UMTRA) site. B, Time-series plots of the concentration of molybdenum along on an east-west axis through the UMTRA site. C, Time-series plots of the concentration of sulfate along on an east-west axis through the UMTRA site. $D$, Time-series plots of the concentration of uranium along on an east-west axis through the UMTRA site. $\mu \mathrm{g} / \mathrm{L}$, micrograms per liter.-Continued 

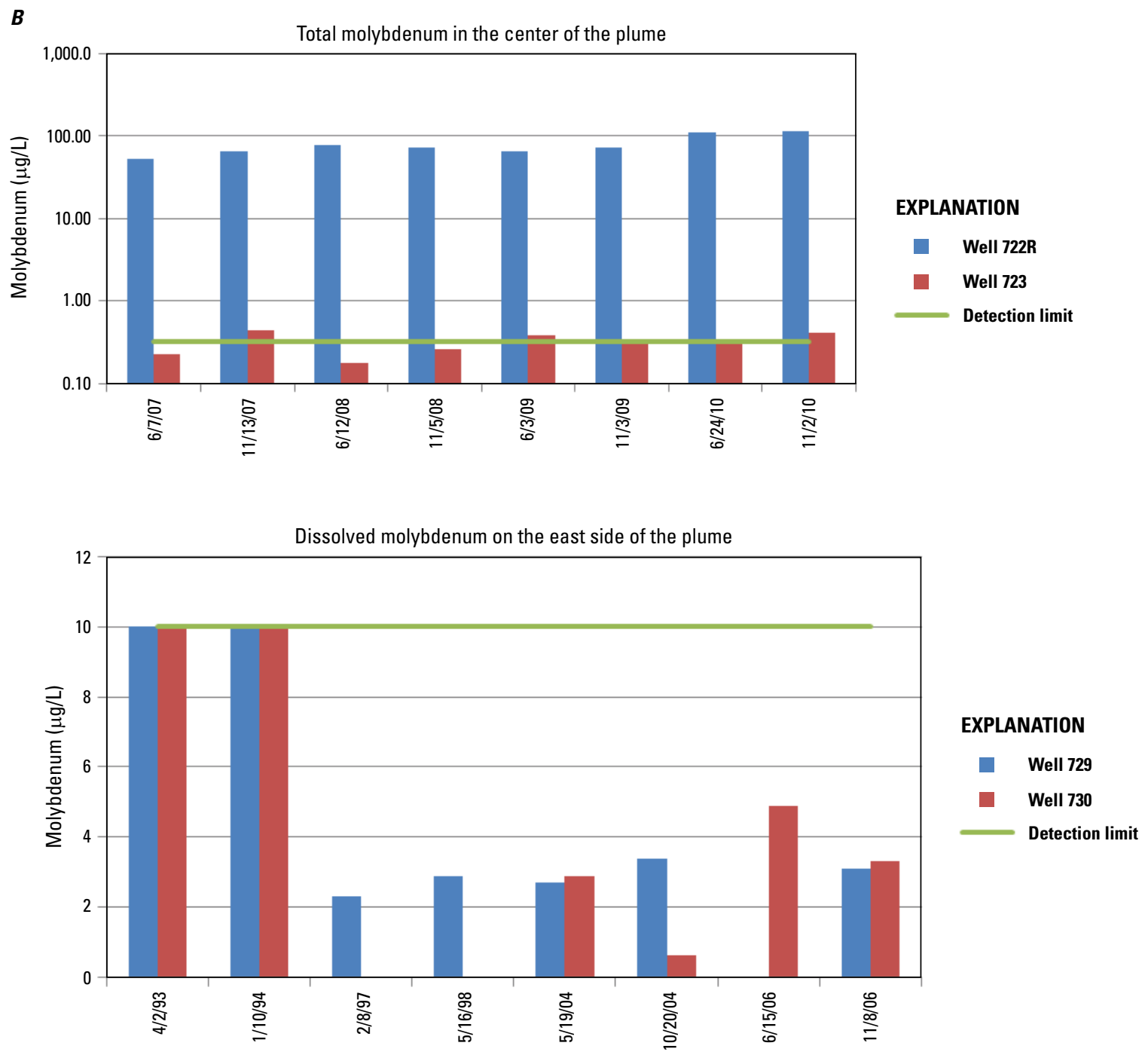

Figure 42. A, Time-series plots of the concentration of manganese along on an east-west axis through the Uranium Mill Tailings Remedial Action (UMTRA) site. $B$, Time-series plots of the concentration of molybdenum along on an east-west axis through the UMTRA site. $C$, Time-series plots of the concentration of sulfate along on an east-west axis through the UMTRA site. $D$, Time-series plots of the concentration of uranium along on an east-west axis through the UMTRA site. $\mu \mathrm{g} / \mathrm{L}$, micrograms per liter-—Continued 
C
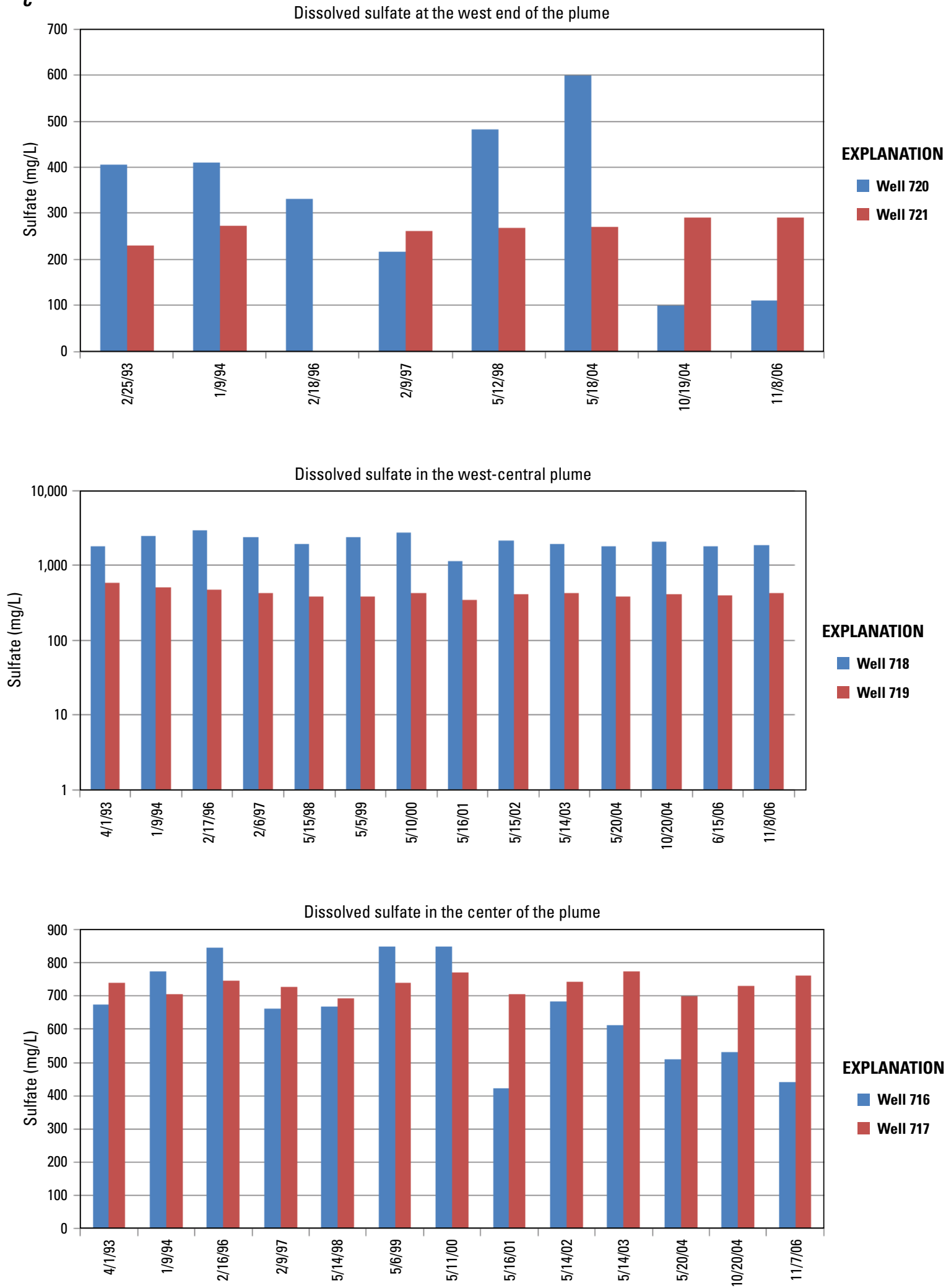

Figure 42. A, Time-series plots of the concentration of manganese along on an east-west axis through the Uranium Mill Tailings Remedial Action (UMTRA) site. $B$, Time-series plots of the concentration of molybdenum along on an east-west axis through the UMTRA site. $C$, Time-series plots of the concentration of sulfate along on an east-west axis through the UMTRA site. $D$, Time-series plots of the concentration of uranium along on an east-west axis through the UMTRA site. $\mathrm{mg} / \mathrm{L}$, milligrams per liter.-Continued 
C
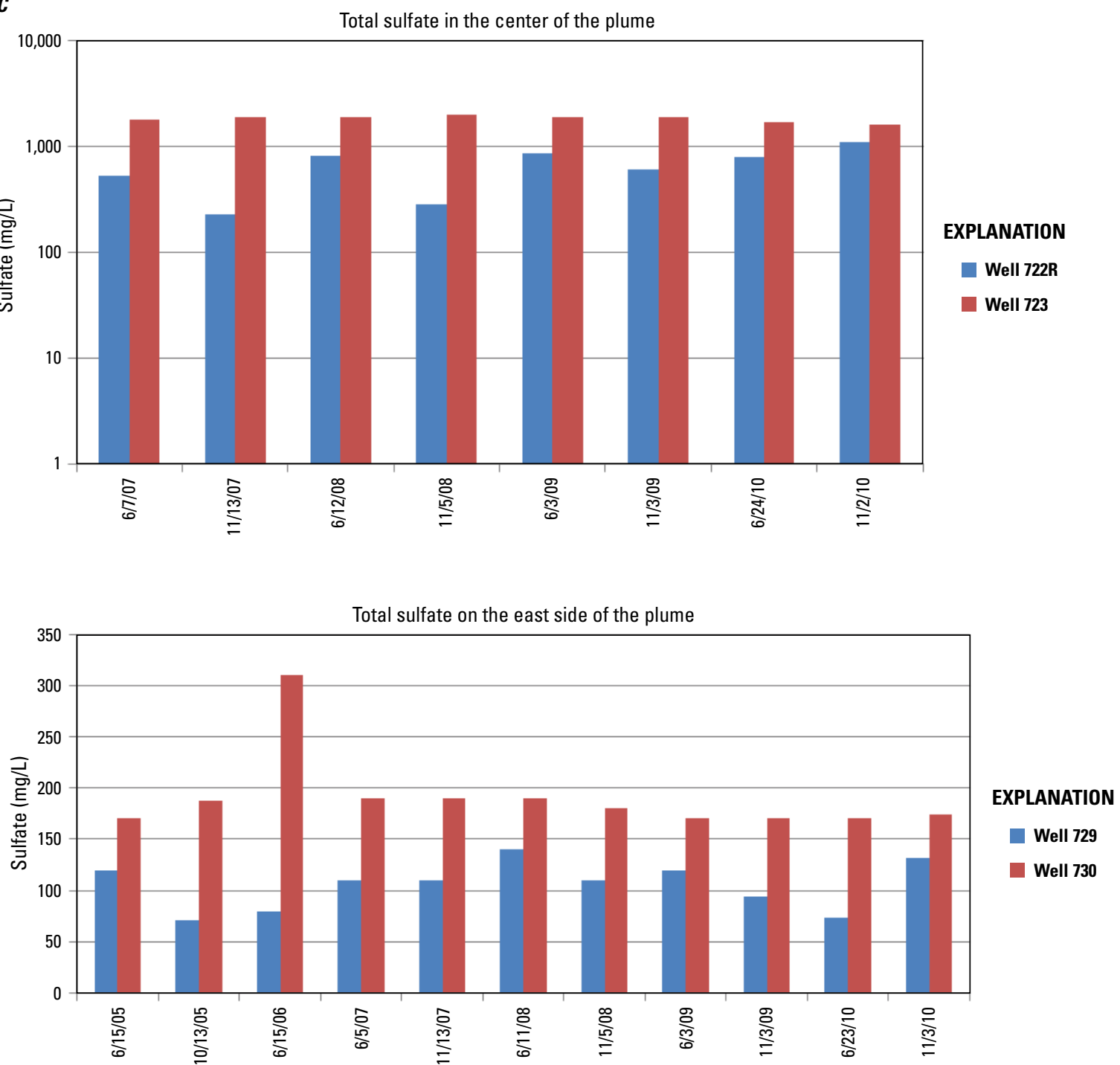

Figure 42. A, Time-series plots of the concentration of manganese along on an east-west axis through the Uranium Mill Tailings Remedial Action (UMTRA) site. $B$, Time-series plots of the concentration of molybdenum along on an east-west axis through the UMTRA site. C, Time-series plots of the concentration of sulfate along on an east-west axis through the UMTRA site. $D$, Time-series plots of the concentration of uranium along on an east-west axis through the UMTRA site. $\mathrm{mg} / \mathrm{L}$, milligrams per liter.-Continued 
D
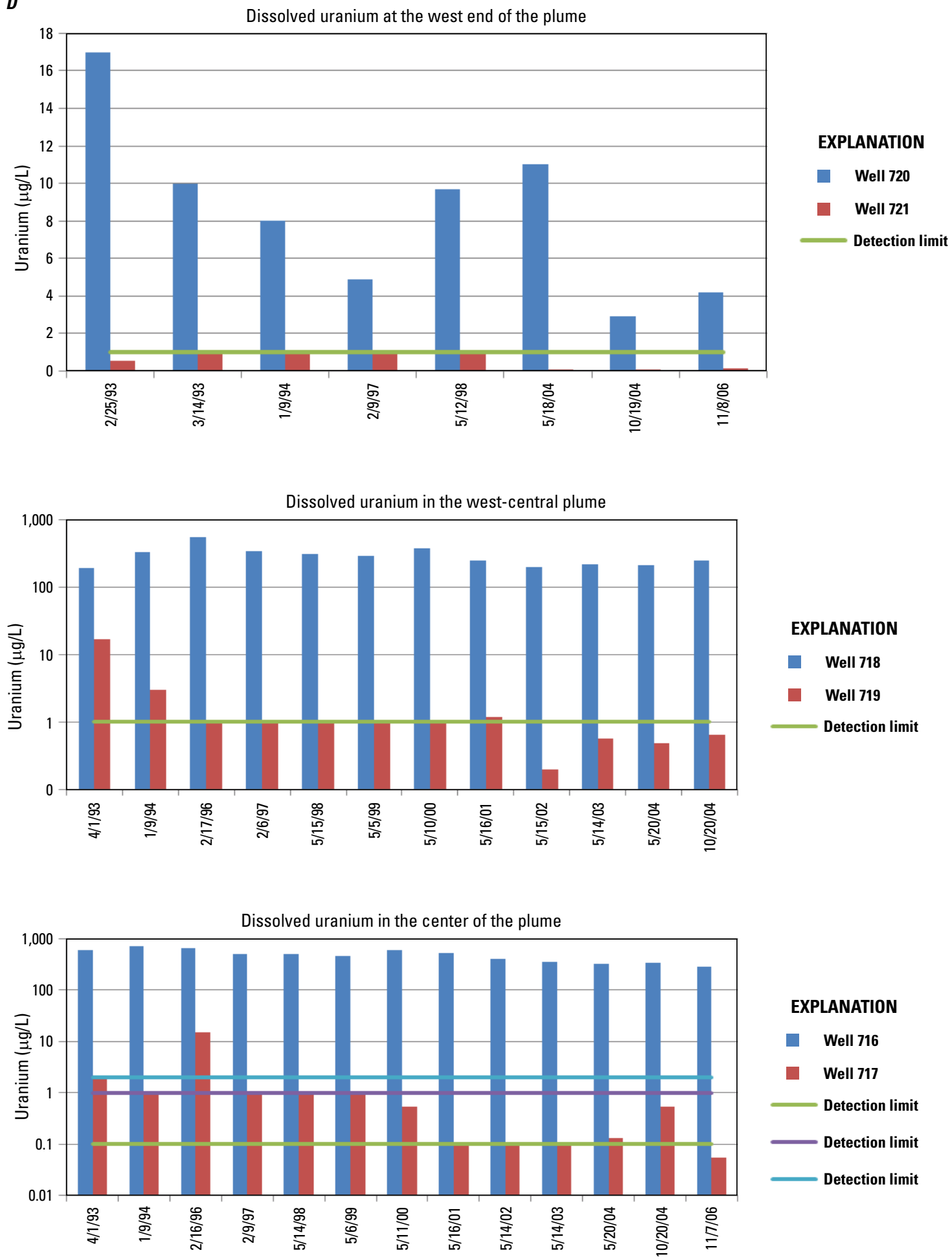

Figure 42. $A$, Time-series plots of the concentration of manganese along on an east-west axis through the Uranium Mill Tailings Remedial Action (UMTRA) site. $B$, Time-series plots of the concentration of molybdenum along on an east-west axis through the UMTRA site. $C$, Time-series plots of the concentration of sulfate along on an east-west axis through the UMTRA site. $D$, Time-series plots of the concentration of uranium along on an east-west axis through the UMTRA site. $\mu \mathrm{g} / \mathrm{L}$, micrograms per liter.-Continued 
D
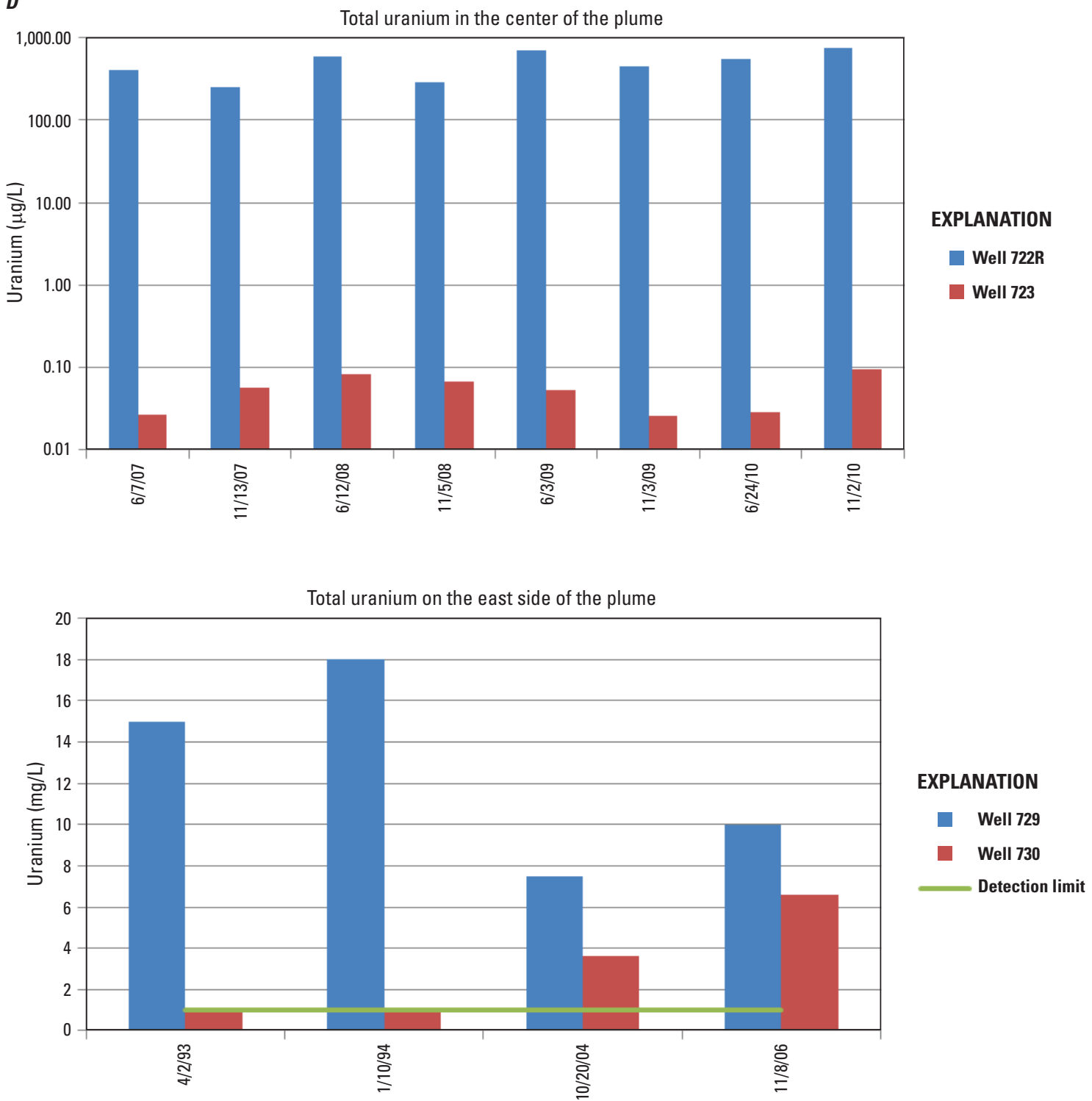

Figure 42. A, Time-series plots of the concentration of manganese along on an east-west axis through the Uranium Mill Tailings Remedial Action (UMTRA) site. $B$, Time-series plots of the concentration of molybdenum along on an east-west axis through the UMTRA site. $C$, Time-series plots of the concentration of sulfate along on an east-west axis through the UMTRA site. $D$, Time-series plots of the concentration of uranium along on an east-west axis through the UMTRA site. $\mu \mathrm{g} / \mathrm{L}$, micrograms per liter; $\mathrm{mg} / \mathrm{L}$, milligrams per liter.-Continued 
each well, it is only possible to state that the concentration of arsenic in each aquifer appears to be similar and has not been measured above $5 \mu \mathrm{g} / \mathrm{L}$ since the early 1990s.

Arsenic (As) speciation and saturation indices were calculated for samples collected from DOE well 101 on February 8, $1997(\mathrm{As}=3.9 \mu \mathrm{g} / \mathrm{L})$, from DOE well 716 on February 9, $1997(\mathrm{As}=0.4 \mu \mathrm{g} / \mathrm{L})$, and from DOE well 707 on February 9, $1997($ As $=1.0 \mu \mathrm{g} / \mathrm{L})($ table 2$)$. In each sample, arsenic exists in solution only as $\mathrm{As}^{+5}$, and the groundwater is very undersaturated with respect to arsenolite $\left(\mathrm{As}_{2} \mathrm{O}_{3}\right)$. The speciation of arsenic in solution may explain the low concentrations of dissolved arsenic in the groundwater at the UMTRA site. Arsenic in the +5 valence state strongly sorbs to iron and aluminum oxyhydroxides (Frankenberger, 2002), and because the groundwater in the upper unconfined alluvial aquifer is usually well oxygenated, arsenic will occur in this valence state and will tend to sorb to the sediments in this aquifer. Under reducing conditions, however, iron and aluminum oxyhydroxides can dissolve and release arsenic into solution in the +3 valence state (Frankenberger, 2002), which does not sorb to sediments as strongly. Thus, arsenic will be more mobile in groundwater under reducing conditions.

\section{Manganese}

Manganese concentrations above background concentrations in the upper unconfined alluvial aquifer are highly variable (table 3), which makes an assessment of manganese derived from the former mill site difficult. A comparison of the concentrations of manganese (fig. $41 A$ ) with the concentrations in the background wells, however, indicates that manganese concentrations above background in the upper unconfined alluvial aquifer extend from DOE well 716 through Oxbow Lake (site 747) to DOE wells 707 and 789 and beyond the Little Wind River to DOE well 706. From west to east, manganese concentrations above background extend from DOE 720 to somewhere west of DOE Well 722R. Manganese concentration data for DOE well 720 (fig. 42) indicate that manganese concentrations above background did extend to DOE well 720 but since late 2004 have decreased to background levels.

An assessment of manganese derived from the former mill site in the intermediate semiconfined bedrock aquifer is also difficult because the number of samples in the background wells with manganese concentration data in this aquifer is limited (table 4). Based on a comparison of the data in table 3 with figures 25 and 42, however, it does appear that manganese above-background concentrations are present in the intermediate semiconfined bedrock aquifer in the area of DOE wells 111 and 723.

Manganese (Mn) speciation and saturation indices were calculated for samples in the contaminated plume collected from DOE well 101 on February 8, $1997(\mathrm{Mn}=165 \mu \mathrm{g} / \mathrm{L})$, DOE well 716 on April 1, $1993(\mathrm{Mn}=740 \mu \mathrm{g} / \mathrm{L})$ and February 9, $1997(\mathrm{Mn}=681 \mu \mathrm{g} / \mathrm{L})$, and DOE well 717 on April 1, $1993(\mathrm{Mn}=220 \mu \mathrm{g} / \mathrm{L})$ and February 9, $1997(\mathrm{Mn}$ $=216 \mu \mathrm{g} / \mathrm{L})($ table 2$)$. In each sample manganese exists in solution primarily as $\mathrm{Mn}^{2+}$ and secondarily evenly divided between $\mathrm{MnHCO}_{3}{ }^{+}$and $\mathrm{MnSO}_{4}$. Except for the samples collected from DOE wells 716 and 717 on April 1, 1993, all samples were undersaturated with respect to various solidphase manganese compounds such as manganite $(\mathrm{MnOOH})$ and pyrolusite $\left(\mathrm{MnO}_{2}\right)$. The sample collected from DOE well 716 on April 1, 1993, was saturated with respect to manganite and pyrolusite and undersaturated with respect to $\mathrm{MnSO}_{4}$ and rhodochrosite. The sample collected from DOE well 717 on April 1, 1993, was saturated with respect to manganite but undersaturated with respect to pyrolusite $\left(\mathrm{MnO}_{2}\right)$ and rhodochrosite $\left(\mathrm{MnCO}_{3}\right)$. Except under highly oxidizing conditions, as occurred on April 1, 1993, when manganese thermodynamically could precipitate from solution, manganese should be mobile in both aquifers throughout the UMTRA site as it exists primarily as $\mathrm{Mn}^{2+}$, which should limit adsorption, and is undersaturated with respect to various solid phases.

This is a good example of how important it is to understand seasonal variations in redox conditions as a potential control on the mobility of manganese and other redox sensitive COCs. Changes in redox conditions can be responsible for the variation in the manganese concentration data in each aquifer because lower redox conditions can be an in-place source of manganese, and manganese (whether derived from natural sources or the former mill) can precipitate out of solution under oxidizing conditions. An inspection of the saturation indices for the various solid-phase manganese compounds shown in table 2 indicates that the groundwater in each aquifer becomes undersaturated with respect to manganese oxide compounds such as manganite, nsutite, and pyrolusite as redox condition of the groundwater becomes less oxidizing.

\section{Molybdenum}

Molybdenum concentrations above background in the upper unconfined alluvial aquifer occur between DOE well 718 on the west, somewhere east of DOE well 722R, and west of DOE well 729 and between DOE well 101 through Oxbow Lake to DOE wells 707 and 789 (fig. 41B). The median concentration of molybdenum increases from DOE well 101 to DOE well 716, decreases slightly to DOE well 722R, and then increases again and is at its highest value in DOE well 707 and does not appear to have migrated across the Little Wind River (fig. 41B).

Molybdenum does not appear to be migrating down into the intermediate semiconfined bedrock aquifer; however, the molybdenum concentrations in water from DOE well 719 are consistently higher than concentrations in other wells in this aquifer. It is difficult to determine if this is evidence of migration into this aquifer because these concentrations do not exceed background concentrations by much. The concentrations measured in DOE well 719, however, range from 12 to $40 \mu \mathrm{g} / \mathrm{L}$, whereas in all of the other samples collected from wells screened in the intermediate semiconfined bedrock aquifer, the concentration rarely exceeds the detection 
limit. It was stated previously that molybdenum would be mobile in groundwater but the reason for the apparent migration of molybdenum into the intermediate semiconfined bedrock aquifer in the area of DOE well 719 and only in this area is not known.

\section{Nickel}

Nickel concentrations in the upper unconfined alluvial aquifer are larger than in the intermediate semiconfined bedrock aquifer exclusively in the area between DOE wells 707 and 718 (fig. 41C). The concentration of nickel is consistently below the detection limit in DOE well 101. There were several samples with measurable amounts of nickel in samples collected from DOE well 716, but none were greater than $11.8 \mu \mathrm{g} / \mathrm{L}$. There were no nickel data for DOE well 722R. There were only a few samples with dissolved nickel data available for each DOE well in the intermediate semiconfined bedrock aquifer (DOE wells 111, 717, 702, 735, 721, 719, and 730). In each of these samples the concentration of nickel was less than $40 \mu \mathrm{g} / \mathrm{L}$. The reason for the absence of measurable amounts of nickel in the intermediate semiconfined bedrock aquifer and the more limited spatial distribution within the upper unconfined alluvial aquifer than uranium is not known.

\section{Sulfate}

Sulfate concentrations above background in the upper unconfined alluvial aquifer occur between DOE well 718 on the west, somewhere east of DOE well 722R, and west of DOE well 729 and between DOE well 101 through Oxbow Lake to DOE wells 707 and 789. The median concentration of sulfate increases from DOE well 101 to equal values in DOE wells 716 and $722 \mathrm{R}$ and then increases again to the highest concentration in DOE well 707 and does appear to have migrated across the Little Wind River (fig. 41D; DOE well 706).

Sulfate does appear to be present in concentrations above background in the intermediate semiconfined aquifer in the area of DOE wells 705, 717, 719, 723, 732, and 735. Sulfate appears to have migrated across the Little Wind River in this aquifer (fig. 27; DOE well 735).

Although sulfate is normally a mobile anion, precipitation of sulfate as barite could occur throughout the upper unconfined alluvial aquifer and as gypsum in the area of DOE well 707 (table 2). Precipitation as gypsum does not appear to be occurring in the lower two aquifers, but barium data were lacking in the lower two aquifers so it was not possible to calculate a saturation index for barite.

\section{Uranium}

Uranium concentrations above background occur exclusively in the upper unconfined alluvial aquifer between DOE well 718 on the west to somewhere east of DOE well 722R, west of DOE well 729, and between DOE well 101 and the Little Wind River. Uranium does not appear to be migrating across the Little Wind River (fig. 28, DOE well 706). Uranium (U) speciation and saturation indices were calculated for samples in the contaminated plume collected from DOE well 101 on February 8, $1997(\mathrm{U}=83.5 \mu \mathrm{g} / \mathrm{L})$, DOE well 716 on April 1, $1993(\mathrm{U}=591 \mu \mathrm{g} / \mathrm{L})$, DOE well 716 on February 9, $1997(\mathrm{U}=513 \mu \mathrm{g} / \mathrm{L})$, and DOE well 707 on February 9, $1997(\mathrm{U}=1,550 \mu \mathrm{g} / \mathrm{L})$ under oxidizing conditions and yielded identical results to the upgradient wells described in the "Background Concentrations of the Contaminants of Concern" section. In all of these samples, uranium exists in solution completely as $\mathrm{Ca}_{2} \mathrm{UO}_{2}\left(\mathrm{CO}_{3}\right)_{3}$ and $\mathrm{CaUO}_{2}\left(\mathrm{CO}_{3}\right)_{3}{ }^{2-}$ and is very undersaturated with respect to coffinite, rutherfordine, schoepite, uraninite, and uranophane. Thus, uranium is very mobile in the upper unconfined alluvial aquifer because the complexes in which uranium occurs in solution will not tend to sorb to aquifer materials, and there is no tendency for uranium to participate out of solution.

In the intermediate semiconfined aquifer, uranium does not occur above background concentrations, and in most samples it occurs below the detection limit. The reason for the absence of measurable concentrations of uranium when there is evidence for the migration of manganese, molybdenum (possibly), and sulfate from the upper unconfined alluvial aquifer into this aquifer is not known.

\section{Time Series}

The time series plots for manganese, molybdenum, sulfate, and uranium for five sets of nested wells indicate some variability in concentration over time within each aquifer but differences between aquifers in each set of wells is consistent (fig. 42). The data, however, were not collected frequently enough to define seasonal variability. The most noticeable patterns over time occur with manganese and sulfate in DOE well 720 and molybdenum in DOE well 716. Concentrations of manganese and sulfate in DOE well 720 were either above, at, or slightly below background prior to October 2004 but were below background in the two samples collected in October 2004 and November 2006. The concentration of molybdenum in DOE well 716 has been steadily declining since April 1993 but is still well above background.

\section{Boron, Iron, Lead, Selenium, and Vanadium}

Due to either limited data availability or much of the data reported as below the detection limit, it was not possible to interpret the boron, iron, lead, selenium, and vanadium data collected by the DOE. Summary tables for these data in each aquifer are presented in tables 8 and 9. Boron data were available only for DOE wells 101 (two samples, both at $100 \mu \mathrm{g} / \mathrm{L}$ ), 707 (two samples, both at $200 \mu \mathrm{g} / \mathrm{L}$ ), and 706 (three samples, two $<100 \mu \mathrm{g} / \mathrm{L}$, one at $100 \mu \mathrm{g} / \mathrm{L}$ ). In the upper unconfined alluvial aquifer, there were three selenium samples (DOE well 707) that exceeded the State of Wyoming groundwater-quality standard for irrigation (table 1). There 
Table 8. Summary of the available iron, lead, selenium, and vanadium concentration data in U.S. Department of Energy wells in the contaminated groundwater plume in the upper unconfined alluvial aquifer.

[concentration in $\mu \mathrm{g} / \mathrm{L}$, micrograms per liter; DOE, Department of Energy; <, less than; -, no data]

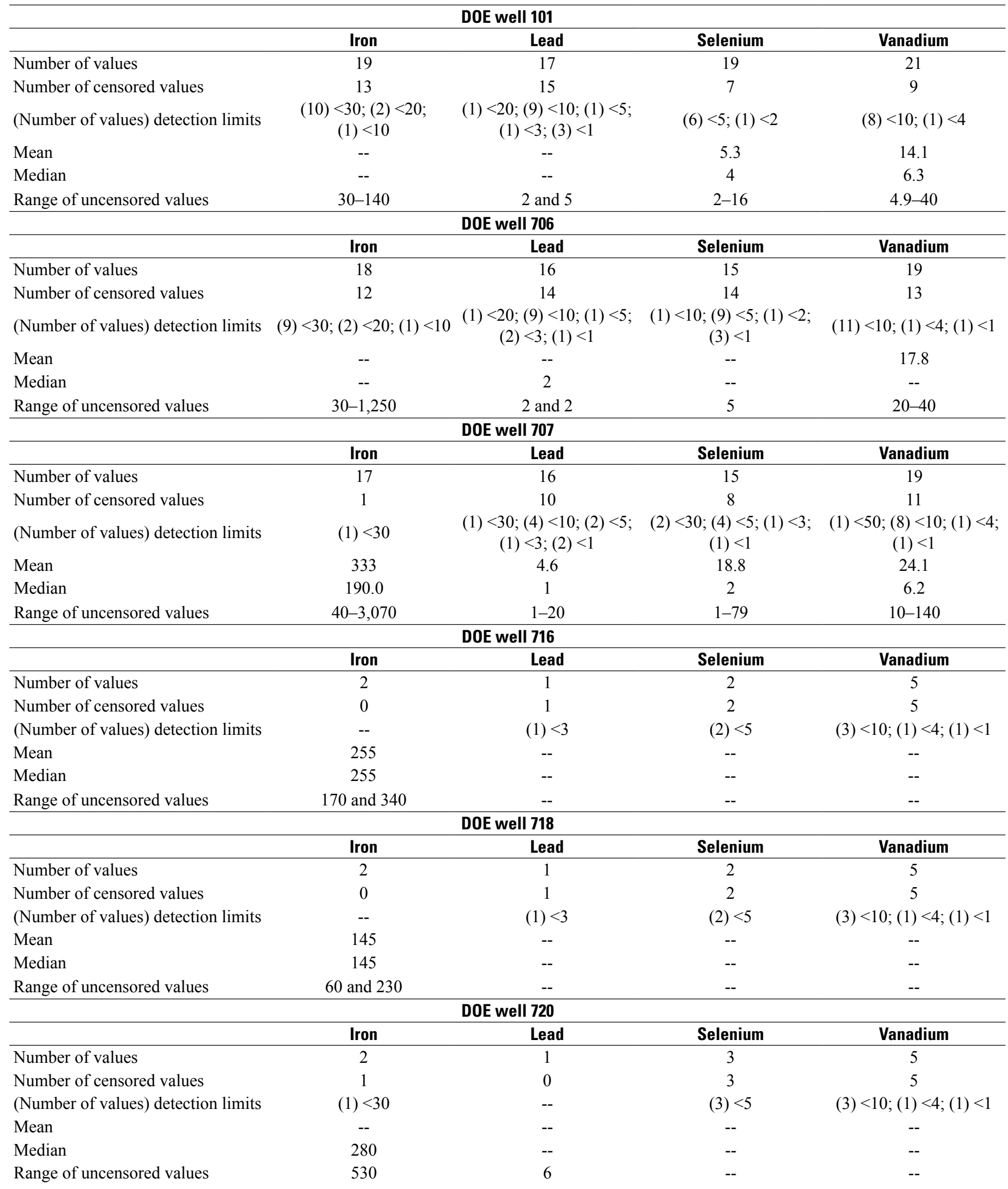


Table 8. Summary of the available iron, lead, selenium, and vanadium concentration data in U.S. Department of Energy wells in the contaminated groundwater plume in the upper unconfined alluvial aquifer-Continued

[concentration in $\mu \mathrm{g} / \mathrm{L}$, micrograms per liter; DOE, Department of Energy; <, less than; --, no data]

\begin{tabular}{|c|c|c|c|c|}
\hline \multicolumn{5}{|c|}{ DOE well 729} \\
\hline & Iron & Lead & Selenium & Vanadium \\
\hline Number of values & 1 & 1 & 1 & -- \\
\hline Number of censored values & 1 & 1 & 1 & -- \\
\hline (Number of values) detection limits & $(1)<30$ & $(1)<3$ & $(1)<5$ & -- \\
\hline Mean & -- & -- & -- & -- \\
\hline Median & -- & -- & -- & -- \\
\hline Range of uncensored values & -- & -- & -- & -- \\
\hline
\end{tabular}

Table 9. Summary of the available iron, lead, selenium, and vanadium concentration data in U.S. Department of Energy wells in the contaminated groundwater plume in the intermediate semiconfined bedrock aquifer.

[concentration in $\mu \mathrm{g} / \mathrm{L}$, micrograms per liter; DOE, Department of Energy; $<$, less than; --, no data]

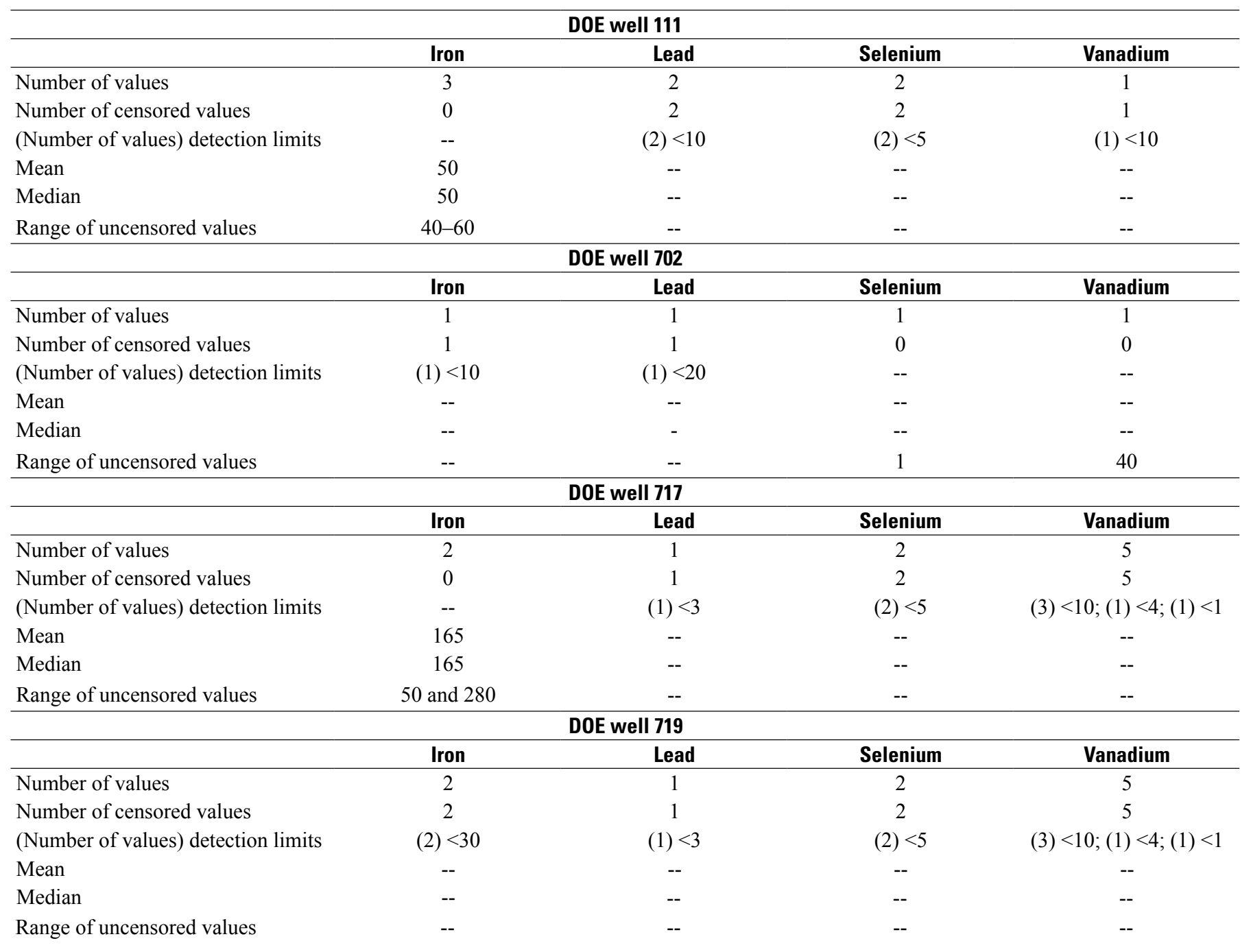


Table 9. Summary of the available iron, lead, selenium, and vanadium concentration data in U.S. Department of Energy wells in the contaminated groundwater plume in the intermediate semi-confined bedrock aquifer.-Continued

[concentration in $\mu \mathrm{g} / \mathrm{L}$, micrograms per liter; DOE, Department of Energy; <, less than; --, no data]

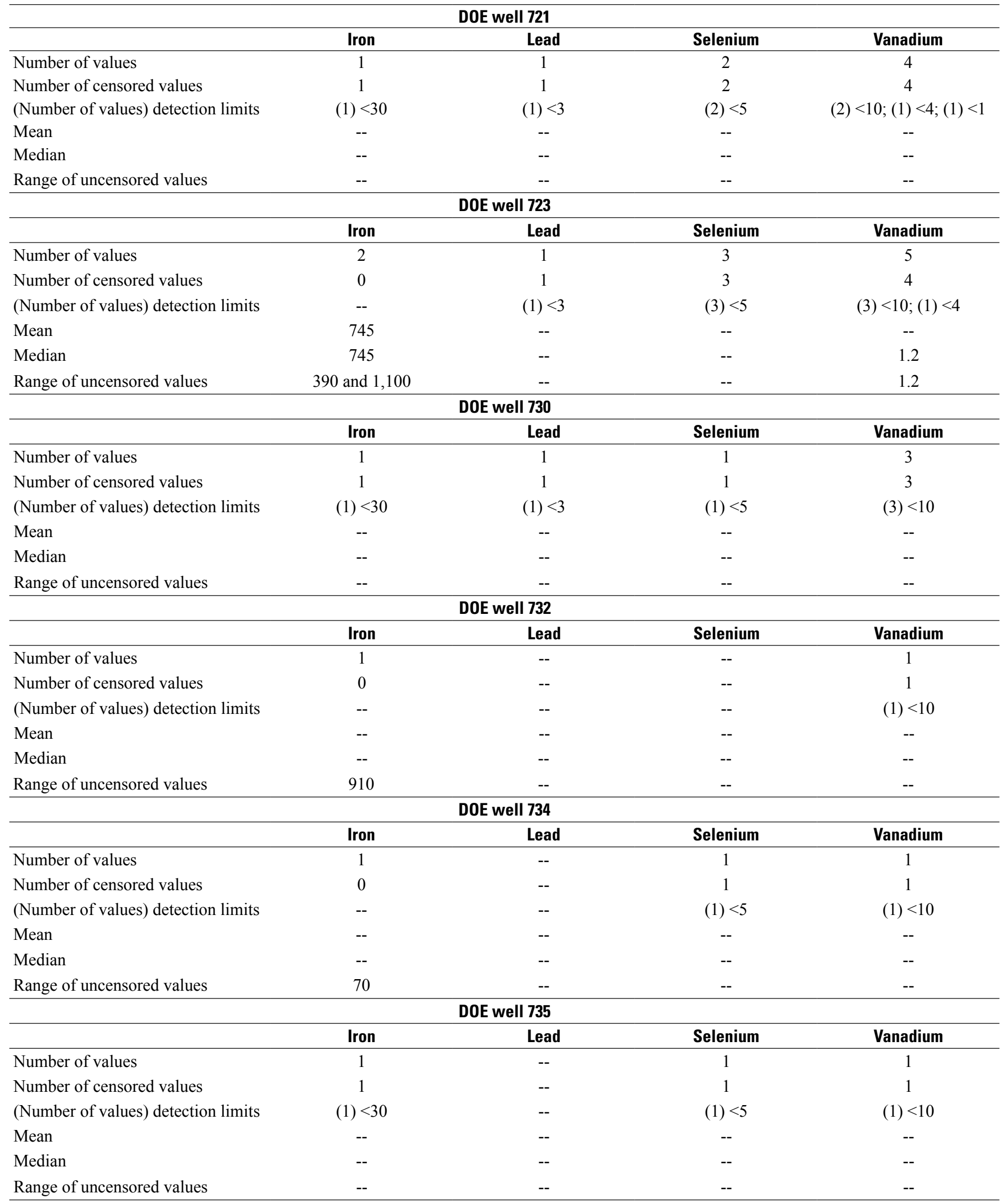



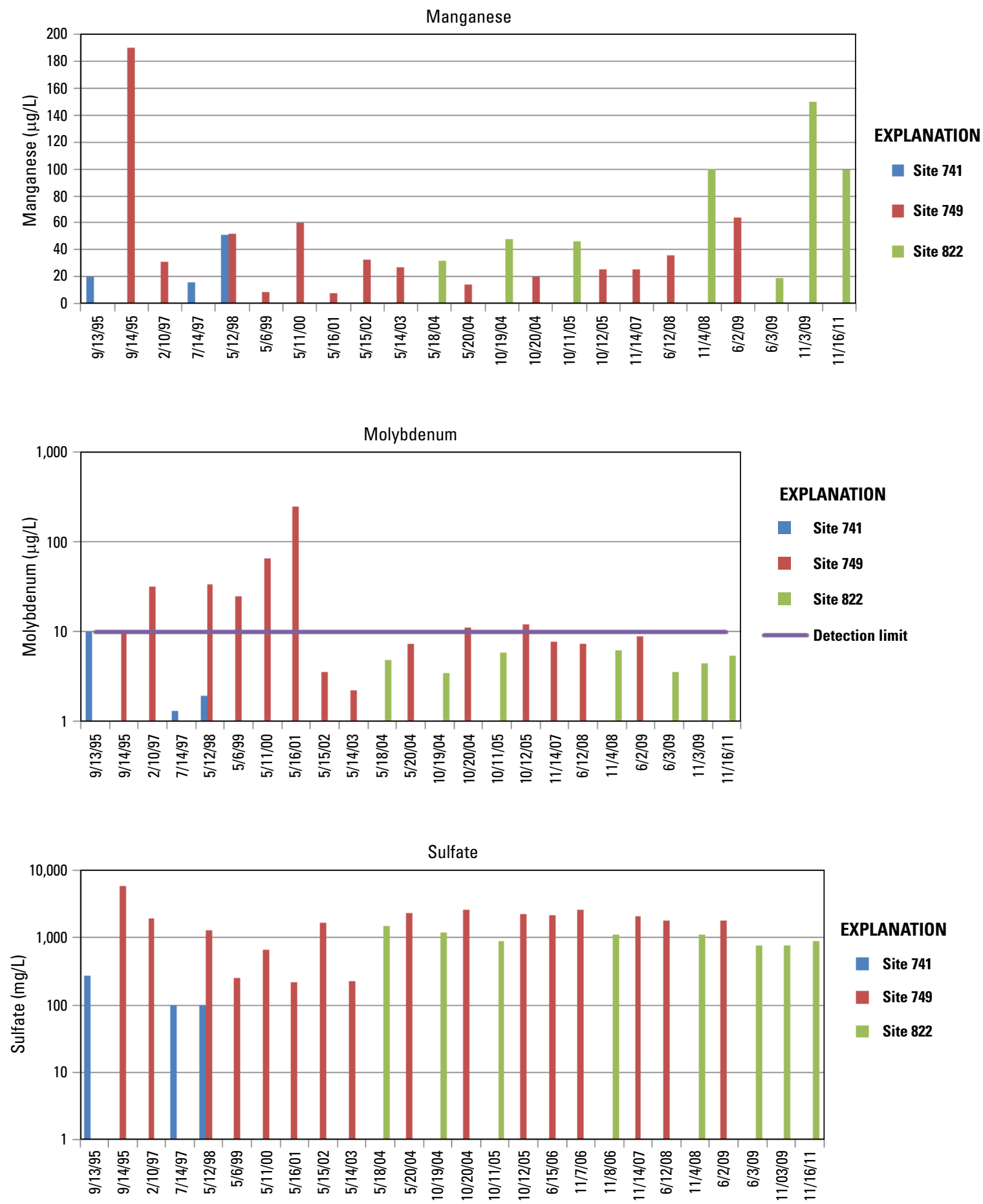

Figure 43. Time-series plots of the concentration of dissolved manganese, molybdenum, sulfate, and uranium in the Koch drainage ditch and West Side Creek. $\mu \mathrm{g} / \mathrm{L}$, micrograms per liter; $\mathrm{mg} / \mathrm{L}$, milligrams per liter. 


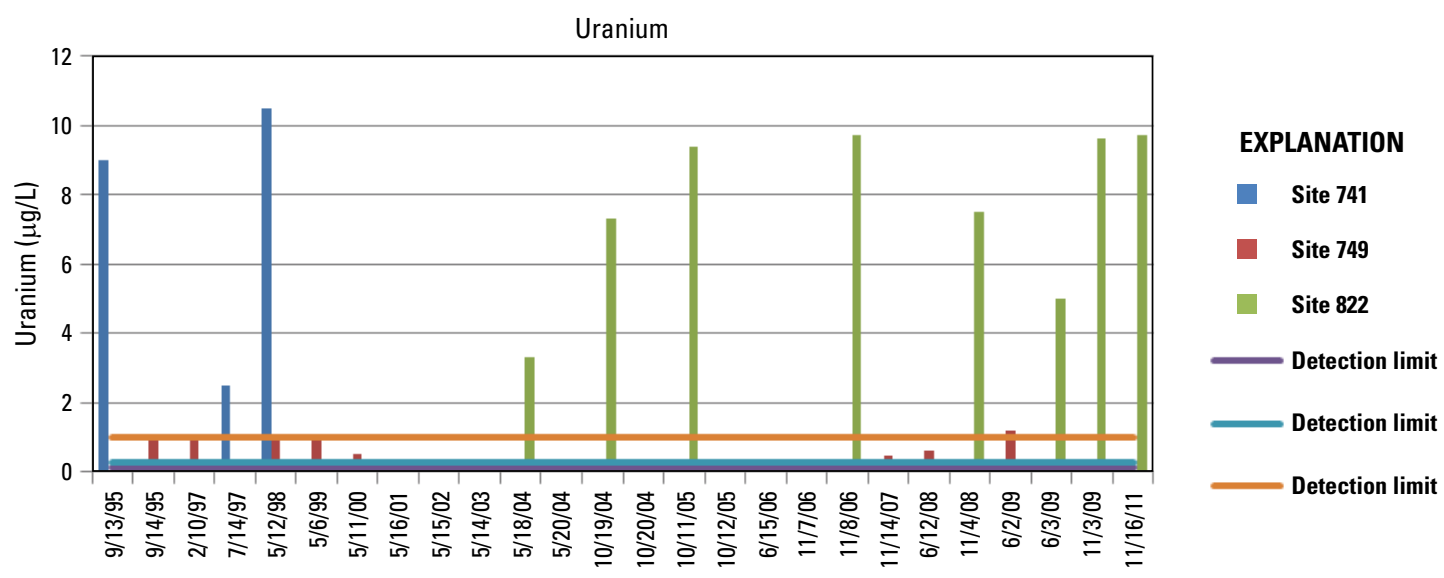

Figure 43. Time-series plots of the concentration of dissolved manganese, molybdenum, sulfate, and uranium in the Koch drainage ditch and West Side Creek. $\mu \mathrm{g} / \mathrm{L}$, micrograms per liter.-Continued

were no exceedances of any water-quality standard by any $\mathrm{COC}$ in the intermediate semiconfined bedrock aquifer. None of the COC data samples were collected after 1996. All of the exceedances occurred in the late 1980s and early 1990s. Whether or not the limited data available for these COCs represent a data gap will need to be discussed further by the WREQC and DOE.

In summary, the available data have adequately delineated the horizontal extent of the contaminated groundwater plume in the upper unconfined alluvial aquifer. Overall, each of the COCs and COPCs lies within an area between DOE well 718 on the west, between DOE well 722R and DOE well 729 on the east, and from DOE well 101 on the northwest trending southeast down to the Little Wind River. Within this area, however, there is some variability as to the distribution of each COC and COPC. Arsenic concentrations are fairly uniformly distributed throughout the upper unconfined alluvial aquifer and have been below the EPA MCL of $10 \mu \mathrm{g} / \mathrm{L}$ since the early $1990 \mathrm{~s}$. Manganese concentrations above background appear to have extended west to DOE well 720 in the past, but since at least late 2004, concentrations have receded to background levels at this well. Molybdenum concentrations above background follow the distribution described above, but unlike manganese, never appear to have extended to DOE well 720 . Nickel concentrations in the upper unconfined alluvial aquifer larger than in the intermediate semiconfined bedrock aquifer only occur between DOE wells 718 and 707. Sulfate concentrations above background are similar to manganese except that it does appear that sulfate may have migrated across the Little Wind River. Uranium concentrations above background are similar to molybdenum.

The horizontal extent of the contaminated groundwater plume in the intermediate semiconfined bedrock aquifer is also adequately delineated, but contamination is not as extensive as that in the upper unconfined alluvial aquifer. There is evidence of migration of manganese and sulfate into this aquifer but only within a limited area. Manganese and sulfate concentrations above background are found in the area of DOE wells 723 and 732. Manganese-only concentrations above background are found in the area of well 111.

Molybdenum-only concentrations above background are found in the area of DOE well 719. Sulfate-only concentrations above background are found in the area of DOE wells 705, 717,719 , and 735 and do appear to have migrated across the Little Wind River (DOE well 735). The high concentrations of manganese and sulfate could be naturally occurring due to dissolution as a result of changing redox conditions and (or) from localized sources of minerals such as gypsum.

The available data allow for some understanding of the mobility of the COCs in each aquifer, but an understanding of the seasonal variations of redox conditions in the upper unconfined alluvial aquifer and the intermediate semiconfined aquifer is needed to understand the mobility of redox sensitive elements. In general, each COC and COPC, except arsenic, is likely to be very mobile in each aquifer as there is little tendency for any $\mathrm{COC}$ and $\mathrm{COPC}$ to sorb to aquifer materials or precipitate out of solution. The solubility of several of these COCs and COPCs, however, is dependent on the redox conditions of the groundwater. PHREEQC modeling of several samples with high concentrations of dissolved oxygen indicated that manganese could precipitate out of solution as manganite and pyrolusite. Conversely, when groundwater approached reducing conditions in the intermediate semiconfined bedrock aquifer, groundwater was approaching equilibrium with coffinite and uraninite. The modeling also indicates that when measurable amounts of barium are present, sulfate can precipitate out of solution as barite throughout the UMTRA site, and gypsum can precipitate out of solution in the area of DOE well 707. 


\section{The Influence of Groundwater Discharged from the Sulfuric-Acid Plant Site on Water Quality in the Little Wind River}

Groundwater discharged from the sulfur-acid plant is released to a drainage ditch that flows into West Side Creek, which in turn flows into the Little Wind River (fig. 2). The WREQC needs an assessment of the potential of West Side Creek to affect the water quality of the Little Wind River. The concentrations of manganese, molybdenum, sulfate, and uranium in the Koch drainage ditch were compared to (1) concentrations in West Creek upstream and downstream from the confluence of the ditch and West Side Creek and (2) concentrations in West Side Creek upstream and downstream from the confluence of West Creek and the Little Wind River. Data for the other COCs were not available. The sampling sites used in this evaluation are as follows:

- Site 749-Koch drainage ditch,

- Site 741-West Side Creek upstream from the confluence with the Koch drainage ditch, and

- Site 822-West Side Creek downstream from the confluence with the Koch drainage ditch.

Time-series plots of the concentration of dissolved manganese, molybdenum, sulfate, and uranium are shown in figure 43. Almost all of the sampling dates have data for just one site. There are few data available for the upstream site (741), but a few observations can be made about the influence of the Koch drainage ditch on West Side Creek and West Side Creek on the Little Wind River.

The Koch drainage ditch does not appear to be a source of uranium to West Side Creek. No sample analyzed for uranium that was collected from the Koch drainage ditch was ever greater than $1 \mu \mathrm{g} / \mathrm{L}$. The concentration of uranium in both the upstream and downstream sites in West Side Creek were greater than that measured in the Koch drainage ditch and about equal to each other but were within the background concentrations measured in groundwater and the Little Wind River (site 794 in the Little Wind River; fig. 41E).

The Koch drainage ditch does not appear to be a source of manganese to West Side Creek either, because the concentration measured in water from the three surfacewater sites is within concentrations measured in upgradient groundwater. Although the concentration of manganese in the downstream site appears to be greater than that of the upstream site, without any concurrent samples collected from sites 741 and 822, it is not possible to determine the effect on inflows from the Koch drainage ditch on West Side Creek. The concentration of manganese in several samples collected from West Side Creek (822) is greater than that measured at any site in the Little Wind River indicating that manganese contributed to the Little Wind River is being diluted in the river (fig. 41A).

The Koch drainage ditch appears to have been a source of molybdenum in the late 1990s through 2001, but since the sample collected on May 15, 2002, the concentration has been less than $10 \mu \mathrm{g} / \mathrm{L}$ and about equal to that measured in site 822 . The concentration of molybdenum in the Little Wind River downstream from the confluence with West Side Creek is less than that measured in site 822 indicating that the Little Wind River is diluting the molybdenum flowing into it from the West Side Creek.

The Koch drainage ditch is a source of sulfate to West Side Creek. The concentrations in the ditch are greater than in either the upstream or downstream site in West Side Creek, and the concentration in the downstream site is greater than that in the upstream site. The concentration of sulfate in the Little Wind River downstream from the confluence with West Side Creek (fig. 41D-sites LWR 811, LWR812, and LWR 796), however, is much less than that in site 822 indicating that the Little Wind River is diluting the sulfate flowing into it from West Side Creek.

The limited data available indicate that the Koch drainage ditch is affecting only the concentration of sulfate to any measurable degree in West Side Creek. The data also seem to indicate that the concentrations of COCs in West Side Creek are being diluted in the Little Wind River. A quantitative assessment of the influence of the Koch drainage ditch on West Side Creek and the influence of West Side Creek on the Little Wind River is needed and might be accomplished by collecting water-quality samples and measuring discharge concurrently from the Koch drainage ditch, site 741, site 822, and in the Little Wind River upstream and downstream from the confluence with West Side Creek. The discharge measurements will allow for mass balance calculations that can quantify the amount of dilution occurring in West Side Creek and the Little Wind River. Analysis of $\delta^{18} \mathrm{O}_{\text {sulfate }}$ and $\delta^{34} \mathrm{~S}_{\text {sulfate }}$ collected from these sites would also be useful in assessing the influence of the sulfur plant on the sulfate concentration in West Side Creek.

\section{Summary}

In 2010, the U.S Geological Survey, in cooperation with the Wind River Environmental Quality Commission (WREQC), began an assessment of the effectiveness of the existing monitoring network at the Riverton, Wyoming, Uranium Mill Tailings Remedial Action (UMTRA) Project site. The USGS began the assessment using existing data supplied by the U.S. Department of Energy (DOE). The study was to determine (1) seasonal variations in direction of groundwater flow in the area of the former uranium processing facility toward the Little Wind River, (2) the extent of contaminated groundwater among the aquifers and between the aquifers and the Little Wind River, (3) if current monitoring is adequate to establish the effectiveness of natural attenuation for the contaminants of concern, and (4) the influence of groundwater discharged from the sulfuric-acid plant on water quality in the Little Wind River.

Seasonal variations in the directions of groundwater flow in the area of the former uranium processing facility 
were evaluated by comparing groundwater elevations in U.S. Department of Energy (DOE) wells 710, 101, 728, 716, 722R, and 707 and uranium and sulfate concentrations in DOE wells 710,711 , and 101 for the period of record. These wells lie along the axis of the flow path delineated by the DOE in the upper unconfined alluvial aquifer. Both the groundwater-elevation and concentration data indicate no evidence of groundwater flow from the UMTRA site toward the Wind River.

The extent of contaminated groundwater among the aquifers was evaluated by comparing groundwater elevations, major ion chemistry, and the median concentrations of manganese, molybdenum, sulfate, and uranium in 11 groups of nested DOE monitoring wells and a principal components analysis of all the groundwater- and surface-water-quality data. Groundwater in the lower confined bedrock aquifer does not appear to be vulnerable to contamination from the upper unconfined alluvial aquifer. There is evidence of contaminated groundwater having migrated down into the intermediate semiconfined aquifer in several areas as concentrations of manganese and sulfate above background were measured in two wells (DOE wells 723 and 732), above background for manganese in DOE well 111, above background for molybdenum in DOE well 732, and above background for sulfate in several wells (DOE wells 705, 717, 719, and 735). The concentration of molybdenum (except in DOE well 732) and uranium were never measured above background.

The mechanism by which the contaminants of concern may have migrated into the intermediate semiconfined bedrock aquifer is also not clear. It is suggested that more frequent measurements on a quarterly to monthly basis for one year be done for groundwater elevations, field properties, major ions and silica, and total and dissolved manganese, molybdenum, sulfate, and uranium in DOE wells 101 and 111, 706 and 735, 716 and 717,718 and 719,722R and 723, and 784 and 732 . Analysis of $\delta^{18} \mathrm{O}_{\text {sulfate }}$ and $\delta^{34} \mathrm{~S}_{\text {sulfate }}$ in samples collected from the following nested DOE wells could help determine the source of sulfate in the intermediate semiconfined bedrock aquifer: 724,725 , and $726 ; 101,111$, and 110; 784 and $732 ; 716$ and $717 ; 722 \mathrm{R}$ and $723 ; 707,705$, and $709 ; 706$ and $735 ; 718$ and $719 ; 729$ and 730; 720 and 721 ; and 733 and 734 .

The degree of the hydraulic connection between the Little Wind River and the upper unconfined alluvial aquifer and the intermediate semiconfined bedrock aquifer on both sides of the river needs to be determined. Water-quality data collected from the intermediate semiconfined bedrock aquifer on both sides of the river and from the upper unconfined alluvial aquifer on the south side of the river is very limited. The available water-elevation data indicate that (1) there is a consistent hydraulic gradient from the upper unconfined alluvial aquifer down into the intermediate semiconfined bedrock aquifer on both sides of the river, (2) there is a prevalent hydraulic gradient from the lower confined bedrock aquifer up into the intermediate semiconfined bedrock aquifer on both sides of the river, and (3) the hydraulic gradient in the upper unconfined alluvial aquifer on the north side of the river is from northwest to southeast but reverses in the flood plain of the river during high flows associated with snowmelt runoff, and (4) the hydraulic gradient in the intermediate semiconfined bedrock aquifer in the vicinity of the Little Wind River is from the northwest to the southeast but also reverses during high flows associated with snowmelt runoff. It is not known how much of the groundwater in either the upper unconfined alluvial aquifer or the intermediate semiconfined bedrock aquifer is flowing beneath or into the river under either flow condition. It is suggested that more frequent measurements on a quarterly to monthly basis for one year be done for groundwater elevations, field properties, major ions and silica, and total and dissolved manganese, molybdenum, sulfate, and uranium in DOE wells $702,706,707,709,735,788,789$, and 809 .

The comparison of groundwater elevations, major ion chemistry, and the median concentrations of manganese, molybdenum, sulfate, and uranium in 11 groups of nested DOE monitoring wells, and a principal component analysis (PCA) yielded similar conclusions which are (1) there is no evidence of contamination in the lower confined bedrock aquifer, (2) there is evidence of contamination in the intermediate semiconfined bedrock aquifer at a few locations, mainly at DOE wells 723 and 732, (3) contaminated groundwater is discharging into Oxbow Lake, and (4) the increased concentrations of contaminants of concern measured in several DOE wells following the flooding of the Little Wind River in June 2010 most likely are a result of the increase in the groundwater table dissolving or desorbing contaminants that were deposited in the upper soil layers during previous high-water elevations in the 1990s. The comparison of groundwater elevations, major ion chemistry, and the median concentrations of manganese, molybdenum, sulfate, and uranium in 11 groups of nested DOE monitoring wells also indicated that wells other than 723 and 732 had evidence of contamination, but the PCA analysis did not. These were DOE wells 111 (on the basis of high concentrations of manganese only), and 705, 717,719 , and 735 (on the basis of high concentrations of sulfate only). Why the PCA did not identify these wells as being contaminated is not known; perhaps the high concentration of sulfate in these wells is from natural sources.

The current monitoring network appears to be adequate to determine the effectiveness of natural attenuation for the contaminants of concern because the horizontal extent of the occurrences of above-background concentrations of arsenic, manganese, molybdenum, sulfate, and uranium has been adequately delineated in all three aquifers. Data for boron, iron, lead, selenium, and vanadium were extremely limited but indicate that they are present at background concentrations throughout each aquifer. The overall distribution of arsenic, manganese, molybdenum, nickel, sulfate, and uranium in the upper unconfined alluvial aquifer lies within an area between DOE well 718 on the west, on the east between DOE well 722R and DOE well 729, and from DOE well 101 on the northwest trending southeast through Oxbow Lake down to the Little Wind River.

Data to evaluate the influence of water in the Koch drainage ditch on the Little Wind River were limited. The 
available data indicate that the water in the Koch drainage ditch is affecting only the concentration of sulfate, to any measurable degree, only in West Side Creek, and sulfate in West Side Creek appears to be diluted as it flows into the Little Wind River. A quantitative assessment of the influence of the Koch drainage ditch on West Side Creek and the influence of West Side Creek on the Little Wind River is needed and might be accomplished by collecting waterquality samples and measuring discharge concurrently from the Koch drainage ditch, site 741, site 822, and in the Little Wind River upstream and downstream from the confluence with West Side Creek. The discharge measurements will allow for mass balance calculations that can quantify the amount of dilution occurring in West Side Creek and the Little Wind River.

\section{References Cited}

Christie, O.H.J., Esbensen, K., Meyer, T., and Wold, S., 1984, Aspects of pattern recognition in organic geochemistry: Organic Geochemistry, v. 6, p. 885-891.

Daddow, R.L., 1996, Water resources of the Wind River Indian Reservation, Wyoming: U.S. Geological Survey WaterResources Investigations Report 95-4223, 121 p.

Drever, J.I., 1988, The geochemistry of natural waters (2d ed.): Englewood Cliffs, N.J., Prentice Hall, 437 p.

Duewer, D.L., Kowalski, B.R., and Schatzki, T.F., 1975, Source identification of oil spills by pattern recognition analysis of natural elemental composition: Analytical Chemistry, v. 47, p. 1573-1583.

Frankenberger, W.T., Jr., ed., 2002, Environmental chemistry of arsenic: N.Y., Marcel Dekker, Inc., 391 p.

Freeze, R.A., and Cherry, J.A., 1979, Groundwater: Englewood Cliffs, N.J., Prentice Hall, 604 p.

Helsel, D.R., and Hirsch, R.M., 1992, Statistical methods in water resources: New York, Elsevier, 522 p.

Hem, J.D., 1985, Study and interpretation of the chemical characteristics of natural water: U.S. Geological Survey Water-Supply Paper 2254, 263 p.

Heydorn, K., and Thuesen, I., 1989, Classification of ancient Mesopotamian ceramics and clay using SIMCA for supervised pattern recognition: Chemometrics and Intelligent Laboratory Systems, v. 7, p. 181-188.

Infometrix, 2010, Comprehensive chemometrics modeling software: Infometrix Web site, accessed June 27, 2010, at http://infometrix.com/software/pirouette.html.
MacCarthy, P., DeLuca, S.J., Voorhees, K.J., Malcolm, R.L., and Thurman, E.M., 1985, Pyrolysis-mass spectrometry/ pattern recognition on a well-characterized suite of humic samples: Geochimica et Cosmochimica Acta, v. 49, p. 2091-2096.

McGreevy, L.J., Hodson, W.G., and Rucker, S.J., IV, 1969, Ground-water resources of the Wind River Indian Reservation Wyoming: U.S. Geological Survey WaterSupply Paper 1576-I, 145 p.

Meglen, R.R., and Erickson, G.A., 1983, Application of pattern recognition to the evaluation of contamination from oil shale retorting, in Francis, C.W., and Auerbach, S.I., eds., Environment and solid wastes - Characterization, treatment, and disposal: Boston, Mass., Butterworths, p. 369-381.

Mello, E., Monna, D., and Oddone, M., 1988, Discriminating sources of Mediterranean marbles - A pattern recognition approach: Archaeometry, v. 30, p. 102-108.

Naftz, D.L., 1996a, Pattern recognition analysis and classification modeling of selenium-producing areas: Journal of Chemometrics, v. 10, p. 309-324.

Naftz, D.L., 1996b, Using geochemical and statistical tools to identify irrigated areas that might contain high selenium concentrations in surface water: U.S. Geological Survey Fact Sheet FS-077-96, 4 p.

Naftz, D.L., Ranalli, A.J., Rowland, R.C., and Marston, T.M., 2011, Assessment of potential migration of radionuclides and trace elements from the White Mesa uranium mill to the Ute Mountain Ute Reservation and surrounding areas, southeastern Utah: U.S. Geological Survey Scientific Investigations Report 2011-5231, 146 p.

Parkhurst, D.A., and Appelo, C.A.J., 2010, User's guide to PHREEQC (Version 2)-A computer program for speciation, batch-reaction, one-dimensional transport, and inverse geochemical calculations: U.S. Geological Survey Web site accessed September 22, 2010, at http://wwwbrr. cr.usgs.gov/projects/GWC_coupled/phreeqc/html/final.html.

Sherman, H.M., Gierke, J.S., and Anderson, C.P., 2007, Controls on spatial variability of uranium in sandstone aquifers: Ground Water Monitoring and Remediation, v. 27, no. 2, p. 106-118.

Smith, D.B., and Sweat, M.J., 2012, Reconnaissance soil geochemistry at the Riverton Uranium Mill Tailings Remedial Action Site, Fremont County, Wyoming: U.S. Geological Survey Open-File Report 2012-1257, 23 p.

U.S. Department of Energy, 1995, Baseline risk assessment of ground water contamination at the uranium mill tailings site near Riverton, Wyoming: U.S. Department of Energy DOE/ AL/62350-65 rev. 1, ver. 2, 166 p. 
U.S. Department of Energy, 1998, Final site operational work plan for the UMTRA project site at Riverton, Wyoming: U.S. Department of Engergy Web site, variously paged, www.lm.doe.gov/Riverton/RVT00000133.pdf.

U.S. Department of Energy, 2001, Site observational work plan for the Naturita, Colorado, UMTRA project site: Grand Junction, Colo., U.S. Department of Energy, DOE contract no. DE-AC13-96GJ87335, 10 p.

U.S. Department of Energy, 2009, U.S. Department of Energy's legacy management program: U.S. Department of Energy Web site, accessed February 16, 2012, at http:// www.lm.doe.gov/WorkArea/linkit.aspx?LinkIdentifier $=i d \& I$ temID $=6636$.

U.S. Department of Energy, 2012, Geospatial environmental mapping system: U.S. Department of Energy Web site, accessed February 17, 2012, at http://gems.lm.doe.gov/imf/ ext/gems/jsp/launch.jsp?verify=true\&popup_blocked=true.

U.S. Geological Survey, 2013, National Water Information System: U.S. Geological Survey Web site, accessed December 16, 2013, at URL http://waterdata.usgs.gov/wy/ nwis/sw/.

Voorhees, K.J., and Tsao, R., 1985, Smoke aerosol analysis by pyrolysis-mass spectrometry-Pattern recognition for assessment of fuels involved in flaming combustion: Analytical Chemistry, v. 57, p. 1630-1636.

White, A.F., Delany, J.M., Narasimhan, T.N., and Smith, A., 1984, Groundwater contamination from an inactive uranium mill tailings pile-I. Application of a chemical mixing model: Water Resources Research, v. 20, no. 11, p. $1743-1752$.

Zielinski, R.A., Chafin, D.T., Banta, E.R., and Szabo, B.J., 1997, Use of ${ }^{234} U$ and ${ }^{238} U$ isotopes to evaluate contamination of near-surface groundwater with uraniummill effluent-A case study in south-central Colorado, U.S.A: Environmental Geology, v. 32, no. 2, p. 124-136.
Publishing support provided by:

Denver Publishing Service Center

For more information concerning this publication, contact: Director, USGS Colorado Water Science Center Box 25046, Mail Stop 415

Denver, CO 80225

(303) 236-4882

Or visit the Colorado Water Science Center Web site at: http://co.water.usgs.gov/ 


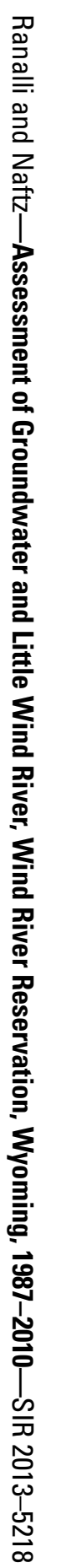

